
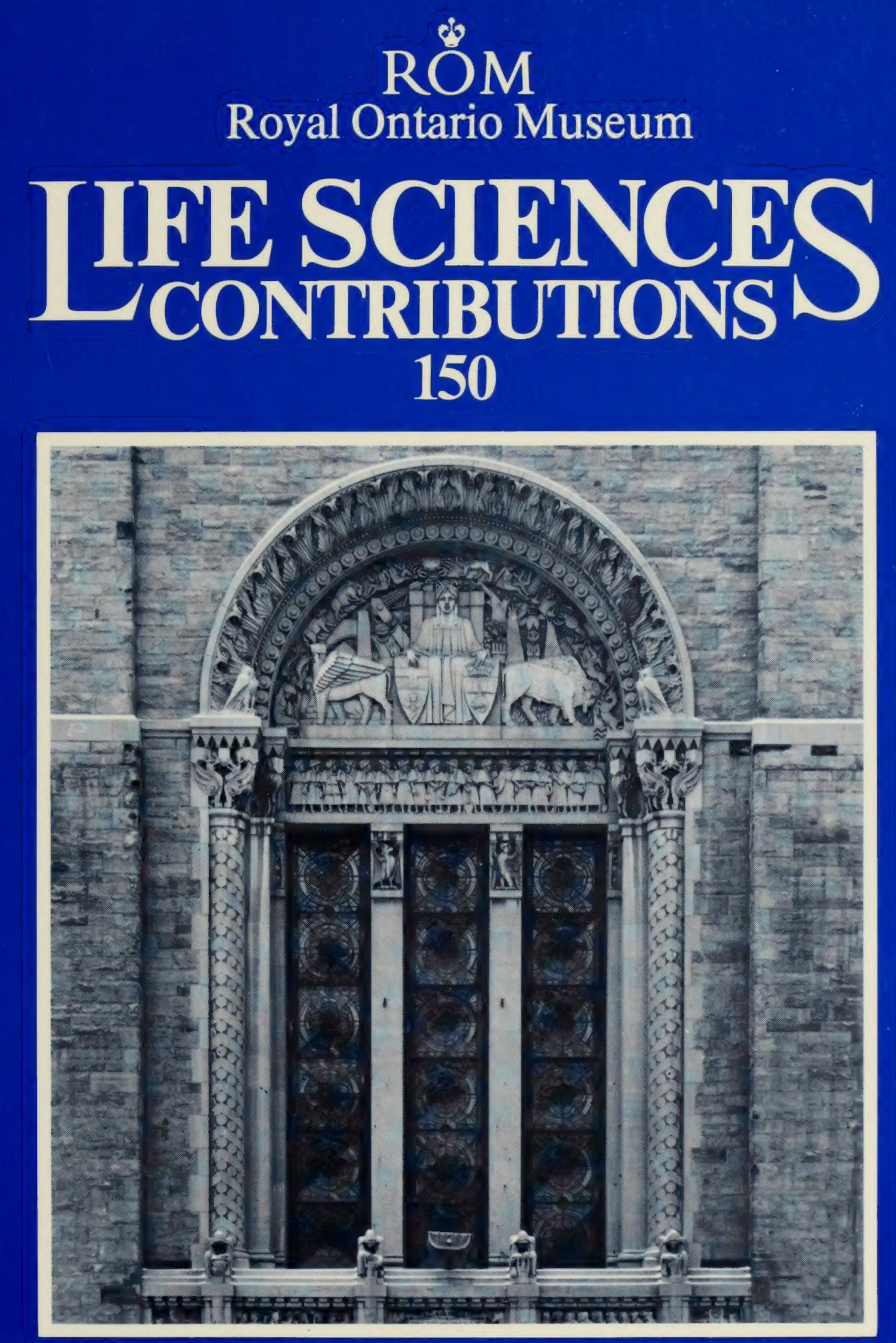

Late Cretaceous-Early Tertiary Dinoflagellates and Acritarchs from the Kashi Area, Tarim Basin, Xinjiang Province, China

Mao Shaozhi and Geoffrey Norris 


\section{ROYAL ONTARIO MUSEUM LIFE SCIENCES PUBLICATIONS INSTRUCTIONS TO AUTHORS}

Authors should prepare their manuscripts carefully according to the following instructions; failure to do so will result in the manuscript's being returned to the author for revision. All manuscripts are considered on the understanding that they are not currently offered for publication elsewhere.

1. General Papers for publication are accepted from ROM staff members and research associates, and from researchers reporting on work done with ROM collections. Monographs on the flora and/or fauna of Ontario may be considered for publication by authors not affiliated with the ROM. Financial contributions towards publication will be welcome. Authors are expected to write clearly and concisely and to omit any material not essential for an understanding of the main theme of the paper.

2. Format Manuscripts (including captions, synonymies, literature cited, and tables) should be typed with double space on 11 ' $\times 8 \frac{1}{2}$ " ' paper with a $1 \frac{112}{2}$, margin on all sides. Three xerox copies should be submitted to the Senior Editor of the Editorial Board; the original should be retained by the author(s). The submission should include a separate sheet giving the author(s) names and affiliations, the title of the publication, the series for which it is submitted, the number of typed pages, the number of tables, and the number of plates or figures. Manuscripts should normally be organized in the following order: Contents, Abstract, Introduction, Materials and Methods, Results, Discussion, Conclusions, Summary (if manuscript is long), Acknowledgements, Appendices, and Literature Cited. Authors are encouraged to include foreign-language translations of the Summary, if appropriate. Main headings should be centred; subheadings should be left-justified to the text margin. The first line of the first paragraph in each new section should not be indented. Literature citations in the text should be in the form "Jones (1972)" or "(Jones, 1972)" or "(Smith, 1960:71-79, fig. 17)".

3. Standard Sources The primary authority on questions of format and style is Guide to Authors, available from ROM Publication Services. For matters not covered in the Guide, consult CBE Style Manual (Fifth Edition). Other standard sources are as follows: for
English spelling, The Concise Oxford Dictionary; for Canadian place names and coordinates, Canada Gazetteer Atlas; for the spelling of geographic names, The Times Atlas.

4. Abstract All papers must be preceded by a short, factual abstract, about one per cent of the text in length. The abstract may be followed by four to six key words in parentheses.

5. Taxonomy The name of a taxon should be given in full in headings, at the beginnings of paragraphs, and at its first occurrence in the text. Give the authority and date, if appropriate, with the first mention of each taxon, but not thereafter. Taxonomic papers, particularly synonymies, should follow the layout in Life Sciences Contributions beginning with No. 136. International Codes of Biological Nomenclature must be followed.

6. Literature Cited A complete list of references, in alphabetical order of authors, must be given at the end of the paper. When two or more works of one author are cited, they should be listed chronologically. The names of journals should not be abbreviated. For correct bibliographic form, see Life Sciences Contributions beginning with No. 136.

7. Tables All tables should be typed on separate sheets and numbered consecutively in arabic numerals in the order of their first mention in the text. Mark the location of each table in the margin of the text.

8. Plates, Figures, and Text-figures Illustrations may be designated according to the conventions of the author's discipline; in some disciplines grouped photographs of scientific subject matter are commonly termed Plates, while line drawings and locality and other illustrations that occupy a full page or less are Text-figures. Usage must be consistent throughout the paper. A full-page illustration for a Contribution, with its caption, should be sized to fit an area of $17.3 \times$ $22.75 \mathrm{~cm}$; for Occasional Papers, the area is $14.1 \times$ $21.2 \mathrm{~cm}$. If captions are lengthy, they may be placed on the facing page. A scale or magnification factor should be included. Authors are reminded that when illustrations are reduced magnification factors will change, and that they are responsible for the conversion. For details, see Guide to Authors. 


\section{Late Cretaceous - Early Tertiary Dinoflagellates and Acritarchs from the Kashi Area, Tarim Basin, Xinjiang Province, China}


Digitized by the Internet Archive in 2011 with funding from University of Toronto 
LIFE SCIENCES CONTRIBUTIONS 150

\section{Late Cretaceous-Early Tertiary Dinoflagellates and Acritarchs from the Kashi Area, Tarim Basin, Xinjiang Province, China}

Mao Shaozhi and Geoffrey Norris 


\section{ROYAL ONTARIO MUSEUM \\ PUBLICATIONS IN LIFE SCIENCES}

The Royal Ontario Museum publishes three series in the Life Sciences:

CONTRIBUTIONS: a numbered series of original scientific publications.

OCCASIONAL PAPERS: a numbered series of original scientific publications, primarily short and of taxonomic significance.

MISCELLANEOUS PUBLICATIONS: an unnumbered series on a variety of subjects.

All manuscripts considered for publication are subject to the scrutiny and editorial policies of the Life Sciences Editorial Board, and to independent refereeing by two or more persons, other than Museum staff, who are authorities in the particular field involved.

\section{LIFE SCIENCES EDITORIAL BOARD}

Senior Editor: J. L. Eger

Editor: D. C. Darling

Editor: R. W. Murphy

External Editor: C.S. Churcher

Manuscript Editor: D. R. Calder

Production Editor: B. E. Ibronyi

Mao Shaozhi is professor of geology in The Chinese University of Geosciences (Beijing).

Geoffrey Norris is professor in the Department of Geology, University of Toronto, and research associate in the Department of Botany, Royal Ontario Museum.

\footnotetext{
Canadian Cataloguing in Publication Data

Mao, Shaozhi, 1936-

Late Cretaceous-early Tertiary dinoflagellates and acritarchs from the Kashi area, Tarim Basin, Xinjiang Province, China

(Life sciences contributions, ISSN 0384-8159;150)

Bibliography: $\mathrm{p}$.

ISBN 0-88854-334-4

1. Dinoflagellata, Fossil. 2. Acritarchs.

3. Paleontology - Cretaceous. 4. Paleontology -

Tertiary. 5. Paleontology - China. I. Norris, G.

(Geoffrey), 1937- . II. Royal Ontaro Museum.

III. Title. IV. Series.
}

QE774.D5M36 $1988 \quad 563^{\prime} .18 \quad$ C $88-094301-7$

Publication Date: 17 October 1988

ISBN 0-88854-334-4

ISSN 0384-8159

(C) Royal Ontario Museum, 1988

100 Queen's Park, Toronto, Ontario, M5S 2 C6

PRINTED AND BOUND IN CANADA AT THE ALGER PRESS 


\section{Contents}

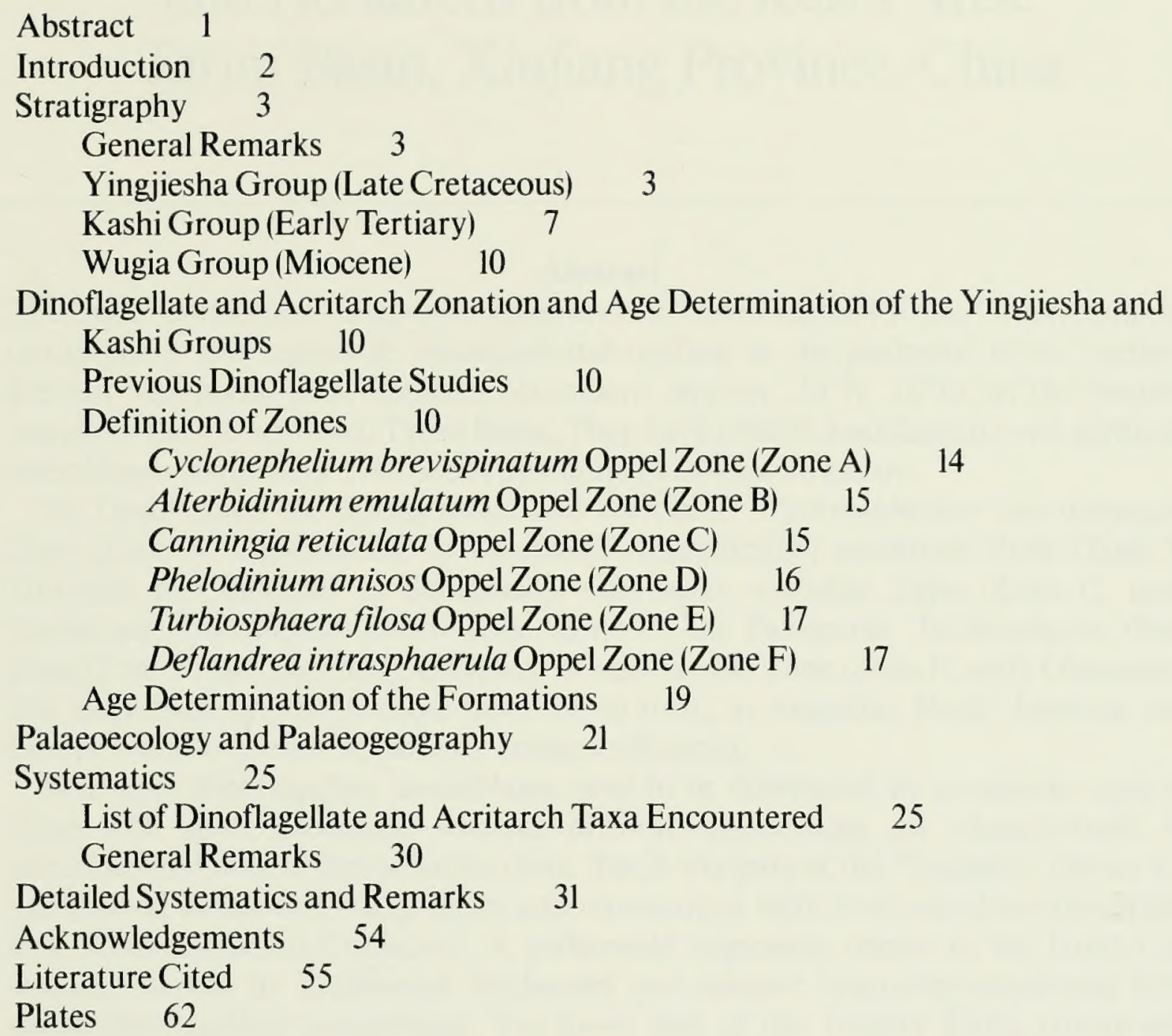





\title{
Late Cretaceous - Early Tertiary Dinoflagellates and Acritarchs from the Kashi Area, Tarim Basin, Xinjiang Province, China
}

\begin{abstract}
The Upper Cretaceous Yingjiesha Group and the Lower Tertiary Kashi Group comprise transgressive and regressive sequences and outcrop in the piedmont of the western Kunlun Mountains and Tianshan Mountains (approx. $39^{\circ} \mathrm{N}, 76^{\circ} \mathrm{E}$ ) on the western margin of the intracratonic Tarim Basin. They have yielded dinoflagellate and acritarch assemblages comprising 176 species distributed amongst 82 genera.

Six Oppel zones are distinguished and correlated: Cyclonephelium brevispinatum Zone (Zone A; Cenomanian to Turonian), Alterbidinium emulatum Zone (Zone B; Turonian to Coniacian or Santonian), Canningia reticulata Zone (Zone C; postConiacian), Phelodinium anisos Zone (Zone D; late Paleocene), Turbiosphaera filosa Zone (Zone E; late Eocene), Deflandrea intrasphaerula Zone (Zone F; early Oligocene). The assemblages resemble those from coeval strata in Australia, North America, and Europe but also contain apparently endemic elements.

Nearshore dinoflagellate assemblages tend to be dominated by proximate cysts or those with short processes, whereas offshore assemblages are characterized by numerous and diverse skolochorate cysts. The lower part of the Yingjiesha Group is a fine-grained clastic and shelly facies and represents a shift from nearshore conditions from Cenomanian to Coniacian. A widespread regression occurs in the latest Cretaceous, marked by gypsiferous mudstones and massive evaporites containing only sparse dinoflagellate assemblages. The lower part of the Tertiary Kashi Group also exhibits gypsiferous sediments and sparse but distinctive dinoflagellate floras. A major transgression is recorded in the middle to upper Paleocene Qimugen Formation and another in the upper Eocene Wulagen Formation, with diverse and abundant skolochorate dinocysts accompanying calcareous perforate foraminifera in grey and green mudstones, marls, and shelly limestones. The intervening regressive intervals are generally characterized by gypsiferous mudstones, massive gypsum, dolostones, reddish mudstones with calcareous perforate and sparse agglutinating foraminifera, and a few poorly preserved dinocysts, acritarchs, and terrestrial angiosperm pollen. The following new taxa are described: Alterbidinium emulatum sp. nov., Batiacasphaera hystrieosa sp. nov., Ceratiopsis speciosa subsp. elongata subsp. nov., Canningia kukebaiensis sp. nov., Cerbia formosa sp. nov., Cleistosphaeridium radiculopsis sp. nov., Deflandrea intrasphaerula sp. nov., D. musculopsis sp. nov., Eurydinium tempestivum sp. nov., Florentinia laciniata subsp. propria nov., Kisselovia fusiformis sp. nov., K. wulagenensis sp. nov., Millioudodinium (?) aequum sp. nov., M. (?) venulosum sp. nov., Palaeohystrichophora granulata sp. nov., Phelodinium anisos sp. nov., Pseudoalterbia concinna sp. nov., Sentusidinium stipulatum sp. nov., Talimudinium scissurum gen. et sp. nov., Trithyrodinium sabulum sp. nov., Wetzeliella crassa sp. nov., Xuidinium laevigatum gen. et sp. nov., and one new combination, Coronifera minor (Yu and Zhang).
\end{abstract}




\section{Introduction}

Fossil dinoflagellates were first observed by Ehrenberg $(1836,1837)$ in upper Cretaceous sediments of Germany and have been studied intensively for the past two decades in North America, Australia, and Europe (Sarjeant, 1974). Little attention had been given to them in China until Sung et al. (1978) described Paleogene dinoflagellates and acritarchs from the coastal region of Bohai, China. More than 100 new taxa were described in that paper; however, the majority of those may be acritarchs rather than dinoflagellates. Since then a few publications have appeared in China dealing with dinoflagellates and acritarchs. Because of poor communi- cations between Chinese palynologists and palynologists outside China, compounded by the paucity of literature available in China, some of the taxonomy and terminology used in those papers are unfortunately either incorrect or out of date.

The purpose of the present paper is to investigate the palynostratigraphy, taxonomy, and palaeoecology of dinoflagellate and acritarch assemblages from the Upper Cretaceous to Lower Tertiary strata of the Tarim Basin (Text-Fig. 1).

Abundant dinoflagellate cysts have been found in the Upper Cretaceous and Lower Tertiary of the western

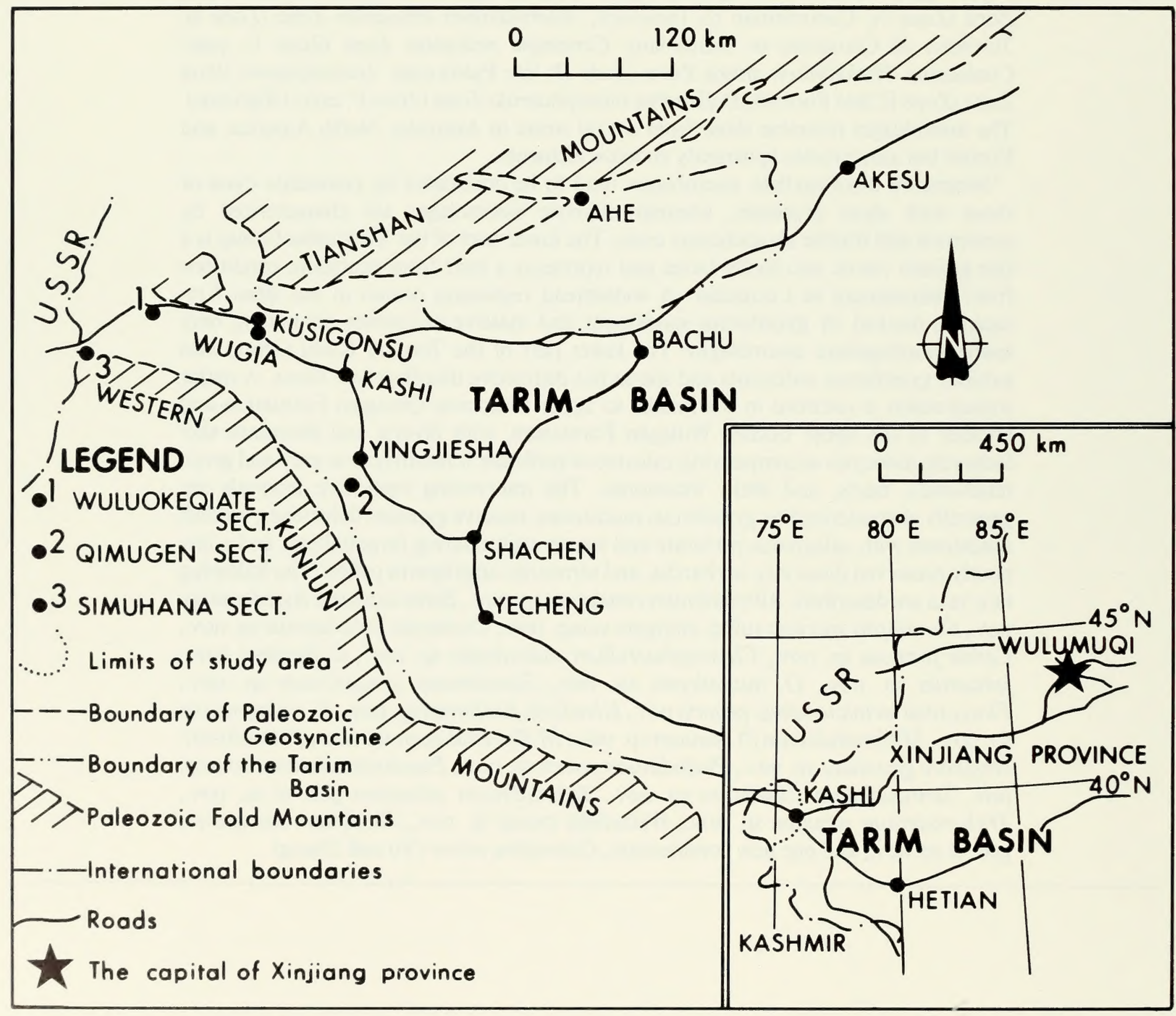

TEXT-FIG. 1. Map showing the locations of study area in the Tarim Basin. Sections studied are numbered $1,2,3$. 
margin of the Tarim Basin by the present authors (Mao and Norris, 1984) and by Yu and Zhang (1980). Previous micropalaeontological work in the basin includes one paper on upper Cretaceous dinoflagellates ( $\mathrm{Yu}$ and Zhang, 1980), two papers on pollen and spores of the upper Cretaceous $(\mathrm{Yu}, 1981)$ and the lower Tertiary (Zhao, Sun, and Wang, 1981) respectively, and three papers on upper Cretaceous and Tertiary foraminifera (Hao and Zeng, 1980, 1981; Hao, Zeng, and Li, 1982).

The samples studied were collected from three sections in the Tarim Basin, these being the Wuluokeqiate, Qimugen, and Simuhana sections, located in the pied- mont of the Tianshan and western Kunlun mountains in the Kashi region of Xinjiang Province, China (Text-Fig. 1). The Simuhana section is a reference section, where samples were collected only from the uppermost Kukebai Formation to the lowermost Kalatar Formation.

In this paper, we adopt the romanized orthography for the "Tarim" Basin most commonly used in western geological literature and in the most recent comprehensive review in English of the geology of China (Yang, Cheng, and Wang, 1986). The alternative spelling used in some Chinese literature is "Talimu."

\section{Stratigraphy}

\section{GENERAL REMARKS}

The Tarim Basin is an intracratonic basin bounded on the north and south by Paleozoic fold belts. The basin subsided during the late Cretaceous and early Cenozoic. Mesozoic and Cenozoic strata unconformably overlie Paleozoic strata.

The Tarim Basin is developed over the Archean Tarim Craton of the Cathaysian Palaeoplate, which became sutured to the Angaraian Palaeoplate in the late Permian (Zhang, Liou, and Coleman, 1984). The basin is flanked to the north by the Tianshan Mountains and to the south by the western Kunlun Mountains (Text-Fig. 1). The northern mountain chain is part of the Tianshan-Tumen accretionary fold belt, which had a lengthy and complex Paleozoic history, recording subduction of the oceanic crust and accretion of volcanic chains from the Ordovician to the Permian, culminating in collision of the Angaraian and Tarim cratons in the late Permian along the Junggar-Hegen suture.

The western Kunlun Mountains to the south of the Tarim Basin are part of the Kunlun-Qinling accretionary fold belt, which also had a lengthy history of Paleozoic subduction and accretion of microcontinents. The western end of that belt is not well known but does record continuing deformation until the Triassic (Zhang, Liou, and Coleman, 1984).

By the end of the Triassic, the Chinese portion of the Eurasian Plate was considerably enlarged but continued to undergo deformation and accretion on the southwestern margin during the Jurassic and Cretaceous (early and late Yanshanian orogenies respectively). The Tarim Basin to the north of those orogenic belts was developed intracratonically and records several marine transgressions from the western Tethys from the mid-Cretaceous to the Oligocene (see Text-Figs. 6, 7). These transgressions were terminated in the Neogene by the spreading of the Miocene to Pliocene syntectonic molasse $1400 \mathrm{~km}$ northwards from the region of the Yarlung Zangbo-
Indus suture resulting from the collision between the Indian and Eurasian plates and the early development of the Himalayas.

Thus it would seem that the fold belts immediately north and south of the Tarim Basin were largely tectonically inactive during the Cretaceous and the Tertiary but probably had positive relief, to judge from stratigraphic and sedimentological evidence (in the next two sections). It is possible, however, that, with the introduction of a different stress field in western China, resulting from the strong collision between the Indian and Eurasian plates in the early Cenozoic, some rejuvenation and reactivation of earlier fold belts may have taken place (Zhang, Liou, and Coleman, 1984). The detailed biostratigraphic work reported herein may help to provide precision in the timing of these events.

Extensive transgressions occurred in the Tarim Basin during late Cretaceous to early Tertiary times (Yang, Cheng, and Wang, 1986) with the deposition of normal marine, nearshore, and lagoonal facies of the Upper Cretaceous Yingjiesha and Lower Tertiary Kashi groups (Text-Fig. 2). In contrast, the Lower Cretaceous Kezilesu Group is terrestrial, and the Upper Tertiary Wugia Group represents transitional marine and nonmarine strata.

The information in this stratigraphic section is derived mostly from Hao, Zeng, and Li (1982). Verification of the data as well as further details of stratigraphy may be found in that work.

\section{YINGJIESHA GROUP (LATE CRETACEOUS)}

The Yingjiesha Group is well exposed in the Tarim Basin and can be divided into four formations in ascending order as follows (Text-Figs. 2, 3).

Kukebai Formation $\left(K_{2} \mathbf{k}\right)$

Exposed discontinuously along the piedmont of the western Kunlun and Tianshan mountains, the Kukebai 
Formation is mainly composed of greyish green, brownish grey, and dark brown mudstones, intercalated with shell beds and shelly marls. Its base, however, embodies variegated dominantly brownish red mudstones. The formation is about 100 to $210 \mathrm{~m}$ thick and contains abundant bivalves, gastropods, ammonites, echinoderms, foraminifera, and ostracods, as well as dinoflagellates. It lies conformably on the Lower Cretaceous Kezilesu Group.

In the Wuluokeqiate section, the Kukebai Formation

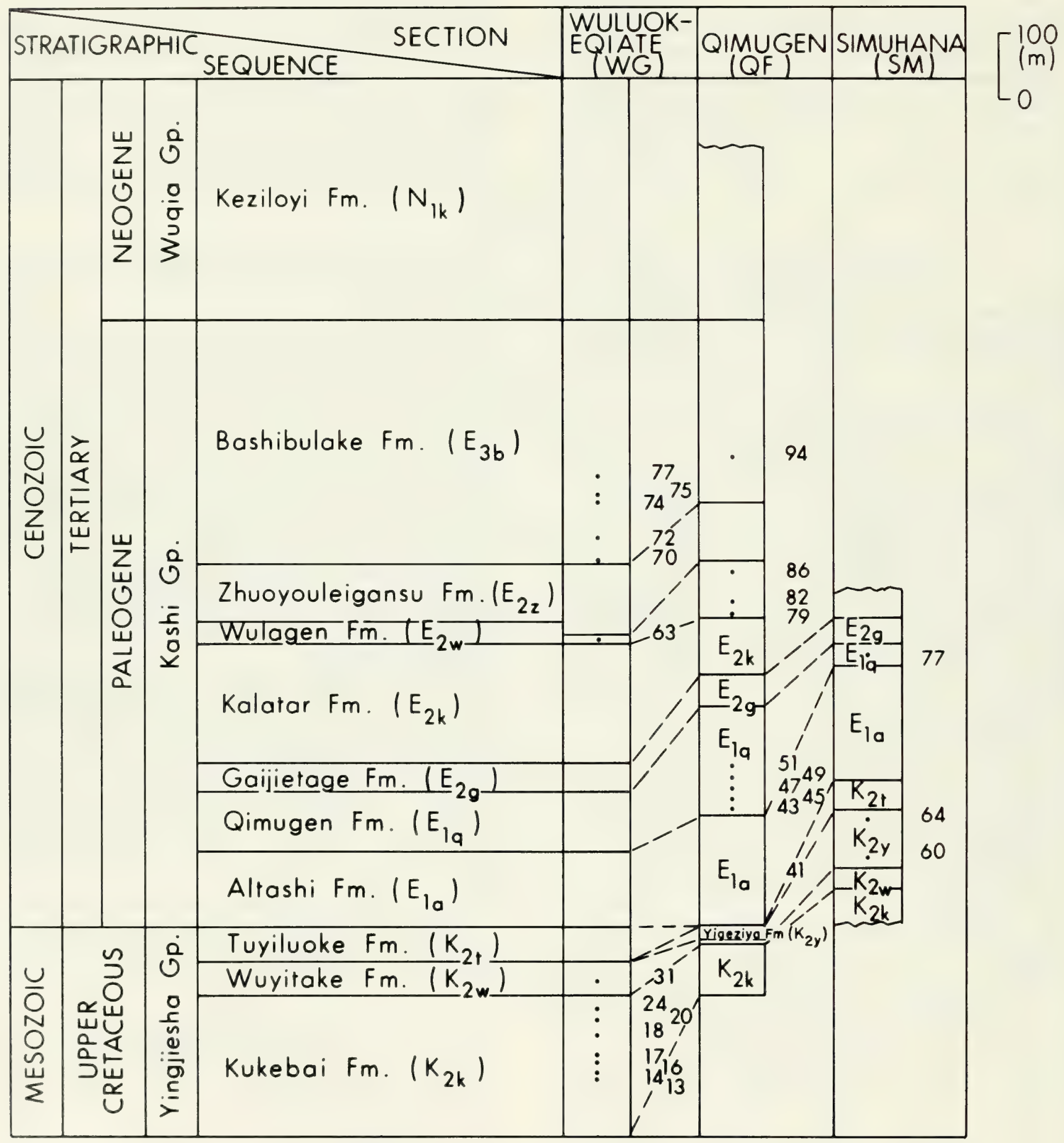

TEXT-FIG. 2. Positions of samples from three sections that yielded abundant dinoflagellate cysts. Sample positions in each section indicated by dots opposite sample numbers. In brackets are alphanumeric designations for the formations. 


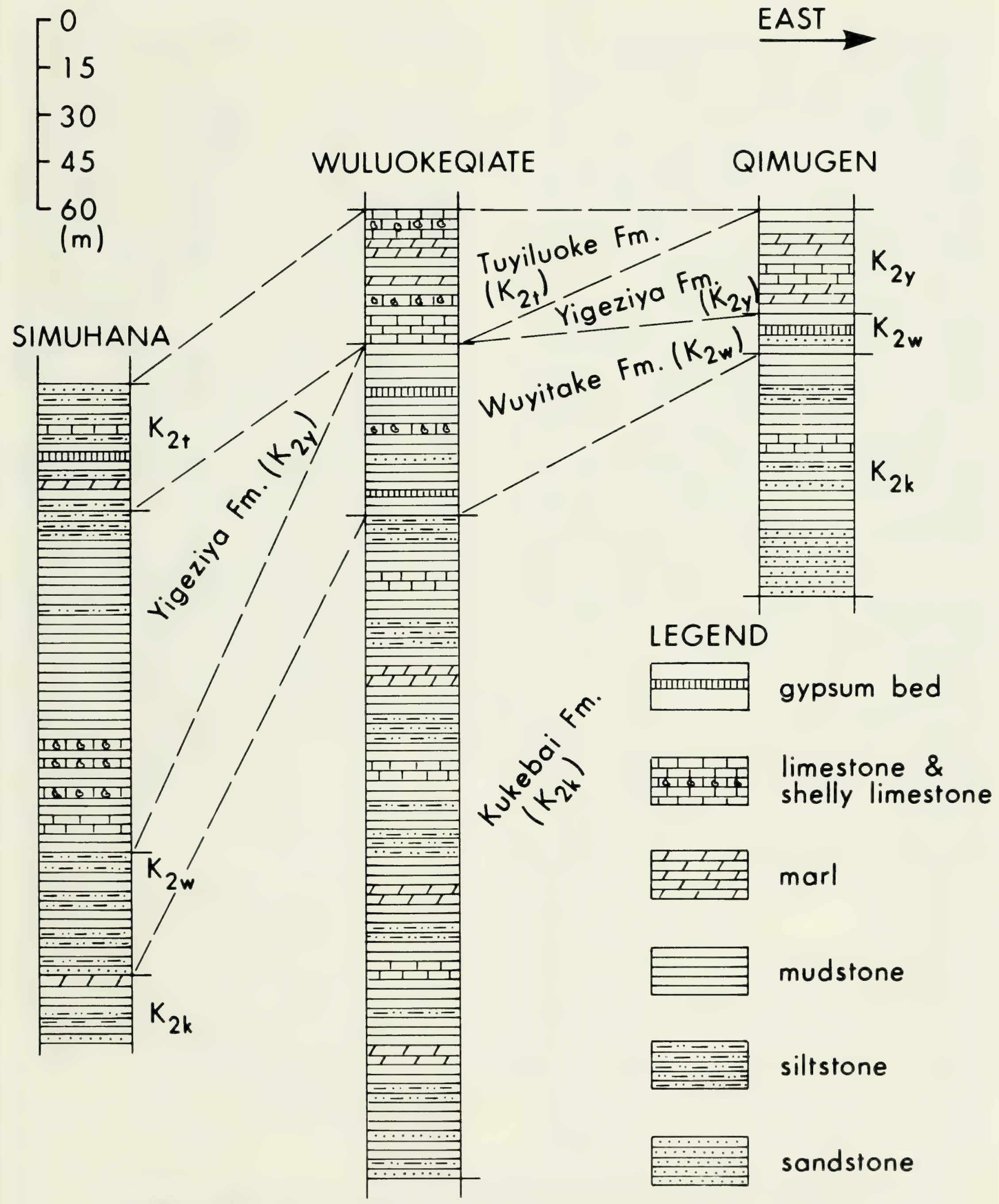

TEXT.FIG. 3. Upper Cretaceous lithostratigraphic correlations for the three sections sampled in the present study. Alphanumeric designations for the formations are the same as those in Text-Fig. 2. 
is $210 \mathrm{~m}$ thick; its lower part comprises brown mudstone and muddy sandstone intercalated with siltstone, but its bottom consists of yellowish grey and greyish green feldspathic-quartz fine-grained sandstones. The middle part of the formation consists of yellowish green, greyish green, and dark brown mudstones with intercalations of yellowish brown limestones, greyish yellow shell beds, and shelly marls. The upper part comprises greyish green and greyish yellow marls, mudstones, bioclastic limestones, and calcareous mudstones; horizontal stratification may be seen in the upper part. The total thickness of this section of the formation is about $200 \mathrm{~m}$.

In the Qimugen section, the Kukebai Formation comprises coarser clastics than in the Wuluokeqiate area; in the former it consists of medium- to fine-grained sandstones and muddy siltstones intercalated with mudstone and limestone and lacks shell beds in the upper part. It is reduced in thickness in this section to only $76 \mathrm{~m}$.

Of 19 samples macerated from the Kukebai Formation, 7 contain rich dinoflagellate and acritarch assemblages (Table 1).

\section{Wuyitake Formation $\left(K_{2} \mathbf{w}\right)$}

The Wuyitake Formation overlies the Kukebai Formation and outcrops discontinuously along the piedmont of both the western Kunlun and the Tianshan mountains. In the piedmont of the western Kunlun Mountains, it is 80 to $120 \mathrm{~m}$ thick and can be divided into three parts. The lower part consists of variegated gypsiferous mudstones interbedded with massive gypsum beds. The middle part comprises greyish green mudstones intercalated with limestones. The upper part is brownish red mudstone and gypsiferous mudstone intercalated with gypsum beds. In the piedmont of the Tianshan Mountains, the Wuyitake Formation is 133 to $200 \mathrm{~m}$ thick and comprises interbeddings of variegated mudstones, silty and gypsiferous mudstones, and muddy gypsum rocks, with intercalations of gypsum beds. In general this formation contains fewer fossils than does the Kukebai Formation; it does, however, contain bivalves, foraminifera, ostracods, and dinoflagellates.

In the Wuluokeqiate section, the Wuyitake Formation is $53 \mathrm{~m}$ thick and consists of brownish red and greyish

\begin{tabular}{|c|c|c|c|c|c|c|c|c|c|}
\hline \multirow[b]{3}{*}{ Formation } & \multicolumn{9}{|c|}{ Section } \\
\hline & \multicolumn{3}{|c|}{ Simuhana (SM) } & \multicolumn{3}{|c|}{ Wuluokeqiate (WG) } & \multicolumn{3}{|c|}{ Qimugen (QF) } \\
\hline & NT & N A\&S & N B\&I & NT & $\mathrm{N} A \& \mathrm{~S}$ & N B\&I & NT & N A\&S & N B\&I \\
\hline $\begin{array}{c}\text { Keziloyi } \\
\left(N_{1} k\right)\end{array}$ & 0 & 0 & 0 & 11 & 0 & 11 & 0 & 0 & 0 \\
\hline $\begin{array}{l}\text { Bashibulake } \\
\left(\mathrm{E}_{3} \mathrm{~b}\right)\end{array}$ & 0 & 0 & 0 & 16 & 5 & 11 & 8 & 1 & 7 \\
\hline $\begin{array}{l}\text { Zhuoyouleiganzu } \\
\left(\mathrm{E}_{2} \mathrm{z}\right)\end{array}$ & 0 & 0 & 0 & 0 & 0 & 0 & 0 & 0 & 0 \\
\hline $\begin{array}{l}\text { Wulagen } \\
\left(\mathrm{E}_{2} \mathrm{w}\right)\end{array}$ & 0 & 0 & 0 & 3 & 1 & 2 & 4 & 3 & 1 \\
\hline $\begin{array}{r}\text { Kalatar } \\
\left(\mathrm{E}_{2} \mathrm{k}\right)\end{array}$ & 1 & 0 & 1 & 5 & 0 & 5 & 3 & 0 & 3 \\
\hline $\begin{array}{l}\text { Gaijietage } \\
\qquad\left(E_{2} g\right)\end{array}$ & 6 & 0 & 6 & 1 & 0 & 1 & 3 & 0 & 3 \\
\hline $\begin{array}{l}\text { Qimugen } \\
\left(E_{1} g\right)\end{array}$ & 5 & 1 & 4 & 5 & 0 & 5 & 8 & 5 & 3 \\
\hline $\begin{array}{r}\text { Altashi } \\
\left(E_{\mid} a\right)\end{array}$ & 3 & 0 & 3 & 4 & 0 & 4 & 1 & 0 & 1 \\
\hline $\begin{array}{l}\text { Tuyiluoke } \\
\left(\mathrm{K}_{2} \mathrm{t}\right)\end{array}$ & 7 & 0 & 7 & 5 & 0 & 5 & 0 & 0 & 0 \\
\hline $\begin{array}{c}\text { Yigeziya } \\
\left(\mathrm{K}_{2} \mathrm{y}\right)\end{array}$ & 6 & 2 & 4 & 0 & 0 & 0 & 1 & 0 & 1 \\
\hline $\begin{array}{l}\text { Wuyitake } \\
\qquad\left(\mathrm{K}_{2} \mathrm{~W}\right)\end{array}$ & 4 & 0 & 4 & 5 & 1 & 4 & 0 & 0 & 0 \\
\hline $\begin{array}{c}\text { Kukebai } \\
\left(\mathrm{K}_{2} \mathrm{k}\right)\end{array}$ & 2 & 0 & 2 & 14 & 7 & 7 & 3 & 0 & 3 \\
\hline
\end{tabular}

TABLE 1. Numbers of samples and fossil abundance in different formations and sections.

$N T$, Total number of samples macerated. $N A \& S$, Number of samples that contain fossils abundant or sufficient to establish assemblages. $N B \& I$, Number of samples that contain almost no fossils or a few fossils insufficient to establish assemblages. 
green mudstones; silty mudstone intercalated with greyish white, greyish green, and light brown massive muddy gypsum beds; gypsiferous sandstones; and shales. No foraminifera have been found in these rocks.

In the Qimugen section, this formation is $16 \mathrm{~m}$ thick and comprises interbedded brownish red, greyish purple, and greyish brown gypsiferous mudstones and greyish green fine-grained sandstones, as well as muddy massive gypsum beds. As in the Wuluokeqiate section, no foraminifera have been found in the Qimugen section.

Nine samples were macerated from the Wuyitake Formation; of these, only one yielded abundant palynomorphs (Table 1).

\section{Yigeziya Formation $\left(K_{2} y\right)$}

In the piedmont of the western Kunlun Mountains, the Yigeziya Formation lies conformably on the Wuyitake Formation and is less extensive than the subjacent strata. It consists mainly of brownish red and grey limestones, shelly marl, and gypsiferous mudstones. Fossils are sparse in these sediments but include oysters, pectens, and rudistids, the last occasionally forming bioherms. The Yigeziya Formation reaches a maximum thickness of 120 to $130 \mathrm{~m}$; it becomes thinner in the piedmont of the Tianshan Mountains and is absent in the Wuluokeqiate area. In the Simuhana section the 35-m-thick Yigeziya Formation comprises dark grey and greyish green mudstones and brownish red gypsiferous siltstone.

In the Qimugen section, this formation is about $30 \mathrm{~m}$ thick and is composed of greyish white thin- to mediumbedded marls intercalated with brown silty mudstones and limestones. Gastropods and debris of other fossils occur at the top of this formation.

Seven samples were macerated from the Yigeziya Formation; two of these yielded abundant dinoflagellate cysts (Table 1).

\section{Tuyiluoke Formation $\left(\mathbf{K}_{2} \mathbf{t}\right)$}

The Tuyiluoke Formation has approximately the same distribution as the Yigeziya Formation along the piedmont of the Tianshan Mountains. Where present, it is conformable with underlying strata; it is absent, however, in the Qimugen area. It comprises brownish red mudstone and gypsiferous mudstone intercalated with gypsum or thin-bedded limestones. The formation is 40 to $60 \mathrm{~m}$ thick, containing no foraminifera.

Twelve samples were macerated; of these, four contain sparse, poorly preserved dinoflagellates, and all the others are barren (Table 1).

\section{KASHI GROUP (EARLY TERTIARY)}

The early Tertiary represents the best development of Mesozoic to Cenozoic marine deposition in the Tarim
Basin. During this time the depressions became a unified basin, in which the lithofacies of the Kashi Group are rather uniform, being chiefly composed of littoral lagoonal facies and shallow marine and tidal flat facies. The littoral lagoonal facies comprises gypsum beds and gypsiferous mudstones, whereas the other two are rhythmic units of limestones, shelly limestones, mudstones, and sandstones. The thickness of the Kashi Group may reach $1000 \mathrm{~m}$ but can be as little as $500 \mathrm{~m}$ in the piedmont of the western Kunlun Mountains.

The Kashi Group can be divided into seven formations, in ascending order as follows (Text-Figs. 2, 4).

\section{Altashi Formation $\left(E_{1} a\right)$}

The Altashi Formation is dominated by massive gypsum beds intercalated with gypsiferous mudstones and dolomitic limestones, containing poorly preserved small bivalves, gastropods, a few foraminifera, and dinoflagellates.

Lying disconformably on different parts of the underlying Upper Cretaceous, the Altashi Formation varies dramatically in thickness from 21 to $438 \mathrm{~m}$ : in the Simuhana section it is $171 \mathrm{~m}$ thick; in the Wuluokeqiate section, $110 \mathrm{~m}$ thick; and in the Qimugen section, $158 \mathrm{~m}$ thick.

In the Wuluokeqiate section, the formation consists of grey to greyish white massive gypsum beds intercalated with light grey and greyish yellow thin-bedded dolomitic limestones, with intercalations of brown gypsiferous mudstone at the base.

In the Qimugen area, the Altashi Formation is composed of greyish white massive gypsum beds with dark green gypsum stringers. The middle part of the formation here is intercalated with dark grey silty mudstone and thin-bedded dolostones.

Eight samples from the Altashi Formation were macerated; of these, three yielded few poorly preserved dinoflagellate and other palynomorphs.

\section{Qimugen Formation $\left(\mathbf{E}_{1} \mathbf{q}\right)$}

The Qimugen Formation conformably overlies the Altashi Formation. It is composed mainly of greyish green mudstone intercalated with thin-bedded shelly limestone. At its bottom a bed of grey limestone about 5 $\mathrm{m}$ thick is developed uniformly over the whole area. At the top a bed of grey and reddish grey massive limestones, 5 to $10 \mathrm{~m}$ thick, forms one of the marker beds in the area. The Qimugen Formation is usually about $100 \mathrm{~m}$ thick and contains abundant fossils of bivalves, gastropods, ostracods, foraminifera, dinoflagellates, and acritarchs.

In the Wuluokeqiate section, the Qimugen Formation is $92 \mathrm{~m}$ thick; its lower part consists of greenish yellow and yellowish grey thick-bedded feldspathic-quartz sandstone. The middle part comprises brownish grey thick- 


\section{LEGEND}

gypsum beds

limestone \& WULUOKEQIATE

shelly limestone

臣, marl

Eudstone

siltstone

$\because \because \because$ sandstone

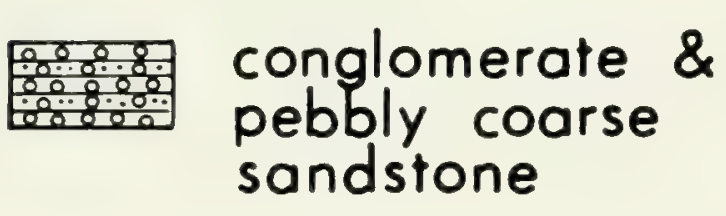

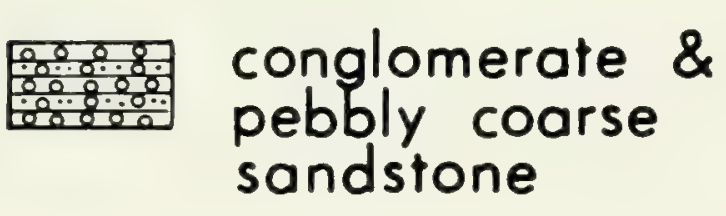

conglomerate \&
pebbly coarse
sandstone
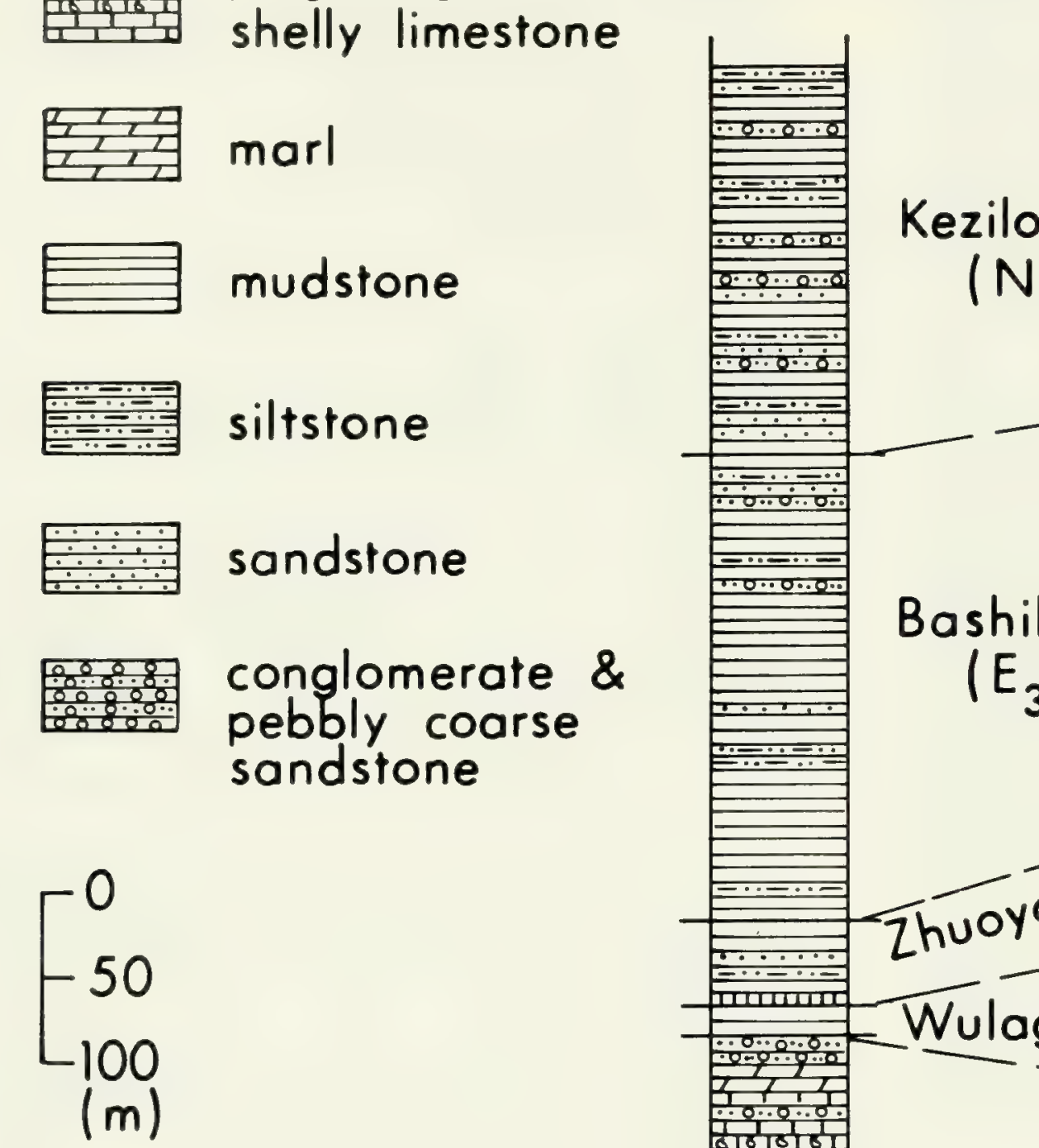

Keziloyi $\mathrm{Fm}$.

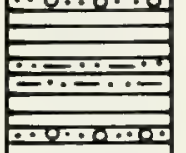

mudstone

siltstone

.

$\left(N_{l k}\right)$

QIMUGEN
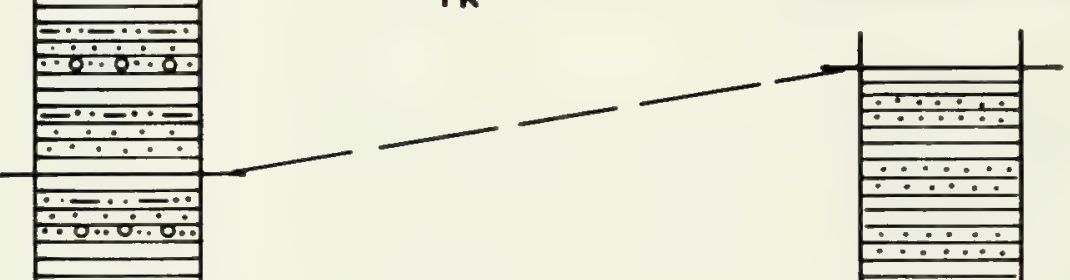

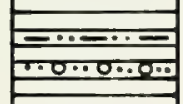

Bashibulake Fm.

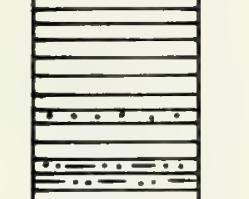

$\left(E_{3 b}\right)$

$E_{3 b}$

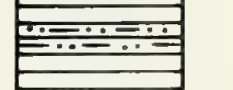

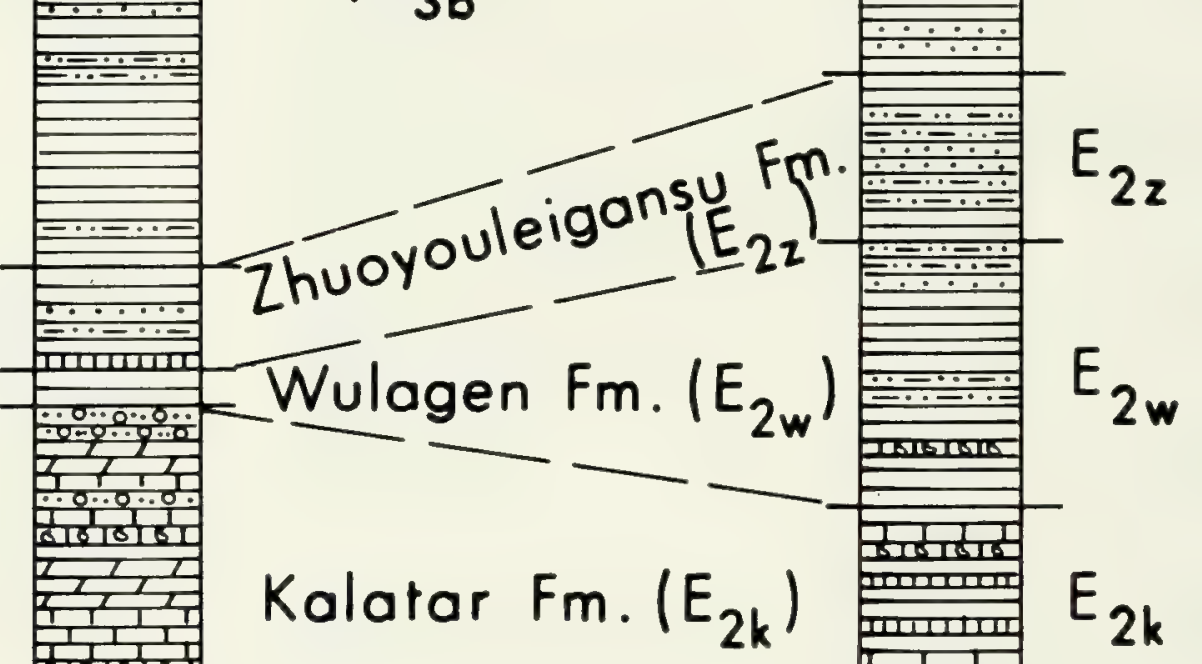

Zhuoyouleigan $E_{22} \ldots$

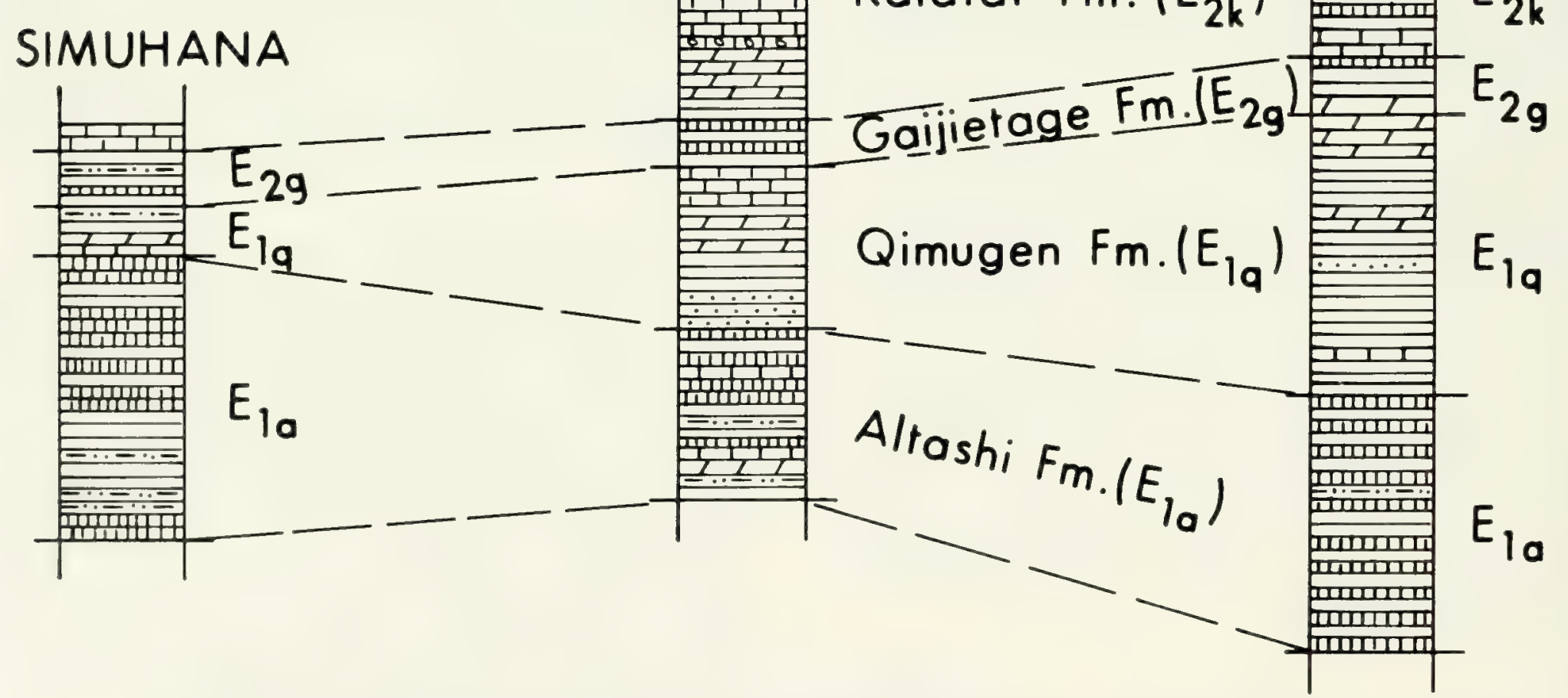

TEXT.FIG. 4. Lower Tertiary lithostratigraphic correlations for the three sections sampled in the present study. Alphanumeric designations for the formations are the same as those in Text-Fig. 2. 
bedded shelly marl and dark brown and greyish green mudstone, and the upper part comprises greyish white massive limestones. Abundant foraminifera including both calcareous perforate and agglutinating forms have been found here; however, almost no dinoflagellates have been obtained yet.

In the Qimugen section, the lower and middle parts of the Qimugen Formation are composed of dark grey mudstone, with intercalations of shelly and sandy mudstone, with yellowish grey shelly and sandy limestone at the bottom of the lower part. The upper part consists of dark grey marl interbedded with purplish grey, yellowish green, and variegated mudstones. The section is $16 \mathrm{~m}$ thick. No pelagic foraminifera have been found, and dinoflagellates are present. Of 18 samples, only 6 contain abundant dinoflagellates (Table 1).

\section{Gaijietage Formation $\left(\mathbf{E}_{2} \mathbf{g}\right)$}

The Gaijietage Formation conformably overlies the Qimugen Formation and is usually 30 to $50 \mathrm{~m}$ thick. It comprises brown gypsiferous mudstones and muddy massive gypsum beds intercalated with yellowish green mudstone. This unit, which used to be the upper member of original Qimugen Formation, is lithologically distinct from the lower member of that formation. Hao, Zeng, and $\mathrm{Li}$ (1982) restricted the Qimugen Formation to include only that part previously referred to as the lower member of the original Qimugen Formation; they named a new unit, the Gaijietage Formation, to encompass those strata previously referred to as the upper member of the original Qimugen Formation, because they noted that the characteristics and diagnostic elements of the Lower Nonion-Cibicides assemblage found in Kuzigonsu section (Text-Fig. 1) from the newly named Gaijietage Formation and overlying Kalatar Formation are more closely related to those of the Nonion-AnomalinoidesCibicides assemblage (Eocene) from the Wulagen Formation than to those of the Globigerina-Globorotalia assemblage (Paleocene) from the Qimugen Formation sensu stricto. Neither foraminifera nor dinoflagellates have yet been found in the Gaijietage Formation in any of the three sections.

\section{Kalatar Formation ( $\left.\mathbf{E}_{2} \mathbf{k}\right)$}

In the piedmont of the Tianshan Mountains, the lower part of the Kalatar Formation comprises interbeds of grey thick-bedded to massive limestones, marls, and greyish green mudstones, intercalated with shelly limestones, oolitic limestones, and thin-bedded gypsum. The upper part of the formation consists of grey limestones, shelly limestones, and shelly beds. The thickness of this formation varies greatly from $36 \mathrm{~m}$ in some areas west of Shachen (Text-Fig. 1), to $176 \mathrm{~m}$ in the Wuluokeqiate section.
The Kalatar Formation in the Wuluokeqiate area is lithologically almost the same as in the piedmont of the Tianshan Mountains; however, the upper shelly limestone contains sand and fine pebbles, and its top has yellowish grey massive calcareous coarse pebbly sandstones. The rocks of this formation here are very hard and contain only a few foraminifera (mainly Nonion, Cibicides) and poorly preserved dinoflagellates.

The lithology of the Kalatar Formation in the Qimugen area is similar to that in the Wuluokeqiate area, but the thickness of the formation decreases to $80 \mathrm{~m}$. Quinqueloqulina is the only genus of foraminifera found in this area.

Nine samples macerated from the Kalatar Formation either are barren or contain a few poorly preserved dinoflagellates (Table 1).

\section{Wulagen Formation $\left(\mathbf{E}_{2} \mathbf{w}\right)$}

The Wulagen Formation conformably overlies the Kalatar Formation and is composed of green mudstone, usually intercalated with grey thin-bedded shelly beds, shelly limestones, and shelly marls. There are interbeds of red mudstone and gypsum beds in its upper part. The formation varies in thickness from a few to some tens of metres but is occasionally up to $128 \mathrm{~m}$ thick. It contains abundant and diverse fossil assemblages, including bivalves, gastropods, echinoderms, ostracods, foraminifera, and dinoflagellates.

The Wulagen Formation in the Wuluokeqiate area comprises greyish green, greyish brown, and grey mudstones intercalated with greyish white thin-bedded mudstones, calcareous mudstones, and coarse pebbly sandstones, but shelly, pebbly limestones occur at the bottom. The Wulagen Formation is more clastic in this area than elsewhere in the basin and is only $20 \mathrm{~m}$ thick.

In the Qimugen area, the formation consists mainly of dark grey mudstones, intercalated with dark grey and yellowish green muddy siltstone and shelly limestones; it reaches a thickness of $119 \mathrm{~m}$.

Of seven samples processed from the Wulagen Formation, four contain abundant dinoflagellate assemblages (Table 1).

\section{Zhuoyouleigansu Formation $\left(\mathbf{E}_{2} \mathbf{z}\right)$}

The Zhuoyouleigansu Formation conformably overlies subjacent strata. It comprises massive white gypsum beds at its base with brownish red mudstone intercalated with siltstones, fine-grained sandstones, and thin- to mediumbedded gypsum in the lower part. Its upper part consists of brownish red massive fine-grained sandstone and dark brownish red mudstone. It ranges in thickness from 0 to $125 \mathrm{~m}$. 
The formation is that part previously referred to as the lower member of the original Bashibulake Formation prior to Hao, Zeng, and Li's (1982) separating it from the overlying Bashibulake Formation - which is that part previously referred to as the upper member of the original Bashibulake Formation - on the basis of its foraminiferal content, although the formation is lithologically distinctive. The diagnostic elements of the foraminifera assemblages (Nonion laevis, N. rolshanseni, and Cibicides artemi) are shared by the Zhuoyouleigansu Formation and the underlying Kalatar and Wulagen formations. In contrast, the diverse foraminiferal assemblages of the overlying Bashibulake Formation (sense herein) are dominated by foraminifera of Oligocene age. No dinoflagellates have been found in the Zhouyouleigansu Formation.

\section{Bashibulake Formation $\left(\mathrm{E}_{3} \mathbf{b}\right)$}

The Bashibulake Formation conformably overlies subjacent strata but has been eroded to varying degrees in different places, being absent in some areas but fully exposed in the Wuluokeqiate area, where it ranges in thickness from 210 to $280 \mathrm{~m}$.

Brown mudstone intercalated with greyish green mudstone, muddy siltstone, and sandy shell beds constitutes the lower part of this formation. Interbeds of brown mudstone, sandy mudstone, fine-grained sandstone, and pebbly sandstone form its upper part.

Many sedimentary structures such as undulose-bedding, ripple marks, and cross-bedding have been found in the upper part of Bashibulake Formation. Fossils are concentrated mostly in the lower mudstones; they comprise oysters and other bivalves, gastropods, echinoderms, ostracods, and foraminifera. From the present investigation, moderately diverse dinoflagellate floras have been found in the lower mudstones in both the Wuluokeqiate and Qimugen sections but are absent in the upper part of the formation, where only poorly preserved pollen grains dominated by Ephedripites and Chenopodipollis have been recorded.

Of 24 samples processed from the Bashibulake Formation, 6 yielded abundant dinoflagellates (Table 1).

\section{WUGIA GROUP (MIOCENE)}

The Wugia Group lies disconformably on different parts of the lower Tertiary Kashi Group. It is composed mainly of continental clastic sediments.

Eleven samples were macerated from the Wuluokeqiate section of the Keziloyi Formation, Wugia Group; nine of them are barren, but two contain pollen assemblages dominated by Chenopodiaceae.

\section{Dinoflagellate and Acritarch Zonation and Age Determination of the Yingjiesha and Kashi Groups}

PREVIOUS DINOFLAGELLATE STUDIES

Late Cretaceous dinoflagellates and acritarchs of the Yingjiesha Group from the Kashi area (Text-Fig. 1) were first studied by Yu and Zhang (1980), who divided them in ascending order into three assemblage zones: (1) Cyclonephelium vannophorum-Canningia asper Assemblage Zone, encompassing the lower part of the Wuyitake-Kukebai Formation (see next paragraph for explanation of this "joint" formation) - Cenomanian to early Turonian in age; (2) Palaeohystrichophora infusorioidesSpiniferites ramosus var. ramosus Assemblage Zone, from the upper part of the Wuyitake-Kukebai Formation - late Turonian to Santonian in age; (3) Deflandrea microgranulata-Operculodinium baculatum Assemblage Zone, from the Yigeziya Formation - Campanian or Campanian to early Maastrichtian in age. No dinoflagellates and acritarchs were recorded from the Tuyiluoke Formation by Yu and Zhang (1980).

The stratigraphic division in Yu and Zhang (1980), based on the data offered by Li yu-wen of the Institute of Geology, Chinese Academy of Geological Science (pers. comm., 1982), is different from that of Hao, Zeng, and $\mathrm{Li}$ (1982), the latter being adopted in this paper. The late Cretaceous Yingjiesha Group in the Wuluokeqiate area was divided into three formations by $\mathrm{Yu}$ and Zhang (1980), in ascending order: the Wuyitake-Kukebai Formation, the Yigeziya Formation, and the Tuyiluoke Formation. The Kukebai Formation and the Wuyitake Formation were not distinguished as two distinct units, and the Yigeziya Formation was supposed to exist in the Wuluokeqiate area.

Paleogene dinoflagellates of the Kashi area have not been studied to date.

\section{DEFINITION OF ZONES}

The six Oppel zones defined herein for Upper Cretaceous to Lower Tertiary strata in the Kashi area are discussed here in ascending order; the first three (Zones A-C) are late Cretaceous, and the remainder (Zones D-F) are early Tertiary (Tables 2, 3). Full citation and authorship of taxa mentioned below may be found in the systematic section. 


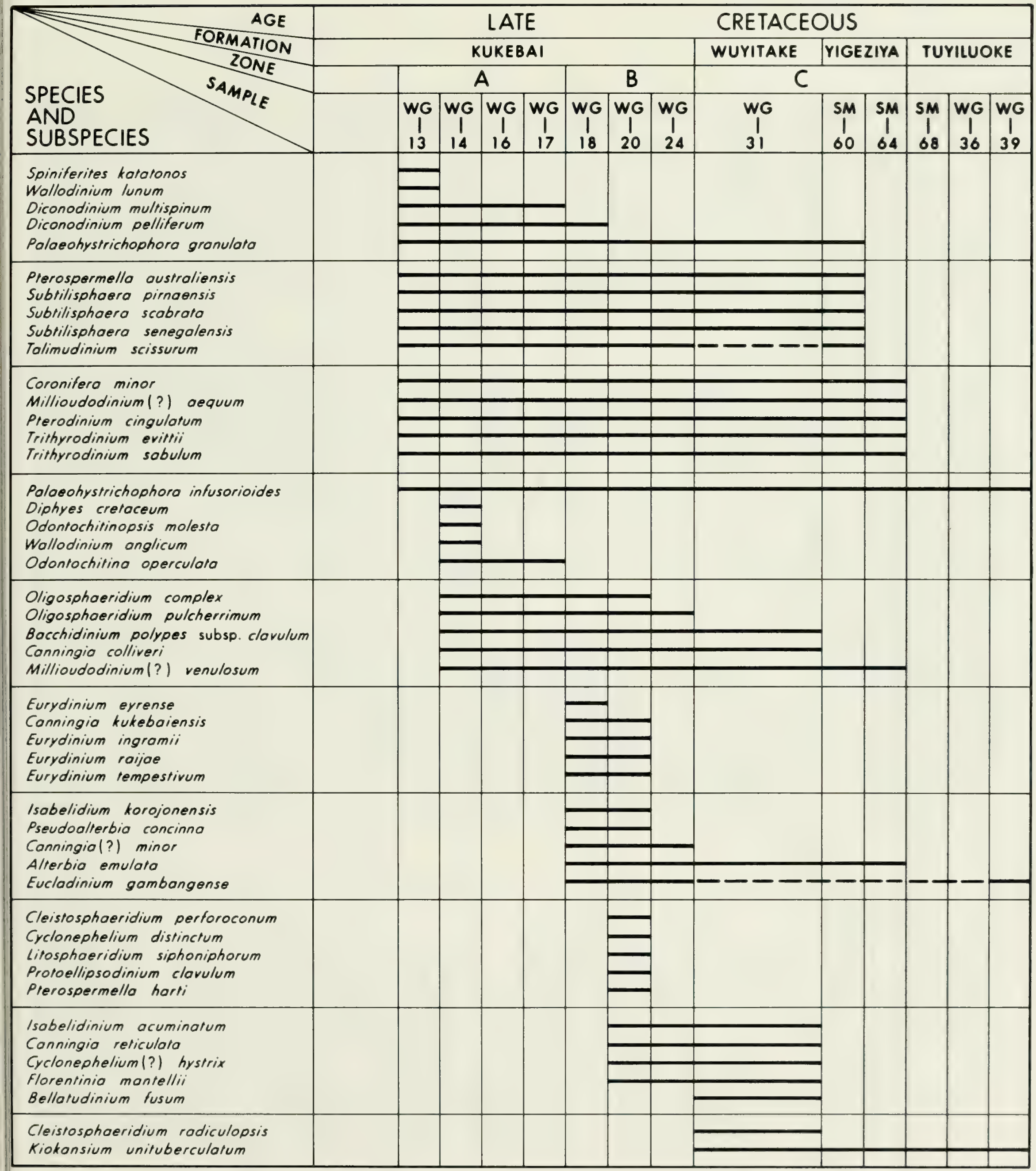

TABLE 2. Range chart of dinoflagellate cysts from the upper Cretaceous of the Tarim Basin. The three zones are defined in the present paper. Ranges indicated are composites from the three sections studied. 


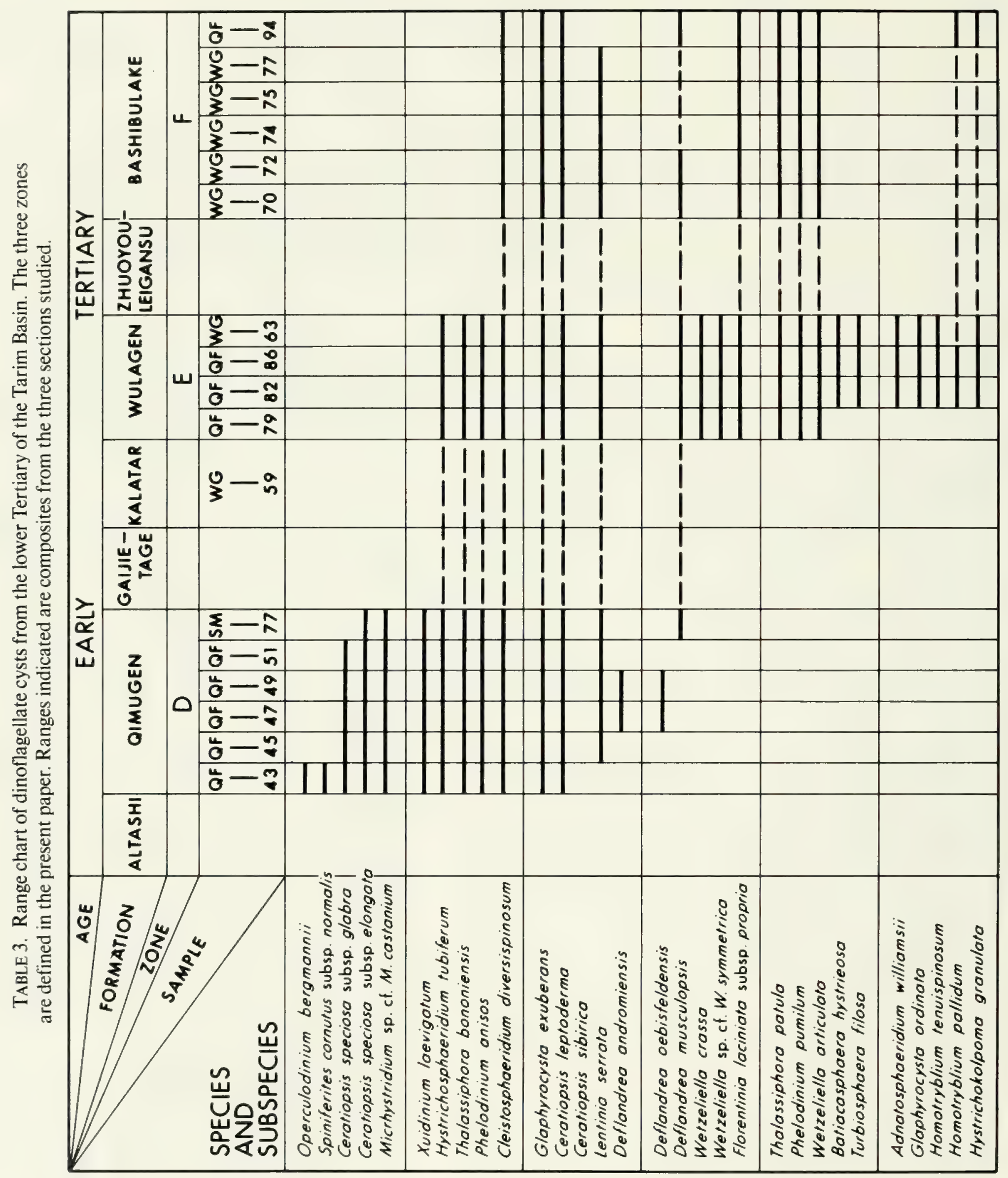




\begin{tabular}{|c|c|c|c|c|c|c|c|c|}
\hline 11 & & & & $\prod$ & & & & \\
\hline 11111 & 1 & & & 11 & & & & \\
\hline 111 & 11 & & & 111 & & & & \\
\hline 11 & 11 & & & $\begin{array}{l}111 \\
11 \\
+1\end{array}$ & & & & \\
\hline $\begin{array}{r}111 \\
111\end{array}$ & $i$ & & & $\begin{array}{l}11 \\
111\end{array}$ & & & 1 & \\
\hline 11111 & 工 & & & 111 & & & & \\
\hline $\begin{array}{lllll}1 & 1 & 1 & 1 \\
1 & 1 & 1 & 1 & 1 \\
1 & 1 & 1 & 1 & 1 \\
\end{array}$ & $\begin{array}{ll}1 & 1 \\
1 & 1 \\
1 & 1\end{array}$ & & & $\begin{array}{llll} & 1 & 1 \\
1 & 1 & 1 \\
1 & 1 & 1 \\
\end{array}$ & & & & \\
\hline & 1 & & & & 1 & 11 & & \\
\hline & & & & & & & & \\
\hline & & & & & & & & \\
\hline & & & & & & & & \\
\hline & & & & & & & & \\
\hline & & & & & & & & \\
\hline & & & & & & & & \\
\hline & & & & & & & & \\
\hline & & 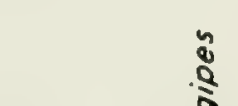 & & & & & & \\
\hline 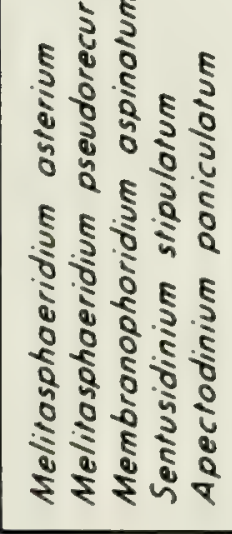 & 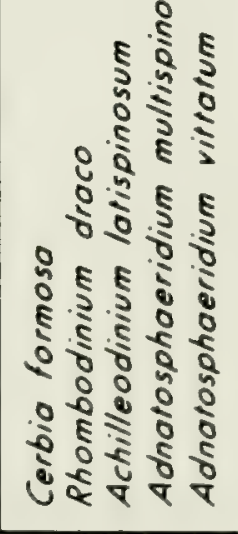 & 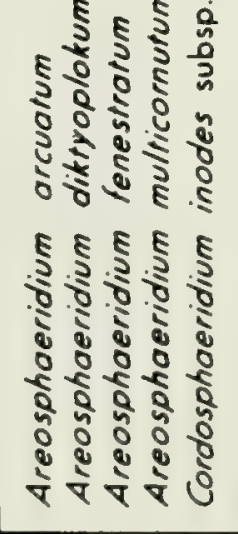 & 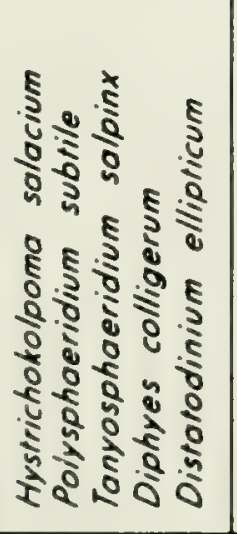 & 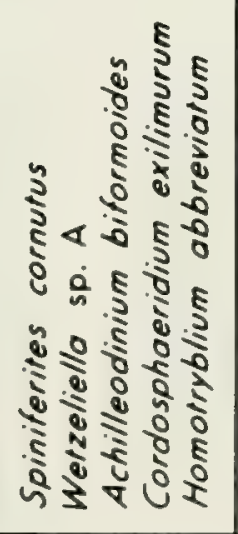 & 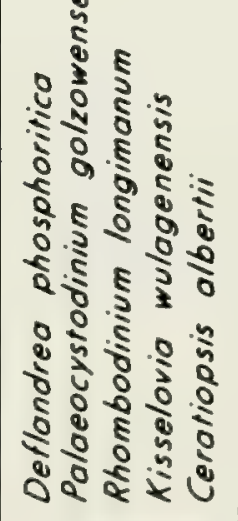 & 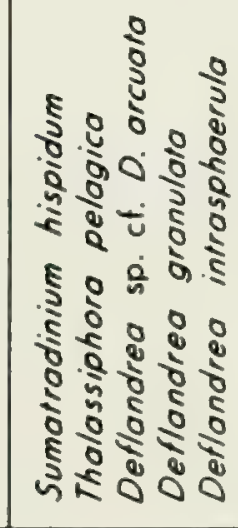 & 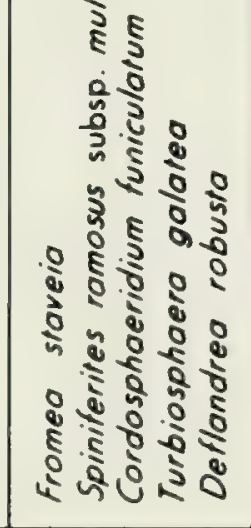 & 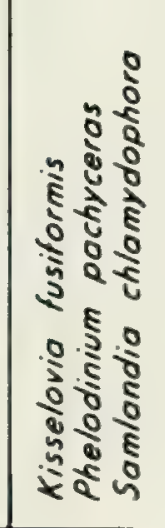 \\
\hline
\end{tabular}




\section{Cyclonephelium brevispinatum Oppel Zone (Zone A)} TYPE SECTION

The middle part of the Kukebai Formation in the Wuluokeqiate section (Text-Fig. 2) from sample WG-13 to WG-17.

\section{DEFINITION}

Cyclonephelium brevispinatum and Palaeohystrichophora infusorioides dominate this zone. Coronifera minor, Millioudodinium (?) aequum, M. (?) venulosum, Oligosphaeridium pulcherrimum, Palaeohystrichophora granulata, Subtilisphaera pirnaensis, S. scabrata, S. senegalensis, Trithyrodinium evittii, T. sabulum, and the acritarchs Leiosphaeridia hyalina and Granodiscus granulatus are common. In addition, Bacchidinium polypes subsp. clavulum, Canningia colliveri, Cyclonephelium vannophorum, Diconodinium multispinum, Diphyes cretaceum, Odontochitina operculata, Odontochitinopsis molesta, Oligosphaeridium complex, Pterodinium cingulatum, Spiniferites katatonos, Wallodinium anglicum, $W$. lunum, and the acritarch Pterospermella australiensis also occur; among these, Diconodinium multispinum, Diphyes cretaceum, Odontochitina operculata, Odontochitinopsis molesta, Spiniferites katatonos, Wallodinium anglicum, and $W$. lunum do not extend above the top of Zone A.

\section{DISCUSSION}

Cyclonephelium brevispinatum has its first record in the upper Hauterivian to the lower Aptian in France (Millioud, 1969) and ranges from the Aptian to the Cenomanian in Australia (Cookson and Eisenack, 1974; Wiseman and Williams, 1974), from the Hauterivian to the Cenomanian in Morocco (Below, 1981), from the Aptian to the Albian in Canada (Singh, 1971; Williams, 1975), and from the Aptian in South West Africa (Davey, 1978). In the present work, this species was found in each zone of the upper Cretaceous; it is most abundant, however, in Zone A. Palaeohystrichophora infusorioides has its reliable records ranging from the Cenomanian to the Maastrichtian in Europe, Australia, North America, and the USSR (Table 4), concurrent in the Cenomanian. Subtilisphaera pirnaensis ranges from the Hauterivian to the Aptian and the lower Turonian to the Coniacian in Europe, and from the upper Albian to the Cenomanian and the Campanian to the Maastrichtian in North America (Harker and Sarjeant, 1975; Harland, 1977). Bacchidinium polypes subsp. clavulum has been recorded from the upper Albian to the Cenomanian of England (Cookson and Hughes, 1964; Davey, 1969). Odontochitina operculata has a total range of Hauterivian to Maastrichtian but has not been found yet in the sediments earlier than the Cenomanian in Denmark (Wilson, 1971), Italy (Corradini, 1973), the offshore North Atlantic (Habib, 1972), Poland (Alberti, 1961; Gorka, 1963), and parts of England, France, Germany, Australia, and North America (Wetzel, 1933a, 1933b; Singh, 1964; Clarke and Verdier, 1967; Davey, 1970; Davey and Verdier, 1973; Norvick and Burger, 1976; Ioannides and Colin, 1977; Harland, 1977). Spiniferites katatonos is found in the upper Cretaceous in Italy (Corradini, 1973). Wallodinium anglicum has been reported from the Barremian to the Cenomanian in Europe (Cookson and Hughes, 1964; Davey, 1970, 1974; Davey and Verdier, 1974) and from the Cenomanian and Campanian in Canada (McIntyre, 1974). W. lunum has been widely reported from the Hauterivian to the upper Cretaceous elsewhere (Cookson and Eisenack, 1960a, 1962; Manum and Cookson, 1964; Davey and Verdier, 1974; Davey, 1974; Norvick and Burger, 1976; Duxbury,

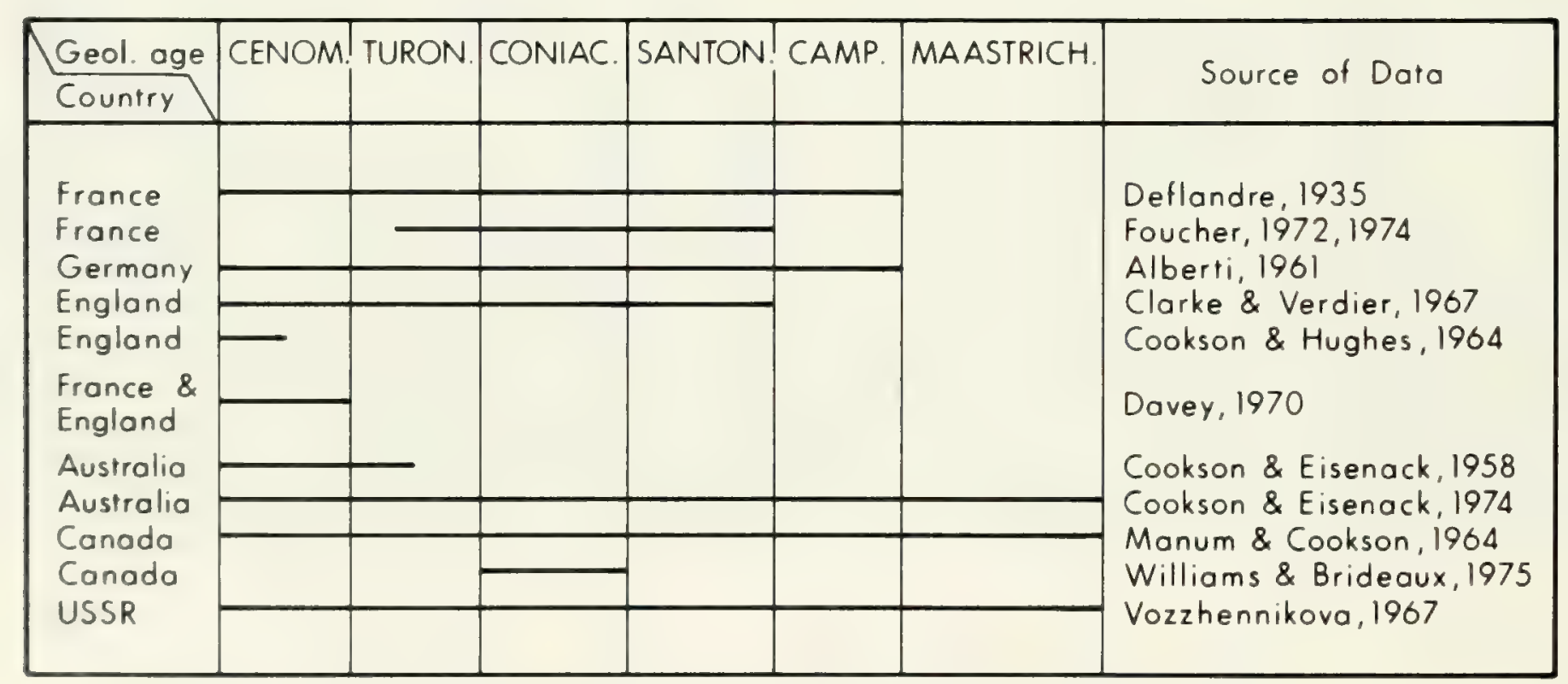

TABLE 4. Reported geological range of Palaeohystrichophora infusorioides. 
1977; Morgan, 1980). It can be seen from the above data that most species in Zone A are very common in the late Early Cretaceous to the early Late Cretaceous except Palaeohystrichophora infusorioides, which has its earliest occurrence in the Cenomanian.

Zone A is similar to the Cyclonephelium vannophorum-Canningia asper Assemblage Zone of $\mathrm{Yu}$ and Zhang (1980), which they thought to be Cenomanian to early Turonian in age. That assemblage and Zone $\mathrm{A}$ are not diverse assemblages; they share five species in common: Canningia colliveri, Coronifera minor, Cyclonephelium vannophorum, Diphyes cretaceum, and $\mathrm{Pa}$ laeohystrichophora infusorioides.

Zone A is also closely comparable to the Hystrichosphaeridium (now Litosphaeridium) siphoniphorum Concurrent Range Zone in southern England of Clarke and Verdier (1967), which is dated as Cenomanian to (?)Turonian in age. Seven species, Canningia colliveri, Odontochitina costata, $O$. operculata, Oligosphaeridium complex, $O$. pulcherrimum, Palaeohystrichophora infusorioides, and Pterodinium cingulatum, occur in both zones. The Cleistosphaeridium (now Bacchidinium) polypes Zone of Williams (1975), later refined by Bujak and Williams (1978), in offshore eastern Canada, which was postulated as Cenomanian, is possibly coeval with Zone A. Thus, it is most likely that Zone A is Cenomanian to Turonian in age.

\section{Alterbidinium emulatum Oppel Zone (Zone B) TYPE SECTION}

The portion of the Wuluokeqiate section from sample WG-18 to WG-24, spanning the upper part of the Kukebai Formation (Text-Fig. 2).

\section{DEFINITION}

Zone B is characterized by a highly diverse assemblage dominated by both deflandreacean forms, such as Alterbidinium and Eurydinium, and skolochorate and spiniferate cysts. The quantitatively dominant species in the assemblage are as follows: Alterbidinium emulatum, Coronifera minor, Cyclonephelium distinctum, Eucladinium gambangense, Eurydinium eyrense, E. ingramii, E. raijae, E. tempestivum, Oligosphaeridium complex, O. pulcherrimum, Palaeohystrichophora infusorioides, Pseudoalterbia concinna, Pterodinium cingulatum, Spiniferites ramosus subsp. multibrevis, Trithyrodinium evittii, T. sabulum, and the acritarchs Leiosphaeridia hyalina and Granodiscus granulatus. Thirty genera and 43 species occur in Zone B, of which the following are restricted to it: Canningia kukebaiensis, C. (?) minor, Cleistosphaeridium perforoconum, Cyclonephelium distinctum, Eurydinium eyrense, E. raijae, E. tempestivum, Isabelidinium acuminatum, Litosphaeridium siphoni- phorum, Protoellipsodinium clavulum, and the acritarch Pterospermella harti.

\section{DISCUSSION}

Isabelidinium acuminatum ranges from the Cenomanian to the lower Turonian in Australia (Cookson and Eisenack, 1958) and from the Cenomanian to the Maastrichtian in North America (McIntyre, 1975) but is restricted to the late Santonian in Europe (Harker and Sarjeant, 1975). The eponymous new species of Zone B, Alterbidinium emulatum, bears a resemblance to $I$. acuminatum. Of the three species of Eurydinium, E. eyrense is Albian to Cenomanian in western Australia (Cookson and Eisenack, 1971), E. ingramii occurs from the Albian to the Senonian in western Australia (Cook son and Eisenack, 1970), and E. raijae is recorded only in the middle Maastrichtian in Sweden (Kjellström, 1973). Oligosphaeridium complex and $O$. pulcherrimum have a cosmopolitan occurrence of Valanginian to Maastrichtian and Kimmeridgian to Maastrichtian respectively (Yun, 1981; Below, 1981). Eucladinium gambangense occurs in the Senonian in western Australia (Cookson and Eisenack, 1970), whereas Litosphaeridium siphoniphorum has previously been recorded from the Albian to the Cenomanian elsewhere.

Zone B is closely comparable to the Palaeohystrichophora infusorioides-Spiniferites ramosus var. ramosus Assemblage Zone of Yu and Zhang (1980), which they thought to be of late Turonian to Santonian age, partly on the basis of Turonian pelecypods and ammonites (e.g. Rhynohotreon suborbieulatum, Ostrea, Thomasites, Placenticeras placenta). Both Zone B and Yu and Zhang's (1980) second assemblage zone represent that part of the Wuluokeqiate section with the most diverse Cretaceous dinoflagellate assemblages. They share eleven taxa in common: Canningia colliveri, C. reticulata, Coronifera minor, Cyclonephelium distinctum, C. vannophorum, Florentinia mantellii, Oligosphaeridium complex, O. pulcherrimum, Palaeohystrichophora infusorioides, Pterodinium cingulatum, and Spiniferites ramosus subsp. multibrevis. The eponymous species of the Oligosphaeridium pulcherrimum Assemblage Zone of offshore southeastern Canada (Williams, 1975; Bujak and Williams, 1978) is abundant in Zone B; the $O$. pulcherrimum zone was considered by Bujak and Williams (1978) to be of Coniacian age; therefore, the probable age determination for Zone B is Turonian to Coniacian or Turonian to Santonian.

\section{Canningia reticulata Oppel Zone (Zone C) TYPE SECTION}

The middle part of the Wuyitake Formation in the Wuluokeqiate section from WG-31 (Text-Fig. 2). 
OTHER LOCALITY

The Wuyitake to Yigeziya formations in the Simuhana section from sample SM-51 to SM-64.

\section{DEFINITION}

Canningia reticulata sp. nov. predominates in quantity in Zone C. Apart from Cleistosphaeridium radiculopsis $\mathrm{sp}$. nov., Kiokansium unituberculatum, and Bellatudinium fusum, no taxa that are absent from the underlying Zones $\mathrm{B}$ and $\mathrm{A}$ enter the record in Zone $\mathrm{C}$. In addition to the abundant species Canningia reticulata, the following species are common in Zone C: Cleistosphaeridium radiculopsis, Coronifera minor, Florentinia cooksoniae, Kiokansium unituberculatum, Millioudodinium (?) aequum, M. (?) venulosum, Palaeohystrichophora infusorioides, Subtilisphaera pirnaensis, S. senegalinium, and Talimudinium scissurum. Most of these species that are common in Zone A and/or Zone B have their youngest occurrence in Zone $\mathrm{C}$.

\section{DISCUSSION}

Canningia reticulata, first recorded from the Tithonian in Australia (Cookson and Eisenack, 1960b), ranges from the Tithonian to the Santonian in Australia, Europe, North America, and Africa (Davey and Verdier, 1974; Williams and Brideaux, 1975; Below, 1981). Bellatudinium fusum was reported from the latest Cretaceous Dalanshan Formation of Guangdong Province, China (Yu et al., 1981), whereas Florentinia cooksoniae has a previous record of Barremian to late Albian date. There are no index fossils in Zone $\mathrm{C}$ to indicate the detailed age for Zone $\mathrm{C}$; however, none of the species in this zone range into the Tertiary. Zone $\mathrm{C}$ is, therefore, believed to be late Cretaceous, that is, Coniacian or post-Coniacian in age.

\section{Phelodinium anisos Oppel Zone (Zone D) TYPE SECTION}

The portion of the Qimugen section from samples QF-43 to QF-51, spanning more than the lower half of the Qimugen Formation (Text-Fig. 2).

\section{OTHER LOCALITY}

The Simuhana section of samples SM-77 to SM-78, from the Qimugen Formation.

\section{DEFINITION}

A dramatic change occurs between Zone $\mathrm{C}$ and Zone D, which are separated, however, by a barren interval. Most of the species occurring in Zones $\mathrm{A}$ to $\mathrm{C}$ do not range into Zone D, but many new elements appear in Zone D. The most abundant taxa in this zone are Achomosphaera crassipellis, A. ramulifera, Ceratiopsis speciosa, C. speciosa subsp. elongata, C. speciosa subsp. glabra,
Cleistosphaeridium diversispinosum, Glaphyrocysta exuberans, Lejeunecysta hyalina, Phelodinium anisos, Spiniferites ramosus subsp. granomembranaceus, $S$. ramosus subsp. granosus, Xuidinium laevigatum, and a small acritarch here identified as Micrhystridium sp. cf. $M$. castanium. In addition, the following species also occur in Zone D: Araneosphaera araneosa, Ceratiopsis leptoderma, Deflandrea andromiensis, D. oebisfeldensis, Exochosphaeridium muelleri, E. phragmites, Hystrichosphaeridium tubiferum, $H$. tubiferum subsp. brevispinum, Lentinia serrata, Spiniferites cornutus subsp. normalis, and Thalassiphora bononiensis.

\section{DISCUSSION}

Many species or subspecies in Zone D have been reported from the Paleocene to the Oligocene in different areas. For example, Ceratiopsis speciosa ranges from the Campanian to the lower Eocene in North America (Stanley, 1965; Drugg, 1967; May, 1980) and the USSR (Vozzehnnikova, 1967) and from the upper Paleocene to the lower Eocene of Germany (Alberti, 1959; Gocht, 1969). Ceratiopsis speciosa subsp. glabra is recorded from the upper Paleocene of Germany (Gocht, 1969), and Ceratiopsis leptoderma occurs in the Paleocene of West Siberia (Vozzehnnikova, 1965, 1967). Cleistosphaeridium diversispinosum occurs in the Eocene of England (Davey et al., 1966). Glaphyrocysta exuberans ranges from the lower Eocene to the upper Oligocene of Australia (Deflandre and Cookson, 1955), Germany (Brosius, 1963), England, and Belgium (Davey et al., 1966). Lejeunecysta hyalina has its lower Eocene to lower Oligocene record from Germany (Gerlach, 1961; Gocht, 1969). Deflandrea andromiensis is found from the Eocene to the Oligocene in West Siberia (Vozzehnnikova, 1967), D. oebisfeldensis ranges from the Paleocene to the Late Oligocene in Germany and the USSR (Alberti, 1959; Vozzehnnikova, 1967; Benedek, 1972), and Achomosphaera crassipellis is found from the lower Eocene of Australia, Germany, and Belgium (Deflandre and Cookson, 1955; Morgenroth, 1966). Spiniferites cornutus subsp. normalis occurs in the Paleocene of Australia (Cookson and Eisenack, 1974). S. ramosus subsp. granosus has a long range of Hauterivian to Oligocene in Europe (Yun, 1981) and a short range of Campanian to Maastrichtian in the United States (May, 1980). The specimens of small size $(20-25 \mu \mathrm{m})$ of the acritarch Micrhystridium sp. cf. M. castanium found in Zone D are similar to those found in the Lower Paleocene of Argentina (Heisecke, 1970). In addition, few taxa such as Exochosphaeridium muelleri and E. phragmites have only been found previously from the Albian to the Senonian in Europe.

Summarizing the above, it can be postulated that the most acceptable date for Zone D is late Paleocene to early 
Eocene in age. That Late Paleocene dinoflagellate assemblage from West Germany described by Gocht (1969) dominated by Areoligera senonensis is closely comparable to Zone D. This $A$. senonensis assemblage contains eight taxa, two of which, Ceratiopsis speciosa subsp. glabra and Spiniferites ramosus, are shared with Zone D. Thus Zone D is probably late Paleocene, which partly coincides with the conclusion that Zone D is middle to late Paleocene, based on foraminifera. The absence of Wetzeliellaceae also favours a late Paleocene age.

\section{Turbiosphaera filosa Oppel Zone (Zone E) TYPE SECTION}

The Wulagen Formation in Qimugen section from samples QF-79 to QF-86 (Text-Fig. 2).

\section{OTHER LOCALITY}

The Wulagen Formation in the Wuluokeqiate section from samples WG-63 to WG-65.

\section{DEFINITION}

More than 50 taxa that are absent in the underlying Zones A to D have their earliest occurence in Zone E, such as Achilleodinium biformoides, A. latispinosum, Adnatosphaeridium multispinosum, A. williamsii, Areosphaeridium diktyoplokum, $A$. fenestratum, $A$. multicornutum, Cordosphaeridium exilimurum, Deflandrea phosphoritica, Diphyes colligerum, Distatodinium ellipticum, Glaphyrocysta intricata, G. laciniiformis, Homotryblium abbreviatum, $H$. pallidum, $H$. tenuispinosum, Hystrichokolpoma rigaudiae, $H$. salacium, Kisselovia coleothrypta, Melitasphaeridium asterium, M. pseudorecurvatum, Palaeocystodinium golzowense, Rhombodinium draco, $R$. longimanum, Thalassiphora pelagica, Turbiosphaera filosa, and Wetzeliella articulata. The taxa most frequently found in Zone E are Achomosphaera ramulifera, Cerbia formosa, Cleistosphaeridium diversispinosum, Cordosphaeridium exilimurum, Deflandrea musculopsis, Homotryblium pallidum, $H$. tenuispinosum, Melitasphaeridium asterium, $M$. pseudorecurvatum, Membranophoridium aspinatum, Rhombodinium draco, and Spiniferites ramosus subsp. multibrevis.

The following taxa are restricted to Zone E: Achilleodinium latispinosum, Adnatosphaeridium multispinosum, $A$. vittatum, Areosphaeridium arcuatum, $A$. diktyoplokum, A. fenestratum, A. multicornutum, Batiacasphaera hystrieosa, Ceratiopsis albertii, Cordosphaeridium inodes subsp. longipes, Diphyes colligerum, Distatodinium ellipticum, Glaphyrocysta intricata, Polysphaeridium subtile, Spiniferites cornutus, Sumatradinium hispidum, Tanyosphaeridium salpinx, Thalassiphora flammea, T. pelagica, Turbiosphaera filosa, Wetzeliella wulagenensis, and $W$. sp. cf. W. symmetrica.

\section{DISCUSSION}

This zone, with 85 taxa of 40 genera, is the most diverse and abundant amongst the 6 zones recognized. As can be seen from Table 5, it is most likely that Zone $\mathrm{E}$ is Eocene in age. Eocene dinoflagellate biostratigraphy of southern England has been studied intensively by Davey et al. (1966), Costa and Downie (1976), Eaton (1976), Harland (1979), and Bujak et al. (1980a). Bujak et al. (1980a) defined 13 assemblage zones in the lower Eocene to upper Eocene strata (London Clay to Barton Beds) of southern England. It is impossible to compare in detail their zonation with Zone E, because the latter comprises a mere 5 samples. However, 53 of the 85 taxa from Zone $\mathrm{E}$ can be found in various Eocene assemblage zones of Bujak et al. (1980a) from southern England. Among these species, Membranophoridium aspinatum, Areosphaeridium fenestratum, Rhombodinium draco, and $R$. longimanum have their earliest occurrences in the upper Eocene elsewhere in the world from the previous records. Therefore, Zone E is probably late Eocene. However, since the late Eocene age assigned to the Barton Beds in southern England is still controversial (Bujak, 1979) and they may include some middle Eocene, Zone E may contain part of the middle Eocene too. Recently, Berggren et al. (1985) have placed the Bartonian in the upper part of the middle Eocene. If that placement is followed, it will affect these age assignments. The Diphyes colligerum Assemblage Zone of Williams in Canada (1975), which was provisionally assigned a late Eocene age, contains Areosphaeridium diktyoplokum, Glaphyrocysta intricata, Diphyes colligerum, and Rhombodinium draco, which are common to Zone $\mathrm{E}$.

\section{Deflandrea intrasphaerula Oppel Zone (Zone F) TYPE SECTION}

The portion of the Wuluokeqiate section from samples WG-70 to WG-77, spanning more than the lower part of the Bashibulake Formation (see Text-Fig. 2).

\section{OTHER LOCALITY}

The Qimugen section, sample QF-94, lower part of the Bashibulake Formation.

\section{DEFINITION}

The following have their last occurrence in Zone F: Apectodinium paniculatum, Ceratiopsis leptoderma, Cordosphaeridium exilimurum, Deflandrea phosphoritica, Glaphyrocysta exuberans, G. laciniiformis, Homotryblium abbreviatum, Kisselovia coleothrypta, Lejeunecysta hyalina, Lentinia serrata, Melitasphaeridium asterium, M. pseudorecurvatum, Palaeocystodinium golzowense. Phelodinium pumilum, Rhombodinium draco, $R$. longimanum, and Wetzeliella articulata. The follow 


\begin{tabular}{|c|c|c|c|c|c|c|c|}
\hline Taxa Range & $\begin{array}{l}\text { Early } \\
\text { Paleocene }\end{array}$ & $\begin{array}{l}\text { Middle } \\
\text { Paleocene }\end{array}$ & $\begin{array}{l}\text { Late } \\
\text { Paleocene }\end{array}$ & \begin{tabular}{|l|l|} 
Early \\
Eocene
\end{tabular} & $\begin{array}{l}\text { Middle } \\
\text { Eocene }\end{array}$ & $\begin{array}{l}\text { Late } \\
\text { Eocene }\end{array}$ & Oligocene \\
\hline \multicolumn{8}{|l|}{$\begin{array}{l}\text { Achilleodinium latispinosum } \\
\text { Adnatosphaeridium multispinosum }\end{array}$} \\
\hline \multirow{3}{*}{\multicolumn{8}{|c|}{$\begin{array}{l}\text { Areosphaeridium dikiyoplakum } \\
\text { Areosphaeridium fenestralum } \\
\text { Areosphaeridium mulricornutum } \\
\text { Cordosphaeridium exilimurum }\end{array}$}} \\
\hline & & & & & & & \\
\hline & & & & & & & \\
\hline \\
\hline \\
\hline & & & & & & & \\
\hline \\
\hline \\
\hline \\
\hline \multirow{2}{*}{\multicolumn{8}{|c|}{$\begin{array}{l}\text { Hystrichokolpoma salacium } \\
\text { Kisselovia coleothrypta }\end{array}$}} \\
\hline & & & & & & & \\
\hline \\
\hline $\begin{array}{l}\text { Melitasphaeridium pseudorecurvalum } \\
\text { Membranophoridium aspinalum }\end{array}$ & & & & & & & \\
\hline \multicolumn{8}{|l|}{$\begin{array}{l}\text { Palaeocystodinium golzowense } \\
\text { Rhombodinium draco }\end{array}$} \\
\hline \\
\hline Thalassiphora patula & & & & & & & \\
\hline & & & & & & & \\
\hline & & & & & & & \\
\hline
\end{tabular}

TABLE 5. The total range of selected species in Zone E. Sources of data are mainly from the following: Gerlach, 1961; Davey et al., 1966; Eisenack, 1967; Cookson and Eisenack, 1967; Vozzhennikova, 1967; Gocht, 1969; Benedek, 1972; Corradini, 1973; Harker and Sarjeant, 1975; Williams and Brideaux, 1975; Bujak, 1976; Costa and Downie, 1976; Eaton, 1971, 1976; Harland, 1979; Bujak, 1979; Bujak et al., 1980a; Liengjarern, Costa, and Downie, 1980; Islam, 1983.

ing are restricted to Zone F: Cordosphaeridium funicula tum, Deflandrea sp. cf. D. arcuata, D. granulata, $D$. intrasphaerula, D. robusta, Fromea staveia, Kisselovia fusiformis, Phelodinium pachyceras, Samlandia chlamy. dophora, Spiniferites ramosus subsp. multiplicatus, Turbiosphaera galatea, and Wetzeliella gochtii.

\section{DISCUSSION}

The dinoflagellate assemblages of Zone $\mathrm{F}$ are less diverse than those of the underlying Turbiosphaera filosa Zone, although both of them share several species that range from the Eocene to the Oligocene. Those species are Deflandrea phosphoritica, Glaphyrocysta laciniiformis, Homotryblium abbreviatum, Kisselovia coleothrypta, Melitasphaeridium pseudorecurvatum, Palaeocystodinium golzowense, Rhombodinium draco, R. longimanum, and Wetzeliella articulata. Among the species restricted to Zone F, Cordosphaeridium funiculatum was found from lower Eocene strata in northern Germany and Belgium (Morgenroth, 1966) and has its latest occurrence in the lower Oligocene of Canada (Williams, 1975). Deflandrea arcuata was recorded from the upper Eocene to lower Oligocene in the USSR (Vozzhennikova, 1967), and $D$. granulata was reported from the Eocene to lower Oligocene in Argentina (Menendez, 1965). Phelodinium pachyceras has been reported from the upper Eocene to lower Oligocene of southern England (Liengjarern, Costa, and Downie, 1980), and Wetzeliella gochtii was recorded from the middle Oligocene in southern England (Costa and Downie, 1976).

Zone F can be compared with the lower Oligocene dinoflagellate assemblages of southern England (Liengjarern, Costa, and Downie, 1980). Both the southern England assemblages and Zone $\mathrm{F}$ are less diverse and share six species: Deflandrea phosphoritica, Homotryblium abbreviatum, $H$. pallidum, Kisselovia coleothrypta, Phelodinium pachyceras, and Wetzeliella gochtii. Zone F is also comparable to the Deflandrea heterophlycta Assemblage Zone of Williams (1975) in offshore eastern Canada, which was provisionally dated as early Oligocene.

Taking all these facts into account, perhaps the most reasonable date for Zone $\mathrm{F}$ is early Oligocene rather than late Eocene. That conclusion coincides with the age 
determination based on foraminifera by Hao, Zeng, and Li (1982), who concluded that the entire Bashibulake Formation was Oligocene.

\section{AGE DETERMINATION OF THE FORMATIONS (Table 6)}

\section{Kukebai Formation}

No dinoflagellate cysts occur in the lower part of the Kukebai Formation, which is dated as Cenomanian on the basis of its content of foraminifera. Zones A and B occur in the middle and upper parts of the Kukebai Formation respectively. Zone $\mathrm{A}$ is Cenomanian to Turonian in age, and Zone B is Turonian to Coniacian or Santonian in age. Consequently, the whole Kukebai Formation is probably Cenomanian to Coniacian or Santonian in age.

\section{Wuyitake and Yigeziya Formations}

Zone $\mathrm{C}$ is Coniacian to post-Coniacian or post-Coniacian and is confined to these two formations.

\section{Tuyiluoke Formation}

The samples from the Tuyiluoke Formation are mainly brownish red mudstone and gypsiferous mudstone and contain poorly preserved Alterbidinium sp., Kiokansium sp., Eucladinium gambangense, Palaeohystrichophora infusorioides, Trithyrodinium sp., Diconodinium $\mathrm{sp}$., and pollen grains of Classopollis and Chenopodipollis (TextFig. 5.1,2). In addition, an organic form incerta sedis with an elongate outline and a smooth, nonstructured wall occurs in two samples (Text-Fig. 5.3,4). Sample WG-39 contains abundant Pediastrum sp. (Text-Fig. 5.5). The last appearance of Palaeohystrichophora infusorioides in England is thought to be Maastrichtian (Clarke and Verdier, 1967:84), and in North America this species ranges up to the Lower Maastrichtian (Harker and Sarjeant, 1975). In the present area, $P$. infusorioides never appears above the Tuyiluoke Formation. Thus, presumably, the Tuyiluoke Formation may represent any time between the Santonian and the Maastrichtian.

\section{Altashi Formation}

The Altashi Formation outcrops in three sections and is composed chiefly of massive gypsum beds, gypsiferous mudstone, and dolomitic limestone, in which fossils are absent or scarce. Prolonged search, however, has yielded many poorly preserved dinoflagellate cysts and a few pollen grains. Cyclonephelium brevispinatum, Palaeoperidinium sp., Leiosphaeridia hyalina, and pollen grains of Monoporopollenites (Text-Fig. 5.6) occur in samples

\begin{tabular}{|c|c|c|}
\hline $\begin{array}{l}\text { Lithostratigraphic } \\
\qquad \text { Sequence }\end{array}$ & Dinoflagellate Oppel Zone & Age \\
\hline \multirow{2}{*}{ Bashibulake Formation } & & Middle to Late Oligocene \\
\hline & Deflandrea intrasphaerula (F) & Early Oligocene \\
\hline Zhuoyouleigansu Formation & & Late Eocene \\
\hline Wulagen Formation & Turbiosphaera filosa (E) & (Middle-) Late Eocene \\
\hline \multicolumn{2}{|l|}{ Kalatar Formation } & \multirow{2}{*}{ Early-Middle Eocene } \\
\hline Gaijietage Formation & & \\
\hline Qimugen Formation & Phelodinium anisos (D) & (Middle -) Late Paleocene \\
\hline Altashi Formation & & ? Early-Middle Paleocene \\
\hline \multicolumn{2}{|l|}{ Tuyiluoke Formation } & \multirow{3}{*}{ Post-Coniacion - ? Maastrichtian } \\
\hline Yigeziya Formation & \multirow{2}{*}{ Canningia reticulata (C) } & \\
\hline Wuyitake Formation & & \\
\hline \multirow{2}{*}{ Kukebai Formation } & Alterbidinium emulatum (B) & Turonian-Coniacian (or Santonian) \\
\hline & Crclonephelium brevispinatum (A) & Cenomanian - Turonian \\
\hline
\end{tabular}

TABLE 6. Distribution and age of dinoflagellate zones in upper Cretaceous and lower Tertiary formations of the Tarim Basin. 


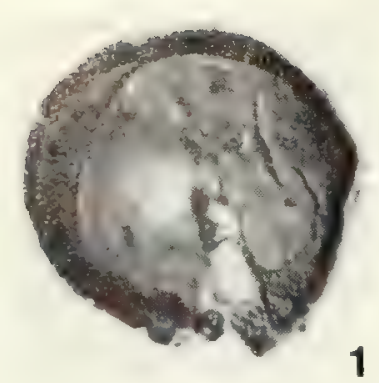

1

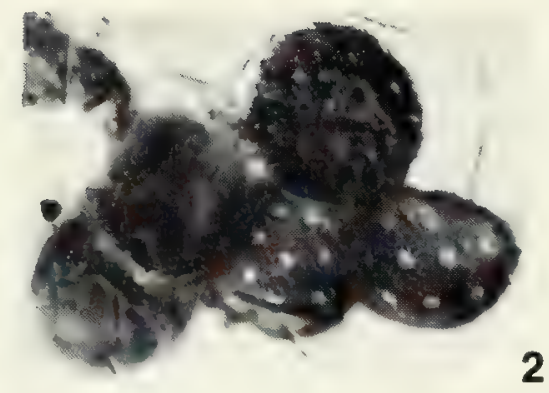

2

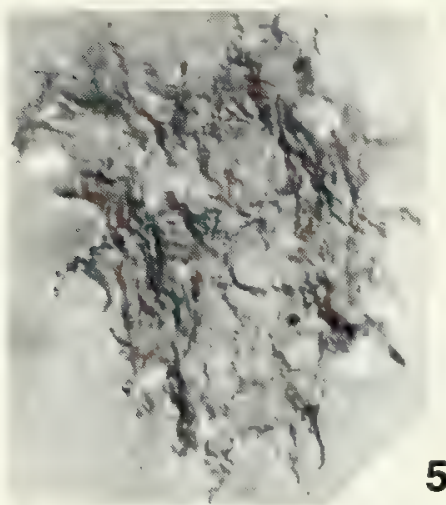

5

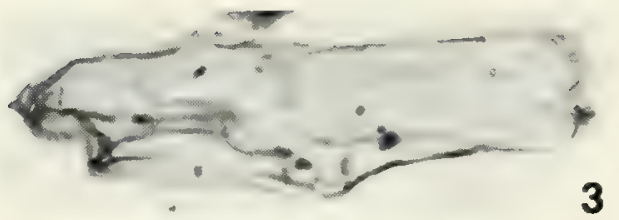

3

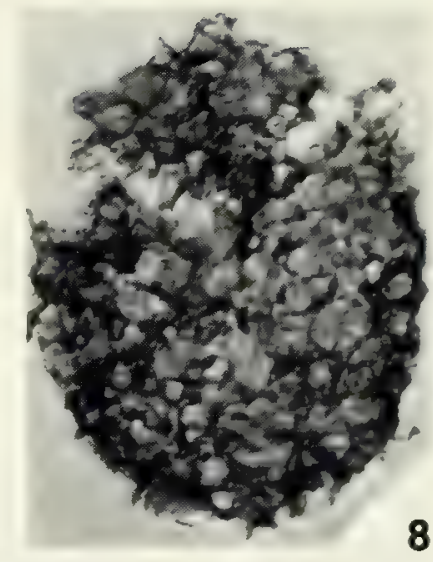

4

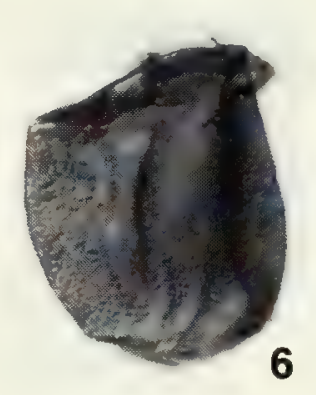

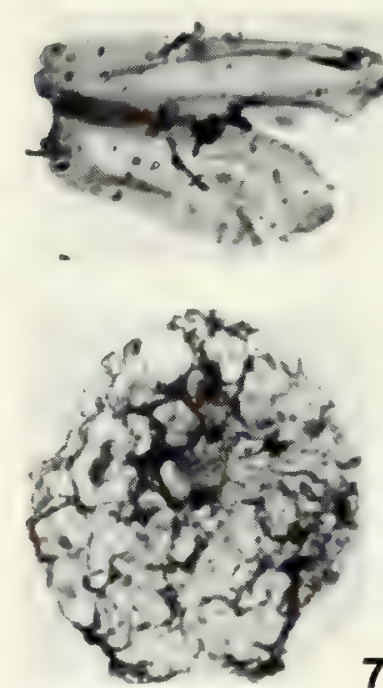

TEXT-FIG. 5. Various terrestrial and marine palynomorphs from Xinjiang Province. See text for explanation. All figures $\times 500$ unless otherwise stated. 1, Classopollis sp., Tuyiluoke Formation $\left(\mathrm{K}_{2} \mathrm{t}\right)$, SM-68; $\mathrm{A}_{2} ; 35.2 / 102.9(\times 1000)$. 2, Chenopodipollis sp., Tuyiluoke Formation $\left(\mathrm{K}_{2} \mathrm{t}\right), \mathrm{SM}-68 ; \mathrm{A}_{4} ; 22.5 / 95.3$ $(\times 1000) .3$, Acritarch incertae sedis Form A, Altashi Formation $\left(E_{1} a\right)$, WG-42; $A_{3} ; 47.3 / 107.6 .4$, Acritarch incertae sedis Form B, Tuyiluoke Formation $\left(\mathrm{K}_{2} \mathrm{t}\right)$, SM-68; $\mathrm{A}_{3} ; 32.2 / 100.8$. 5. Pediastrum sp., Tuyiluoke Formation $\left(\mathrm{K}_{2} \mathrm{t}\right)$, WG-39; 43.8/104.0. 6, Monoporopollenites sp., Altashi Formation $\left(\mathrm{E}_{1} \mathrm{a}\right)$, WG-42; $\mathrm{A}_{3} ; 42.2 / 99.0(\times 1000) .7$, 8, Dinoflagellate incertae sedis Forms A and $\mathrm{B}$, respectively; specimens showing poor preservation; Altashi Formation ( $\left.\mathrm{E}_{1} \mathrm{a}\right)$. 7. QF-41; $\mathrm{A}_{4}$; 55.4/107.5. 8. QF-41; $\mathrm{A}_{2}$; 58.2/104.6. 9, Ephedripites sp., Bashibulake Formation ( $\left.\mathrm{E}_{3} \mathrm{~b}\right)$, WG-87; $\mathrm{A}_{1} ; 40.3 / 104.5$.

WG-42 and SM-75 of the Altashi Formation. An assemblage of very poorly preserved dinoflagellate cysts and Pediastrum sp. was encountered in sample QF-41. These dinoflagellates uniformly have an irregular reticulate wall, which is almost certainly a preservational feature. Many of these are large (Text-Fig. 5.7,8), some with a peridinioid shape and an apical horn and two equal antapical horns and some with a pentagonal to rhombic Wetzeliella-shape and a few remaining processes. The former may be a genus such as Lejeunecysta or Deflandrea, the latter is presumably Apectodinium or Wetzeliella. Thus, the age of the Altashi Formation is more likely Tertiary than late Cretaceous, probably early Paleocene or early to middle Paleocene. However, if the identification of Wetzeliella is confirmed in this formation, an Eocene age would be indicated. Further work is necessary to elucidate geochronological relationships.

\section{Qimugen Formation}

The samples from the upper part of the Qimugen Formation are devoid of dinoflagellate cysts. Zone D, which is late or middle to late Paleocene in age, occurs in the lower part of the Qimugen Formation. Considering that the overlying Gaijietage Formation, which also lacks distinguishable dinoflagellate cysts, is early Eocene in age, based on foraminiferal evidence (Hao, Zeng, and $\mathrm{Li}, 1982$ ), the Qimugen Formation as a whole is most likely late Paleocene or middle to late Paleocene in age.

\section{Gaijietage Formation}

This formation is early Eocene in age based on foraminiferal evidence (Hao, Zeng, and Li, 1982), as mentioned in the section on stratigraphy.

\section{Kalatar Formation}

The Kalatar Formation, immediately above the Gaijietage Formation, contains sparse pollen grains assigned to Chenopodiapollis, Monoporopollenites, Tricolpopollenites, Betulaepollenites, and Quercoidites, and very poorly preserved dinoflagellate cysts - Thalassiphora bononiensis and Thalassiphora petila Corradini. The latter two species indicate that the Kalatar Formation is early to middle Eocene in age, this being in accord with the dating of the underlying and overlying formations.

\section{Wulagen Formation}

Zone $\mathrm{E}$ and hence the Wulagen Formation are probably late Eocene or possibly middle to late Eocene in age. 


\section{Zhuoyouleigansu Formation}

This formation is late Eocene in age, based on foraminiferal evidence (Hao, Zeng, and Li, 1982), as stated in the stratigraphy section.

\section{Bashibulake Formation}

Zone $\mathrm{F}$ and hence the lower part of the Bashibulake Formation are early Oligocene in age. The samples in Zone F (from WG-79 to WG-84) contain only a few angiosperm pollen grains (e.g., Ephedripites sp., Text-Fig. 5.9) and very few broken and poorly preserved dinoflagellate cysts, which provided little evidence on age for the upper part of the Bashibulake Formation. However, the whole Bashibulake Formation contains Cibicidoides fauna represented by Cibicidoides pseudoungerianus (Cushman) Hao and Zeng, C. ovaliformis Hao and Zeng, 1982, Baggina trapezoida Hao and Zeng, Spiroplectammina phoxa Hao and Zeng, and Cibicides borislavensis Aisenstat, which Hao, Zeng, and Li (1982) dated as Oligocene. As a result the upper part of the Bashibulake Formation is likely to be middle to late Oligocene in age.

\section{Wugia Group}

The samples from WG-87 to WG-100 contain only sparse pollen and spores. The Miocene age of the Wugia Group is based on foraminiferal evidence (Hao, Zeng, and $\mathrm{Li}, 1982$ ).

\section{Palaeoecology and Palaeogeography}

Palaeoecologic and palaeogeographic reconstructions depend on data from various disciplines. Several attempts have been made during the past two decades by palynologists to use dinoflagellates and acritrachs as palaeoenvironmental indicators and to relate different kinds of dinoflagellate assemblages to different palaeoenvironments. However, it is our intention in this section to draw upon sedimentological and general palaeontological, as well as palynological, data to interpret late Cretaceous and early Tertiary palaeoenvironments in the Kashi area, western Tarim Basin.

Staplin (1961) recognized three different acritarch distribution patterns with regard to Devonian reefs. Simple spherical forms are widespread, from beds interfingering with reef carbonate into off-reef areas. Thin-spined species are also widespread but are seldom found within $1.6 \mathrm{~km}$ of the reefs. Thick-spined and polyhedral forms occur in off-reef strata but seldom near reefs. Vozzhennikova (1965) suggested that thick twolayered dinoflagellate cysts were associated with unstable conditions, and thick-walled cysts were concentrated in the littoral zone, and thin-walled forms with delicate processes were largely restricted to open-marine environments. In their studies of the Oligocene Vicksburg Formation of the United States, Scull et al. (1966) proposed that thin-spined cysts represented shallowwater conditions, and cysts that bore larger, more complex processes usually represented deeper-water environments. Downie, Hussain, and Williams (1971) described four Eocene associations from southeastern England, which they interpreted as being controlled by changing environmental circumstances. Two of these associations, respectively dominated by the genera Spiniferites and Areoligera, may represent open-marine conditions. Another association, dominated by the acritarch genera Micrhystridium and Comasphaeridium, indicated the initial and closing stages of marine transgressions, and the remaining association, dominated by the cavate cyst Wetzeliella, may have represented estuarine conditions. Harland (1973) defined the gonyaulacacean ratio as the number of gonyaulacacean cyst species divided by the total number of peridiniacean cyst species. He found that the gonyaulacacean ratio was higher in more open-marine late Cretaceous environments and also noted that the gonyaulacacean ratio in deep-sea cores from the Caribbean studied by Wall (1967) was 18.0, whereas for a nearshore population at Woods Hole, Massachusetts (Wall and Dale, 1968), the gonyaulacacean ratio was only 0.44 .

Goodman (1979), in a study of dinoflagellates from the lower Eocene of Maryland, recognized six dinoflagellate cyst communities. From his study, he concluded that environments did control the dinoflagellate assemblages. The shallow-water deposition is indicated by the relatively common occurrence of Lingulodinium machaerophorum, which is usually found in brackish-water environments in recent and Quaternary assemblages. High abundance of some members of the Wetzeliella complex (and other peridiniaceans) also indicates in broad terms a shallow-water, marine to estuarine environment. Good man suggested that the distribution patterns mainly reflected an inshore-offshore trend rather than a latitudinal-climatic trend. Chateauneuf (1980), in a study of dinoflagellates from the lower Oligocene of the Paris Basin, noted that Gerdiocysta conopea was abundant in normal marine environments that also contained more species (24-30), whereas Wetzeliella gochtii predominated in brackish-water or lower-salinity environments, where the species diversity was low.

Some palynologists have studied modern dinoflagel 
late cyst distribution patterns and arrived at similar conclusions. For example, Müller (1959) reported in his investigation of the recent Orinoco Delta and shelf sediments that specimens of "Hystrix" (i.e., probably chorate dinoflagellate cysts) were absent in the littoral zone opposite the Orinoco Delta and were concentrated mainly in the eastern Gulf of Paria, close to the Trinidad shore, where Müller assumed that optimal conditions for the development of "Hystrix" prevailed, that is, the presence of clear water with a salinity of 18 to 22 per cent and a temperature up to $29^{\circ} \mathrm{C}$. Müller also pointed out that the "Hystrix" specimens from this part of the gulf were larger and better developed than those from the outer shelf, and additionally that foraminifera flourished there. Davey and Rogers (1975) studied the palynomorph distributions in recent sediments from the continental shelf and slope off South West Africa and found that Spiniferites ramosus was associated with cold upwelling water, and Operculodinium centrocarpum was associated with warmer water masses.
Dale (1983) concluded that recent cyst distributions suggested no general trend in functional morphology, that is, they do not support the view that chorate cysts reflect the need for greater flotation, in that they become well developed under warm-water conditions. Thus he concluded that recent cyst morphology seemed not to be a good indicator of palaeoenvironment. However, the use of various palaeontological and sedimentological criteria may yield reliable palaeoenvironmental interpretations.

We suggest that the six Oppel zones defined here have not only stratigraphical significance but also palaeoecological meaning; evolution is related to the environment. The late Cretaceous to early Tertiary western Tarim Basin was a gulf at the eastern end of the northern branch of the Tethys (Text-Fig. 6). The first transgression of this area began in Cenomanian times and resulted in the nearshore, shallow-water deposition of brown and red, mostly arenaceous mudstones in the lower part of the Kukebai Formation (Text-Fig. 7). Foraminiferal assemblages are dominated by arenaceous forms, notably

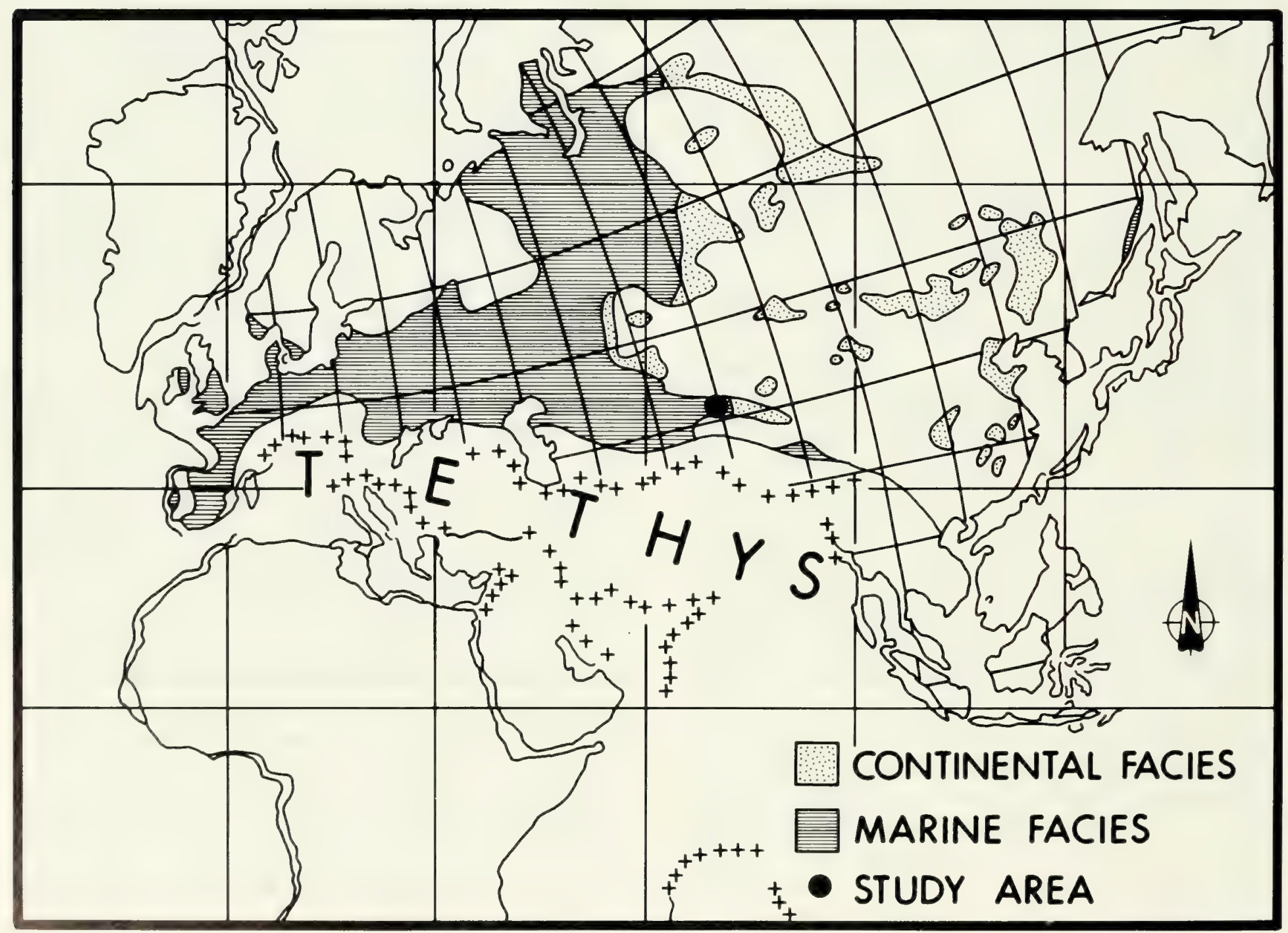

TEXT-FIG. 6. Late Cretaceous palaeogeographical map of Eurasia (from Smith and Briden, 1977; Wang et al., 1980). 
Migrous sp., with smaller numbers of perforate calcareous forms such as Hedbergella cretacea (Hao, Zeng, and $\mathrm{Li}, 1982: 29)$. Other invertebrate fossils are very rare. Dinoflagellates have not been recovered from this part of the Kukebai Formation; their apparent absence is presumably due to turbulence and turbidity and salinity changes, which precluded their growth or accumulation in the generally coarse-grained sediments. In Cenoma- nian to Turonian times, monotonous argillaceous sediments of the middle part of the Kukebai Formation were deposited in a stable shelf environment. In these sediments, dinoflagellate assemblages are dominated by proximochorate cysts, such as Cyclonephelium brevispinatum and Palaeohystrichophora infusorioides, which are thin-spined forms, indicating presumably the early stage of marine transgression or shallow-water

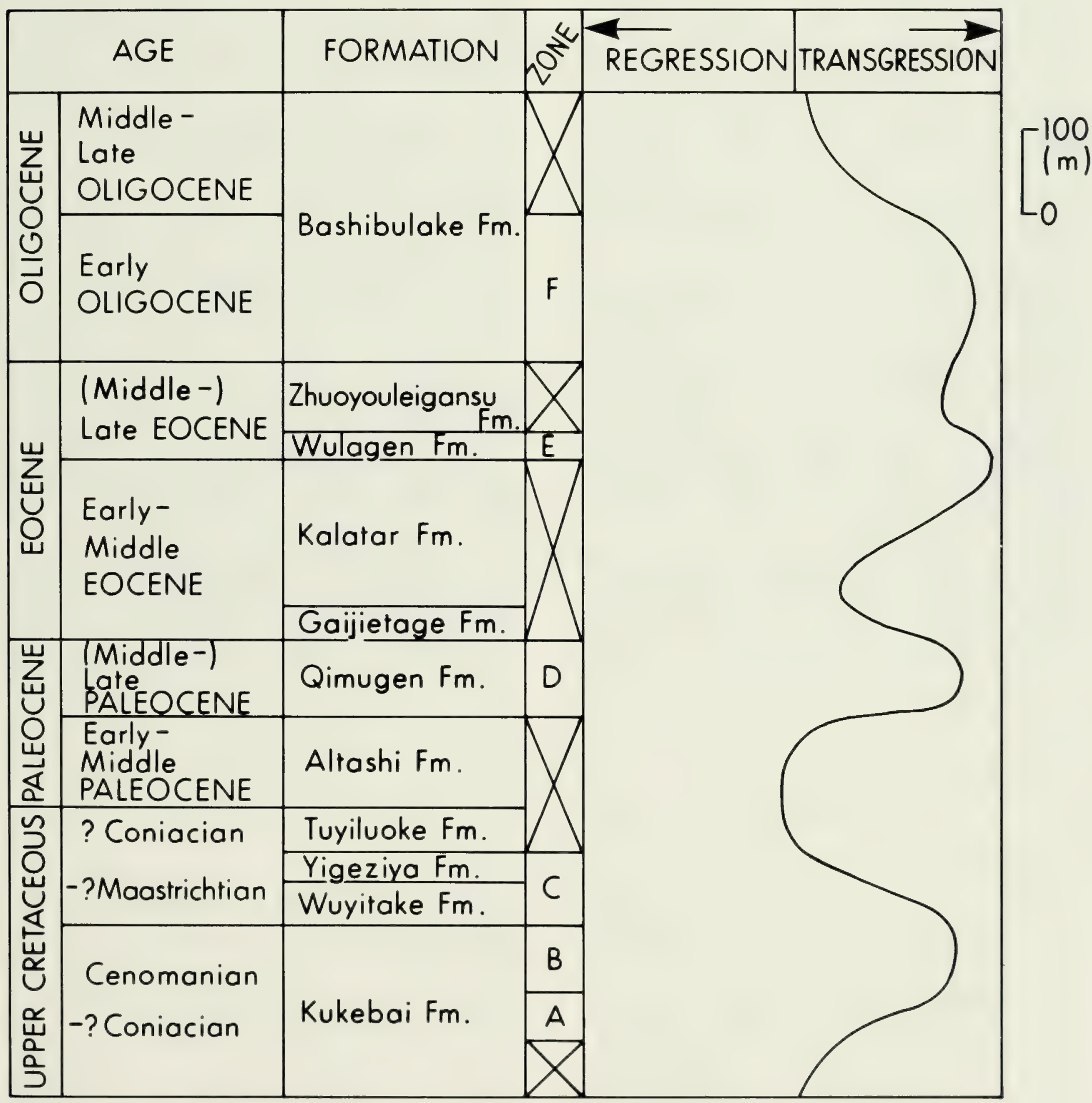

TEXT-FIG. 7. Schematic diagram indicating presumed transgressions and regressions in the study area during the late Cretaceous to early Tertiary, based on the information from sediments and foraminifera and dinoflagellates contained therein. 
conditions. At the same time, foraminifera became abundant and were dominated by arenaceous forms, such as Ammobaculites sp. and Migros sp. (Hao, Zeng, and $\mathrm{Li}, 1982: 29$ ). Therefore, it is possible that shallow marine conditions prevailed at that time.

Afterwards, during the deposition of the upper part of the Kukebai Formation (Turonian-Coniacian or Turonian-Santonian), the most abundant and diverse dinoflagellate assemblages occurred in Zone B in the Upper Cretaceous, which is represented by skolochorate and spiniferate cysts (e.g., Oliogosphaeridium pulcherrimum, $O$. complex, Spiniferites ramosus) together with a variety of cavate deflandreoid cysts, such as Alterbidinium, Eurydinium, and Isabelidinium. Arenaceous foraminifera were replaced at that time by calcareous perforate forms, such as Nonion, Nonionella, and Cibicides. All these observations indicate that the upper part of the Kukebai Formation appears to represent the peak of the late Cretaceous transgression (Text-Fig. 7).

The post-Coniacian or post-Santonian regression was accompanied by increasing aridity. Restricted lagoons developed in which massive gypsum and gypsiferous sandstone and mudstone were deposited as the Wuyitake and Yigeziya formations. Foraminifera became sparse, with only Ammobaculites sp. cf. A. subplanatus and Haplophragmium planulum occurring. Dinoflagellate assemblages, in which Canningia reticulata dominate, became less diverse and abundant. All this information indicates that the Wuyitake and Yigeziya formations represent a regressive deposit.

Regression continued to the end of Cretaceous times and the beginning of the Paleocene, resulting in the numerous lacunae in the Yigeziya Formation and the deposition of the hypersaline sediments of the Tuyiluoke Formation. The latter formation contains no invertebrate fossils and only a few poorly preserved dinoflagellate cysts, such as Alterbidinium sp., Diconodinium sp., Eucladinium sp., Palaeohystrichophora infusorioides, Palaeoperidinium sp., and Trithyrodinium sp., in the lower part. In its upper part, one sample from the Tuyiluoke Formation contains Pediastrum sp. (probably lacustrine) and rare pollen grains of Chenopodipollis sp. and Ephedripites sp., which together with the lithology of the Tuyiluoke Formation and its lack of fossils suggests an arid and oxidizing palaeoenvironment. Thus the latest Cretaceous regression in the Tarim Basin parallels the major regressions in the Maastrichtian to early Paleocene elsewhere in Europe and North America. The early or early to middle Paleocene is represented by the massive gypsum, gypsiferous mudstones, and dolomitic limestones of the Altashi Formation. These were deposited in highly restricted lagoons under arid conditions. Only a few poorly preserved dinoflagellates occur in this interval, accompanied by a few pollen grains of Chenopodi- pollis and Ephedripites.

The Qimugen Formation (late Paleocene or middle to late Paleocene) represents the second major transgression from the Tethys in the interval studied (Text-Fig. 7). The foraminiferal assemblages are dominated by Spiroplectammina and Textularia, the latter indicating (if comparisons with modern assemblages are valid) relatively quiet marine waters of 31 to 32 parts per thousand salinity and depths ranging from subtidal to 20 to $50 \mathrm{~m}$ (Hao, Zeng, and $\mathrm{Li}, 1982: 41$ ). The rich dinoflagellate assemblages are characterized by abundant skolochorate and spiniferate cysts, such as Achomosphaera ramulifera, Spiniferites ramosus subsp. multibrevis, $S$. ramosus subsp. granosus, Araneosphaera araneosa, and abundant Ceratiopsis speciosa, indicating optimal offshore conditions for both dinoflagellates and foraminifera.

The late Paleocene transgression might be of restricted geographical extent. This is evidenced by the fact that in its type section at Qimugen, the Qimugen Formation contains a diversity and abundance of dinoflagellates, whereas at Simuhana the abundance and diversity are considerably reduced and at Wuluokeqiate dinoflagellates are absent.

The overlying lower Eocene Gaijietage Formation, a lagoonal gypsiferous mudstone unit, may represent another regression. It contains no dinoflagellates or acritarchs, but foraminifera are represented by a few species, such as Nonion laevis and Cibicides lobatulus, which are restricted to the Kuzigonsu area (Text-Fig. 1) but are absent elsewhere in the study area.

The middle Eocene Kalatar Formation is mainly composed of hard and thick-bedded to massive arenaceous and rudaceous limestones and contains oysters and other pelecypods, marine ostracods, and foraminifera. The foraminifera are neither abundant nor diverse, being chiefly Nonion and Cibicides. Dinoflagellate assemblages comprise a small number of poorly preserved cysts of Apectodinium sp., Deflandrea sp., Kisselovia sp., Thalassiphora sp., and Wetzeliella sp. The preceding observations suggest nearshore marine or estuarine conditions. Therefore the next transgression probably started in the middle Eocene.

During the middle to late Eocene, the argillaceous sediments and carbonates of the Wulagen Formation were mainly deposited; they contained oysters, marine ostracods, and foraminifera. The foraminifera are benthonic calcareous perforate forms dominated by Nonion, Anomalinioides, and Cibicides (Hao, Zeng, and $\mathrm{Li}$, 1982:35), which, according to Hao, Zeng, and $\mathrm{Li}$ (1982:42), indicate that this area was in the upper subtidal zone. The dinoflagellate assemblages are abundant and diverse ( 85 species and subspecies encountered), dominated in both diversity and quantity by skolochorate cysts, such as Areosphaeridium and Homotryblium; 
spiniferate cysts, such as Spiniferites and Achomosphaera; and trabeculate cysts, such as Adnatosphaeridium and some species of Glaphyrocysta. It is likely that marine circulation and connections were good at this time, given that more than half of the species encountered are also known in coeval assemblages from Europe and Australia. The circumstances in the late Eocene were optimal for abundant foraminifera, dinoflagellates, and some other invertebrates.

The latest Eocene Zhuoyouleigansu Formation represents lithologically more restricted lagoonal conditions. Dinoflagellates are unknown, foraminifera are restricted to one section, and other invertebrate fossils are absent in this interval.

During the early Oligocene there was a rise in sea level so that the restricted lagoonal environment became open, normal marine again, with oysters, Pecten, and other bivalves, gastropods, worms, ostracods, and foraminifera (Hao, Zeng, and Li, 1982:42). Abundant foraminifera dominated by benthonic calcareous perforate forms such as Cibicidoides, Spiroplectammina, Baggina, Cibicides, and Heterolepa, indicate a warm, quiet, and stable marine environment (Hao, Zeng, and Li, 1982:42). However, the early Oligocene dinoflagellate assemblages, which are less diverse and less abundant than those of the late Eocene and are dominated by thick-walled cavate and chorocavate cysts, such as Deflandrea, Wetzeliella, and Kisselovia, seem to suggest that the water mass was shallower and less stable than that of the middle to late Eocene (Text-Fig. 7).

Later in the middle to late Oligocene the deposits in the western Tarim Basin became more arenaceous. Many sedimentary structures such as undulose-bedding, ripple marks, and cross-bedding occur in the upper part of the Bashibulake Formation, and those invertebrate fossils discovered in the lower part of the Bashibulake Formation disappear. Foraminifera become sharply reduced in both diversity and abundance. This suggests that the present area changed from the outer zone to the inner zone of the inner neritic environment from the early Oligocene to late Oligocene.

Thus, in summary, there were three major transgres sions (see Text-Fig. 7) in late Cretaceous and Paleogene times in the Tarim Basin; these occurred in (1) Cenomanian to Turonian to Santonian (the upper part of the Kukebai Formation), (2) late or middle to late Paleocene (the Qimugen Formation), and (3) late or middle to late Eocene times (the Wulagen Formation).

During each transgression, when less arenaceous and gypsiferous sediments were deposited, the dinoflagellate assemblages were diverse and abundant. Among these assemblages skolochorate, spiniferate, and trabeculate cysts usually dominated. Simultaneously, the foraminifera were dominated by calcareous perforate forms. In contrast, during each regression, when the deposits were more arenaceous and gypsiferous, the dinoflagellate assemblages were less diverse and abundant; skolochorate, spiniferate, and trabeculate cysts became dramatically reduced in numbers. The calcareous perforate foraminifera were either replaced by the arenaceous forms or became reduced in size and diversity. In restricted lagoonal facies characterized by massive gypsum or hypersaline sediments, both foraminifera and dinoflagellates were sparse or completely absent. Thus, the gross characteristics of the dinoflagellate assemblages appear to be environmentally controlled.

The final marine regression in the Tarim Basin began in the late Oligocene and culminated in the Miocene uplift of the Himalayan orogeny. The Tarim Basin was finally cut off from the Tethys in Neogene times.

\title{
Systematics
}

\section{LIST OF DINOFLAGELLATE AND ACRITARCH TAXA ENCOUNTERED}

\author{
Division Pyrrhophyta Pascher, 1914 \\ Class Dinophyceae Fritsch, 1929 \\ Order Peridiniales Haeckel, 1894 \\ Suborder Rhaetogonyaulacineae Norris, 1978
}

\section{Family Pseudoceratiaceae Eisenack, emend. Dörhöfer and Davies, 1980}

Canningia colliveri Cookson and Eisenack, 1960b (Pl. 1, fig. 1)

Canningia (?) minor Cookson and Hughes, 1964 (PI. 1, fig. 2)
Canningia reticulata Cookson and Eisenack, 1960b; emend. Below, 1981 (Pl. 1, figs. 3-5)

Canningia kukebaiensis sp. nov. (PI. 1, figs. 6-8)

Cerbia formosa sp. nov. (PI. 1, figs. 9,10)

Heterosphaeridium sp.

Odontochitina costata Alberti, 1961 (Pl. 1, fig. 11)

Odontochitina operculata (O. Wetzel, 1933a) Deflandre 
and Cookson, 1955 (Pl. 1, figs. 12,13)

Odontochitina porifera Cookson, 1956 (Pl. 1, fig. 14)

Odontochitinopsis molesta (Deflandre, 1937) Eisenack, 1961 (Pl. 1, fig. 15)

Family Areoligeraceae Evitt, emend. Sarjeant and Downie, 1966

Cyclonephelium brevispinatum (Millioud, 1969) Below, 1981 (Pl. 1, figs. 16-18)

Cyclonephelium compactum Deflandre and Cookson, 1955 (Pl. 1, fig. 19)

Cyclonephelium distinctum Deflandre and Cookson, 1955 (PI. 1, fig. 20)

Cyclonephelium (?) hystrix (Eisenack, 1958) Davey, 1978
(PI. 1, figs. 21,22)

Cyclonephelium paucispinum Davey, 1969 (Pl. 1, fig. 23)

Cyclonephelium vannophorum Davey, 1969 (PI. 2, fig. 1)

Glaphyrocysta exuberans (Deflandre and Cookson, 1955) Stover and Evitt, 1978 (Pl. 2, figs. 2,3)

Glaphyrocysta intricata (Eaton, 1971) Stover and Evitt, 1978 (Pl. 2, fig. 4)

Glaphyrocysta laciniiformis (Gerlach, 1961) Stover and Evitt, 1978 (Pl. 2, fig. 5)

Glaphyrocysta ordinata (Williams and Downie, 1966a) Stover and Evitt, 1978 (Pl. 2, fig. 6)

Glaphyrocysta pastielsii (Deflandre and Cookson, 1955) Stover and Evitt, 1978 (Pl. 2, figs. 7,8)

Membranophoridium aspinatum Gerlach, 1961 (PI. 2, figs. 9-13)

\section{Suborder Gonyaulacystineae Norris, 1978}

Family Gonyaulacystaceae Sarjeant and Downie, emend. Sarjeant and Downie, 1966

Gonyaulacysta sp. (P1. 2, figs. 14-16)

Millioudodinium (?) aequum sp. nov. (Pl. 2, figs. 17-19)

Millioudodinium (?) venulosum sp. nov. (Pl. 3, figs. 1,2)

Millioudodinium sp. (Pl. 3, fig. 3)

Pterodinium cingulatum (O. Wetzel, 1933b) Below, 1981

(Pl. 3, fig. 4)

Family Apteodiniaceae Eisenack, emend. Sarjeant and Downie, 1974

Apteodinium conjunctum Eisenack and Cookson, 1960 (Pl. 3, fig. 5)

Apteodinium maculatum Eisenack and Cookson, 1960 (Pl. 3, fig. 6)

Chytroeisphaeridia sp. (Pl. 3, fig. 7)

Kenleyia sp. (Pl. 3, fig. 8)

Tectadodinium sp. cf. T. pellitum Wall, 1967 (Pl. 3, fig. 9)

Family Spiniferitaceae Sarjeant and Downie, emend. Sarjeant and Downie, emend. Norris, 1978

Achomosphaera crassipellis (Deflandre and Cookson, 1955) Stover and Evitt, 1978 (Pl. 3, fig. 10)

Achomosphaera mariannae (Philippot, 1949) Stover and Evitt, 1978 (PI. 3, fig. 11)

Achomosphaera ramulifera (Deflandre, 1937) Evitt, 1963 (Pl. 3, figs. 12,13)

Spiniferites supparus (Drugg, 1967) Sarjeant, 1970 (Pl. 3, fig. 14)
Spiniferites cornutus (Gerlach, 1961) Sarjeant, 1970 (Pl. 3 , figs. 15,16 )

Spiniferites cornutus subsp. normalis (Cookson and Eisenack, 1974) Lentin and Williams, 1977 (Pl. 3, fig. 17)

Spiniferites katatonos Corradini, 1973 (Pl. 3, fig. 18)

Spiniferites ramosus subsp. ramosus (Ehrenberg, 1838) Loeblich and Loeblich, 1966 (PI. 3, fig. 19)

Spiniferites ramosus subsp. granomembranaceus (Davey and Williams, 1966a) Lentin and Williams, 1973

Spiniferites ramosus subsp. granosus (Davey and Williams, 1966a) Lentin and Williams, 1973 (Pl. 3, fig. 20)

Spiniferites ramosus subsp. multibrevis (Davey and Williams, 1966a) Lentin and Williams, 1973 (PI. 3, figs. 21-26)

Spiniferites ramosus subsp. multiplicatus (Rossignol, 1964) Lentin and Williams, 1973 (Pl. 3, fig. 27)

Family Endoscriniaceae Vozzhennikova, emend. Sarjeant and Downie, 1974

Scriniodinium sp.

Samlandia chlamydophora Eisenack, 1954 (Pl. 3, figs. 28, 29)

\section{Family Cordosphaeridiaceae Sarjeant and Downie,} emend. Norris, 1978

Achilleodinium biformoides (Eisenack, 1954) Eaton, 1976 (Pl. 4, figs. 1,2) 
Achilleodinium latispinosum (Davey and Williams, 1966b) Bujak et al., 1980b (PI. 4, figs. 3,4)

Amphorosphaeridium sp.

Araneosphaera araneosa Eaton, 1976 (Pl. 4, fig. 5)

Bacchidinium polypes subsp. clavulum (Davey, 1969) Lentin and Williams, 1981 (Pl. 4, fig. 6)

Cordosphaeridium biarmatum Morgenroth, 1966 (Pl. 4, fig. 7)

Cordosphaeridium exilimurum Davey and Williams, 1966 b (Pl. 4, figs. 8,9)

Cordosphaeridium funiculatum Morgenroth, 1966 (Pl. 4, fig. 10)

Cordosphaeridium inodes subsp. longipes Hansen, 1977 (Pl. 4, figs. 11,12)

Melitasphaeridium asterium (Eaton, 1976) Bujak et al., 1980b (Pl. 4, figs. 13-15)

Melitasphaeridium pseudorecurvatum (Morgenroth, 1966) Bujak et al., 1980b

Turbiosphaera filosa (Wilson, 1967a) Archangelsky, 1969a (Pl. 4, fig. 16)

Turbiosphaera galatea Eaton, 1976 (Pl. 4, fig. 17)

\section{Family Lingulodiniaceae Sarjeant and Downie, 1974}

Coronifera minor (Yu and Zhang, 1980) comb. nov. (Pl. 4 , figs. 18-22)

Coronifera striolata (Deflandre, 1937) Stover and Evitt, 1978 (Pl. 4, fig. 23)

Coronifera sp., (Pl. 4, fig. 24)

Exochosphaeridium muelleri Yun, 1981 (Pl. 5, fig. 1)

Exochosphaeridium sp. cf. E. muelleri Yun, 1981 (PI. 5, figs. 2,3)

Exochosphaeridium phragmites Davey et al., 1966

Lingulodinium pugiatum (Drugg, 1970b) Wall and Dale, 1973 (PI. 5, fig. 4)

Kiokansium unituberculatum (Tasch, 1964) Stover and Evitt, 1978 (Pl. 5, figs. 5-7)

Operculodinium bergmannii (Archangelsky, 1969a) Stover and Evitt, 1978 (Pl. 5, fig. 8)

Operculodinium sp. (Pl. 5, fig. 9)

Protoellipsodinium sp. (PI. 5, fig. 10)

Protoellipsodinium clavulum Davey and Verdier, 1974 (Pl. 5, fig. 11)

\section{Suborder Hystrichosphaeridiineae Norris, 1978}

\section{Family Hystrichosphaeridiaceae Evitt, emend. Sarjeant and Downie, emend. Norris, 1978}

Adnatosphaeridium multispinosum Williams and Downie, 1966a (PI. 5, figs. 12,13)

Adnatosphaeridium vittatum Williams and Downie, 1966a (Pl. 5, fig. 14)

Adnatosphaeridium williamsii Islam, 1983 (Pl. 5, figs. 15, 16)

Adnatosphaeridium sp. (Pl. 5, fig. 17)

Areosphaeridium (?) actinocoronatum (Benedek, 1972) Stover and Evitt, 1978 (Pl. 5, fig. 18)

Areosphaeridium arcuatum Eaton, 1971 (Pl. 5, fig. 19)

Areosphaeridium diktyoplokum (Klumpp, 1953) Eaton, 1971 (Pl. 5, figs. 20-22)

Areosphaeridium fenestratum Bujak, 1976 (Pl. 6, figs. 1-3)

Areosphaeridium multicornutum Eaton, 1971 (Pl. 6, figs. 4,5)

Diphyes colligerum (Deflandre and Cookson, 1955) Cookson, 1965a (Pl. 6, figs. 6,7)

Diphyes cretaceum Yu and Zhang, 1980 (Pl. 6, fig. 8)

Distatodinium ellipticum (Cookson, 1965a) Eaton, 1976 (PI. 6, fig. 9)

Hystrichokolpoma cinctum Klumpp, 1953 (Pl. 6, fig. 10) Hystrichokolpoma granulata Eaton, 1976 (PI. 6, figs. 11,12)

Hystrichokolpoma rigaudiae Deflandre and Cookson,
1955 (Pl. 6, figs. 13,14)

Hystrichokolpoma salacium Eaton, 1976 (Pl. 6, fig. 15)

Hystrichokolpoma sp. cf. H. unispina Williams and Downie, 1966b (Pl. 6, fig. 16)

Hystrichosphaeridium salpingophorum Deflandre, 1935, emend. Davey and Williams, 1966b (Pl. 6, fig. 17)

Hystrichosphaeridium (?) stellatum Maier, 1959 (PI. 6, figs. 18,19)

Hystrichosphaeridium tubiferum (Ehrenberg, 1838) Deflandre, 1937, emend. Davey and Williams, 1966b (Pl. 6, fig. 20)

Hystrichosphaeridium tubiferum subsp. brevispinum (Davey and Williams, 1966b) Lentin and Williams, 1973 (Pl. 6, fig. 21)

Litosphaeridium siphoniphorum (Cookson and Eisenack, 1958) Davey and Williams, 1966b (Pl. 6, fig. 22)

Oligosphaeridium complex (White, 1842) Davey and Williams, 1966b (Pl. 6, figs. 23,24)

Oligosphaeridium sp. cf. O. irregulare (Pocock, 1962) Davey and Williams, 1969 (Pl. 7, fig. 1)

Oligosphaeridium pulcherrimum (Deflandre and Cookson, 1955) Davey and Williams, 1966b (Pl. 7, figs. 2-6)

Surculosphaeridium sp. (Pl. 7, figs. 7,8)

Systematophora ancyrea Cookson and Eisenack, 1965 (Pl. 7, figs. 9,10)

Tanyosphaeridium salpinx Norvick, 1976 (PI. 7, fig. 11)

Tanyosphaeridium sp. A (Pl. 7, figs. 12,13)

Tanyosphaeridium sp. B (PI. 7, figs. 14,15) 


\section{Family Cleistosphaeridiaceae Sarjeant and Downie, 1974}

Cleistosphaeridium diversispinosum Davey et al., 1966 (PI. 7, fig. 16)

Cleistosphaeridium (?) multifurcatum (Deflandre, 1937) Davey et al., 1969 (Pl. 7, figs. 17,18)

Cleistosphaeridium (?) multispinosum (Singh, 1964) Brideaux, 1971 (Pl. 7, fig. 19)

Cleistosphaeridium perforoconum Yun, 1981 (Pl. 7, fig. 20)

Cleistosphaeridium radiculopsis $\mathrm{sp}$. nov. ( $\mathrm{Pl}$. 7, figs. $21-23)$

Family Florentiniaceae Harker and Sarjeant, emend. Norris, 1978

Florentinia cooksoniae (Singh, 1971) Duxbury, 1980 (Pl. 7 , figs. 24,25)

Florentinia deanei (Davey and Williams, 1966b) Davey and Verdier, 1973 (Pl. 8, fig. 1)

Florentinia laciniata subsp. propria subsp. nov. (PI. 8, figs. 2-5)

Florentinia mantellii (Davey and Williams, 1966b) Davey and Verdier, 1973 (Pl. 8, figs. 6-8)

Homotryblium abbreviatum Eaton, 1976 (Pl. 8, figs. 9,10)

Homotryblium pallidum Davey and Williams, 1966b (PI. 8 , figs. 11,12 )
Homotryblium tenuispinosum Davey and Williams, $1966 \mathrm{~b}$ (Pl. 8, figs. 13,14)

\section{Family Lithodiniaceae Norris, 1978}

Alisocysta circumtabulata (Drugg, 1967) Stover and Evitt, 1978 (PI. 8, fig. 15)

Schematophora speciosa Deflandre and Cookson, 1955 (Pl. 8, fig. 16)

Family Batiacasphaeraceae Dörhöfer and Davies, 1980

Batiacasphaera hystrieosa sp. nov. (PI. 8, figs. 17-20)

Sentusidinium stipulatum $\mathrm{sp}$. nov. (Pl. 8, figs. 21,22)

\section{Family Senoniasphaeraceae Norris, 1978}

Polygonifera sp.

Trigonopyxidia ginella (Cookson and Eisenack, 1960a) Downie and Sarjeant, 1964 (PI. 8, fig. 23)

Wallodinium anglicum (Cookson and Hughes, 1964) Lentin and Williams, 1973 (Pl. 8, fig. 24)

Wallodinium lunum (Cookson and Eisenack, 1960a) Lentin and Williams, 1973 (Pl. 8, fig. 25)

\section{Family Incerta}

Polysphaeridium subtile Davey and Williams, 1966b (Pl. 8, fig. 26)

Suborder Peridiniineae Fott, emend. Bujak and Davies, 1983

Family Deflandreaceae Eisenack, emend.

Bujak and Davies, 1983

Subfamily Deflandreoideae Bujak and Davies, 1983

Alterbidinium emulatum sp. nov. (PI. 9, figs. 1,2)

Ceratiopsis albertii (Corradini, 1973) Lentin and Williams, 1977 (Pl. 9, fig. 3)

Ceratiopsis depressa (Morgenroth, 1966) Lentin and Williams, 1977 (Pl. 9, figs. 4,5)

Ceratiopsis diebelii (Alberti, 1959) Vozzhennikova, 1967 (Pl. 9, fig. 6)

Ceratiopsis leptoderma Vozzhennikova, 1963 (Pl. 9, fig. 7)

Ceratiopsis sibirica (Vozzhennikova, 1963) Lentin and Williams, 1977 (Pl. 9, fig. 8)

Ceratiopsis speciosa (Alberti, 1959) Lentin and Williams, 1977 (Pl. 9, fig. 9)

Ceratiopsis speciosa subsp. elongata subsp. nov. (PI. 9, figs. 10-12)

Ceratiopsis speciosa subsp. glabra (Gocht, 1969) Lentin and Williams, 1977 (Pl. 9, fig. 13)
Ceratiopsis sp. (Pl. 9, fig. 14)

Chatangiella serratula (Cookson and Eisenack, 1958) Lentin and Williams, 1976 (PI. 9, fig. 15)

Deflandrea andromiensis Vozzhennikova, 1967 (Pl. 9, fig. 16; Pl. 10, fig. 1)

Deflandrea sp. cf. D. arcuata Vozzhennikova, 1967 (Pl. 10, fig. 2)

Deflandrea granulata Menendez, 1965 (Pl. 10, fig. 3)

Deflandrea intrasphaerula sp. nov. (Pl. 10, figs. 4-6)

Deflandrea musculopsis sp. nov. (PI. 10, figs. 7-10)

Deflandrea oebisfeldensis Alberti, 1959 (PI. 10, figs. 11,12)

Deflandrea phosphoritica Eisenack, 1938 (Pl. 10, fig. 13-15)

Deflandrea phosphoritica subsp. australis Cookson and Eisenack, 1961

Deflandrea robusta Deflandre and Cookson, 1955 (Pl. 11, figs. 1,2)

Diconodinium multispinum (Deflandre and Cookson, 1955) Eisenack and Cookson, 1960, emend. Morgan, 1977 (PI. 11, figs. 3,4) 
Diconodinium pelliferum (Cookson and Eisenack, 1958) Eisenack and Cookson, 1960, emend. Morgan, 1977 (Pl. 11, fig. 5)

Eucladinium gambangense (Cookson and Eisenack, 1970) Stover and Evitt, 1978 (Pl. 11, figs. 6,7)

Eurydinium eyrense (Cookson and Eisenack, 1971) Stover and Evitt, 1978 (Pl. 11, figs. 8-10)

Eurydinium ingramii (Cookson and Eisenack, 1970) Stover and Evitt, 1978 (Pl. 11, fig. 11)

Eurydinium raijae (Kjellström, 1973) Stover and Evitt, 1978 (Pl. 11, figs. 12-14)

Eurydinium tempestivum sp. nov. (Pl. 11, figs. 15-17)

Isabelidinium acuminatum (Cookson and Eisenack, 1958) Stover and Evitt, 1978 (Pl. 11, fig. 18)

Isabelidinium cooksoniae (Alberti, 1959) Lentin and Williams, 1977 (Pl. 11, fig. 19)

Isabelidinium korojonensis (Cookson and Eisenack, 1958) Lentin and Williams, 1977 (Pl. 11, fig. 20)

Isabelidinium magnum (Davey, 1970) Stover and Evitt, 1978

Lentinia serrata Bujak, 1980 (Pl. 11, figs. 21-24)

Trithyrodinium evittii Drugg, 1967 (Pl. 11, figs. 25,26)

Trithyrodinium sabulum sp. nov. (Pl. 12, figs. 1-4)

\section{Subfamily Palaeocystodinioideae Bujak and Davies, 1983}

Palaeocystodinium golzowense Alberti, 1961 (Pl. 12, figs. 5,6)

Subfamily Palaeoperidinioideae Vozzhennikova emend. Bujak and Davies, 1983

Bellatudinium fusum Mao and Yu, 1981 (Pl. 12, fig. 7)

Luxadinium sp. (Pl. 12, fig. 8)

Palaeohystrichophora granulata sp. nov. (Pl. 12, figs. 9-12)

Palaeohystrichophora infusorioides Deflandre, 1935 (Pl. 12, figs. 13-16)

Palaeoperidinium cretaceum Pocock, 1962 (Pl. 12, fig. 17)

Palaeoperidinium sp. A (Pl. 12, fig. 18)

Palaeoperidinium sp. B (Pl. 12, fig. 19)

Subfamily Subtilisphaeroideae Bujak and Davies, 1983

Subtilisphaera pirnaensis (Alberti, 1959) Jain and Millepied, 1973 (Pl. 12, figs. 20,21)

Subtilisphaera scabrata Jain and Millepied, 1973 (Pl. 12, fig. 22)

Subtilisphaera senegalensis Jain and Millepied, 1973 (PI. 12, figs. 23-25)
Subfamily Wetzelielloideae Vozzhennikova, emend.

Bujak and Davies, 1983

Apectodinium paniculatum (Costa and Downie, 1976)

Lentin and Williams, 1977 (Pl. 12, figs. 26,27)

Apectodinium quinquelatum (Williams and Downie, 1966c) Costa and Downie, 1979

Kisselovia(?) clathrata (Eisenack, 1938) Lentin and Williams, 1976 (Pl. 12, fig. 28)

Kisselovia coleothrypta (Williams and Downie, 1966c) Lentin and Williams, 1976 (Pl. 13, fig. 1)

Kisselovia fusiformis sp. nov. (Pl. 13, figs. 2-4)

Kisselovia wulagenensis sp. nov. (Pl. 13, figs. 5-10)

Rhombodinium draco Gocht, 1955 (Pl. 13, fig. 11; Pl. 14, figs. 1-3)

Rhombodinium longimanum Vozzhennikova, 1967 (Pl. 14, fig. 4)

Wetzeliella articulata Eisenack, 1938 (Pl. 14, figs. 5-7)

Wetzeliella crassa sp. nov. (Pl. 15, figs. 1,2)

Wetzeliella gochtii Costa and Downie, 1976 (Pl. 15, figs. 3,4)

Wetzeliella hampdenensis Wilson, 1967b (Pl. 15, fig. 5)

Wetzeliella sp. cf. W. symmetrica Weiler, 1956

Wetzeliella sp. A (Pl. 15, figs. 6,7)

\section{Subfamily Incertae}

Talimudinium scissurum gen. et sp. nov. (Pl. 15, figs. 8-13)

Family Protoperidiniaceae Bujak and Davies, 1983 Subfamily Senegalinioideae Bujak and Davies, 1983

Phelodinium anisos sp. nov. (Pl. 15, figs. 14-16)

Phelodinium pachyceras Liengjarern, Costa, and Downie, 1980 (Pl. 15, fig. 17)

Phelodinium pumilum Liengjarern, Costa, and Downie, 1980 (Pl. 15, figs. 18,19)

Subfamily Protoperidinioideae Bujak and Davies, 1983

Lejeunecysta hyalina (Gerlach, 1961, emend. Kjellström, 1972) Artzner and Dörhöfer, 1978 (Pl. 15, figs. 20,21)

Lejeunecysta sp. (Pl. 16, fig. 1)

Sumatradinium hispidum (Drugg, 1970a) Lentin and Williams, 1976 (PI. 16, figs. 2,3)

\section{Subfamily Incertae}

Pseudoalterbia concinna gen. et sp. nov. (PI. 16, figs. 4-6) Xuidinium laevigatum gen. et. sp. nov. (Pl. 16, figs. 7-11) 


\section{Suborder Incertae}

\section{Family Ceratocoryaceae Stein, 1883}

Thalassiphora bononiensis Corradini, 1973 (PI. 16, fig. 12)

Thalassiphora delicata Williams and Downie, 1966a, emend. Eaton, 1976 (Pl. 16, fig. 13)

Thalassiphora flammea Cookson and Eisenack, 1967

Thalassiphora patula (Williams and Downie, 1966a)
Stover and Evitt, 1978 (Pl. 16, fig. 14)

Thalassiphora pelagica (Eisenack, 1954) Eisenack and Gocht, 1960 (PI. 16, figs. 15,16)

\section{Family Incertae}

Fromea staveia Elsik, 1977 (Pl. 16, fig. 17)

\section{Group Acritarcha Evitt, 1963}

Sphaeromorphitae Downie, Evitt, and Sarjeant, 1963

Granodiscus granulatus Mädler, 1968 (Pl. 16, figs. 18,19) Leiosphaeridia hyalina (Deflandre, 1941) Downie and Sarjeant, 1963 (Pl. 16, figs. 20,21)

Acanthomorphitae Downie, Evitt, and Sarjeant, 1963

Micrhystridium sp. cf. M. castanium Valensi, 1953 (Pl.16, figs. 22,23)
Pteromorphitae Downie, Evitt, and Sarjeant, 1963

Pterospermella harti (Sarjeant, 1960) Eisenack, 1972 (Pl. 16, fig. 24)

Pterospermella australiensis (Deflandre and Cookson, 1955) Eisenack, 1972 (Pl. 16, fig. 25)

\section{GENERAL REMARKS}

\section{Terminology}

The terminology employed in the following descriptions follows that of Lentin and Williams (1976), Norris (1978), Stover and Evitt (1978), and Sarjeant (1982), unless otherwise specified.

\section{Classification}

The suprageneric classification used here is based largely on that of Artzner et al. (1979) and Dörhöfer and Davies (1980), with modifications of Peridineaceans suggested by Bujak and Davies (1983).

\section{Preservation and Designations of Slides and Specimens}

All slides are stored presently in the Department of
Geology, University of Toronto, but will be deposited for permanent curation in the micropalaeontology collection in the Department of Invertebrate Palaeontology of the Royal Ontario Museum, Toronto. In referring to individual specimens, a designation such as "WG-14; $\mathrm{A}_{2}$; $58.0 / 99.5^{\prime}$ is given; the sample number (WG-14) is indicated first (WG - Wuluokeqiate section, QF Qimugen section, and SM - Simuhana section), the slide number $\left(\mathrm{A}_{2}\right)$ is given next " $" \mathrm{~A}$ " and " $\mathrm{B}$ " represent main slides; " $G$ " represents reference slides), and the coordinates $(58.0 / 99.5)$ are given last. The coordinates are valid for Leitz Dialux microscope no. 553276 in the Palynology Laboratory of the Department of Geology, University of Toronto. 


\title{
Detailed Systematic Descriptions and Remarks
}

\author{
Family Pseudoceratiaceae
}

\section{Genus Canningia Cookson and Eisenack, 1960b}

Canningia kukebaiensis sp. nov.

Pl. 1, figs. 6-8

\section{DERIVATION OF NAME}

Named for Kukebai Formation, Upper Cretaceous, Tarim Basin, Xinjiang Province, China.

\section{HOLOTYPE}

WG-20; A $_{4} ; 45.1 / 101.3$. Kukebai Formation, Wuluokeqiate section (late Cretaceous).

\section{PARATYPE}

WG-20; $\mathrm{A}_{1} ; 47.0 / 99.2$. For other details see holotype.

\section{DIAGNOSIS}

Cyst proximate, in dorsoventral view typically broadly ellipsoidal. Apical prominence protruding slightly from outline in one end; antapical end rounded or weakly diverging into two blunt lobations. Autophragm thin, granulate, with numerous short nontabular isolated spines. Archeopyle apical, type (tA) $)_{a}$ or (tA).

\section{DESCRIPTION}

Cyst subspherical to broadly ellipsoidal. Length and breadth of cyst almost equal, or latter slightly longer. Apical prominence short ( 1 to $3 \mu \mathrm{m}$ ), protruding indistinctly from outline. Antapex rounded or with slight concavity between two weak antapical lobations. Autophragm thin and readily folded, folds usually trending approximately parallel to margin of cyst. Granulate wall surface covered with simple solid acuminate spines, 1 to $5 \mu \mathrm{m}$ long, 1 to $2 \mu \mathrm{m}$ across at their bases, and spaced 3 to $6 \mu \mathrm{m}$ apart. Archeopyle suture a zigzag line, with accessory sutures indicating six precingular plates. Operculum typically but not consistently attached. Cingulum usually indiscernible. Sulcal notch offset to the left. Indication of tabulation, other than archeopyle, absent.

\section{DIMENSIONS}

Length (including operculum) 46 to $54 \mu \mathrm{m}$ (holotype 48 $\mu \mathrm{m}$ ), width 45 to $61 \mu \mathrm{m}$ (holotype $58 \mu \mathrm{m}$ ); 6 specimens measured.

\section{STRATIGRAPHIC RANGE}

Kukebai Formation; common in Zone B of Wuluokeqiate section; Turonian to Coniacian or to Santonian.

\begin{abstract}
DISCUSSION
Canningia kukebaiensis differs from some other species of Canningia in having a subspherical to broadly ellipsoidal cyst with a small indistinct apical prominence and in its possession of a granulate autophragm covered with short, isolated, solid, and acuminate spines. C. colliveri (Cookson and Eisenack, 1960b) has a cyst somewhat longer than broad, and its surface is granular or closely to sparsely spinate. C. minor (Cookson and Hughes, 1964) has a scabrate rather than granulate and spinate surface. C. scabrosa (Cookson and Eisenack, 1970) differs from $C$. kukebaiensis in having an irregular outline and some very short and narrow hairlike appendages.
\end{abstract}

\section{Genus Cerbia Below, 1981}

Cerbia formosa sp. nov.

Pl. 1, figs. 9, 10; Text-Fig. 8

\section{DERIVATION OF NAME}

From the Latin formosus, beautiful, with reference to the beautiful processes that are characteristic of this species.

\section{HOLOTYPE}

QF-82; $\mathbf{A}_{4} ; 39.3 / 104.6$. Wulagen Formation, Qimugen section (upper Eocene).

\section{PARATYPE}

QF-82; $\mathrm{A}_{4} ; 38.2 / 100.3$. For other details see holotype.

\section{DIAGNOSIS}

Cyst proximate to proximochorate, dorsoventrally compressed, with an apical prominence. Antapical end either rounded or slightly concave. Processes penitabular, slender, and sinuous, partly connected proximally forming arcuate and soleate complexes; mostly acuminate, capitate, and bifurcate, seldom trifurcate distally. Archeopyle apical, type (4A); operculum typically detached but in situ. Archeopyle suture zigzag, with accessory sutures indicating six precingular plates. Cingulum slightly levorotatory, indicated by alignment of processes. Sulcus broader towards antapex; sulcal notch offset to left on ventral surface. Tabulation indicated by penitabular processes, gonyaulacacean; posssible formula of $4^{\prime}, 6^{\prime \prime}$, $\mathrm{XC}, 6^{\prime \prime \prime}, \mathrm{lp}, 1^{\prime \prime \prime}$.

\section{DESCRIPTION}

Ambitus rounded pentagonal to rounded biconical, prolonged into an obtuse and short tapering apical horn. 
Hypotract either semicircular or, more commonly, with two poorly developed, unequal antapical lobes; left one slightly longer than right one. Processes relatively long (usually 6 to $8 \mu \mathrm{m}$, sometimes up to 10 to $12 \mu \mathrm{m}$ ), narrow (usually 0.5 to $1 \mu \mathrm{m}$ ), sinuous, delicate; usually secondarily flattened in random orientation. Plate boundaries usually obscured. Cingulum delineated by processes about 8 to $10 \mu \mathrm{m}$ in breadth.

\section{DIMENSIONS}

Length (including operculum) 65 to $68 \mu \mathrm{m}$ (holotype 65 $\mu \mathrm{m}$ ), width 41 to $68 \mu \mathrm{m}$ (holotype $63 \mu \mathrm{m}$ ); 20 specimens measured.

\section{STRATIGRAPHIC RANGE}

Wulagen Formation to Bashibulake Formation, Zones E to F; abundant in Qimugen section, rare in Wuluokeqiate section; late Eocene to early Oligocene.

\section{DISCUSSION}

Cerbia formosa is closely comparable to $C$. tabulata (Davey and Verdier, 1974), but the latter differs in having short, stout, capitate processes, which are rarely branched distally; in $C$. formosa the processes are long, slender, curved, and frequently branched. In adddition, the processes of $C$. formosa are less clearly tabular than those of $C$. tabulata.
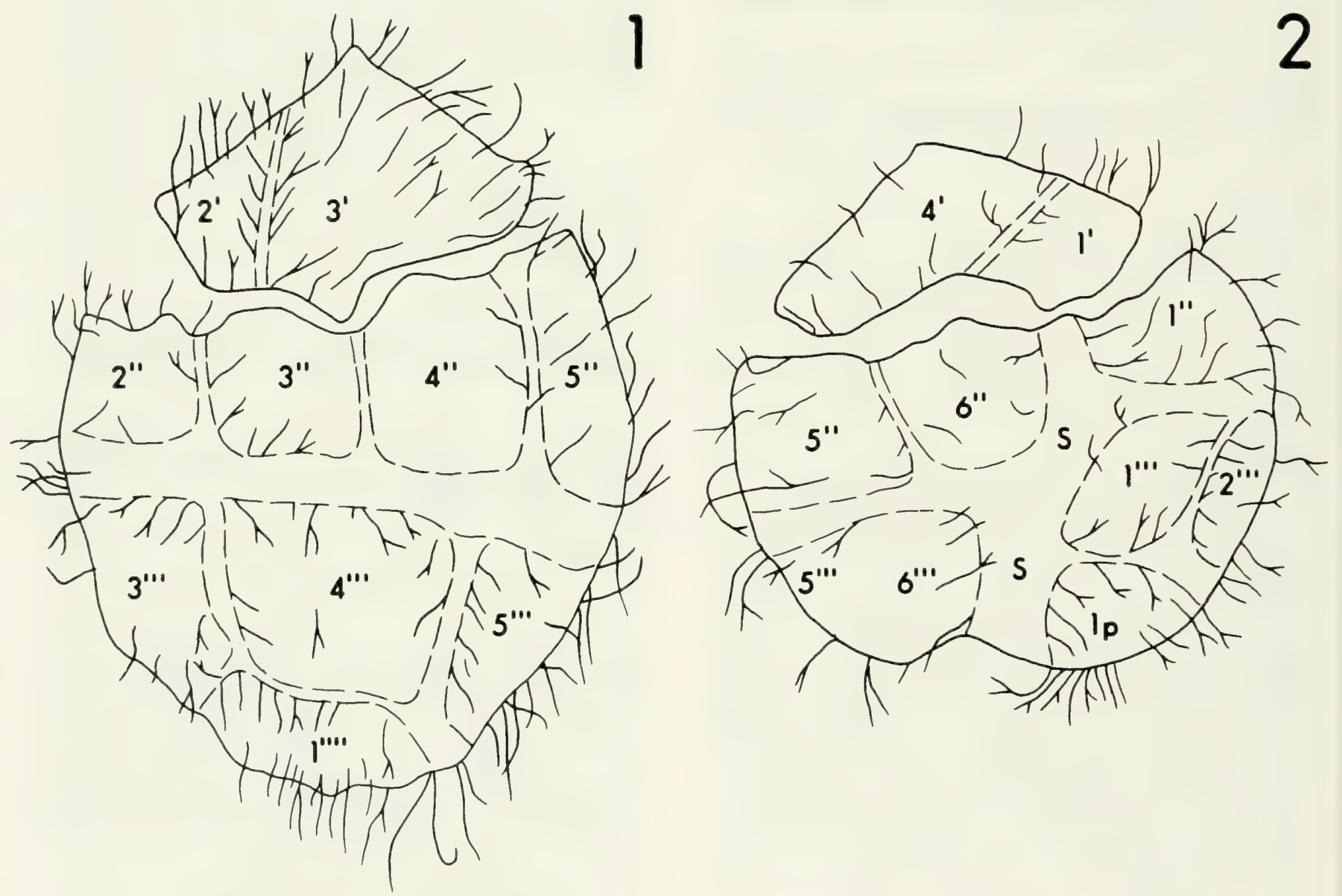

TEXT-FIG. 8. Morphology and tabulations of the paratype (1, QF-82; A4; 38.2/100.3) and holotype (2, ventral view, QF-82; $\left.\mathrm{A}_{4} ; 39.3 / 104.6\right)$ of Cerbia formosa sp. nov. 


\section{Family Areoligeraceae}

\section{Genus Cyclonephelium Deflandre and Cookson, 1955}

\section{Cyclonephelium (?) hystrix (Eisenack, 1958)}

\section{Davey, 1978}

Pl. 1, figs. 21,22

Tenua hystrix Eisenack, 1958:410, pl. 23, figs. 1-4; text-fig. 10

Tenua hystricella Eisenack, 1958:411, pl. 23, figs. 5-7

Cyclonephelium hystrix (Eisenack) Davey, 1978:894

\section{DESCRIPTION}

Cyst dorsoventrally flattened, truncated-circular to semicircular in shape with no apical plates, usually more or less asymmetrical. Wall suriace covered with stout, rigid, and densely and uniformly distributed nontabular processes; expanded proximally and slightly expanded or capitate distally; usually 1 to $2 \mu \mathrm{m}$ (rarely up to $5 \mu \mathrm{m}$ ) long, 0.5 to $2 \mu \mathrm{m}$ wide. Archeopyle apical, type (tA). Operculum usually detached; archeopyle suture zigzag with accessory sutures indicating six precingular plates.

\section{DIMENSIONS}

Width 43 to $73 \mu \mathrm{m} ; 17$ specimens measured.

\section{STRATIGRAPHIC RANGE}

Kukebai Formation to Wuyitake Formation; common in Zone $\mathrm{B}$ and rare in Zone $\mathrm{C}$ of Wuluokeqiate section; late Cretaceous.

\section{DISCUSSION}

The present specimens are here attributed questionably to Cyclonephelium hystrix (Eisenack) Davey, 1978; they are very similar to the type material as illustrated by Eisenack $(1958,1971)$, particularly in the nature of their processes.

Sarjeant and Stover (1978) reviewed Tenua and Cyclonephelium and noted that "a typical specimen of Tenua hystrix can be described briefly as exhibiting the following features: a fairly dense covering of short, solid, generally simple processes that may be somewhat more widely spaced, as well as somewhat shorter, in the middorsal and midventral areas." As a result a new combination Cyclonephelium hystrix (Eisenack) Sarjeant and Stover was proposed then.

In the original diagnosis of Tenua hystrix, however, Eisenack (1958) made no mention of middorsal and midventral reduction in ornament, nor is such a reduction evident from his illustrations. Some specimens (e.g., Eisenack, 1958, pl. 23, figs. 1,4-6) appear to show areas of reduced ornament, but it is not clear from the illustrations whether those areas are dorsoventrally situated; indeed, the areas of apparent ornament reduction may actually result from different focus levels on the specimen. As we do not have access to the type material of this species, it is not deemed appropriate to make taxonomic changes resulting from these observations. However, we do question the generic assignation pending re-examination of the type material.

\section{Genus Membranophoridium Gerlach, 1961}

\section{Membranophoridium aspinatum Gerlach, 1961}

Pl. 2, figs. 9-13

Membranophoridium aspinatum Gerlach, 1961:199, pl. 29 , figs. 7,8

Chiropteridium aspinatum (Gerlach) Brosius, 1963:48, pl. 1, fig. 1

Chiropteridium aspinatum (Gerlach) Gocht, 1969:61, pl. 5, figs. 1-3

\section{DESCRIPTION}

Cyst proximate, dorsoventrally compressed, with a short obtuse apical horn and two more or less unequal antapical lobes or horns - the left one always larger. Central body ellipsoidal, with slightly protruding apex. Periphragm thin and membranous; its margin generally smooth to slightly sinuous, seldom bearing isolated bifurcate processes. Middorsally and midventrally appressed to endophragm (indicated by line of contact), separated elsewhere. Width of pericoel varying from 0 to $16 \mu \mathrm{m}$ in one individual. Pericoel usually complete. Endophragm smooth to granulate. Archeopyle apical, type (tA) or (tA) a archeopyle suture ragged, its accessory sutures indicating six precingular plates. Operculum more commonly free than attached dorsally. Sulcal notch offset to left.

\section{DIMENSIONS}

Length 71 to $97 \mu \mathrm{m}$, width 55 to $75 \mu \mathrm{m}$; 47 specimens measured.

\section{STRATIGRAPHIC RANGE}

Wulagen Formation to Bashibulake Formation, Zones E to $\mathrm{F}$; abundant in Zone $\mathrm{E}$ of Qimugen section, rare in Zone F of Qimugen section; late Eocene to early Oligocene.

\section{DISCUSSION}

Brosius (1963) reassigned this species to the genus Chiropteridium, a change accepted by Gocht (1969). Gerlach noted in its description (1961:199) that Membra- 
nophoridium aspinatum was always found to have the operculum free in 300 specimens examined. There is only 1 specimen with an attached operculum in the illustrations of Brosius and Gocht. It is noteworthy that among 47 specimens observed, 36 have the opercula free (including 2 with a few isolated processes), and 14 have the opercula attached (including 1 with two lateral protrusions). It is suggested that the specimens of Membranophoridium aspinatum described here are intermediate forms between the genera Membranophoridium, Chiropteridium, and Senoniasphaera. These three genera may be related.

\section{Family Gonyaulacystaceae}

\section{Genus Millioudodinium Stover and Evitt, 1978}

\section{Millioudodinium (?) venulosum sp. nov.}

Pl. 3, figs. 1,2; Text-Fig. 9

Millioudodinium sp. A, Mao and Norris, 1984, pl. 1, fig. 15

\section{DERIVATION OF NAME}

From the Latin vena, vein, in reference to the fine, veinlike ornament of the autophragm of this species.

\section{HOLOTYPE}

WG-14; $A_{1} ; 40.4 / 105.5$. Kukebai Formation, Wuluokeqiate section (late Cretaceous).

\section{PARATYPE}

WG-31; $A_{2} ; 42.7 / 107.5$. Wuyitake Formation, Wuluokeqiate section (late Cretaceous).

\section{DIAGNOSIS}

Cyst proximate, typically of intermediate size, laterally flattened, ambitus elliptical to rounded rhombic. Apical horn usually short but distinct. Tabulation gonyaulacacean, indicated usually by indistinct low sutural ridges; possible formula of $4^{\prime}, ? 1 \mathrm{a}, 6^{\prime \prime}, \mathrm{XC}, 6^{\prime \prime \prime}, 1 \mathrm{p}, 1^{\prime \prime \prime}$, if determinable; faint, incomplete, slightly sinuous, and very low ridges, giving autophragm a reticulate appearance. Archeopyle precingular type (P)a or P; operculum 3 " attached along part of its two sides with 2 " and 4 ".

\section{DESCRIPTION}

Cyst ambitus elliptic to subrhombic with short (typically 4 to $7 \mu \mathrm{m}$ high), prominent apical horn. Antapex rounded, without horns or prominences. Cingulum levorotatory, usually 3 to $4 \mu \mathrm{m}$ wide, defined by sutural ridges of low to medium height. Sutural ridges indistinct, obviously gonyaulacacean. Surface between sutural ridges covered with faint, discontinuous, slightly sinuous low ridges, giving autophragm a veinlike-reticulate appearance. Omphalos often found ventrally within cyst body near boundary where cingulum and sulcus meet.

\section{DIMENSIONS}

Length 71 to $97 \mu \mathrm{m}$ (holotype $80 \mu \mathrm{m}$ ), width 55 to $75 \mu \mathrm{m}$ (holotype $62 \mu \mathrm{m}$ ); 11 specimens measured.

\section{STRATIGRAPHIC RANGE}

Kukebai Formation to Wuyitake Formation, Zones A to $\mathrm{C}$; common in Zone $\mathrm{A}$ of Wuluokeqiate section, rare in Zones $\mathrm{B}$ and $\mathrm{C}$ of Wuluokeqiate section, rare in Zone C of Simuhana section; late Cretaceous.

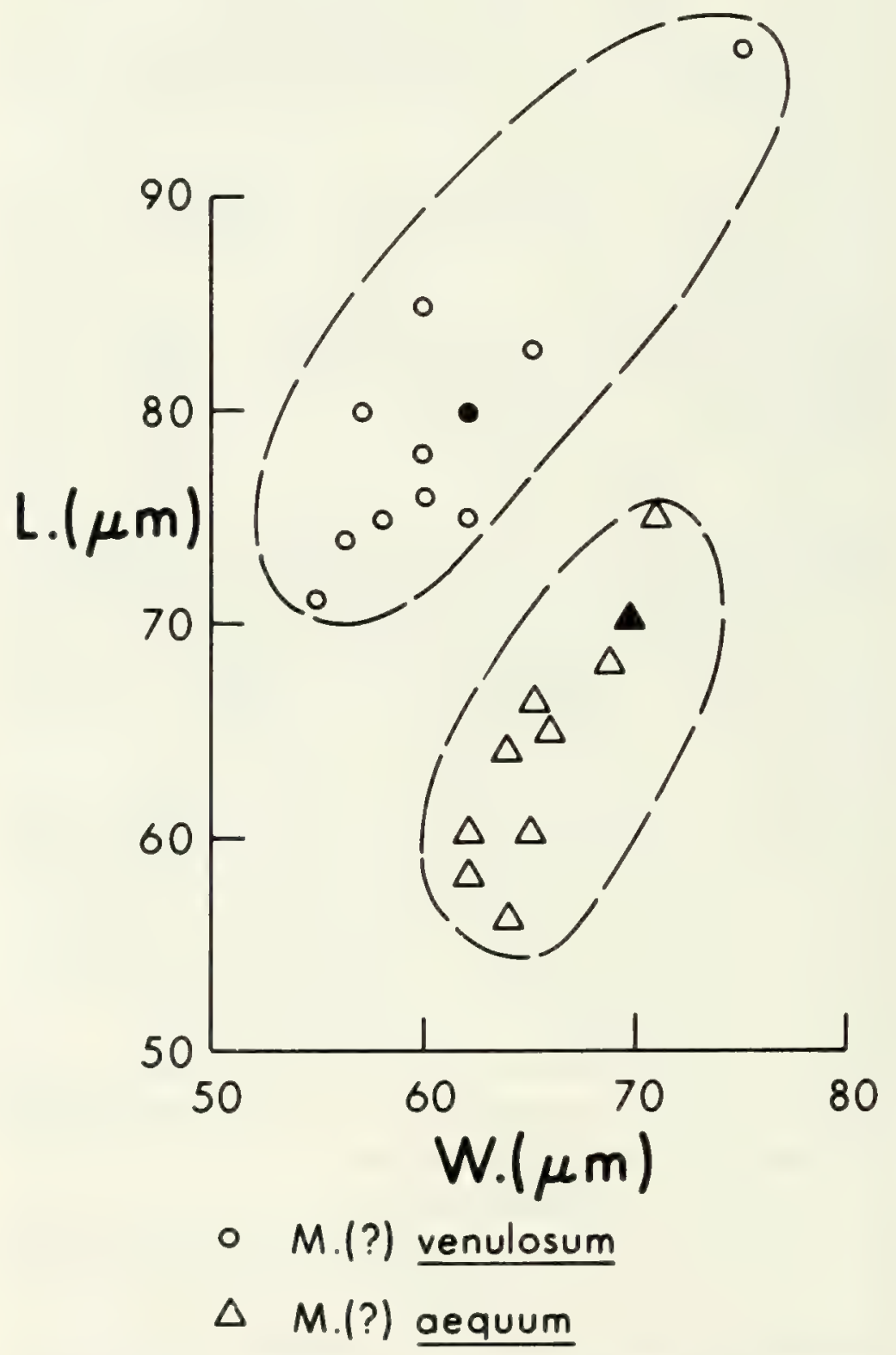

TEXT-FIG. 9. Dimensions ( $L$., length; $W$., width) of Millioudodinium(?) venulosum sp. nov. and $M$.(?) aequum sp. nov. Holotype for each species is indicated by solid circle or triangle. 


\section{DISCUSSION}

This species is characterized by having an elliptic to elongate rhombic ambitus, usually laterally flattened; very low and indistinct sutural ridges, with which some details of tabulation are interpreted with difficulty; and an autophragm with a typically imperfect microreticulate appearance between the sutures. It is assigned questionably to Millioudodinium rather than to Cribroperidinium because of the lack of some detailed information on tabulation and the lack of accessory sutures. $M$. (?) venulosum resembles $M$. globatum (Gitmez and Sarjeant, 1972), which possesses a granulate autophragm and generally well developed sutures, indicating the tabulation formula of $4^{\prime}, 1 \mathrm{a}, 6^{\prime \prime}, 6 \mathrm{c}, 6^{\prime \prime \prime}, ? 1 \mathrm{p}$, and 1 "'". M. (?) venulosum differs from $M$. (?) aequum $\mathrm{sp}$. nov. in having distinctly elongate cysts; the latter has spherical to broad spherical cysts (see Text-Fig. 9). Text-Figure 9 shows that there are almost no intermediate forms between the two species.

\section{Millioudodinium (?) aequum sp. nov.}

\section{Pl. 2, figs. 17-19; Text-Fig. 9}

Gonyaulacysta aff. episoma (Sarjeant, 1966) Yu and Zhang, 1980, pl. 1, figs. 2,3.

\section{DERIVATION OF NAME}

From the Latin aequum, equal, in reference to the fact that this species comprises cysts whose lengths are equal to their widths.

\section{HOLOTYPE}

WG-14; $A_{3} ; 41.5 / 101.9$. Kukebai Formation, Wuluokeqiate section (upper Cretaceous).

\section{PARATYPE}

WG-14; $\mathrm{A}_{2} ; 40.3 / 97.5$. Kukebai Formation, Wuluokeqiate section (upper Cretaceous).

\section{DIAGNOSIS}

Cyst proximate, typically of intermediate size $(50 \mu \mathrm{m})$, spherical with a small prominent apical horn.
Autophragm thin, readily folding along cyst margin. Tabulation gonyaulacacean, indicated by low sutural ridges; faint, veinlike low ridges between sutural ridges masking some details of tabulation. Archeopyle precingular, type (P)a, formed by loss of 3"; operculum typically attached along part of sides with 2" and/or 4", sometimes indiscernible. Cingulum helicoid.

\section{DESCRIPTION}

Cyst spherical to broadly spherical. Apical horn small but pointed, commonly 2 to $5 \mu \mathrm{m}$ long. Antapex rounded, lacking horns or prominences. Specimens randomly oriented because of sphericity, folding readily because of thin wall. Cingulum levorotatory, usually 3 to $4 \mu \mathrm{m}$ wide, bounded by ridges less than $0.5 \mu \mathrm{m}$ high. Sulcus extending from cingulum towards antapex. Sutural ridges indistinct; possible tabulation formula of $4^{\prime}, ? 1 \mathrm{a}, 6^{\prime \prime}, \mathrm{XC}$, $6^{\prime \prime \prime}, 1 \mathrm{p}, 1^{\prime \prime \prime \prime}$, if determinable. Surface between sutural ridges covered with incomplete, faint, slightly sinuous low ridges, giving the thin autophragm a veinlike reticulate appearance. Omphalos often darker in colour, spherical to subspherical in shape.

\section{DIMENSIONS}

Length 55 to $75 \mu \mathrm{m}$ (holotype $70 \mu \mathrm{m}$ ), width 62 to $71 \mu \mathrm{m}$ (holotype $70 \mu \mathrm{m}$ ); 10 specimens measured.

\section{STRATIGRAPHIC RANGE}

Kukebai Formation to Wuyitake Formation, Zones A to $\mathrm{C}$; abundant in Zone $\mathrm{A}$ of Wuluokeqiate section, rare in Zones B and C of Wuluokeqiate section and in Zone C of Simuhana section; late Cretaceous.

\section{DISCUSSION}

Millioudodinium(?) aequum closely resembles $M$.(?) venulosum but differs in having a spherical rather than an elongate cyst. Text-Figure 9 shows almost no intermediate forms between them. As with $M$. (?) venulosum, the generic assignation is questionable to Millioudodinium rather than Cribroperidinium because of the imperfect microreticulate low ridges (which are not certainly accessory ridges typical of Cribroperidinium) and the lack of detailed information on tabulation.

\section{Family Lingulodianiaceae}

\section{Genus Coronifera Cookson and Eisenack, 1958 emend. nov.}

Coronifera Cookson and Eisenack, 1958:45

Coronifera Cookson and Eisenack, emend. Davey, 1969:161

Coronifera Cookson and Eisenack, emend. Davey,
1974:47

Coronifera Cookson and Eisenack, emend. May, 1980:48

\section{TYPE SPECIES}

Coronifera oceanica Cookson and Eisenack, 1958:45, pl. 12, fig. 6, emend. May, 1980:48-49 
EMENDED DIAGNOSIS

Cyst skolochorate, midbody subspherical to ellipsoidal, bearing numerous simple, slender and acuminate, capitate or knobbed, bifurcate or trifurcate, solid or hollow nontabular processes. Processes typically closed distally and occasionally joined proximally by low folds or crests, proximally uniform in length and shape except antapical process; one large tubular open process at antapex, often terminating at a denticulate distal margin. Archeopyle precingular or combination of precingular and apical, type $(\mathrm{P})$ or $(\mathrm{tA}+\mathrm{P})$. Operculum formed variously by loss of third precingular plate $3^{\prime \prime}$, of both apical and third precingular plates, of apical plate only with third precingular plate attached along cingulum or two sides of $3^{\prime \prime}$ with $2^{\prime \prime}$ and 4 ", or of precingular plate 3 " with apical plate dislodged.

\section{DISCUSSION}

Coronifera was originally described from the Cretaceous by Cookson and Eisenack (1958:45) as follows: "Shell roughly oval in outline, with an often denticulate tubular horn at one pole and stiff pointed process at the other; the surface provided with simple or bifurcated appendages." No information about the archeopyle was given. In the first emendation of this genus by Davey (1969), the diagnosis was augmented to include the presence of an apical archeopyle and low crests joining the processes and the position of the distinctive apical and antapical processes.

Later, Davey (1974) proposed a new emendation of Coronifera, emphasizing processes that were closed distally and the presence of a precingular archeopyle rather than an apical archeopyle. These two features are considered by Stover and Evitt (1978:148) as the critical points for differentiation of Coronifera from Diphyes, the latter having an apical archeopyle and normally distally open processes. Wilson and Clowes (1980) also drew attention to the presence in Coronifera of closed processes (with the exception of the antapical one) on the cyst and continued to emphasize the precingular archeopyle as distinctive in this taxon. May (1980:48) pointed out in his emendation of Coronifera the presence of a combination archeopyle type $(\mathrm{Aa}+\mathrm{P})$. He assumed that the precingular plate 3 " "appears to be the main excystment aperture, as it is generally missing, while the apical plate is generally only dislodged."

However, Davey and Verdier (1974) drew attention to the very great range of morphological variation in $C$. oceanica, with processes on this species being simple or furcate and distally acuminate, capitate, or knobbed, with the antapical process also varying considerably in shape and size.

The material examined in the present study confirms the great range of morphologic variation in the processes and further indicates that distally open processes may occur together with the typically distally closed processes. In addition, the archeopyle of Coronifera in specimens observed by the authors is slightly different from that of May's. It may be developed in one of the following four ways: (1) only precingular plate $3^{\prime \prime}$ detached; (2) both apical and precingular 3 " plates detached; (3) apical plate detached, precingular plate partially attached; (4) precingular plate detached, apical plate partially attached. In the latter two cases, superficial examination may indicate a simple apical or simple precingular archeopyle respectively. However, detailed examination of some specimens has shown the presence of a combination archeopyle when the apical plate is detached or the precingular plate is detached.

\section{Coronifera minor ( $\mathrm{Yu}$ and $\mathrm{Zhang}, 1980$ ) comb. nov. emend.}

Pl. 4, figs. 18-22; Text-Fig. 10

Diphyes colligerum Stone, 1973 auct. non (Deflandre and Cookson, 1955) Cookson, 1965a:57, pl. 3, figs. 28,29

Diphyes minor Yu and Zhang, 1980:111, pl. 4, figs. 4,5

Diphyes minor Yu and Zhang, 1980; Mao and Norris, 1984 , pl. 1, fig. 3

\section{EMENDED DIAGNOSIS}

Cyst skolochorate, with two types of processes. Central body spherical to subspherical and of small to medium size ( 29 to $44 \mu \mathrm{m}$ in diameter). Wall thin. Periphragm smooth to finely granulate, bearing numerous processes. One large tubelike process located at antapex; process hollow, lagenate or denticulate distally, and 10 to $15 \mu \mathrm{m}$ long, 7 to $15 \mu \mathrm{m}$ wide at base. All other processes simple, slender, and acuminate; typically solid and closed distally; approximately uniform in length (about $10 \mu \mathrm{m}$ ) and appearance; expanded and occasionally joined proximally by low crests. Those processes 1 to $2 \mu \mathrm{m}$ wide basally, straight or slightly curved, and typically closed distally. Cingulum, when discernible, indicated by alignment of processes. Archeopyle variable; type $\mathrm{P}$ or $(\mathrm{tA}+\mathrm{P})$ or $\mathrm{tA}+(\mathrm{P}) \mathrm{a}$; compound operculum with precingular plate or apical plate attached.

\section{DIMENSIONS}

Central body length 30 to $45 \mu \mathrm{m}$, width 28 to $45 \mu \mathrm{m}$; process length 7 to $12.5 \mu \mathrm{m} ; 25$ specimens measured.

\section{STRATIGRAPHIC RANGE}

Kukebai Formation to Yigeziya Formation, Zones A to $\mathrm{C}$; abundant in Zone B of Wuluokeqiate section, com- 

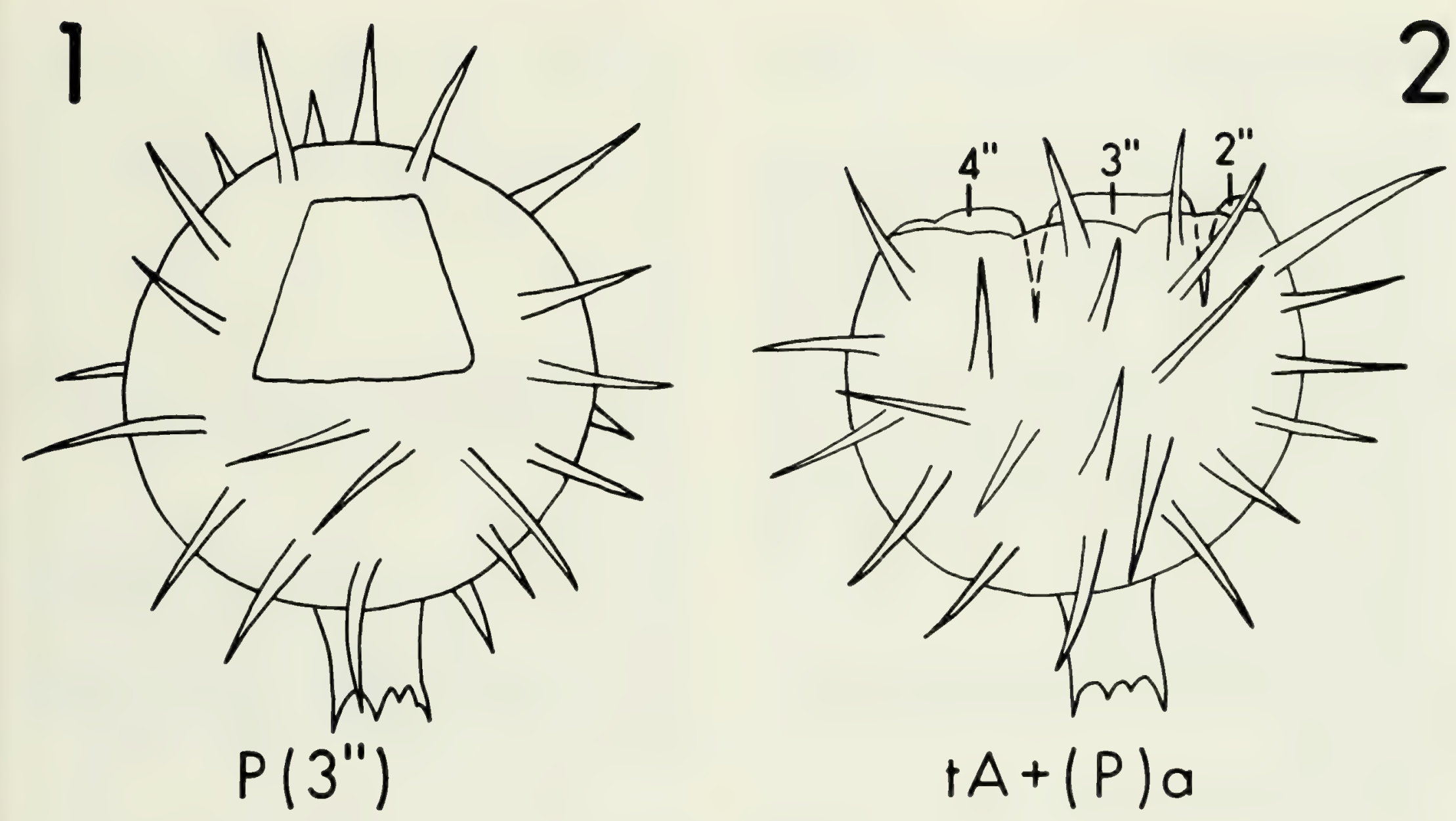

3
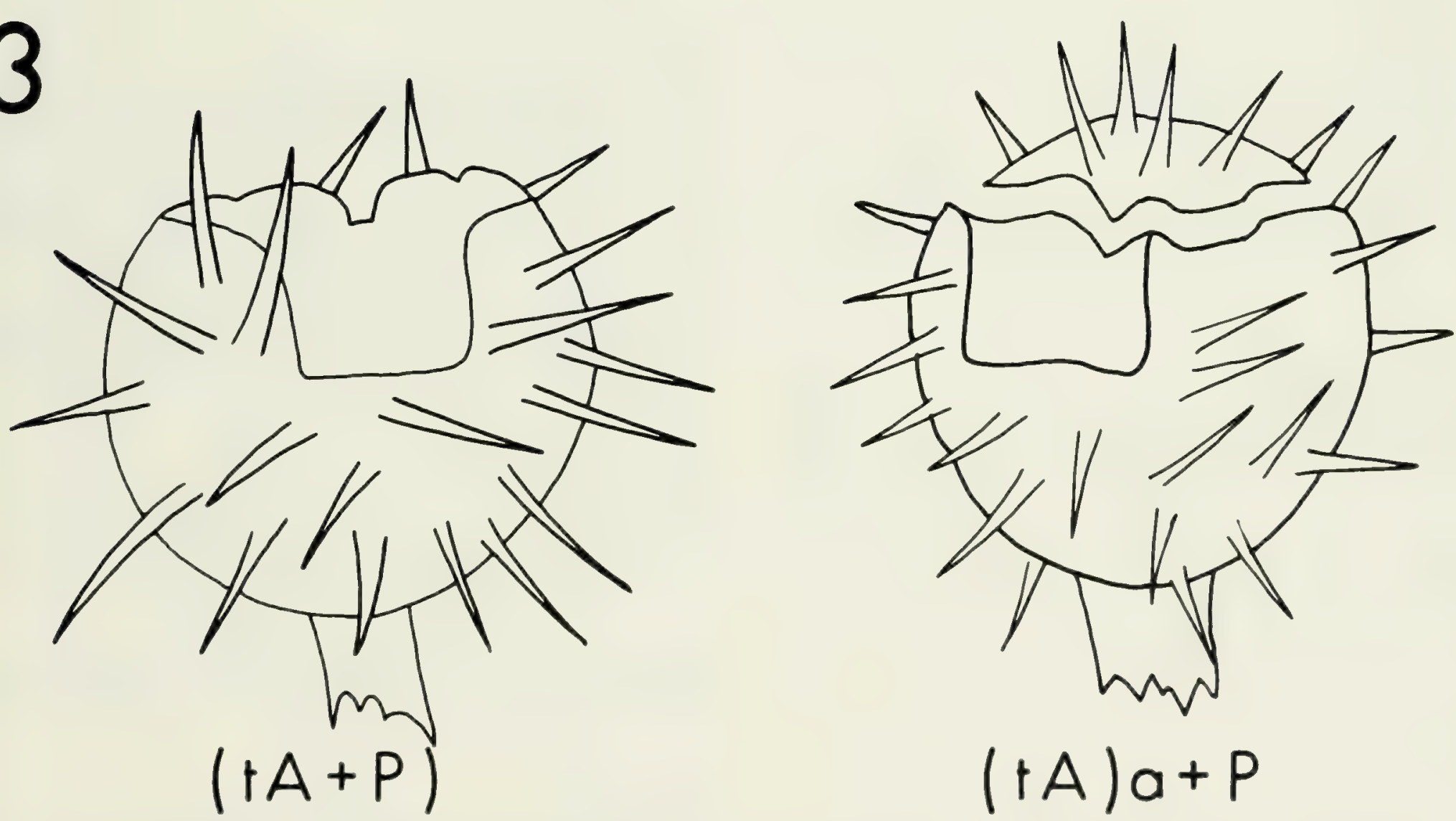

TEXT-FIG. 10. Coronifera minor (Yu and Zhang) showing various archeopyle types. I, Free of precingular plate 3". 2, Free of apical plates, precingular plate remains attached. 3, Free of both apical and precingular plates. 4 , Free of precingular plate, apical plates remain dislodged. 
mon in Zone A of Wuluokeqiate section, rare in Zone C of Wuluokeqiate and Simuhana sections; late Cretaceous.

\section{DISCUSSION}

Among 58 specimens of this species studied here, 26 have a free precingular operculum, 17 have a free apical operculum, and 15 have a free compound operculum of $(\mathrm{tA}+\mathrm{P})$. However, all specimens are identical to Diphyes minor in other respects. Yu and Zhang (1980) did not comment on the archeopyle in their description of D. minor. Coronifera minor (Yu and Zhang, 1980) is characterized as being smaller in size than previously described species of this genus, and as having processes that are slender and acuminate, straight or slightly sinuous, and approximately uniform in length and appearance.

\section{Genus Kiokansium Stover and Evitt, 1978}

\section{Kiokansium unituberculatum (Tasch, 1964) Stover and Evitt, 1978}

Pl. 5, figs. 5-7
Kiokansium unituberculatum (Tasch, 1964:194, pl. 3, fig. 8) Stover and Evitt, 1978:167.

Kiokansium sp. A Mao and Norris, 1984, pl. 2, fig. 4

See Stover and Evitt (1978:267) for a complete synonymy of Tasch's (1964) species.

\section{DIMENSIONS}

Length 32 to $53 \mu \mathrm{m}$, width 28 to $41 \mu \mathrm{m}$.

\section{STRATIGRAPHIC RANGE}

Wuyitake Formation to Tuyiluoke Formation, Zone C; common in Wuluokeqiate section; late Cretaceous.

\section{DISCUSSION}

The original description of this species by Tasch (1964) is inadequate. However, a full and comprehensive description was given by Stover and Evitt (1978:267) when they erected the genus Kiokansium, selecting Hystrichosphaeridium unituberculatum as the type species of Kiokansium. All features of specimens assigned to $K$. unituberculatum fit their description.

\section{Family Cleistosphaeridiaceae}

\section{Genus Cleistosphaeridium Davey et al., 1966}

\section{Cleistosphaeridium radiculopsis sp. nov.}

Pl. 7, figs. 21-23

Cleistosphaeridium sp. A, Mao and Norris, 1984, pl. 2, fig. 3

\section{DERIVATION OF NAME}

From the Latin radicula, a little root, in reference to the slender and branched processess that characterize this species.

\section{HOLOTYPE}

WG-31; $A_{1} ; 39.8 / 102.4$. Wuyitake Formation, Wuluokeqiate section (upper Cretaceous).

\section{PARATYPE}

WG-31; $A_{1} ; 37.5 / 109.1$. For other details see holotype.

\section{DIAGNOSIS}

Cysts skolochorate. Body spherical to oval, bearing numerous slender, sinuous nontabular processes; processes typically branched distally. No indications of tabulation other than at apical archeopyle, type (tA); operculum typically free.

\section{DESCRIPTION}

Processes relatively long ( 8 to $13 \mu \mathrm{m}$ ), narrow (less than $0.5 \mu \mathrm{m}$ across in the middle of the processes), sinuous, expanded proximally a short distance from base, slightly tapering, hairlike distally. Length of processes varies, longest being twice as long as the shortest. Processes sometimes unbranched but typically branched into two to three smaller ones at middle or one third distal part of processes, resembling fibrous roots. Autophragm thin, not absorbing stain readily. Apical archeopyle suture angular, delimiting precingular plates.

\section{DIMENSIONS}

Width 29 to $48 \mu \mathrm{m}$ (holotype $33 \mu \mathrm{m}$ ); 17 specimens measured.

\section{STRATIGRAPHIC RANGE}

Wuyitake Formation; common in Zone C of Wuluokeqiate section; late Cretaceous.

\section{DISCUSSION}

Cleistosphaeridium radiculopsis is distinguished from some similar species of Cleistosphaeridium by its unique processes. C. (?) aciculare (Davey, 1969) also has numerous acuminate and slightly flexuous processes, but these, however, are simple rather than branched, as are those of C. ehrenbergi (Deflandre, 1947), C. polyacanthum (Gitmez, 1970), and C. polytrichum (Valensi, 1947). 


\section{Family Florentiniaceae}

Genus Florentinia Davey and Verdier, 1973

Florentinia laciniata Davey and Verdier, 1973

Florentinia laciniata subsp. propria subsp. nov.

Pl. 8, figs. 2-5; Text-Fig. 11

\section{DERIVATION OF NAME}

From the Latin proprius, characteristic, in reference to the fact that the features of this species are typical for Florentinia.

\section{HOLOTYPE}

QF-86; $A_{5} ; 56.4 / 101.8$. Wulagen Formation, Qimugen section (upper Eocene).

\section{PARATYPE}

WG-63; $A_{1} ; 36.4 / 100.0$. Wulagen Formation, Wuluokeqiate section (upper Eocene).

\section{DIAGNOSIS}

Cyst skolochorate, small in size (less than $45 \mu \mathrm{m}$ ). Central body subspherical to ellipsoidal, bearing two kinds of intratabular processes: large cylindrical ones short and broad, slightly fibrous, restricted to precingular, postcingular, and antapical zones (antapical one being longest); and slender processes located in cingular and sulcal zones. Archeopyle combination of apical and precingular, type (tA + P); operculum free.

\section{DESCRIPTION}

Periphragm smooth to finely granulate and thin, forming two types of processes. Apical process composed of one or two tubules, judging from missing small apical plates. Precingular and postcingular processes almost uniformly shaped, expanded proximally, reduced in the middle, but slightly flared distally with an entire or denticulate margin; varying little in length (10 to $15 \mu \mathrm{m}$ ) and width ( 5 to $10 \mu \mathrm{m}$ ), generally short and broad, longest being less than radius of body. Antapical process longest among large processes, up to $16 \mu \mathrm{m}$ in length. Cingular and sulcal processes slender, about same length as large processes but much narrower, only 0.5 to $1.5 \mu \mathrm{m}$ in width; simple or branched, distally acuminate or capitate. Reflected tabulation possibly ?1-2', 6", ?C, 5"', $1^{\prime \prime \prime \prime}$ (Text-Fig. 11). Apical operculum free, always absent.

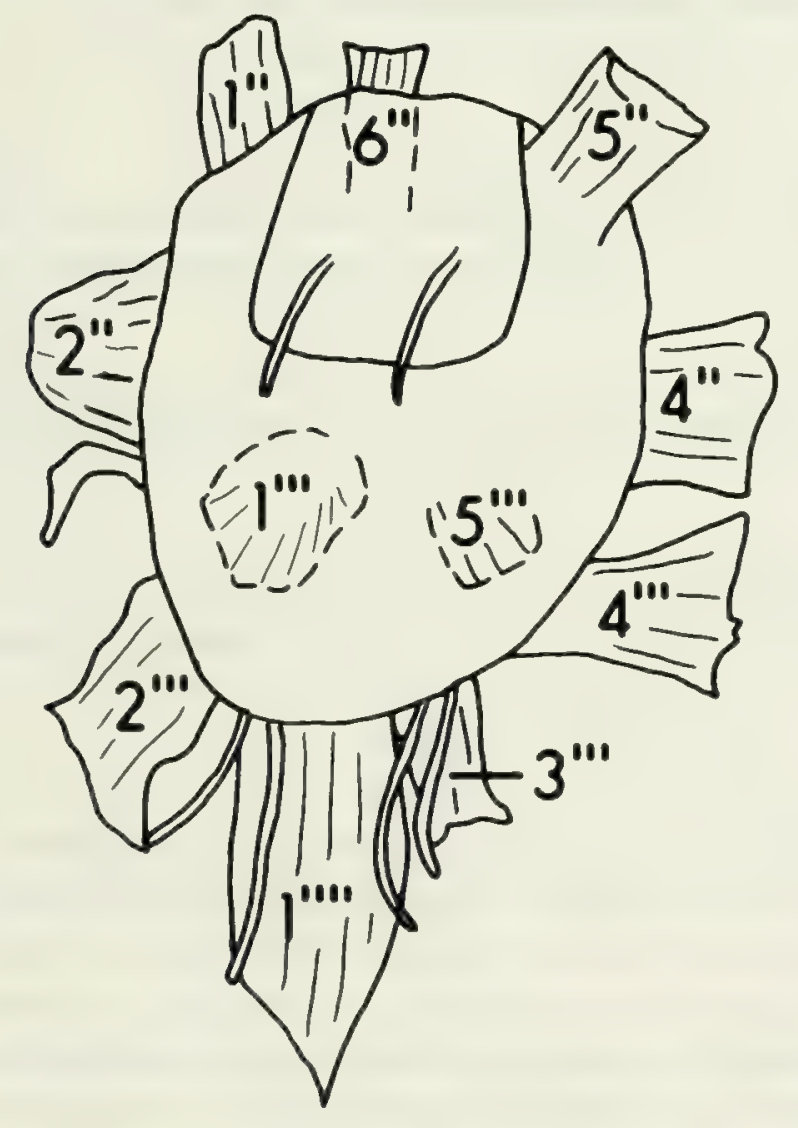

1
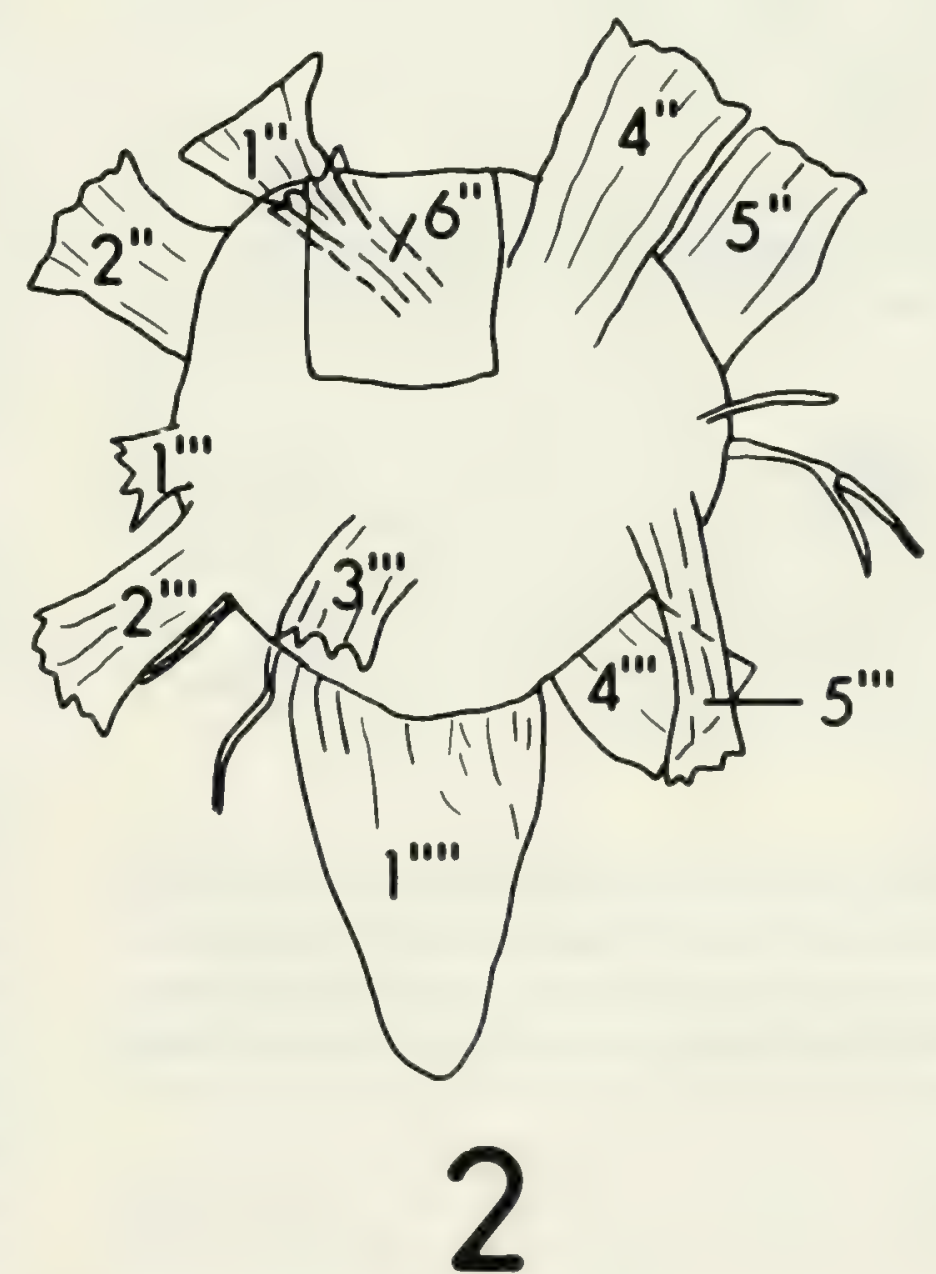

TEXT-FIG. 11. Florentinia laciniata subsp. propria subsp. nov., holotype (1, QF-86; As; 56.4/101.8) and paratype $\left(2\right.$, WG $\left.-63 ; A_{1} ; 36.4 / 100.0\right)$ from the Wulagen Formation, dorsal view, showing the distribution of the processes. 


\section{DIMENSIONS}

Length of body 25 to $44 \mu \mathrm{m}$ (holotype $44 \mu \mathrm{m}$ ), width of body 25 to $40 \mu \mathrm{m}$ (holotype $34 \mu \mathrm{m}$ ), process length 10 to $15 \mu \mathrm{m} ; 15$ specimens measured.

\section{STRATIGRAPHIC RANGE}

Wulagen Formation to Bashibulake Formation; common in Zone $\mathrm{E}$ and rare in Zone $\mathrm{F}$ of both Wuluokeqiate and Qimugen sections; late Eocene to early Oligocene.

\section{DISCUSSION}

The present subspecies is similar to Florentinia laciniata, the type species of this genus, in general characters except for a few details. The type species bears large processes of variable shape, which divide medially to give two or more tubules or which comprise a number of tubules distally; its central body diameter is 36 to $44 \mu \mathrm{m}$, and the process length is 15 to $30 \mu \mathrm{m}$. The present subspecies, however, bears almost uniformly shaped large processes, which are short and broad with entire or slightly denticulate margins distally; its central body diameter is 25 to $40 \mu \mathrm{m}$, and the process length is 10 to $15 \mu \mathrm{m}$.

\section{Genus Batiacasphaera Drugg, 1970b}

\section{Batiacasphaera hystrieosa sp. nov.} Pl. 8, figs. 17-20

\section{DERIVATION OF NAME}

From the Greek hystrieosus, thorny, with reference to the thorny ornament of the autophragm.

\section{HOLOTYPE}

WG-63; $A_{1} ; 37.3 / 109.6$. Wulagen Formation, Wuluokeqiate section (upper Eocene).

\section{PARATYPE}

WG-63; $A_{2} ; 35.0 / 107.2$. For other details see holotype.

\section{DIAGNOSIS}

Cyst proximate, subspherical to oval. Autophragm thin, granulate-microreticulate, ornamented with sparsely distributed spines. Archeopyle apical, type (tA); operculum free. Accessory archeopyle sutures indicating six precingular plates.

\section{DESCRIPTION}

Autophragm thin (about 0.5 to $1 \mu \mathrm{m}$ thick), densely covered by coarse granules often fused, forming an irregular microreticulum with relatively small lumina and broad muri. A number of adjacent granules also fused proximally, forming typically broadly based thornlike spines, usually about $2 \mu \mathrm{m}$ high, 2 to $3 \mu \mathrm{m}$ wide at their bases, and spaced 4 to $10 \mu \mathrm{m}$ apart. Cyst ouline modified by scattered larger spines, whereas anterior outline of precingular plate is delicately spinose between larger spines. Delicate spines probably represent muri of microreticulum.

\section{DIMENSIONS}

Width 45 to $85 \mu \mathrm{m}$ (holotype $58 \mu \mathrm{m}$ ); 15 specimens measured.

\section{STRATIGRAPHIC RANGE}

Wulagen Formation; common in Zone E of Wuluokeqiate section, rare in Zone E of Qimugen section; late Eocene.

\section{DISCUSSION}

Batiacasphaera hystrieosa differs from other species of this genus in having a distinctive granulate-microreticulate autophragm ornamented with sparsely distributed spines.

\section{Genus Sentusidinium Sarjeant and Stover, 1978}

\section{Sentusidinium stipulatum sp. nov.}

Pl. 8, figs. 21,22

\section{DERIVATION OF NAME}

From the Latin stipulae, stubble, with reference to the stubbly ornament of the cyst of this species.

\section{HOLOTYPE}

QF-82; $\mathrm{A}_{5} ; 43.7 / 100.8$. Wulagen Formation, Qimugen section (upper Eocene).

\section{PARATYPE}

QF-82; $A_{1} ; 37.7 / 93.7$. For other details see holotype.

\section{DIAGNOSIS}

Cyst proximate to proximochorate, subspherical to transversely ellipsoidal. Apex rounded or slightly protruding; antapex typically rounded. Autophragm characterized by ornament comprising a mixture of low to medium elements: granules, short spines, and short and fine processes on individual specimens. Archeopyle apical, type (tA). Archeopyle suture zigzag, indicating six precingular plates; operculum free or dislodged.

\section{DESCRIPTION}

Autophragm covered by nontabular low- to mediumrelief granules, spines, and pointed processes. Granules 
fine to coarse, evenly distributed on surface. Spines short and pointed, evenly or unevenly located, their proximal bases wider than their heights. Processes short and fine, usually 1 to $4 \mu \mathrm{m}$ long, rarely $10 \mu \mathrm{m}$ or more, sparsely and unevenly distributed, normally delicate and flexible, tending to lie down on surface. Process tips usually simple and blunt, seldom expanded, bifurcate or trifurcate distally.

\section{DIMENSIONS}

Width of cysts 49 to $82 \mu \mathrm{m} ; 20$ specimens measured.

\section{STRATIGRAPHIC RANGE}

Wulagen Formation to Bashibulake Formation, Zones E to $\mathrm{F}$; common in Zone $\mathrm{E}$ of Qimugen section, rare in Zone $\mathrm{F}$ of Qimugen section and in Zones $\mathrm{E}$ and $\mathrm{F}$ of Wuluokeqiate section; late Eocene to early Oligocene.

\section{DISCUSSION}

Sentusidinium stipulatum is distinguished from other species of Sentusidinium by its spherical to transversely ellipsoidal shape and its possession of more than two kinds of ornaments on individual specimens.

Family Deflandreaceae

\section{Subfamily Deflandreoideae Bujak and Davies, 1983}

\section{Genus Alterbidinium Lentin and Williams, 1985}

\section{Alterbidinium emulatum sp. nov.}

Pl. 9, figs. 1,2; Text-Fig. 12

Alterbia sp. A, Mao and Norris, 1984, pl. 1, fig. 22

\section{DERIVATION OF NAME}

From the Latin emulatus, imitating, with reference to the fact that the endoblast of this species parallels approximately the shape of periblast (see Text-Fig. 12).

\section{HOLOTYPE}

WG-18; $A_{2} ; 40.5 / 98.4$. Kukebai Formation, Wuluokeqiate section (upper Cretaceous).

\section{PARATYPE}

WG-18; $\mathrm{A}_{2} ; 42.0 / 99.3$. For other details see holotype.

\section{DIAGNOSIS}

Cyst proximate, circumcavate, elongated pentagonal with straight or convex sides. Both apical and left antapical horns short with broad bases. Endoblast subspherical to oval, relatively large, close to periphragm laterally, resulting typically in two narrow ambital pericoels. Archeopyle intercalary, type (I), attenuated hexa 2a. Transverse archeopyle index (AI) 0.35 to 0.47 .

\section{DESCRIPTION}

Cyst laterally assymetrical, ambitus biconical. Apical horn short, bluntly pointed, formed by tapering of two sides of epitract; a small circular thickening, about 2 to 3 $\mu$ m diameter, usually at top. Left antapical horn pointed with very broad base; right one either poorly developed or, more of ten, undeveloped. Shape of endoblast approximately paralleling that of periblast (see Text-Fig. 12); sometimes endoblast protruding to base of apical and left antapical horns. Periphragm thin and granulate, endophragm smooth. Cingulum usually present, 4 to 6 $\mu \mathrm{m}$ wide, slightly levorotatory, delineated by wavy folds or low denticulate ridges. Sulcus restricted to hypotract. Archeopyle on periphragm attenuated hexa, with hexagonal $2 \mathrm{a}$, relatively longer anterior lateral sides $\left(\mathrm{H}_{2}\right.$ and $\mathrm{H}_{6}$ ), and reduced posterior lateral sides $\left(\mathrm{H}_{3}\right.$ and $\left.\mathrm{H}_{5}\right)$; the anterior margin $\left(\mathrm{H}_{1}\right)$ much shorter than posterior margin $\left(\mathrm{H}_{4}\right)$, giving hexagonal archeopyle a superficially triangular shape. Archeopyle on endophragm not clearly discernible.

\section{DIMENSIONS}

Overall: length 61 to $80 \mu \mathrm{m}$ (holotype $75 \mu \mathrm{m}$ ), width 40 to $50 \mu \mathrm{m}$ (holotype $46 \mu \mathrm{m}$ ); endoblast: length 36 to $60 \mu \mathrm{m}$ (holotype $50 \mu \mathrm{m}$ ), width 30 to $45 \mu \mathrm{m}$ (holotype $42 \mu \mathrm{m}$ ); 15 specimens measured.

\section{STRATIGRAPHIC RANGE}

Kukebai Formation to Yigeziya Formation, Zones B to $\mathrm{C}$; abundant in Zone B of Wuluokeqiate section, rare in Zone C of Wuluokeqiate and Simuhana sections; late Cretaceous.

\section{DISCUSSION}

Alterbidinium emulatum resembles $A$. acutulum and Isabelidinium acuminatum. It differs from $A$. acutulum in having a cyst that is plump, with two sides of the epitract straight or convex, and apical and left antapical horns that are much shorter. I. acuminatum differs from A. emulatum in possessing (1) an endoblast of smaller size, located more centrally in the cyst, and a circular ambitus slightly pointed towards the apex and (2) a relatively wide pericoel between the endophragm and periphragm. A. emulatum also shows some similarity to Deflandrea psilata, but the latter is smaller (48 to $50 \mu \mathrm{m}$ ) 


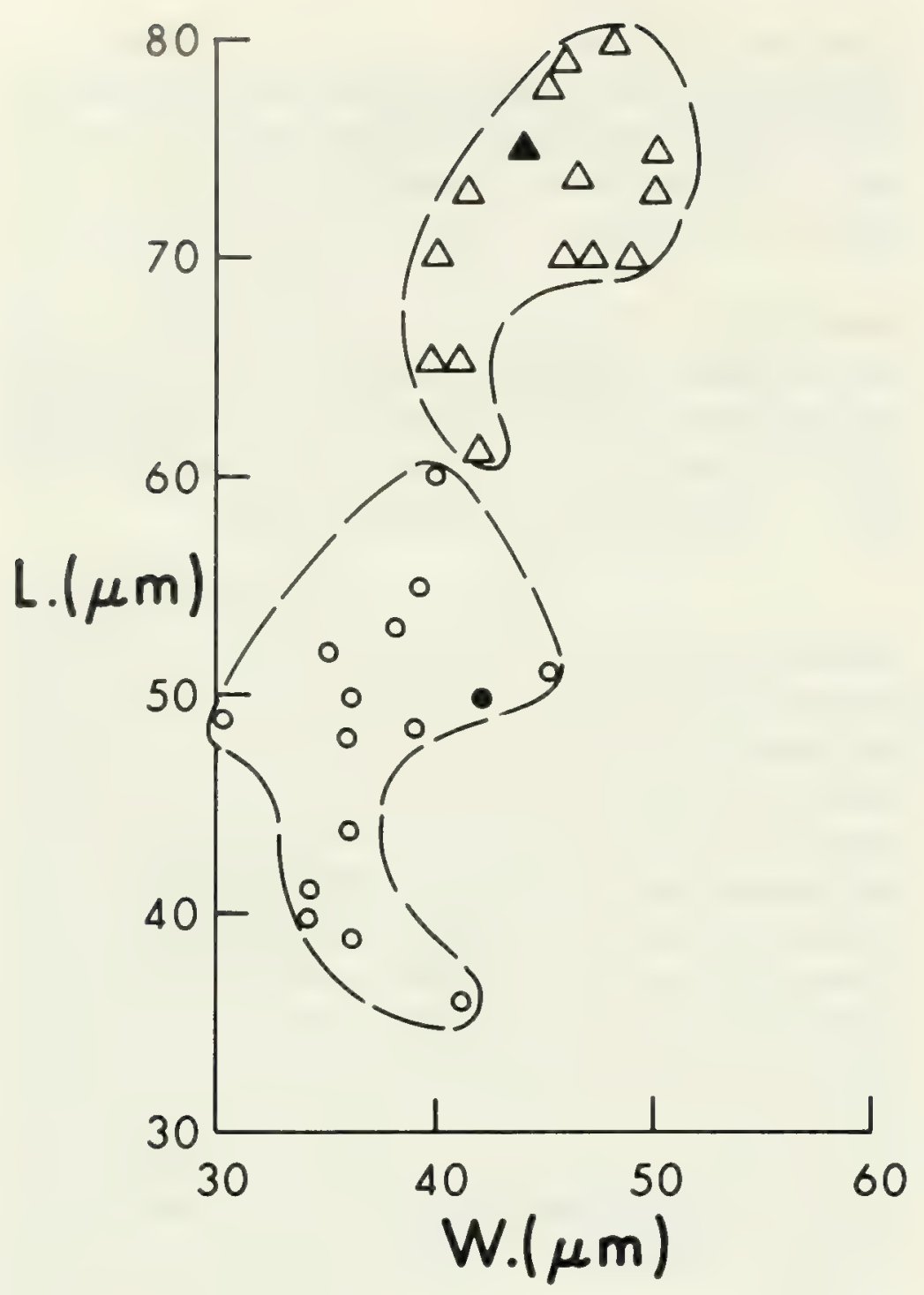

$\triangle$ Periblast

- Endoblast

TEXT.FIG. 12 . Dimensions ( $L$, length; $W$., width) of periblasts and endoblasts of Alterbidinium emulatum sp. nov. Holotype is indicated by solid circle and triangle.

and has two weakly developed antapical horns; the former typically has only the left antapical horn developed. $A$. emulatum is also comparable to $A$. montanaense, but the latter species is much smaller (only 18.75 to $36.25 \mu \mathrm{m}$ long, 8.75 to $25 \mu \mathrm{m}$ wide), has two sides of the epitract concave rather than straight or convex, and has a long and prominent apical horn.

\section{Genus Ceratiopsis Vozzhennikova, 1963}

\section{Ceratiopsis speciosa (Alberti, 1959) Lentin and Williams, 1977}

Ceratiopsis speciosa subsp. elongata subsp. nov. Pl. 9, figs. 10-12

\section{DERIVATION OF NAME}

From the Greek elongatus, elongate, with reference to the elongate cysts of this subspecies.

\section{HOLOTYPE}

QF-49; $A_{1} ; 45.7 / 104.0$. Qimugen Formation, Qimugen section (upper Paleocene).

\section{PARATYPE}

QF-51; $A_{1} ; 1$ 19.0/106.2. Qimugen Formation, Qimugen section (upper Paleocene).

\section{DIAGNOSIS}

Cyst proximate, circumbicavate. Ambitus elongate, length relatively longer than width, epitract distinctly bigger than hypotract. Apical horn long, protruding. Antapical horns two, typically equal, divergent, with broad bases and pointed distal ends. Periphragm ornamented with coarse granules, tubercules, and cones, giving rise to denticulate lineation of cyst. Endophragm smooth. Endoblast subspherical, its length greater than its width, filling in middle part of pericoel. Cingulum slightly levorotatory, shallow. Archeopyle intercalary, type (I) formed by loss of $2 \mathrm{a}$, broad hexa style.

\section{DESCRIPTION}

Epitract shaped like an equilateral triangle plus an attenuated apical horn; apical horn long, sinuous, usually 30 to $40 \mu \mathrm{m}$ long and 8 to $12 \mu \mathrm{m}$ wide at the base. Hypotract trapezoid with two divergent clawlike antapical horns wider at bases ( 24 to $36 \mu \mathrm{m}$ ), 20 to $38 \mu \mathrm{m}$ long, pointed distally. Endoblast subspherical, occupying middle part of pericoel, giving rise to 0 -to-6- $\mu$ m-wide narrow ambital pericoels and well-developed apipericoel and antapipericoels. Periphragm covered with coarse granules, irregularly shaped, sometimes faintly intratabular, and with tubercules and cones. Tubercules and cones sometimes fused proximally, forming low ridges. Cingulum marked laterally by ridges and dorsoventrally by aligned granules and tubercules.

\section{DIMENSIONS}

Length 148 to $160 \mu \mathrm{m}$ (holotype $160 \mu \mathrm{m}$ ), width 68 to 80 $\mu \mathrm{m}$ (holotype $80 \mu \mathrm{m}$ ); 20 specimens measured.

\section{STRATIGRAPHIC RANGE}

Qimugen Formation; abundant in Zone D of Qimugen section, rare in Zone D of Simuhana section; late Paleocene.

\section{DISCUSSION}

This new subspecies is closely comparable to Ceratiopsis speciosa subsp. glabra. The overall shape of the new subspecies is more elongate than that of the latter, and the periphragm is ornamented with features of low relief rather than being typically smooth. 


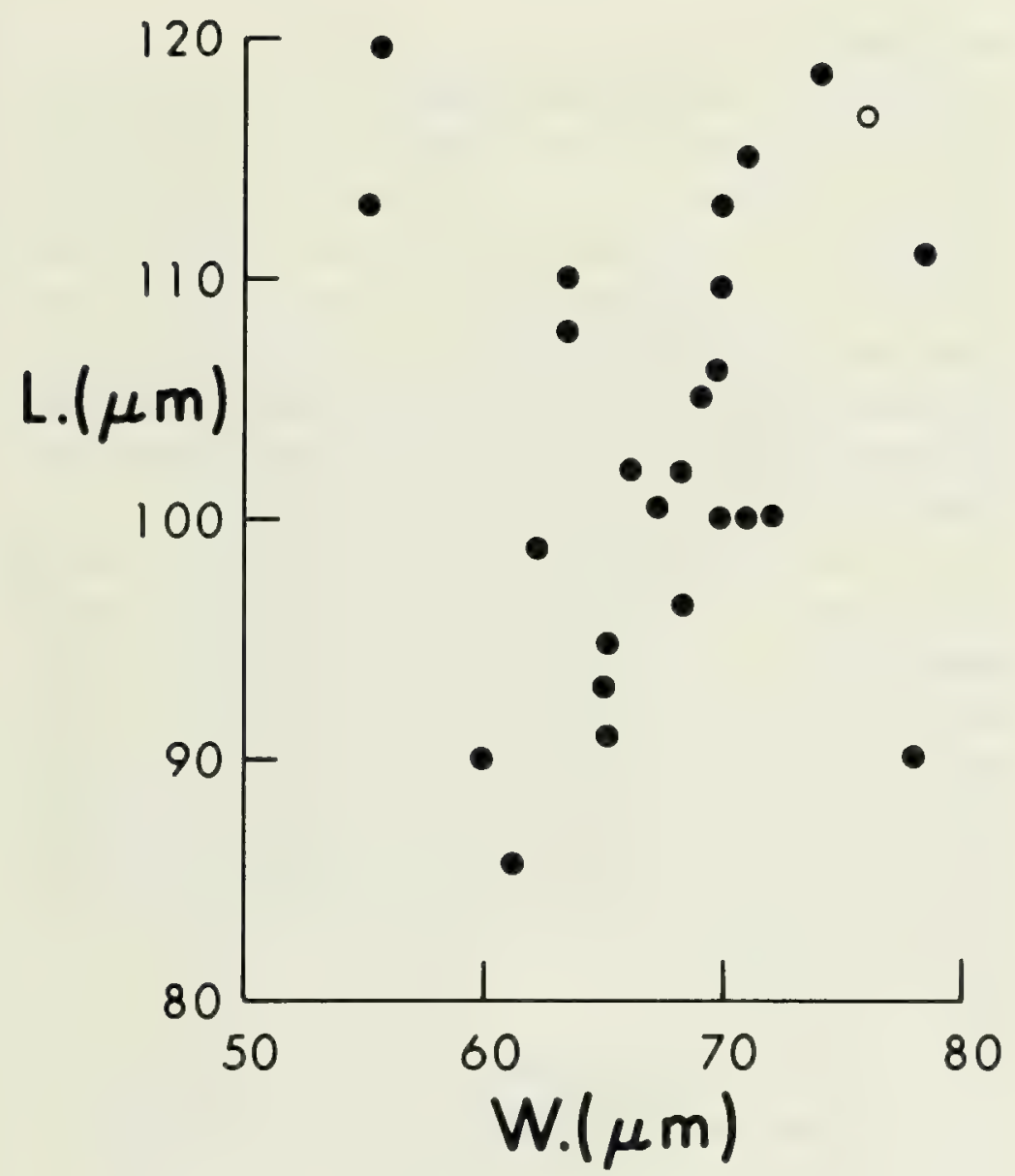

TEXT-Fig. 13. Dimensions (L., length; $W$., width) of Deflandrea intrasphaerula sp. nov. Holotype is indicated by a circle.

\section{Genus Deflandrea Eisenack, 1938}

\section{Deflandrea intrasphaerula sp. nov.}

Pl. 10, figs. 4-6; Text-Fig. 13

Deflandrea sp. A, Mao and Norris, 1984, pl. 3, fig. 9

\section{DERIVATION OF NAME}

From the Latin intra, within, and sphaera, globe, in reference to the large endoblast, which lies just inside the periphragm.

\section{HOLOTYPE}

WG-74; $\mathrm{A}_{2} ; 44.8 / 108.0$. Bashibulake Formation, Wuluokeqiate section (lower Oligocene).

\section{PARATYPE}

WG-70; $\mathrm{A}_{10} ; 41.4 / 104.4$. For other details see holotype.

\section{DIAGNOSIS}

Cyst proximate, circumbicavate, two lateral sides strongly convex. On one apical and two antapical sides, horns pointed and moderately developed. Ambital pericoel almost absent or very narrow because of relatively large and spherical endoblast filling most of pericoel. Archeopyle intercalary, type (I), broad hexa 2a; transverse AI 0.74 to 0.80 (holotype 0.75 ); operculum usually free.

\begin{abstract}
DESCRIPTION
Cyst appearing plump, owing to large spherical endoblast occupying most of pericoel. Ambital pericoel very narrow (less than $4 \mu \mathrm{m}$ wide) or completely absent. Apical horn bluntly pointed with broad base; two divergent antapical horns typically equal or slightly unequal, triangular in shape. Asymmetric appearance of two antapical horns resulting from specimens not being mounted in dorsoventral direction. Periphragm thin, smooth or finely granulate. Endophragm finely granulate to granulate. Cingulum, where present, indicated by faint low ridges. Sulcus broad, almost reaching the antapex.
\end{abstract}

\section{DIMENSIONS}

Length 85 to $120 \mu \mathrm{m}$ (holotype $117 \mu \mathrm{m}$ ), width 35 to 78 $\mu \mathrm{m}$ (holotype $76 \mu \mathrm{m}$ ); 25 specimens measured.

\section{STRATIGRAPHIC RANGE}

Bashibulake Formation, abundant in Zone F of Wuluokeqiate section; early Oligocene.

\section{DISCUSSION}

This species is characterized by a relatively large spherical endoblast that fills most of the pericoel. As a result, the cysts look plump, the ambital pericoels are very narrow (less than $4 \mu \mathrm{m}$ wide) or even absent, and the antapical pericoel is also reduced. In these features, therefore, Deflandrea intrasphaerula sp. nov. differs from $D$. phosphoritica and $D$. oebisfeldensis.

\section{Deflandrea musculopsis sp. nov.}

Pl. 10, figs. 7-10; Text-Fig. 14

Deflandrea sp. B, Mao and Norris, 1984, pl. 3, fig. 11

\section{DERIVATION OF NAME}

From the Latin musculus, a mouse, in reference to the small size of the cysts of this species.

\section{HOLOTYPE}

QF-86; $\mathrm{A}_{2} ; 52.1 / 97.1$. Wulagen Formation, Qimugen section (upper Eocene).

\section{PARATYPE}

SM-77; $\mathrm{A}_{2} ; 34.0 / 107.4$. For other details see holotype.

\section{DIAGNOSIS}

Cyst proximate, circumcavate to cornucavate, small in size (less than $70 \mu \mathrm{m}$ ). Ambitus rounded, pentagonal, with apical horn and two small antapical horns. Endoblast spherical to subspherical, relatively large, occupying major portion of pericoel. Wall thin and 
smooth. Archeopyle intercalary, type (I), broad hexa 2a; transverse AI 0.6 to 0.7 (holotype 0.63 ). Operculum free.

\section{DESCRIPTION}

Cyst small, length usually less than $60 \mu \mathrm{m}$. Apical horn blunt or rounded, usually with broad base, 6 to $11 \mu \mathrm{m}$ long, 6 to $18 \mu \mathrm{m}$ wide at base. Two antapical horns small ( 2 to $5 \mu \mathrm{m}$ long, 3 to $6 \mu \mathrm{m}$ wide at their bases), equal or slightly unequal, with left one bigger. Periphragm smooth or finely granulate; endophragm smooth, thin, with many longitudinal folds. Ambital pericoel very narrow ( 0 to $2.5 \mu \mathrm{m}$ wide) because of relatively large spherical to subspherical endoblast filling large portion of pericoel. Cingulum 4 to $6 \mu \mathrm{m}$ wide, delimited by folds or low ridges, planar or slightly levorotatory. Indications of tabulation other than archeopyle and cingulum absent. Omphalos often found near junction of cingulum and sulcus, spherical to subspherical in shape, readily stained, darker colour than adjacent wall.

\section{DIMENSIONS}

Length 45 to $67.5 \mu \mathrm{m}$ (holotype $57 \mu \mathrm{m}$ ), width 31 to 54 $\mu \mathrm{m}$ (holotype $41 \mu \mathrm{m}$ ); 45 specimens measured (see Text-Fig. 14).

\section{STRATIGRAPHIC RANGE}

Qimugen Formation to Bashibulake Formation, Zones $\mathrm{D}$ to $\mathrm{F}$; rare in Zone D of Simuhana section, abundant in Zone E of Qimugen section, rare in Zone E of Wuluokeqiate section and rare in Zone $\mathrm{F}$ of Qimugen and Wuluokeqiate sections; late Paleocene to early Oligocene.

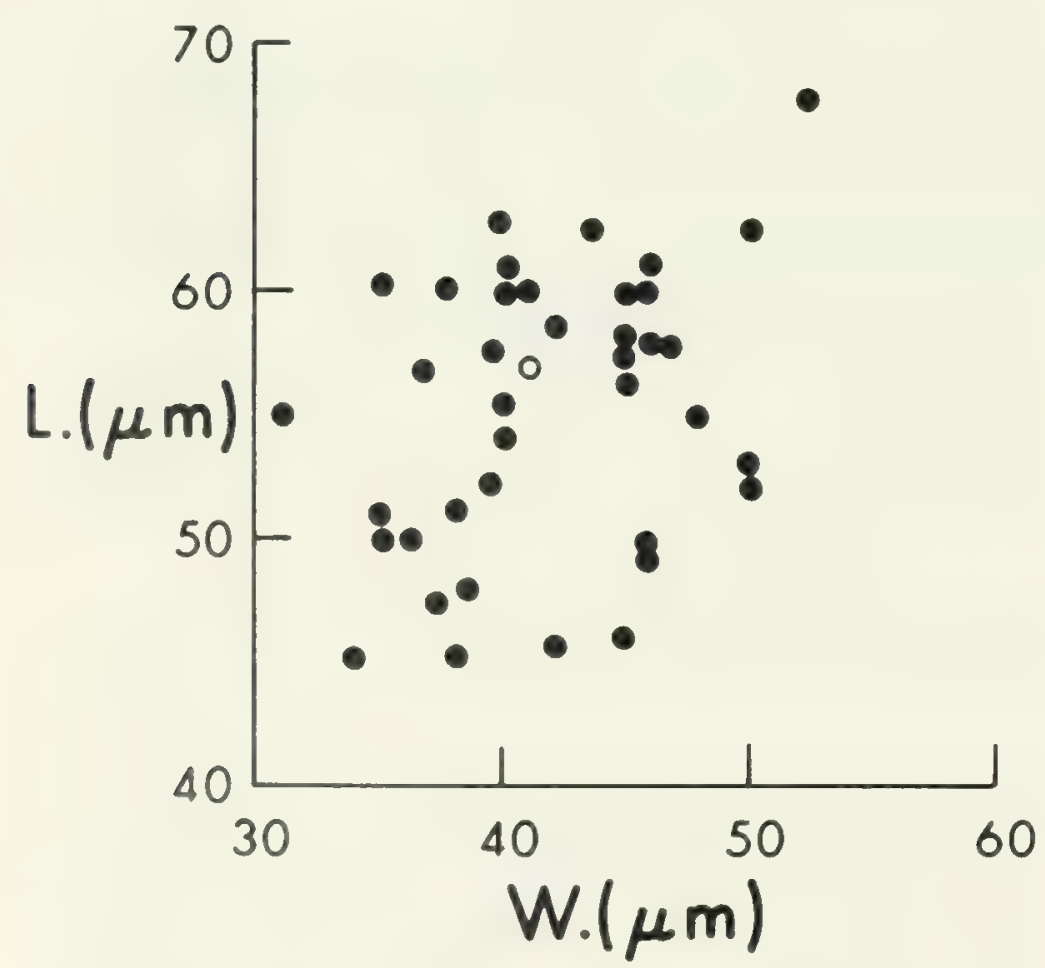

TEXT-FIG. 14. Dimensions ( $L$., length; $W$., width) of Deflandrea musculopsis sp. nov. Holotype is indicated by a circle.

\section{DISCUSSION}

On the basis of its small size (usually less than $60 \mu \mathrm{m}$ ) and its thin and almost smooth wall, this species can be distinguished from all other species of Deflandrea, with the exception of $D$. psilata, which has a circumcavate cyst with oval endoblast and broad ambital pericoel, and a standard hexa (I) archeopyle. D. musculopsis is closely comparable to Senegalinium microgranulatum and Subtilisphaera ventriosa. It differs from Senegalinium microgranulatum in the combination of the following features: (1) the wall is smooth rather than granulate; (2) the ambital pericoel is always weakly developed instead of absent; (3) the archeopyle is broad hexa style rather than standard hexa style. Subtilisphaera ventriosa has no indication of an archeopyle. D. musculopsis is also similar to Phelodinium pumilum; however, the latter species has a very thin and transparent periphragm and an intercalary archeopyle 2a typically with the antapical margin close to the cingulum.

\section{Genus Eurydinium Stover and Evitt, 1978}

Eurydinium tempestivum sp. nov.

Pl. 11, figs. 15-17; Text-Fig. 15

Isabelidinium sp. B, Mao and Norris, 1984, pl. 1, fig. 25

\section{DERIVATION OF NAME}

From the Latin tempestivus, ripe or mature, in reference to the well-rounded appearance of the cyst.

\section{HOLOTYPE}

WG-18; $A_{2} ; 47.6 / 102.3$. Kukebai Formation, Wuluokeqiate section (upper Cretaceous).

\section{PARATYPE}

WG-18; $A_{2} ; 43.0 / 94.2$. For other details see holotype.

\section{DIAGNOSIS}

Cyst proximate, circumcavate, subspherical, with strong convex sides. Apical horn small, prominent; either only left antapical horn or two antapical horns of unequal length developed; in either case, horn or horns typically small, pointed. Endoblast large, spherical, length commonly slightly greater than width and rarely equal with it. Wall thin, smooth to granulate. Cingulum expressed by folds or low ridges, not making an equatorial bulge in ambital view. Archeopyle intercalary, type (I), standard hexa 2a, transverse AI 0.41 to 0.5 (holotype $0.49 \mu \mathrm{m}$ ).

\section{DESCRIPTION}

Epitract triangular, two sides being more or less convex. Apical horn short (2.5 to $4 \mu \mathrm{m}$ high), bluntly pointed. 


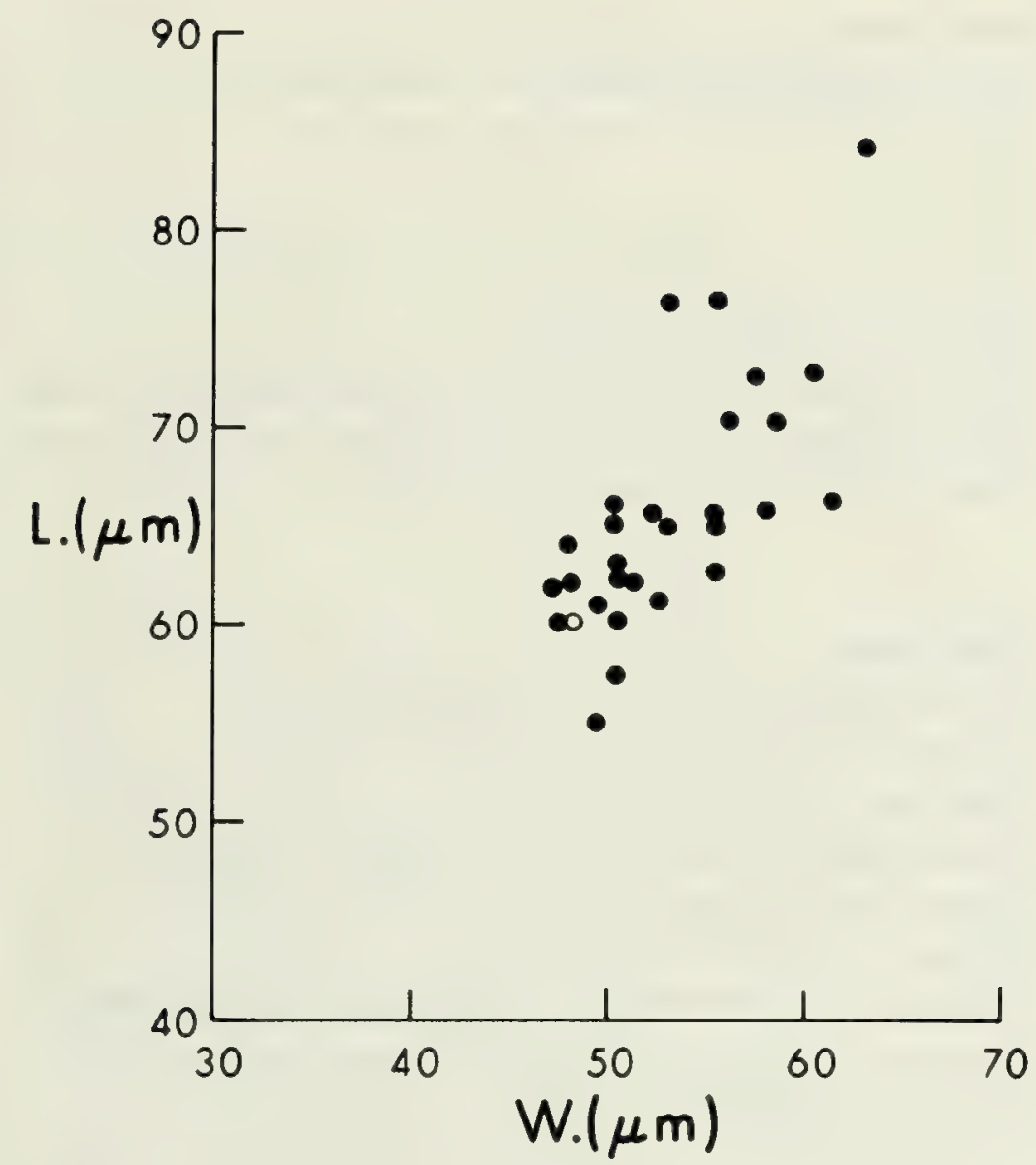

TEXT-Fig. 15. Dimensions ( $L$., length; $W$., width) of cysts of Eurydinium tempestivum sp. nov. Holotype is indicated by a circle.

Hypotract subtriangular to semicircular with one left antapical horn or trapezoid with two antapical horns, two sides typically straight or slightly convex, antapical margin straight or slightly concave. Antapical horn or horns small ( 2 to $4 \mu \mathrm{m}$ long), pointed, protruding from general outline; if two horns developed, left longer than right. Endoblast spherical to subellipsoidal, length slightly greater than width, occupying large portion of the pericoel, leaving 2-to-6- $\mu \mathrm{m}$-wide ambital and antapical pericoels. Cingulum planar or slightly levorotatory, delimited by wavy folds or low ridges, 4 to $6 \mu \mathrm{m}$ wide. Archeopyle standard hexa or superficially triangular because of lateral sides $\mathrm{H}_{2}$ and $\mathrm{H}_{6}$ being relatively longer than sides $\mathrm{H}_{3}$ and $\mathrm{H}_{5}$, and anterior margin $\mathrm{H}_{1}$ being considerably shorter than posterior margin $\mathrm{H}_{4}$. Sulcus not always discernible, restricted to hypotract.

\section{DIMENSIONS}

Overall: length 55 to $84 \mu \mathrm{m}$ (holotype $60 \mu \mathrm{m}$ ), width 46 to $62.5 \mu \mathrm{m}$ (holotype $48 \mu \mathrm{m}$ ); endoblast: length 40 to $60 \mu \mathrm{m}$ (holotype $40 \mu \mathrm{m}$ ), width 38 to $53 \mu \mathrm{m}$ (holotype $38 \mu \mathrm{m}$ ); 30 specimens measured (see Text-Fig. 15).

\section{STRATIGRAPHIC RANGE}

Kukebai Formation; abundant in Zone B of Wuluokeqiate section; Turonian to Coniacian or to Santonian.

\section{DISCUSSION}

Eurydinium tempestivum is characterized by its subspherical pericyst with a large spherical to broadly ellipsoidal endoblast, one short apical horn, and one or two small pointed antapical horns. It is closely comparable to $E$. ingramii, which has an elongate cyst with two sides less convex than the cyst of this species. Its ratio of length to width is 0.72 to 0.74 , whereas that of $E$. tempestivum is 0.75 to 0.89 . In addition, the antapical horn or horns of $E$. ingramii, when developed, are always distinct and pointed, no matter how small. E. tempestivum resembles Subtilisphaera foliacea but is readily differentiated from that species by its possession of a distinct intercalary archeopyle and a prominent apical horn. E. tempestivum is also similar to Deflandrea tribulosa, but the latter Tertiary species has two equally developed antapical horns.

\section{Genus Trithyrodinium Drugg, 1967, emend. Lentin and Williams, 1976}

\section{Trithyrodinium sabulum sp. nov.}

Pl. 12, figs. 1-4; Text-Figs. 16,17

Trithyrodinium sp. A, Mao and Norris, 1984, pl. 1, fig.1

\section{DERIVATION OF NAME}

From the Latin sabulum, sand, with reference to the granulate ornament of the endophragm in this species.

\section{HOLOTYPE}

WG-13; $B_{2} ; 39.1 / 107.2$. Kukebai Formation, Wuluokeqiate section (upper Cretaceous).

\section{PARATYPE}

WG-13; $\mathrm{A}_{1} ; 29.8 / 105.8$. For other details see holotype.

\section{DIAGNOSIS}

Cyst proximate, cornucavate, subspherical to elliptical with an apical horn, and with or without two poorly developed, unequal antapical horns appearing as angular bulges, the left one usually being longer. Wall layers thin (less than $1 \mu \mathrm{m}$ ), folded. Periphragm transparent and delicate, smooth or with scattered granules; endophragm granulate, thicker than periphragm. Archeopyle intercalary, more clearly indicated in endoblast than in periblast, type $3 \mathrm{I} / 3 \mathrm{I}$. Operculum compound, typically dislodged or 1a and $3 \mathrm{a}$ detached and $2 \mathrm{a}$ attached posteriorly.

\section{DESCRIPTION}

Cyst transversely to longitudinally broad, elliptical in ambital view. Apical horn present, small, bluntly pointed 
or nipplelike, 4 to $7 \mu \mathrm{m}$ long, formed usually by periphragm. Antapex rounded or stretched out to two angular bulges. Periphragm very thin, easily folded, transparent, lightly coloured or not easily stained. Periphragm sometimes lost, leaving endoblast free. Endophragm thin, thicker than periphragm, typically densely granulate; diameter of granules varying, commonly less than $1 \mu \mathrm{m}$. Intercalary 3I archeopyle compound and linteloid. When the archeopyle not fully developed and the periphragm not removed, plates 1 to 3a recognizable by slightly open sutures; in that case (18 of 38 specimens observed) the posterior suture of $2 a$ absent (Text-Fig. 16). When periphragm completely lost (18 of 38 specimens), plates la and $3 \mathrm{a}$ detached, plate $2 \mathrm{a}$ remaining attached along its posterior margin (Text-Fig. 17); rarely ( 2 of 38 specimens observed), three opercular pieces totally free. Therefore, plate 2a may have stronger connection with endoblast than plates $1 \mathrm{a}$ and $3 \mathrm{a}$, because it is removed after the other two. Plate $2 \mathrm{a}$ standard hexa, plates 1a and $3 \mathrm{a}$ pentagonal in shape. Indications of tabulation, other than archeopyle, absent.

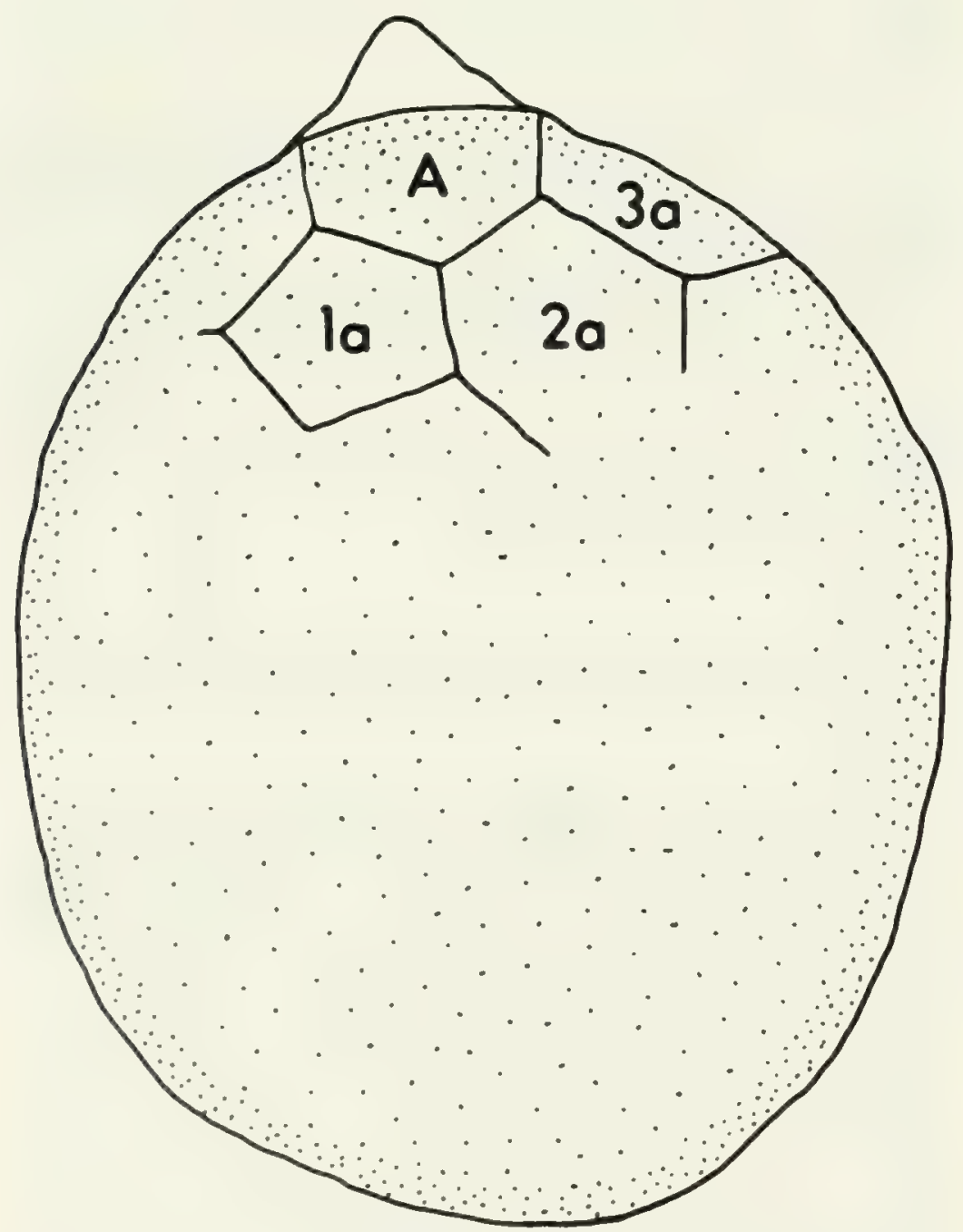

TEXT-FIG. 16. Trithyrodinium sabulum sp. nov., a specimen showing 3 I attached, WG-13; $\mathrm{B}_{2} ; 39.1 / 107.2$.

\section{DIMENSIONS}

Length 45 to $65 \mu \mathrm{m}$ (holotype $54 \mu \mathrm{m}$ ), width 35 to $53 \mu \mathrm{m}$ (holotype $44 \mu \mathrm{m}$ ); 38 specimens measured.

\section{STRATIGRAPHIC RANGE}

Kukebai Formation to Yigeziya Formation, Zones A to $\mathrm{C}$; abundant in Zones $\mathrm{A}$ and $\mathrm{B}$ of Wuluokeqiate section, rare in Zone $\mathrm{C}$ of both Wuluokeqiate and Simuhana sections; late Cretaceous.

\section{DISCUSSION}

This species differs from Trithyrodinium evittii in that (1) its three opercular plates do not function as a unit, (2) the cingulum is typically not indicated, and (3) the endophragm is granulate rather than psilate. It differs from $T$. suspectum (Manum and Cookson, 1964) in having thinner wall layers; the wall layers of $T$. suspectum are composed of rod-shaped elements of unequal length, such structures being completely absent in $T$. sabulum .

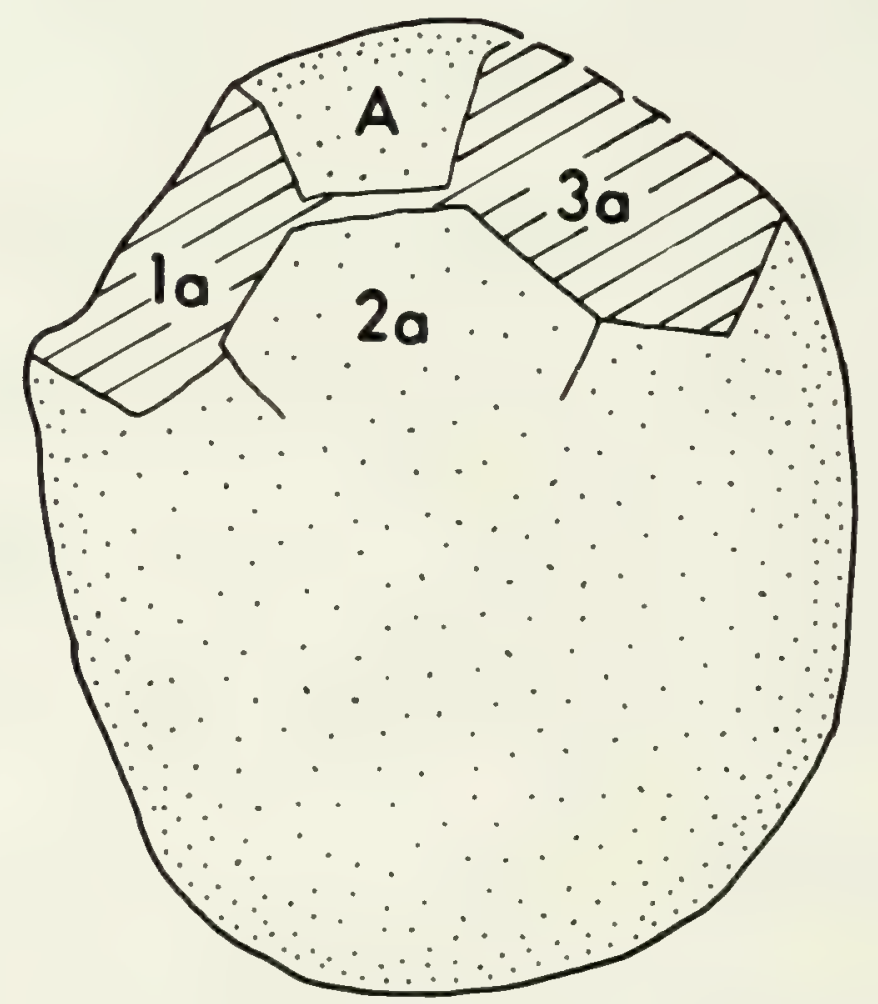

TEXT-FIG. 17. Trithyrodinium sabulum sp. nov., a specimen showing $2 \mathrm{a}$ attached, $1 \mathrm{a}$ and $3 \mathrm{a}$ detached, WG-13; $\mathrm{A}_{1}$; 29.8/105.8. 


\section{Genus Palaeohystrichophora Deflandre, 1935}

\section{Palaeohystrichophora granulata sp. nov.}

Pl. 12, figs. $9-12$

\section{DERIVATION OF NAME}

From the Latin grana, granule, in reference to the granulate ornamentation of this species.

\section{HOLOTYPE}

WG-13; $\mathrm{B}_{1} ; 37.9 / 104.5$. Kukebai Formation, Wuluokeqiate section (upper Cretaceous).

\section{PARATYPE}

WG-13; $\mathrm{B}_{1} ; 47.5 / 104.0$. For other details see holotype.

\section{DIAGNOSIS}

Cyst proximate, typically bicavate, with distinct apical horn and two unequally or weakly developed antapical horns. Wall thin; periphragm finely granulate, bearing a few sporadically distributed hairlike processes; endophragm smooth to sparsely granulate. Endoblast subspherical to rhombic, width equal to or typically slightly greater than length. Cingulum always present, bounded by folds or low ridges. Archeopyle usually indiscernible; if indicated, combination of intercalary and precingular, type (3I3P). Operculum attached posteriorly like a flap.

\section{DESCRIPTION}

Cyst compressed peridinioid, rounded pentagonal. Tapering apical horn triangular in shape, 7 to $12.5 \mu \mathrm{m}$ high, base broader than height. Two antapical horns either weakly and equally developed as a pair of bulges ( 3 to 4 $\mu \mathrm{m}$ high) or unequally developed, left one being high (5 to $10 \mu \mathrm{m})$ and more pointed than right. Two-layered wall less than $1 \mu \mathrm{m}$ thick; periphragm transparent, not ac cepting stain readily, finely granulate, typically bearing several (usually less than 10) sporadic hairlike spines. Subspherical endoblast protruding more into epitract than hypotract, with breadth (44 to $54 \mu \mathrm{m}$ ) slightly greater than length (40 to $50 \mu \mathrm{m})$, occupying most of pericoel, leaving small apical and antapical pericoels and very narrow ( 1 to $3 \mu \mathrm{m}$ ) ambital pericoel. Cingulum well defined, planar, 4 to $6 \mu \mathrm{m}$ wide. Most of observed specimens showing no indication of archeopyle. Rarely, simple flaplike operculum remaining attached posteriorly, indicating archeopyle probably composed of three intercalary and three precingular plates ( 1 to $3 a, 3$ to $5^{\prime \prime}$ ).

\section{DIMENSIONS}

Length 58 to $70 \mu \mathrm{m}$ (holotype $64 \mu \mathrm{m}$ ), width 44 to $56 \mu \mathrm{m}$ (holotype $55 \mu \mathrm{m}$ ); 12 specimens measured.

\section{STRATIGRAPHIC RANGE}

Kukebai Formation to Yigeziya Formation, Zones A to $\mathrm{C}$; common in Zone $\mathrm{A}$ of Wuluokeqiate section, rare in Zones B and C of Wuluokeqiate section and Zone C of Simuhana section; late Cretaceous.

\section{DISCUSSION}

The present new species shows similarity to Palaeohystrichophora infusorioides but differs in having granules and only a few sporadic hairlike processes on its periphragm, whereas the latter bears numerous and even!y distributed hairlike processes. $P$. granulata differs from Talimu dinium scissurum sp. nov. in possessing the following combination of features: (1) the periphragm usually bears a few sporadic hairlike processes; (2) the width of the endoblast is equal to or, typically, slightly greater than the length of it; (3) the archeopyle is a combination of (3I3P) rather than a combination of $(\mathrm{A} 3 \mathrm{I} 2 \mathrm{P})$.

\section{Subfamily Incertae}

\section{Genus Talimudinium gen. nov.}

\section{DERIVATION OF NAME}

Named for the Tarim (Talimu) Basin, Xinjiang Province, China.

\section{TYPE SPECIES}

Talimudinium scissurum sp. nov., late Cretaceous.

\section{DIAGNOSIS}

Cyst proximate, typically bicavate to cornucavate, peridinioid, with an apical and two antapical horns, the last two being well to weakly developed and unequal in size, with the left one usually longer than the right. Periphragm thin, smooth or sparsely granulate; endophragm also thin, smooth or with scattered granules. Cingulum distinct, delineated by folds or ridges of low to medium height. Tabulation indistinct, weakly indicated by imperfect low sutural ridges; when discernible, peridiniacean, 4', 3a, 7", 6-7C, 5"', 2"'”. Archeopyle transapical, type (tA3I2P). The archeopyle suture dividing epitract into unequal parts, the large part being composed of apical, intercalary, and two $\left(1 ", 2^{\prime \prime}\right)$ precingular plates. 


\section{DISCUSSION}

Talimudinium is morphologically similar in some respects to Palaeoperidinium Deflandre, 1935; Subtilisphaera Jain and Millepied, 1973; and Palaeohystrichophora Deflandre, 1935; but differs in having a transapical archeopyle, type (A3I2P). Additionally, its lack of hairlike processes further distinguishes it from Palaeohystrichophora. Ovoidinium Davey, 1970, differs from Talimudinium in having an archeopyle interpreted as type (tAtI).
Talimudinium scissurum sp. nov.

Pl. 15, figs. 8-13; Text-Fig. 18

\section{DERIVATION OF NAME}

From the Latin scissura, a splitting, with reference to the type of archeopyle suture found in this species.

\section{HOLOTYPE}

SM-60; $\mathrm{A}_{4} ; 40.8 / 102.5$. Yigeziya Formation, Simuhana section (upper Cretaceous).
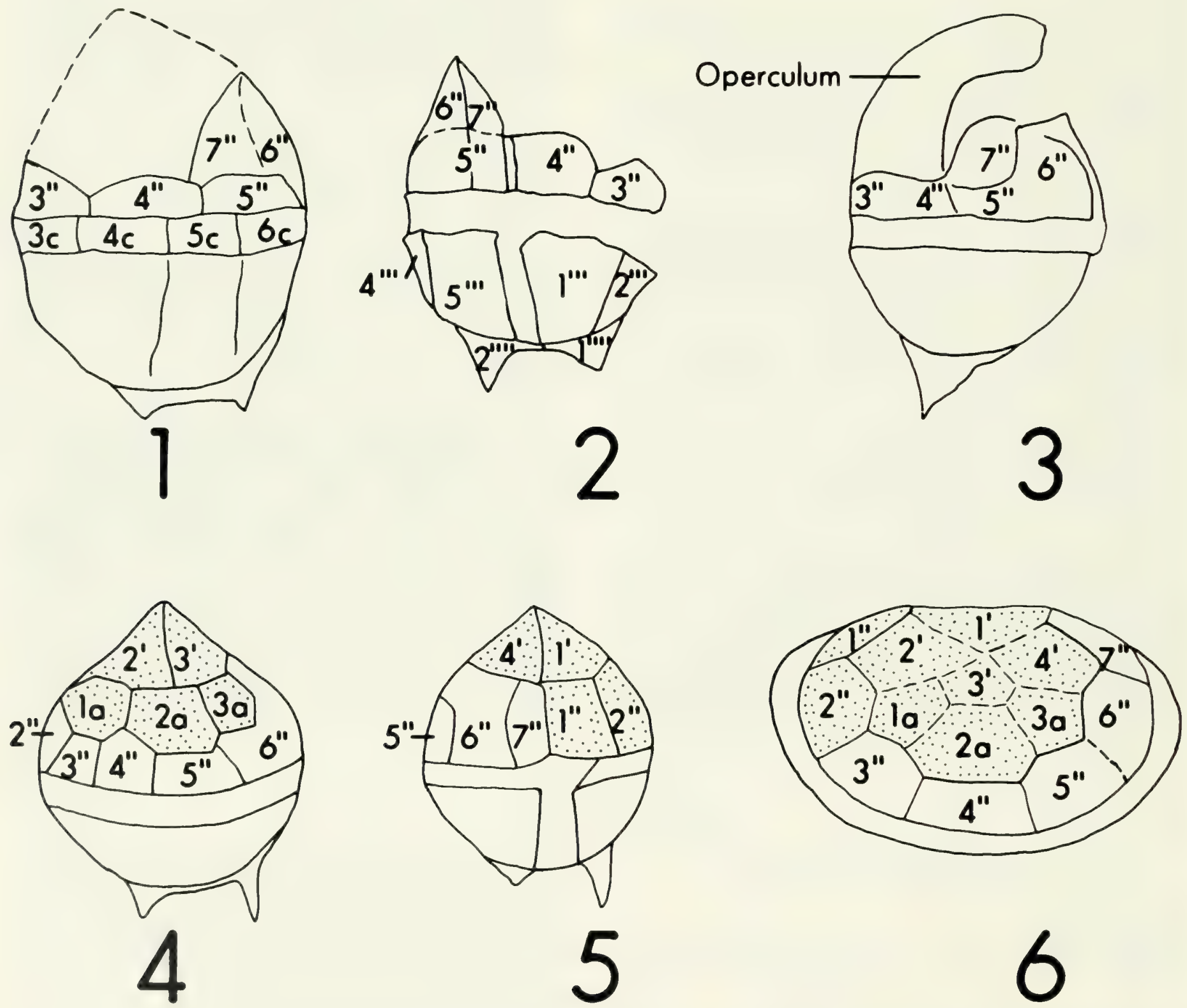

TEXT-FIG. 18. The tabulation and archeopyle of Talimudinium scissurum sp. nov. I, Dorsal view, operculum free, SM-60; A4; 40.7/102.7. 2, Ventral view, operculum free, SM-60; A ; 39.5/100.8. 3, Lateral view, operculum attached, SM-60; A4; 40.9/106.1.4-6, Diagrams of the tabulation and archeopyle of Talimudinium scissurum: 4, dorsal view; 5 , ventral view; 6 , apical view. 
PARATYPE

SM-60; $\mathrm{A}_{4} ; 39.9 / 109.5$. For other details see holotype.

\section{DIAGNOSIS}

Cyst proximate and cavate, typically bicavate with apical horn and two unequally developed antapical horns. Wall thin; periphragm smooth or with scattered granules, delicate and transparent; endophragm sparsely granulate. Endoblast large, subspherical. Low sutural ridges imperfectly developed or absent. Archeopyle transapical, type (tA3I2P), formed by the loss of apical intercalary and two precingular (1", 2") plates. Archeopyle suture zigzag. Cingulum always present, marked by ridges of low to medium height.

\section{DESCRIPTION}

Cyst peridinioid, subspherical in ambital view. Apical horn usually well developed, bluntly pointed, 6 to $10 \mu \mathrm{m}$ high. Two antapical horns weakly to moderately developed, left one always longer and more distinct and pointed than right. Wall thin, less than $1 \mu \mathrm{m}$ thick. Periphragm colourless or very light, not staining readily. Endophragm thicker than periphragm, sparsely granulate; granules usually less than $1 \mu \mathrm{m}$ across. Subspherical endoblast filling major space of pericoel, resulting in ambital pericoel being narrow (about 2 to $3 \mu \mathrm{m}$ ) or even completely absent. Cingulum planar, 4 to $6 \mu \mathrm{m}$ wide, distinctly bounded by low - to medium-height ridges, indenting outline laterally. Sulcus sometimes discernible, restricted to hypotract, defined by low ridges. Tabulation not always indicated; when discernible marked by low and imperfect sutural ridges; probably 4', 3a, 7", $(6-7) \mathrm{C}$, 5", 2"'" (Text-Fig. 18).

\section{DIMENSIONS}

Length 50 to $80 \mu \mathrm{m}$ (holotype $66 \mu \mathrm{m}$ ), width 32 to $50 \mu \mathrm{m}$ (holotype $56 \mu \mathrm{m}$ ); 20 specimens measured.

\section{STRATIGRAPHIC RANGE}

Kukebai Formation to Yigeziya Formation, Zones A to $\mathrm{C}$; rare in Zones $\mathrm{A}$ to $\mathrm{C}$ of Wuluokeqiate section, abundant in Zone $\mathrm{C}$ of Simuhana section; late Cretaceous.

\section{DISCUSSION}

Talimudinium scissurum resembles Palaeoperidinium cretaceum but differs in having a distinct spherical to subspherical endoblast and a transapical combination archeopyle of (tA3I2P). P. cretaceum has a transpical combination archeopyle of (tAtI3P) and usually lacks a distinct endoblast.

\section{Subfamily Wetzelielloideae Vozzhennikova, emend. Bujak and Davies, 1983}

\section{Genus Kisselovia Vozzhennikova, 1967}

\section{Kisselovia fusiformis sp. nov.}

Pl. 13, figs. 2-4

\section{DERIVATION OF NAME}

From the Latin fusus, a spindle, in reference to the spindlelike shape of cysts of this species.

\section{HOLOTYPE}

WG-77; $\mathrm{A}_{1} ; 28.6 / 97.6$. Bashibulake Formation, Wuluokeqiate section (lower Oligocene).

\section{PARATYPE}

WG-77; $A_{1} ; 48.0 / 95.3$. For other details see holotype.

\section{DIAGNOSIS}

Cyst proximochorate, typically cornucavate, rhombic to fusiform at ambitus; with an indistinct apical, one antapical, and two cingular horns. Epitract commonly shorter than hypotract. Periphragm bearing the intratabular processes arranged in simulate complexes and also distributed haphazardly within complexes. Neighbour- ing processes may be connected distally by trabeculae. Process complexes masked by very thin perforate membranes from three directions. Endoblast asymmetrically rhombic, protruding more into the hypotract than the epitract. Archeopyle intercalary, type (I)a, quadra 2a style; operculum seldom free.

\section{DESCRIPTION}

Epitract triangular, with a triangular apical horn merging into the two sides imperceptibly. Hypotract also triangular, with a triangular antapical horn commonly sharper than the apical horn; sometimes the antapical horn divided distally into two small subsidiary, closely adjacent horns, the left being longer and more pointed than the right. The two cingular horns variable in length (usually 8 to $12.5 \mu \mathrm{m}$, up to $17 \mu \mathrm{m}$ ) and shape (from domelike to nipplelike), commonly with broad bases and rounded ends. Both periphragm and endophragm smooth, the cornucavate pericoels connected by very narrow ambital pericoels or none at all. Processes mainly simple and isolated, typically capitate, rarely bifurcate and aculeate distally, expanded proximally, in rare cases the two neighbouring processes connected proximally 
They are usually 0.5 to $1 \mu \mathrm{m}$ in width and 8 to $10 \mu \mathrm{m}$ in length. Masked by very thin and perforate membranes, the simulate process complexes assume the outline of underlying plates. However, the precise tabulation formula cannot be deciphered from them because of the long and randomly oriented processes just within the plate boundary. Cingulum faintly indicated by alignment of processes along the borders and a lack of processes within the cingulum. Archeopyle only occasionally discernible; the operculum commonly attached anteriorly and slightly open posteriorly, the sutures often obscured by the long processes.

\section{DIMENSIONS}

Length 117 to $162.5 \mu \mathrm{m}$ (holotype $120 \mu \mathrm{m}$ ), width 90 to $125 \mu \mathrm{m}$ (holotype $95 \mu \mathrm{m}$ ); 15 specimens measured.

\section{STRATIGRAPHIC RANGE}

Bashibulake Formation, Zone F; common in Zone F of Wuluokeqiate section; early Oligocene.

\section{DISCUSSION}

Kisselovia fusiformis is distinguished by its elongate rhombic pericyst with epitract shorter than the hypotract and by its either indistinct or distally rounded horns. $K$. variabilis Bujak, 1980, also has a rhombic pericyst with a longer hypotract than the epitract; however, it is broader than long and has more complicated process complexes.

\section{Kisselovia wulagenensis sp. nov.}

Pl. 13, figs. 5-10

Kisselovia sp. B, Mao and Norris, 1984, pl. 3, fig. 14

\section{DERIVATION OF NAME}

Named for the Wulagen Formation (upper Eocene), Tarim Basin, Xinjiang Province, China.

\section{HOLOTYPE}

WG-63; $\mathrm{A}_{2} ; 35.5 / 101.5$. Wulagen Formation, Wuluokeqiate section (upper Eocene).

\section{PARATYPE}

WG-63; $\mathrm{A}_{5} ; 30.5 / 101.5$. For other details see holotype.

\section{DIAGNOSIS}

Cyst proximochorate, circumcavate. Ambitus roundedrhombic to rounded-pentagonal, with slightly prominent apex and two poorly developed antapical horns. Periphragm bearing penitabular processes connected distally by trabeculae and encircled penitabularly by thin membranes to form simulate complexes. Endoblast large, almost filling the whole pericoel. Tabulation typically peridinioid, indicated by the penitabular process complex; 4', 3a, 7", XC, 5"', 2"'". Archeopyle intercalary, type (I)a, quadra 2a style; operculum attached anteriorly.

\section{DESCRIPTION}

Epitract triangular, almost equal to the triangular-trapezoid hypotract. Antapical horns reduced to shallow lobes or small triangles. Periphragm smooth; endophragm smooth to granulate. Processes simple and solid, capitate or bifurcate distally, 3 to $7 \mu \mathrm{m}$ long and 0.5 to $1 \mu \mathrm{m}$ across, arranged penitabularly in one row in each complex, connected distally by trabeculae, encircled and connected by very thin membranes to form complete complexes simulating the plate. Sporadic intratabular processes also possibly occurring. Solid trabeculae possibly transforming gradually and proximally into thin and transparent membranes seen on the profile. Not clear whether the membranes covering or not covering the top of the fenced areas. The small apical and antapical pericoels are connected by 1-to- $2-\mu \mathrm{m}$-wide ambital pericoel related to the large subspherical to rounded-rhombic endoblast. Sulcus restricted to the hypotract.

\section{DIMENSIONS}

Length 85 to $105 \mu \mathrm{m}$ (holotype $90 \mu \mathrm{m}$ ), width 67 to 103 $\mu \mathrm{m}$ (holotype $76 \mu \mathrm{m}$ ); 15 specimens measured.

\section{STRATIGRAPHIC RANGE}

Wulagen Formation, Zone E; abundant in Zone $\mathrm{E}$ of Wuluokeqiate section; late Eocene.

\section{DISCUSSION}

Kisselovia wulagenensis differs from K.(?) clathrata (Eisenack, 1938) and K. coleothrypta (Williams and Downie, 1966c), in having one row of penitabular processes united distally by trabeculae and encircled by membranes; the other two species have numerous intratabular processes connected distally by a perforate membrane.

\section{Genus Wetzeliella Eisenack, 1938}

\section{Wetzeliella crassa sp. nov.}

Pl. 15, figs. 1,2

\section{DERIVATION OF NAME}

From the Latin crassus, thick, dense, with reference to the long and densely distributed processes that characterize this species.

\section{HOLOTYPE}

QF-79; $A_{1} ; 45.0 / 101.7$. Wulagen Formation, Qimugen section (upper Eocene). 


\section{PARATYPE}

QF-79; $A_{1} ; 40.4 / 99.3$. For other details see holotype.

\section{DIAGNOSIS}

Cyst proximochorate, typically cornucavate, transversely rhombic in ambitus, and large in size (more than $100 \mu \mathrm{m}$ in width). Apical horn obtusely triangular, two cingular horns and one antapical horn variably developed. Periphragm bearing isolated, densely distributed, mainly simple nontabular processes. Endophragm separated from the periphragm only at the bases of the horns. Archeopyle intercalary, type (I)a, quadra style. Operculum usually attached.

\section{DESCRIPTION}

Cyst transversely rhombic to spindlelike, symmetrical, width greater than length. One antapical horn located in the central line, nipplelike, up to 18 to $20 \mu \mathrm{m}$ long. Two cingular horns possibly developed as short prominences or else long (up to $20 \mu \mathrm{m}$ ) and nipplelike. The periphragm bearing numerous nontabular processes possibly acuminate, capitate or (rarely) bifurcate distally, expanded proximally. Processes usually 8 to $12 \mu \mathrm{m}$ long (up to a maximum of $18 \mu \mathrm{m}$ ), hollow or solid, more densely distributed near the horns than elsewhere. Pericoels developed only in very small areas beneath the horns. Archeopyle hardly discernible, partly because of the randomly distributed dense processes. Operculum attached anteriorly, leaving the posterior suture slightly open.

\section{DIMENSIONS}

Length 60 to $102 \mu \mathrm{m}$ (holotype $70 \mu \mathrm{m}$ ), width 105 to 165 $\mu \mathrm{m}$ (holotype $117 \mu \mathrm{m}$ ); 9 specimens measured (many other distorted specimens examined).

\section{STRATIGRAPHIC RANGE}

Wulagen Formation; rare in Zone E of Qimugen section; late Eocene.

\section{DISCUSSION}

Wetzeliella crassa sp. nov. is distinguished by its spindlelike shape and long densely distributed processes. It is similar to W. symmetrica Weiler, 1956, but differs in having a pericyst with its width greater than its length and in having a periphragm bearing denser and longer processes.

\section{Wetzeliella sp. A \\ PI. 15, figs. 6,7}

\section{DESCRIPTION}

Cyst circumcavate to cornucavate, with a pentagonal ambitus. Apical horn distinct, about $10 \mu \mathrm{m}$ long. The two antapical horns equal or slightly unequal, with left one longer. The two lateral horns usually truncated and almost the same length as the other three horns, but wider at their bases. Endoblast spherical, occupying the major portion of the pericoel and leaving a 0 -to-5- $\mu \mathrm{m}$ wide ambital pericoel between the two layers. Periphragm smooth to granulate, bearing simple, isolated, and bluntly pointed nontabular processes. Processes long $(8$ to $10 \mu \mathrm{m})$ and thin (0.5 to $1 \mu \mathrm{m}$ across) but wider at their bases ( 2 to $2.5 \mu \mathrm{m}$ ), tapering rapidly from 2 to $2.5 \mu \mathrm{m}$ at the bases to 0.5 to $1 \mu \mathrm{m}$ wide within a 1 to $2 \mu \mathrm{m}$ distance. As a result, in almost all the specimens observed (which are not well preserved), most of the processes are artificially short, these being, in fact, the basal part of the processes, with the main parts broken off. Archeopyle intercalary, type I, quadra 2a soleiform; operculum attached anteriorly (along side $\mathrm{Q}_{1}$ ) or free. Indications of tabulation, other than archeopyle, absent.

\section{DIMENSIONS}

Length 91 to $125 \mu \mathrm{m}$, width 69 to $110 \mu \mathrm{m}$; 9 specimens measured.

\section{STRATIGRAPHIC RANGE}

Wulagen Formation, Zone E; common in Zone E of Wuluokeqiate and Qimugen sections; late Eocene.

\section{DISCUSSION}

This species is characterized by a pentagonal pericyst with five moderately developed horns, a large spherical endoblast, a periphragm bearing long and thin nontabular processes, and a quadra-2a-soleiform archeopyle. Wetzeliella sp. A is a distinct species but has not been formally named at present because of the lack of wellpreserved specimens.

\section{Family Protoperidiniaceae \\ Subfamily Senegalinioideae Bujak and Davies, 1983}

\section{Genus Phelodinium Stover and Evitt, 1978, emend. nov.}

Phelodinium Stover and Evitt, 1978:118
TYPE SPECIES

Phelodinium pentagonale (Corradini, 1973) Stover and Evitt, 1978; upper Cretaceous (Senonian), northern Apennines, Italy. 


\section{EMENDED DIAGNOSIS}

Cyst proximate, typically cornucavate, compressed peridinioid, subrhomboidal to pentagonal in ambital view. One apical and one or two antapical horns always present and usually pointed. Periphragm and endophragm smooth or with features of low relief; the former thinner than the latter. Endoblast slightly to strongly prominent at the bases of the three horns. Pericoels typically small and narrow. Cingulum always discernible, its margins being indicated by low ridges or folds. Archeopyle intercalary, type (I), standard hexa $2 \mathrm{a}$, typically with antapical margin close to the cingulum; AI 0.3 to 0.6 . Indications of tabulation, other than archeopyle and cingulum, absent.

\section{DISCUSSION}

The above-emended diagnosis of Phelodinium augments the information pertaining to the archeopyle. The archeopyle index of Phelodinium according to Stover and Evitt (1978:117) is 0.3 to 0.4 . In the present study, 30 specimens of Phelodinium were observed; these have the typical morphological features for Phelodinium but have an archeopyle index greater than 0.4 (usually 0.4 to 0.5 , occasionally up to 0.6 ), the archeopyle being essentially of standard hexa style. Thus, the generic diagnosis is here extended to encompass such forms.

\section{Phelodinium anisos sp. nov.}

Pl. 15, figs. 14-16

Phelodinium sp. A, Mao and Norris, 1984, pl. 2, fig. 6

\section{DERIVATION OF NAME}

From the Greek anisos, unbalanced, in reference to the asymmetrical appearance of the cysts of this species.

\section{HOLOTYPE}

QF-49; $\mathrm{A}_{3} ; 43.0 / 107.7$. Qimugen Formation, Qimugen section (upper Paleocene).

\section{PARATYPE}

QF-47; $\mathrm{A}_{2} ; 26.8 / 96.5$. Qimugen Formation, Qimugen section (upper Paleocene).

\section{DIAGNOSIS}

Cyst proximate, cornucavate, with a subrhombic to pentagonal ambitus. Apical horn and left antapical horn well developed and pointed; right antapical horn reduced or absent. Periphragm very thin, smooth, and transparent; separated from the endophragm only at the bases of the horns, appressed elsewhere. Endoblast rhombic to pentagonal, with four angles at apical, two lateral, and left antapical regions. Archeopyle intercalary, type (I), standard hexa $2 \mathrm{a}$, with transverse AI 0.5 to 0.6 ; operculum free or attached posteriorly.

\section{DESCRIPTION}

Cyst subrhombic, squarish and subpentagonal in ambital view, length greater than width. Epitract triangular, with straight or slightly convex sides; hypotract with a subtriangular to trapezoidal ambitus. Ambitus asymmetrical laterally, with only the left antapical horn well developed; the right antapical horn reduced to a small size or completely absent. Apical and left antapical horns (which are up to 10 and $7 \mu \mathrm{m}$ long respectively) distinct and pointed. Periphragm separated from the endophragm only at the bases of either all the horns or one or two of the horns; very thin, smooth, transparent, and delicate in appearance. Endophragm also smooth and thin but thicker than periphragm. Endoblast typically with blunted or rounded horns, whereas periphragm usually drawn out and separated from the endophragm to produce pointed horns. Cingulum planar to slightly helicoid, marked by folds.

\section{DIMENSIONS}

Length (including horns) 63 to $80 \mu \mathrm{m}$ (holotype $75 \mu \mathrm{m}$ ), width 40 to $53 \mu \mathrm{m}$ (holotype $48 \mu \mathrm{m}$ ); 30 specimens measured.

\section{STRATIGRAPHIC RANGE}

Qimugen Formation to Wulagen Formation, Zones D to $\mathrm{E}$; abundant in Zone D of Qimugen section, common in Zone D of Simuhana section, and rare in Zone E of Qimugen section; late Paleocene to late Eocene.

\section{DISCUSSION}

Phelodinium anisos sp. nov. differs from $P$. pumilum Liengjarern, Costa, and Downie, 1980, in having a very thin and delicate periphragm, pointed apical and anatapical horns, and an endoblast also bearing horns. 


\section{Subfamily Incerta}

\section{Genus Pseudoalterbia gen. nov.}

\section{DERIVATION OF NAME}

From the Latin pseudo, false, in reference to the fact that cysts in this genus resemble those of Alterbidinium but are not cavate.

\section{TYPE SPECIES}

Pseudoalterbia concinna sp. nov., late Cretaceous.

\section{DIAGNOSIS}

Cyst proximate, pentagonal, with slightly protruding apical and left antapical horns; apical horn usually bluntly pointed, left antapical horn commonly pointed, and right antapical horn greatly reduced or absent. Epitract triangular in ambital view, with two sides convex; hypotract more or less trapezoidal and asymetrical about the longitudinal axis; the two parts almost equal in size. Autophragm smooth or with scattered, normally isolated features of low relief. Cingulum well defined by medium-height ridges, planar to slightly helical. Archeopyle intercalary, type I, standard to attenuate hexa $2 \mathrm{a}$ style, transverse AI less than 0.5 ; operculum detached or attached along its posterior margin.

\section{DISCUSSION}

Pseudoalterbia differs from Lejeunecysta (Gerlach, 1961) and Xuidinium gen. nov. in having an asymetrical subpentagonal ambitus with only one distinct and pointed left antapical horn and a well-defined cingulum. It differs from Alterbidinium Lentin and Williams, 1985, in having an autophragm rather than a separated periphragm and endophragm. The endoblasts of cavate cysts, such as Alterbidinium or Phelodinium, are not known to bear apical horns as pointed as those found in Pseudoalterbia, which, therefore, is certainly a valid genus rather than a free endoblast of some cavate cyst.

\section{Pseudoalterbia concinna sp. nov.}

Pl. 16, figs. 4-6

Alterbia acuminata Morgan, 1980 auct. non (Cookson and Eisenack) Lentin and Williams, 1976, pl. 32, fig. 1

\section{DERIVATION OF NAME}

From the Latin concinnus, beautiful, in reference to the appearance of the cysts of this species.

\section{HOLOTYPE}

WG-18; $\mathrm{A}_{2} ; 46.0 / 97.2$. Kukebai Formation, Wuluokeqiate section (upper Cretaceous).

\section{PARATYPE}

WG-18; $\mathrm{A}_{5} ; 43.7 / 95.5$. For details see holotype.

\section{DIAGNOSIS}

A species of Pseudoalterbia having a pentagonal or subrhomboidal cyst with an apical horn and a left antapical horn.

\section{DESCRIPTION}

Cyst proximate, pentagonal in ambital view. Epitract having a triangular ambitus, with a short rounded apical horn and slightly convex sides. Hypotract approximally triangular or irregularly trapezoidal in ambital view with only a pointed left antapical horn; right antapical horn never developed. Structures posterior to apical horn similar to the subapical thickening and quasi-tabular ridges observed by Norris and Hedlund (1972:50-52) in their Palaeoperidinium from the Albian of Oklahoma. Autophragm thin, smooth or finely granulate; commonly folded, most folds being short and parallel to the long axis of the cyst. Cingulum clearly defined by ridges; planar or slightly helical and dividing the cyst into two almost equal parts. Archeopyle intercalary, type (I), hexa style, AI 0.37 to 0.47 (holotype 0.44 ); operculum detached or attached posteriorly.

\section{DIMENSIONS}

Length 56 to $83 \mu \mathrm{m}$ (holotype $62 \mu \mathrm{m}$ ), width 36 to $63 \mu \mathrm{m}$ (holotype $45 \mu \mathrm{m}$ ); 13 specimens measured.

\section{STRATIGRAPHIC RANGE}

Kukebai Formation, Zone B; abundant in Zone B of Wuluokeqiate section; Turonian to Coniacian or to Santonian.

\section{DISCUSSION}

The shape of this species is very similar to that of the genus Alterbidinium, but it has a proximate rather than a cavate cyst.

\section{Genus Xuidinium gen. nov.}

\section{DERIVATION OF NAME}

Named in honour of Dr. R. Xu, Institute of Botany, Academia Sinica, Beijing, the pioneer of palynology in China. We have chosen the standard Pinyin romanization of this name, which in other systems, however, is sometimes rendered $\mathrm{Hsu}, \mathrm{J}$.

\section{TYPE SPECIES}

Xuidinium laevigatum sp. nov., late Paleocene 
DIAGNOSIS

Cyst proximate; ambitus rounded biconical with an apical and an antapical prominence, right antapical part either without horn or slightly bulging. Autophragm smooth or uniformly ornamented with features of low relief. Tabulation indicated by archeopyle only or by archeopyle and cingulum together. Archeopyle intercalary, type I, hexa $2 \mathrm{a}$.

\section{DISCUSSION}

Xuidinium is characterized by a biconical autocyst and a hexa-2a intercalary archeopyle. It differs from Pyxidiella in having both apical and antapical prominences rather than two broad rounded ends. Pseudoalterbia gen. nov. also has an autocyst with an apical and a left antapical horn. In Pseudoalterbia, however, the cingulum is much more distinct than in Xuidinium, and the left antapical horn is more prominent and pointed and more divergent from the longitudinal axis, whereas in Xuidinium, the shape of the autocyst is almost symmetrical about its longitudinal axis, and the cingulum is weakly indicated or not present.

\section{Xuidinium laevigatum sp. nov.}

Pl. 16, figs. 7-11

\section{DERIVATION OF NAME}

From the Latin laevigata, smooth, with reference to the smooth wall surface.

\section{HOLOTYPE}

SM-77; $A_{1} ; 39.7 / 101.8$. Qimugen Formation, Simuhana section (upper Paleocene).

\section{PARATYPE}

QF-43; $A_{2} ; 43.6 / 98.7$. Qimugen Formation, Qimugen section (upper Paleocene).

\section{DIAGNOSIS}

Cyst proximate, ambitus rounded-biconical to ovoidal with an apical prominence and a small left antapical prominence. Autophragm smooth and thin. Archeopyle intercalary, type I, standard hexa-2a style.

\section{DESCRIPTION}

Epitract triangular with two sides convex, into which the apical prominence merges imperceptibly. Hypotract equal in size to epitract, semielliptical to rounded-triangular with a small left antapical prominence near the longitudinal axis. Autophragm slightly bulging at the presumed position of the right antapical horn. Autophragm thin and smooth, readily folded, slightly distorting the ambitus. Tabulation indicated by archeopyle only or by both archeopyle and cingulum. The latter, when discernible, defined by folds. Archeopyle standard hexa style; transverse AI 0.4 to 0.6 . In one specimen the open sutures indicate a 3I archeopyle, which may be an archeopyle variation of this species.

\section{DIMENSIONS}

Length 51 to $64 \mu \mathrm{m}$ (holotype $56 \mu \mathrm{m}$ ), width 37 to $52 \mu \mathrm{m}$ (holotype $43 \mu \mathrm{m}$ ); 15 specimens measured.

\section{STRATIGRAPHIC RANGE}

Qimugen Formation, Zone D; common in Zone D of both Qimugen and Simuhana sections; late Paleocene.

\section{Acknowledgements}

We are grateful to Professor Zeng Xuelu of Wuhan College of Geology for collecting most of the samples and also to Fei Anwei and the late Wu Naiying of Beijing Graduate School of Wuhan College of Geology for sharing some of their samples.

We acknowledge with thanks help from the following: Dr. Robert Fensome and Martin Head for continuing discussion and careful critical comments on the manuscript, Dr. Jon Bujak and Dr. Graham L. Williams for constructive criticism and many helpful comments and suggestions, two anonymous reviewers, Mrs. Cynthia H. Millar-Campbell of the Royal Ontario Museum for providing considerable assistance in final plate prepa- ration, Mrs. Leysa Ligaya for skillful word processing, and Mr. P. Brian O'Donovan for photographic assistance.

We acknowledge an operating grant from the Natural Sciences and Engineering Research Council of Canada (principal investigator G. Norris) and funding from the Ministry of Education of the People's Republic of China to S. Mao, which made this study possible.

It is a pleasure to acknowledge helpful advice and assistance received from Dr. Peter von Bitter of the Royal Ontario Museum during the preparation of this paper and from Barbara Ibronyi during her skillful editing of the manuscript. 


\section{Literature Cited}

ALBERTI, G

1959 Zur Kenntnis der Gattung Deflandrea Eisenack (Dinoflag.) in der Kreide und Alttertiär Nord- und Mitteldeutschlands. Mitteilungen aus dem Geolo gischen Staatsinstitut in Hamburg 28:93-105.

1961 Zur Kenntnis mesozoischer und alttertiärer Dino flagellaten und Hystrichosphaerideen von Nordund Mitteldeutschland sowie einigen anderen europäischen Gebieten. Palaeontographica (Abt. A) 116:1-58.

ARCHANGELSKY, $S$.

1969 Sobre el paleomicroplancton del Terciario, inferior de Río Turbio, Provincia de Santa Cruz. Ameghiniana 5:406-416.

ARTZNER, D. G., E. H. DAVIES, G. DÖRHÖFER, A. FASOLA, G. NORRIS, and S. POPLAWSKI

1979 A systematic illustrated guide to fossil organic walled dinoflagellate genera. Life Sciences Miscellaneous Publications. Toronto, Royal Ontario Museum. $119 \mathrm{pp}$.

ARTZNER, D. G. and G. DÖRHÖFER

1978 Taxonomic note: Lejeunecysta nom. nov. pro. Lejeunia Gerlach 1961 emend. Lentin and Williams 1976 - dinoflagellate cyst genus. Canadian Journal of Botany 56:1381-1382.

BELOW, $\mathbf{R}$.

1981 Dinoflagellaten-zysten aus dem oberen Hauterive bis unteren Cenoman Süd-West-Marokkos. Palaeontographica (Abt. B) 176:1-145.

BENEDEK, P. N

1972 Phytoplanktonten aus dem Mittel- und Oberoligozän von Tönisberg (Niederrheingebiet). Palaeontographica (Abt. B) 137:1-71.

BERGGREN, W. A., D. V. KENT, J. J. FLYNN, and J. A. COUVERING

1985 Cenozoic geochronology. Geological Society of America, Bulletin 96:1407-1418

BRIDEAUX, W. W

1971 Palynology of the Lower Colorado Group, central Alberta, Canada, I. Introductory remarks. Geology and microplankton studies. Palaeontographica (Abt. B) 135:53-114.

BROSIUS, $\mathrm{M}$

1963 Plankton aus dem nordhessischen Kasseler Meeressand (Oberoligozän). Zeitschrift der Deutschen Geologischen Gesellschaft 114:32-56.

BUJAK, J.P.

1976 An evolutionary series of Late Eocene dinoflagellate cysts from southern England. Marine Micropaleontology 1:101-117.

1979 Proposed phylogeny of the dinoflagellates Rhombodinium and Gochtodinium. Micropaleontology 25:308-324.

1980 Dinoflagellate cysts and acritarchs from the Eocene Barton Beds of southern England. In Bujak, J. P., C. Downie, G. L. Eaton, and G. L. Williams, Dinoflagellate cysts and acritarchs from the Eocene of southern England. Special Papers in Palaeontology 24:36-91.

BUJAK, J. P. and E. H. DAVIES

1983 Modern and fossil Peridinieae. American Associa tion of Stratigraphic Palynologists, Contribution Series 13:1-203.

BUJAK, J. P., C. DOWNIE, G. L. EATON, AND G. L. WILLIAMS

1980a Dinoflagellate cysts and acritarchs from the Eocene of southern England. Special Papers in Palaeontol ogy $24: 1-100$.

1980b Taxonomy of some Eocene dinoflagellate cyst species from southern England. In Bujak, J. P., C. Downie, G. L. Eaton, and G. L. Williams, Dinoflagellate cysts and acritarchs from the Eocene of southern England. Special Papers in Palaeontology $24: 26-35$.

BUJAK, J. P. and G. L. WILLIAMS

1978 Cretaceous palynostratigraphy of offshore southeastern Canada. Geological Survey of Canada, Bulletin 297:1-18.

CHATEAUNEUF, $\mathbf{J}_{-}-\mathrm{J}$.

1980 Palynostratigraphie et paléoclimatologie de l'Éocène supérieur et de l'Oliogocène du Bassin de Paris (France). Bureau de Recherches Géologiques et Minières, Mémoire 16:1-360.

CLARKE, R. F. A. and J.-P. VERDIER

1967 An investigation of microplankton assemblages from the Chalk of the Isle of Wight, England. Verhandelingen der Koninklijke Nederlands Akademie van Wetenschappen, Afdeeling natuurkunde, Series 1, 24:1-96.

COOKSON, I. C.

1956 Additional microplankton from Australian Late Mesozoic and Tertiary sediments. Australian Journal of Marine and Freshwater Research 7:183-191.

1965 Cretaceous and Tertiary microplankton from southeastern Australia. Proceedings of the Royal Society of Victoria 78:85-93.

COOKSON, I. C. and A. EISENACK

1958 Microplankton from Australian and New Guinea Upper Mesozoic sediments. Proceedings of the Royal Society of Victoria 70:19-79.

1960a Microplankton from Australian Cretaceous sediments. Micropaleontology 6:1-18.

1960b Upper Mesozoic microplankton from Australia and New Guinea. Palaeontology 2:243-261.

1961 Tertiary microplankton from the Rottnest Island Bore, Western Australia. Journal of the Royal Society of Western Australia 44:39-47.

1962 Additional microplankton from Australian Creta. ceous sediments. Micropaleontology 8:485-507.

1965 Microplankton from the Browns Creek Clays, southwestern Victoria. Proceedings of the Royal Society of Victoria 79:119-131.

1967 Some microplankton from the Paleocene River. 
nook Bed, Victoria. Proceedings of the Royal Society of Victoria 80:247-257.

1970 Cretaceous microplankton from the Eucla Basin, Western Australia. Proceedings of the Royal Society of Victoria 83:137-157.

1971 Cretaceous microplankton from Eyre No. 1 Bore Core 20, Western Australia. Proceedings of the Royal Society of Victoria 84:217-226.

1974 Microplankton aus australischen mesozoischen und tertiären Sedimenten. Palaeontographica (Abt. B) 148:44-93.

COOKSON, I. C. and N. F. HUGHES

1964 Microplankton from the Cambridge Greensand (mid-Cretaceous). Palaeontology 8:37-59.

CORRADINI, D.

1973 Non-calcareous microplankton from the Upper Cretaceous of the Northern Apennines. Bollettino della Societa Paleontologica Italiana 11:119-197.

COSTA, L. I. and C. DOWNIE

1976 The distribution of the dinoflagellate Wetzeliella in the Palaeogene of north-western Europe. Palaeontology 19:591-614.

1979 The Wetzeliellaceae; Palaeogene dinoflagellates. In Proceedings of the Fourth International Palynological Conference, Lucknow, 1976-1977, vol. 2, pp. 34-36.

DALE, $B$.

1983 Dinoflagellate resting cysts: "benthonic plankton.” In Fryxell, G. A., ed., Survival strategies of the algae. Cambridge, Cambridge University Press, pp. 69-129.

DAVEY, R. J.

1969 Non-calcareous microplankton from the Cenomanian of England, north France and North America, Part I. Bulletin of the British Museum (Natural History) Geology 17:103-180.

1970 Non-calcareous microplankton from the Cenomanian of England, northern France and North America, Part II. Bulletin of the British Museum (Natural History) Geology 18:333-397.

1974 Dinoflagellate cysts from the Barremian of the Speeton Clay, England. Birbal Sahni Institute of Palaeobotany, Special Publication 3:41-75.

1978 Marine Cretaceous palynology of Site 361, DSDP Leg 40, off southwestern Africa. In Bolli, H. M., W. B. F. Ryan, et al., Initial Reports of the Deep Sea Drilling Project. Washington, vol. 40, pp. 883-913.

1979 Marine Apto-Albian palynomorphs from Holes 400A and 402A, IPOD Leg 48, northern Bay of Biscay. In Montadert, L., D. G. Roberts, et al., Initial Reports of the Deep Sea Drilling Project. Washington, vol. 48, pp. 547-577.

DAVEY, R. J., C. DOWNIE, W. A. S. SARJEANT, and G. L. WILLIAMS

1966 Studies on Mesozoic and Cainozoic dinoflagellate cysts. Bulletin of the British Museum (Natural History) Geology, Supplement 3:1-248.

1969 Generic reallocations proposed jointly by R. J. Davey, C. Downie, W. A. S. Sarjeant, and G. L.
Williams. In Davey, R. J., C. Downie, W. A. S. Sarjeant, and G. L. Williams, Appendix to "Studies on Mesozoic and Cainozoic dinoflagellate cysts." Bulletin of the British Museum (Natural History) Geology, Appendix to Supplement 3:15-17.

DAVEY, R. J. and J. ROGERS

1975 Palynomorph distribution in Recent offshore sediments along two traverses off South West Africa. Marine Geology 18:213-225.

DAVEY, R. J. and J.P. VERDIER

1973 An investigation of microplankton assemblages from latest Albian (Vraconian) sediments. Revista Española Micropaleontologia 5:173-212.

1974 Dinoflagellate cysts from the Aptian type sections at Gargas and La Bedoule, France. Palaeontology 17:623-653.

DAVEY, R. J. and G. L. WILLIAMS

1966a The genera Hystrichosphaera and Achomosphaera. In Davey, R. J., C. Downie, W. A. S. Sarjeant, and G. L. Williams, Studies on Mesozoic and Cainozoic dinoflagellate cysts. Bulletin of the British Museum (Natural History) Geology, Supplement 3:28-52.

1966b The genus Hystrichosphaeridium and its allies. In Davey, R. J., C. Downie, W. A. S. Sarjeant, and G. L. Williams, Studies on Mesozoic and Cainozoic dinoflagellate cysts. Bulletin of the British Museum (Natural History) Geology, Supplement 3:53-105.

1969 Generic reallocations. In Davey, R. J., C. Downie, W. A. S. Sarjeant, G. L. Williams, Appendix to "Studies on Mesozoic and Cainozoic dinoflagellate cysts." Bulletin of the British Museum (Natural History) Geology, Appendix to Supplement 3:4-7. DEFLANDRE, $\mathrm{G}$

1935 Considérations biologiques sur les microorganismes d'origine planctonique conservés dans les silex de la craie. Bulletin biologique de la France et de la Belgique 69:213-244.

1937 Microfossiles des silex crétacés; deuxième partie, flagellés incertae sedis, Hystrichosphaeridés, Sarcodinés, organismes divers. Annales de paléontologie 26:51-103.

1941 Le microplancton kiméridgien d'Orbagnoux et l'origine des huiles sulfurées naturelles. Mémoires de l'Academie des Sciences, Paris 65:1-32.

1947 Sur quelques microorganismes planctoniques des silex jurassiques. Bulletin de l'Institut Océanographique de Monaco 921:1-10.

DEFLANDRE, G. and I. C. COOKSON

1955 Fossil microplankton from Australian Late Mesozoic and Tertiary sediments. Australian Journal of Marine and Freshwater Research 6:242-313.

DÖRHÖFER, G. and E. H. DAVIES

1980 Evolution of archeopyle and tabulation in Rhaetogonyaulacinean dinoflagellate cysts. Life Sciences Miscellaneous Publications. Toronto, Royal Ontario Museum. 91 pp. 
DOWNIE, C., W. R. EVITT, and W. A. S. SARJEANT

1963 Dinoflagellates, hystrichosphaeres and the classification of the Acritarchs. Publications of Stanford University, Geological Sciences 7(3):1-16.

DOWNIE, C., M. A. HUSSAIN, and G. L. WILLIAMS

1971 Dinoflagellate cyst and acritarch association in the Palaeogene of south-east England. Geoscience and Man 3:29-35.

DOWNIE, C. and W. A. S. SARJEANT

1963 On the interpretation and status of some hystrichosphere genera. Palaeontology 6:83-96.

1964 Bibliography and index of fossil dinoflagellates and acritarchs. Geological Society of America, Memoir 94:1-180.

DRUGG, W. S.

1967 Palynology of the Upper Moreno Formation (Late Cretaceous-Paleocene) Escarpado Canyon, California. Palaeontographica (Abt. B) 120:1-71.

1970a Two new Neogene species of Tuberculodinium and one of Xenicodinium (Pyrrhophyta). Proceedings of the Biological Society of Washington 83:115122.

$1970 \mathrm{~b}$ Some new genera, species, and combinations of phytoplankton from the Lower Tertiary of the Gulf Coast, U.S.A. In Proceedings of the North American Paleontological Convention, Chicago, 1969, Part G, pp. 809-843.

DUXBURY, S.

1977 A palynostratigraphy of the Berriasian to Barremian of the Speeton Clay of Speeton, England. Palaeontographica (Abt. B) 160:17-67.

1980 Barremian phytoplankton from Speeton, east Yorkshire. Palaeontographica (Abt. B) 173:107146.

EATON, G. L.

1971 A morphogenetic series of dinoflagellate cysts from the Bracklesham Beds of the Isle of Wight, Hampshire, England. In Farinacci, A., ed., Proceedings of the Second Planktonic Conference, Rome, 1970. Rome, Edizioni Technoscienza, vol. 1, pp. 355379.

1976 Dinoflagellate cysts from the Bracklesham Beds (Eocene) of the Isle of Wight, southern England. Bulletin of the British Museum (Natural History) Geology 26:227-332.

EHRENBERG, C. G.

1836 Mittheilungen üben die in den Feuersteinen bei Delitzsch vorkommenden microskopischen Algen und Bryozoen als Begleiter der fossilien Infusorien. Preussische Akademie Wissenschaften Berlin, Bericht Verh. 1836:114-115.

1837 Über die fossilen Infusorien-Gattungen Xanthidium und Peridinium. Archiv für Naturgeschiechte 3:273-278.

1838 Über das Massenverhältnis der jetzt labenden Kiesel Infusorien und uber ein neues InfusorienCongolomerat als Polierschiefer von Jastraba in Ungarn. Abhandlungen der Preussischen Akademie der Wissenschaften, 1836:109-135.
EISENACK, A.

1938 Die Phosphoritknollen der Bernsteinformation als Überlieferer tertiären Planktons. Schriften der Physikalisch-Ökonomische Gesellschaft zu Königsberg 70:181-188.

1954 Mikrofossilien aus Phosphoriten des samland. ischen Unteroligozäns und über die Einheitlichkeit der Hystrichosphaerideen. Palaeontographica (Abt. A) 105:49-95.

1958 Mikroplankton aus dem norddeutschen Apt. Neues Jahrbuch für Geologie und Paläontologie, Abhandlungen 106:383-422.

1961 Einige Eröterungen über fossile Dinoflagellaten nebst Übersicht über die zur Zeit bekannten Gattungen. Neues Jahrbuch für Geologie und Paläontologie, Abhandlungen 112:281-324.

1967 Katalog der fossilen Dinoflagellaten, Hystrichosphäeren und verwandten Mikrofossilien. Band 1. Dinoflagellaten. 1. Ergänzungslieferung. Stuttgart, E. Schweizerbart'sche. 241 pp.

1972 Kritische Bemerkung zur Gattung Pterospermopsis (Chlorophyta, Prasinophyceae). Neues Jahrbuch für Geologie und Paläontologie, Monatshefte 1972:596-601.

EISENACK, A. and I. C. COOKSON

1960 Microplankton from Australian Lower Cretaceous sediments. Proceedings of the Royal Society of Victoria 72:1-11.

EISENACK, A. and H. GOCHT

1960 Neue Namen für einige Hystrichosphären der Bernsteinformation Ostpreussens. Neues Jahrbuch für Geologie und Paläontologie, Monatshefte 1960:511-518.

EISENACK, A. and G. KJELLSTRÖM

1971 Katalog der fossilen Dinoflagellaten, Hystrichosphäeren und verwandten Mikrofossilien. Band II. Dinoflagellaten. 2. Ergänzungslieferung. Stuttgart, E. Schweizerbart'sche. 251 pp.

ELSIK, W. C

1977 Paralecaniella indentata (Deflandre and Cookson 1955) Cookson and Eisenack 1970 and allied dynocysts. Palynology 1:95-102.

EVITT, W. R.

1963 A discussion and proposals concerning fossil dinoflagellates, hystrichospheres, and acritarchs I. Proceedings of the National Academy of Sciences of the United States of America 49:158-164, 298302.

FOUCHER, J. C.

1972 Étude micropaléontologique des silex coniaciens du puits 19 de Lens-Lievin (Pas-de-Calais). Bulletin du Muséum National d'Histoire Naturelle, Paris, $3^{\mathrm{e}}$ sér. 21, Sciences de la terre 5:77-158.

1974 Microfossiles des silex du Turonien supérieur de Ruyaulcourt (Pas-de-Calais). Annales de paléon. tologie (invertébrés), Paris, 60:113-164.

FRITSCH, F. E

1929 Evolutionary sequence and affinities among Protophyta. Biological Reviews 4:104-151. 
GERLACH. E.

1961 Mikrofossilien aus dem Oligozän und Miozän Nordwestdeutschlands, unter besonderer Berücksichtigung der Hystrichosphären und Dinoflagellaten. Neues Jahrbuch für Geologie und Paläontologie, Abhandlungen 112:143-228.

GITMEZ, G. U.

1970 Dinoflagellate cysts and acritarchs from the basal Kimmeridgian (Upper Jurassic) of England, Scotland and France. Bulletin of the British Museum (Natural History) Geology 18:231-331.

GITMEZ, G. U. and W. A. S. SARJEANT

1972 Dinoflagellate cysts and acritarchs from the Kimmeridgian (Upper Jurassic) of England, Scotland and France. Bulletin of the British Museum (Natural History) Geology 21:171-257.

GOCHT, $\mathrm{H}$.

1955 Rhombodinium und Dracodinium zwei neue Dinoflagellaten-Gattungen aus dem nord-deutschen Tertiär. Neues Jahrbuch für Geologie und Paläontologie, Monatshefte 1955:84-92.

1969 Formengemeinschaften Alttertiären Mikroplank tons aus Bohrproben des Erdölfeldes Meckelfeld bei Hamburg. Palaeontographica (Abt. B) 126:1100.

GOODMAN, D. K.

1979 Dinoflagellate "communities" from the Lower Eocene Nanjemoy Formation of Maryland, U.S.A. Palynology 3:169-190.

GORKA, $\mathrm{H}$.

1963 Coccolithophorides, Dinoflagelles, Hystrichosphaerides et microfossiles incertae sedis du Crétacé supérieur de Pologne. Acta Palaeontologica Polonica 8:1-83.

HABIB, D.

1972 Dinoflagellate stratigraphy Leg 11, DSDP. In Hollister, C. D., J. E. Ewing, et al., Initial Reports of the Deep Sea Drilling Project. Washington, vol. 11, pp. 367-425.

HAECKEL, E.

1894 Entwurf eines natürlichen Systems der Organis men auf Grund ihrer Stammesgeschichte, erster Teil: Systematische Phylogenie der Protisten und Pflanzen. Berlin, G. Reiner. 400 pp.

HANSEN, J. M.

1977 Dinoflagellate stratigraphy and echinoid distribution in Upper Maastrichtian and Danian deposits from Denmark. Geological Society of Denmark, Bulletin 26:1-26.

HAO, Y. and X. ZENG

1980 The Tertiary foraminifera from Kashi area, Talimu Basin, Xinjiang Province. Acta Palaeontologica Sinica 19:152-169. (In Chinese)

1981 The Tertiary foraminifera assemblages from Kashi area, Xinjiang Province, China, and the initial discussion on the depositional environments. In Proceedings of the First Chinese Micropaleontology Conference. Publishing House of Science (China), pp. 6-13. (In Chinese)
HAO, Y., X. ZENG, and H. LI

1982 Late Cretaceous and Tertiary strata and foraminifera in Western Talimu Basin. Journal of the Wuhan College of Geology 7(2):1-161. (In Chinese)

HARKER, S. D. and W. A. S. SARJEANT

1975 The stratigraphic distribution of organic-walled dinoflagellate cysts in the Cretaceous and Tertiary. Review of Palaeobotany and Palynology 20:217315.

HARLAND, R.

1973 Dinoflagellate cysts and acritarchs from the Bearpaw Formation (Upper Campanian) of southern Alberta, Canada. Palaeontology 16:665-706.

1977 Dinoflagellate cysts from the Bearpaw Formation (? Upper Campanian to Maastrichtian) of Montana. Palaeontology 20:179-193.

1979 The Wetzeliella (Apectodinium) homomorphum plexus from the Palaeogene/earliest Eocene north west Europe. In Proceedings of the Fourth Interna tional Palynology Conference, Lucknow, 19761977, vol. 2, pp. 59-70.

HEISECKE, A. M.

1970 Microplankton de la Formacion de la Provincia de Neuquén. Ameghiniana 7:225-263.

IOANNIDES, N. S. and J. P. COLIN

1977 Palynology of Site 358, 356, 355, DSDP, Leg 39 , Southwestern Atlantic Ocean. Initial Reports of the Deep Sea Drilling Project. Washington, vol. 49, pp. 885-897.

ISLAM, M. A .

1983 Dinoflagellate cysts from the Eocene of the London and the Hampshire basins, southern England. Palynology 7:71-92.

JAIN, K. P. and P. MILLEPIED

1973 Cretaceous microplankton from Senegal Basin, N.W. Africa. 1. Some new genera, species and combinations of dinoflagellates. Palaeobotanist 20:22-32.

KJELLSTRÖM, G.

1972 Archeopyle formation in the genus Lejeunia Gerlach, 1961 emend. Geologiska Foreningens i Stock holm Forhandlingar 94:467-469.

1973 Maastrichtian microplankton from the Höllviken borehole No. 1 in Scania, southern Sweden. Sveriges Geologiska Undersoekning, Aarsbok 67, no. 8 , Ser. C, no. 688:1-59.

KLUMPP, B

1953 Beitrag zur Kenntnis der Mikrofossilien des mittleren und oberen Eozän. Palaeontographica (Abt. A) 103:377-406

LENTIN, J. K. and G. L. WILLIAMS

1973 Fossil dinoflagellates: index to genera and species. Geological Survey of Canada, Paper 73-42:1-176.

1976 A monograph of fossil peridinioid dinoflagellate cysts. Bedford Institute of Oceanography, Report BI-R-75-16:1-237.

1977 Fossil dinoflagellates: index to genera and species. Bedford Institute of Oceanography, Report BI-R 
77-8:1-209.

1981 Fossil dinoflagellates: index to genera and species. Bedford Institute of Oceanography, Report BI-R 81-12:1-345.

1985 Fossil dinoflagellates: index to genera and species. Canadian Technical Report of Hydrography and Ocean Sciences 60:1-451.

LIENGJARERN, M., L. COSTA, and C. DOWNIE

1980 Dinoflagellate cysts from the Upper EoceneLower Oligocene of the Isle of Wight. Palaeontology 23:475-499.

LOEBLICH, A. R., Jr., and A. R. LOEBLICH III

1966 Index to the genera, subgenera, and sections of the Pyrrhophyta. University of Miami, Studies in Tropical Oceanography 3:1-94.

MÄDLER, $K$.

1968 Die figurierten organischen Bestandteile der Posidonienschiefer. Geologisches Jahrbuch Beihefte 58:287-406.

MAIER, D.

1959 Planktonuntersuchungen in tertiären und quartären marinen Sedimenten. Ein Beitrag zur System atik, Stratigraphie und Ökologie der Cocco lithophorideen, Dinoflagellaten und Hystrichospharideen vom Oligozän bis zum Pleistozän. Neues Jahrbuch für Geologie und Paläontologie, Abhandlungen 107:278-340.

MANUM, S. and I. C. COOKSON

1964 Cretaceous microplankton in a sample from Graham Island, Arctic Canada, collected during the second "Fram": - Expedition (1898-1902), with notes on microplankton from the Hassel Formation, Ellef Ringnes Island. Schrifter utgitt av Det Norske Videnskaps-Akademi i Oslo, I. Matematisk-Naturvidenskapelig Klasse, Ny Series 17:1-35.

MAO, S. and G. NORRIS

1984 Dinoflagellate and acritarch stratigraphy (Late Cretaceous and Early Tertiary), western Talimu Basin, Xingjiang Autonomous Region, northwestern China. Journal of the Wuhan College of Geology 2 (Total 25):7-22. (In Chinese)

$\mathrm{MAO}, \mathrm{S}$. and J. YU

1981 In Yu, J., S. Mao, M. Sun, and S. Sun, Dinoflagellate cysts and acritarchs from Upper Cretaceous Dalanshan Formation and their significance in explaining the depositional environment. Oil and Gas Geology 2(3):225-263. (In Chinese)

MAY, F. E

1980 Dinoflagellate cysts of the Gymnodiniaceae, Peridiniaceae, and Gonyaulacaceae from the Upper Cretaceous Monmouth Group, Atlantic High lands, New Jersey. Palaeontographica (Abt. B) 172:10-116.

MCINTYRE, D. J

1974 Palynology of an Upper Cretaceous section, Hor ton River, District of Mackenzie, N.W.T., Canada. Geological Survey of Canada, Paper 74-14:1-57.

1975 Morphologic changes in Deflandrea from a Cam panian section, District of Mackenzie, N.W.T.
Canada. Geoscience and Man 11:61-76.

MENENDEZ, C. A.

1965 Microplankton fósil de sedimentos terciarios y cretacicos del norte de Tierra del Fuego (Argentina). Amenghiniana 4:7-15.

MILLIOUD, M.E.

1969 Dinoflagellates and acritarchs from some western European Lower Cretaceous type localities. In Bronnimann, P. and H. H. Renz, eds., Proceedings of the First International Conference on Plank tonic Microfossils, Geneva, 1967. Leiden, E. J. Brill, vol. 2, pp. 420-434.

MORGAN, $\mathbf{R}$.

1977 Elucidation of the Cretaceous dinoflagellate Diconodinium Eisenack and Cookson 1960 and related peridinioid species from Australia. Palynol ogy 1:123-138.

1980 Palynostratigraphy of the Australian Early and Middle Cretaceous. Memoirs of the Geological Survey of New South Wales, Palaeontology 18:1153.

MORGENROTH, $\mathrm{P}$.

1966 Mikrofossilien und Konkretionen des nordwesteuropäischen Untereozäns. Palaeontographica (Abt. B) 119:1-53

MÜLLER, J

1959 Palynology of recent Orinoco delta and shelf sediments: reports of the Orinoco Shelf Expedition. Micropalaeontology 5:1-32.

NORRIS, G.

1978 Phylogeny and a revised supra-generic classification for Triassic-Quaternary organic-walled di noflagellate cysts (Pyrrhophyta). Part II. Families and sub-orders of fossil dinoflagellates. Neues Jahrbuch für Geologie und Paläontologie Abhandlungen 156:1-30.

NORRIS, G. and R. W. HEDLUND

1972 Transapical sutures in dinoflagellate cysts. Geoscience and Man 4:49-56

NORVICK, M. S

1976 In Norvick, M. S. and D. Burger, Palynology of the Cenomanian of Bathurst Island, Northern Territory, Australia. Australian Bureau of Mineral Resources, Geology and Geophysics, Bulletin 151:21-113.

NORVICK, M. S. and D. BURGER

1976 Palynology of the Cenomanian of Bathurst Island, Northern Territory, Australia. Australian Bureau of Mineral Resources, Geology and Geophysics, Bulletin 151:21-113

PASCHER, A.

1914 Über Flagellaten und Algen. Deutsche Botanische Gesellschaft (Berlin) 32:136-160.

PHILIPPOT, A

1949 Contributions à la paléontologie des silex crétacés Trois nouveaux microfossiles. Bulletin de la Société Scientifique de Bretagne 24:55-58.

POCOCK, S. A. J.

1962 Microfloral analysis and age determination of 
strata at the Jurassic-Cretaceous boundary in the western Canada plains. Palaeontographica (Abt. B) 111:1-95.

ROSSIGNOL, $\mathrm{M}$

1964 Hystrichosphères du quarternaire en Méditerranée orientale, dans les sédiments pléistocènes et les boues marines actuelles. Revue de micropaléontologie 7:83-99.

SARJEANT, W. A. S

1960 Microplankton from the Corallian rocks of Yorkshire. Proceedings of the Yorkshire Geological Society 3:389-408.

1966 Dinoflagellate cysts with Gonyaulax-type tabulation. In Davey, R. J., C. Downie, W. A. S. Sarjeant, and G. L. Williams, Studies on Mesozoic and Cainozoic dinoflagellate cysts. Bulletin of the British Museum (Natural History) Geology, Supplement 3:107-156.

1970 The genus Spiniferites Mantell 1850 (Dinophyceae). Grana 10:74-78.

1974 Fossil and living dinoflagellates. London, Academic Press. 182 pp.

1982 Dinoflagellate cyst terminology: a discussion and proposals. Canadian Journal of Botany 60:922945.

SARJEANT, W. A. S. and C. DOWNIE

1966 The classification of dinoflagellate cysts above generic level. Grana Palynologica 6:503-527.

1974 The classification of dinoflagellate cysts above generic level: a discussion and revision. Birbal Sahni Institute of Palaeobotany, Special Publication 3:9-32.

SARJEANT, W. A. S. and L. E. STOVER

1978 Cyclonephelium and Tenua: a problem in dinoflag ellate cyst taxonomy. Grana 17:47-54.

SCULL, G. J., C. J. FELIX, S. B. MCCALEB, and W. G. SHAW

1966 The inter-discipline approach to palaeoenvironmental interpretations. Transactions of the Gulf Coast Association of Geological Societies 16:81117.

SINGH, C.

1964 Microflora of the Lower Cretaceous Mannville Group, east-central Alberta. Research Council of Alberta, Bulletin 15:1-239.

1971 Lower Cretaceous microfloras of the Peace River area, north-western Alberta. Research Council of Alberta, Bulletin 28:301-542.

SMITH, A. G. and J.C. BRIDEN

1977 Mesozoic and Cenozoic paleocontinental maps. Cambridge Earth Science Series. Cambridge, Cam bridge University Press. $63 \mathrm{pp}$.

STANLEY, E. A.

1965 Upper Cretaceous and Paleocene plant microfossils and Paleocene dinoflagellates and hystrichosphaerids from north-western South Dakota. Bulletins of American Paleontology 49:179-384.

STAPLIN, F. L.

1961 Reef-controlled distribution of Devonian microplankton in Alberta. Palaeontology 4:392-424.
STEIN, F. R. von

1883 Der Organismus der Infusionsthiere nach einigen Forschungen in systematischer Reihenfolge bearbeitet. Abt. III, Hälfte II, Die Naturgeschichte der arthrodelen Flagellaten. Leipzig, Wilhelm Engelmenn. $30 \mathrm{pp}$.

STOVER, L. E. and W. R. EVITT

1978 Analyses of pre-Pleistocene organic-walled dino flagellates. Stanford University Publications, Geological Sciences 15:1-300.

SUNG, Z., C. HE, Z. PAN, Z. QIAN, G. ZHENG, and Y. ZHENG

1978 On the Palaeogene dinoflagellates and acritarchs from the coastal region of Bohai, China. Publishing House of Science (China). 190 pp. (In Chinese)

TASCH, $\mathbf{P}$

1964 In Tasch, P., K. McClure, and O. Oftedahl, Bio stratigraphy and taxonomy of a hystrichospheredinoflagellate assemblage from the Cretaceous of Kansas. Micropaleontology 10:189-206.

VALENSI, $L$.

1947 Note préliminaire à une étude des microfossiles des silex jurassiques de la région de Poitiers. Compte rendu de l'Académie des Sciences, Paris, 225:816818.

1953 Microfossiles des silex Jurassique moyen. Remarques pétrographiques. Mémoire de la Société Géologique de France 68:1-100.

VOZZHENNIKOVA, T. F.

1963 Pirrofitovye Vodorosli. [Phylum Pyrrophyta.] In Orlov, Yu. A., ed., Osnovy Paleontologii [Funda mentals of Paleontologyl 14:179-185.

1965 Vvedenie $\mathrm{v}$ izuchenie iskopaemyki peridineevykh vodorosli. [Introduction to the study of fossil peridinian algae.] Akademiya Nauk SSSR, Sibirskoye Otdeleniye, Institut Geologii i Geofiziki, Trudy. $156 \mathrm{pp}$.

1967 Iskopayemyye peridinei yurskikh, melovykh i paleogenovykh otlozheniy SSSR. [Fossil peridinians of the Jurassic, Cretaceous and Paleogene deposit of the USSR.] Akademiya Nauk SSSR, Sibirskoye Otdeleniye, Institut Geologii i Geofiziki, Trudy. $347 \mathrm{pp}$.

WALL, D.

1967 Fossil microplankton in deep-sea cores from the Caribbean Sea. Palaeontology 10:95-123.

WALL, D. and B. DALE

1968 Modern dinoflagellate cysts and evolution of the Peridiniales. Micropaleontology 14:265-304.

1973 In Wall, B., B. Dale, and K. Harada, Descriptions of new fossil dinoflagellates from the Late Quaternary of the Black Sea. Micropaleontology 19:1831.

WANG, H., B. LIU, S. LIU, S. LI, L. WANG, R. WU, X. ZHAO, and Z. ZHOU

1980 A course of study in historical geology. Beijing, Geological Publishing House (China). 352 pp. (In Chinese)

WEILER, $\mathrm{H}$.

1956 Über einen Fund von Dinoflagellaten, Coccolithophoriden und Hystrichosphaeriden im Tertiär 
des Rheintales. Neues Jahrbuch für Geologie und Paläontologie, Monatshefte 104:129-147.

WETZEL, 0

1933a Die in organischer Substanz erhaltenen Mikrofossilien des baltischen Kreide-Feuersteins mit einem sediment-petrographischen und stratigraphischen Anhang. Palaeontographica (Abt. A) 77:141-188.

1933b Die in organischer Substanz erhaltenen Mikrofossilien des baltischen Kreide-Feuersteins mit einem sediment-petrographischen und stratigraphischen Anhang. Palaeontographica. (Abt. A) 78:1-110.

WHITE, H. H.

1842 On fossil Xanthidia. Microscopic Journal 11:3540 .

WHITNEY, B. L.

1979 A population study of Alterbia acutula (Wilson) Lentin and Williams from the Maestrichtian (Upper Cretaceous) of Maryland. Palynology 3:123-128.

WILLIAMS, G. L.

1975 Dinoflagellates and spore stratigraphy of the Mesozoic-Cenozoic offshore Eastern Canada. Geological Survey of Canada Paper 74-30, 2:107-161.

WILLIAMS, G. L. and W. W. BRIDEAUX

1975 Palynological analyses of Upper Mesozoic and Cenozoic rocks of the Grand Banks, Atlantic continental margin. Geological Survey of Canada, Bulletin 236:1-162.

WILLIAMS, G. L. and C. DOWNIE

1966a Further dinoflagellate cysts from the London Clay. In Davey, R. J., C. Downie, W. A. S. Sarjeant, and G. L. Williams, Studies on Mesozoic and Cainozoic dinoflagellate cysts. Bulletin of the British Museum (Natural History) Geology, Supplement 3:215235.

1966b The genus Hystrichokolpoma. In Davey, R. J., C. Downie, W. A. S. Sarjeant, and G. L. Williams, Studies on Mesozoic and Cainozoic dinoflagellate cysts. Bulletin of the British Museum (Natural History) Geology, Supplement 3:176-181.

1966c Wetzeliella from the London Clay. In Davey, R. J., C. Downie, W. A. S. Sarjeant, and G. L. Williams, Studies on Mesozoic and Cainozoic dinoflagellate cysts. Bulletin of the British Museum (Natural History) Geology, Supplement 3:182-198.

WILSON, G. J.

1967a Some new species of Lower Tertiary dinoflagellates from McMurdo Sound, Antarctica. New Zealand
Journal of Botany 5:57-83.

1967b Microplankton from the Garden Cove Formation, Campbell Island. New Zealand Journal of Botany 5:223-240.

1971 Observation on European Late Cretaceous dino flagellate cysts. In Farinacci, A., ed., Proceedings of the Second Plankton Conference, Rome, 1970. Rome, Edizioni Technoscienza, vol. 2, pp. 1259 1276.

WILSON, G. J. and C. D. CLOWES

1980 A concise catalogue of organic-walled fossil dino flagellate genera. New Zealand Geological Survey, Report 92:1-199.

WISEMAN, J. F. and A. J. WILLIAMS

1974 Palynological investigation of samples from Sites 259, 261 and 263, Leg 27, DSDP. Initial Reports of the Deep Sea Drilling Project. Washington, vol. 27 , pp. 915-924.

YANG, Z., Y. CHENG, and H. WANG

1986 The geology of China. Oxford Monographs on Geology and Geophysics 3. Oxford, Clarendon Press.

YU, J

1981 Late Cretaceous sporo-pollen assemblages of Shache District, Xinjiang. Acta Geologica Sinica 29:93-102.

YU, J., and W. ZHANG

1980 Upper Cretaceous dinoflagellate cysts and acritarchs of Western Xinjiang. Bulletin of Chinese Academy of Geological Sciences 2, series 1:93119. (In Chinese)

YU, J., S. MAO, M. SUN, and S. SUN

1981 Dinoflagellate cysts and acritarchs from Upper Cretaceous Dalanshan Formation and their significance in explaining the depositional environment. Oil and Gas Geology 2(3):225-263. (In Chinese)

YUN, H.S

1981 Dinoflagellaten aus der Oberkrede (Santon) von Westfalen. Palaeontographica (Abt. B) 177:1-89

ZHANG, Z. M., J. G. LIOU, and R. G. COLEMAN

1984 An outline of the plate tectonics of China. Geological Society of America, Bulletin 95:295-312.

ZHAO, Y., X. SUN, and D. WANG

1981 Tertiary sporo-pollen assemblages from Shache and Kuche basins, Xinjiang. Bulletin of the Institute of Geological Research, Chinese Academy of Geolog ical Sciences 4:97-126. 
Plate 1, figs. 1-23.

All figures $\times 500$.

1. Canningia colliveri Cookson and Eisenack, Kukebai Formation $\left(\mathrm{K}_{2} \mathrm{k}\right)$. Specimen showing operculum attached. WG- $14 ; \mathrm{A}_{3} ; 39.4 / 99.7$.

2. Canningia (?) minor Cookson and Hughes, Kukebai Formation $\left(\mathrm{K}_{2} \mathrm{k}\right)$, WG-18; $\mathrm{A}_{2} ; 38.4 / 101.4$.

Figs. 3-5. Canningia reticulata Cookson and Eisenack.

3. Specimen showing operculum attached. Wuyitake Formation $\left(\mathrm{K}_{2} \mathrm{~W}\right)$, WG-31; $\mathrm{A}_{1} ; 48.9 / 111.3$.

4. Specimen showing cingulum and detached operculum. Kukebai Formation $\left(\mathrm{K}_{2} \mathrm{k}\right), \mathrm{WG}-20 ; \mathrm{A}_{4}$; 45.7/102.5.

5. Specimen showing operculum detached. Wuyitake Formation $\left(\mathrm{K}_{2} \mathrm{~W}\right), \mathrm{WG}-31 ; \mathrm{A}_{1} ; 43.2 / 107.8$.

Figs. 6-8. Canningia kukebaiensis sp. nov., Kukebai Formation $\left(\mathrm{K}_{2} \mathrm{k}\right)$.

6. Paratype, WG-20; $\mathrm{A}_{1} ; 47.0 / 99.2$.

7. Holotype, WG-20; $\mathrm{A}_{4} ; 45.1 / 101.3$.

8. WG-20; $A_{1} ; 49.7 / 96.7$. Apical view.

Figs. 9,10. Cerbia formosa sp. nov., Wulagen Formation $\left(\mathrm{E}_{2} \mathrm{w}\right)$.

9. Holotype, QF-82; $\mathrm{A}_{4} ; 39.3 / 104.6$. Ventral view, sulcus delineated by lack of processes.

10. Paratype, QF-82; $\mathrm{A}_{4} ; 38.2 / 100.3$. Dorsal view, cingulum indicated faintly by the alignment of processes.

11. Odontochitina costata Alberti, Kukebai Formation $\left(\mathrm{K}_{2} \mathrm{k}\right)$, WG-14; $\mathrm{A}_{1} ; 41.4 / 105.3$.

Figs. 12,13. Odontochitina operculata (O. Wetzel) Deflandre and Cookson, Kukebai Formation $\left(\mathrm{K}_{2} \mathrm{k}\right)$.

12. Operculum, WG-16; $\mathrm{A}_{6} ; 28.2 / 111.2$.

13. Specimen with detached operculum, WG-16; $\mathrm{A}_{6} ; 44.1 / 103.4$.

14. Odontochitina porifera Cookson, Kukebai Formation $\left(\mathrm{K}_{2} \mathrm{k}\right)$, WG-20; $\mathrm{A}_{4} ; 41.2 / 103.2$.

15. Odontochitinopsis molesta (Deflandre) Eisenack, Kukebai Formation $\left(K_{2} \mathrm{k}\right)$, WG-14; $\mathrm{A}_{3} ; 39.5 / 105.5$. Specimen showing the attached operculum.

Figs. 16-18. Cyclonephelium brevispinatum (Millioud) Below, Kukebai Formation $\left(\mathrm{K}_{2} \mathrm{k}\right)$.

16. WG-13; $\mathrm{A}_{3} ; 55.8 / 107.2$.

17. WG-14; $\mathrm{A}_{1} ; 30.8 / 100.2$.

18. WG-13; $\mathrm{A}_{6} ; 23.9 / 108.7$.

19. Cyclonephelium compactum Deflandre and Cookson, Wulagen Formation $\left(\mathrm{E}_{2} \mathrm{~W}\right), \mathrm{WG}-63 ; \mathrm{A}_{2}$; $38.8 / 102.4$.

20. Cyclonephelium distinctum Deflandre and Cookson, Kukebai Formation $\left(\mathrm{K}_{2} \mathrm{k}\right)$, WG-20; $\mathbf{A}_{1}$; $37.3 / 109.2$

Figs. 21,22. Cyclonephelium (?) hystrix (Eisenack) Davey.

21. Wuyitake Formation $\left(\mathrm{K}_{2} \mathrm{~W}\right), \mathrm{WG}-31 ; \mathrm{A}_{2} ; 51.5 / 98.5$.

22. Kukebai Formation $\left(\mathrm{K}_{2} \mathrm{k}\right)$, WG-20; $\mathrm{A}_{4} ; 50.8 / 98.8$.

23. Cyclonephelium paucispinum Davey, Wulagen Formation $\left(\mathrm{E}_{2} \mathrm{~W}\right), \mathrm{QF}-86 ; \mathrm{A}_{5} ; 44.1 / 100.5$. 

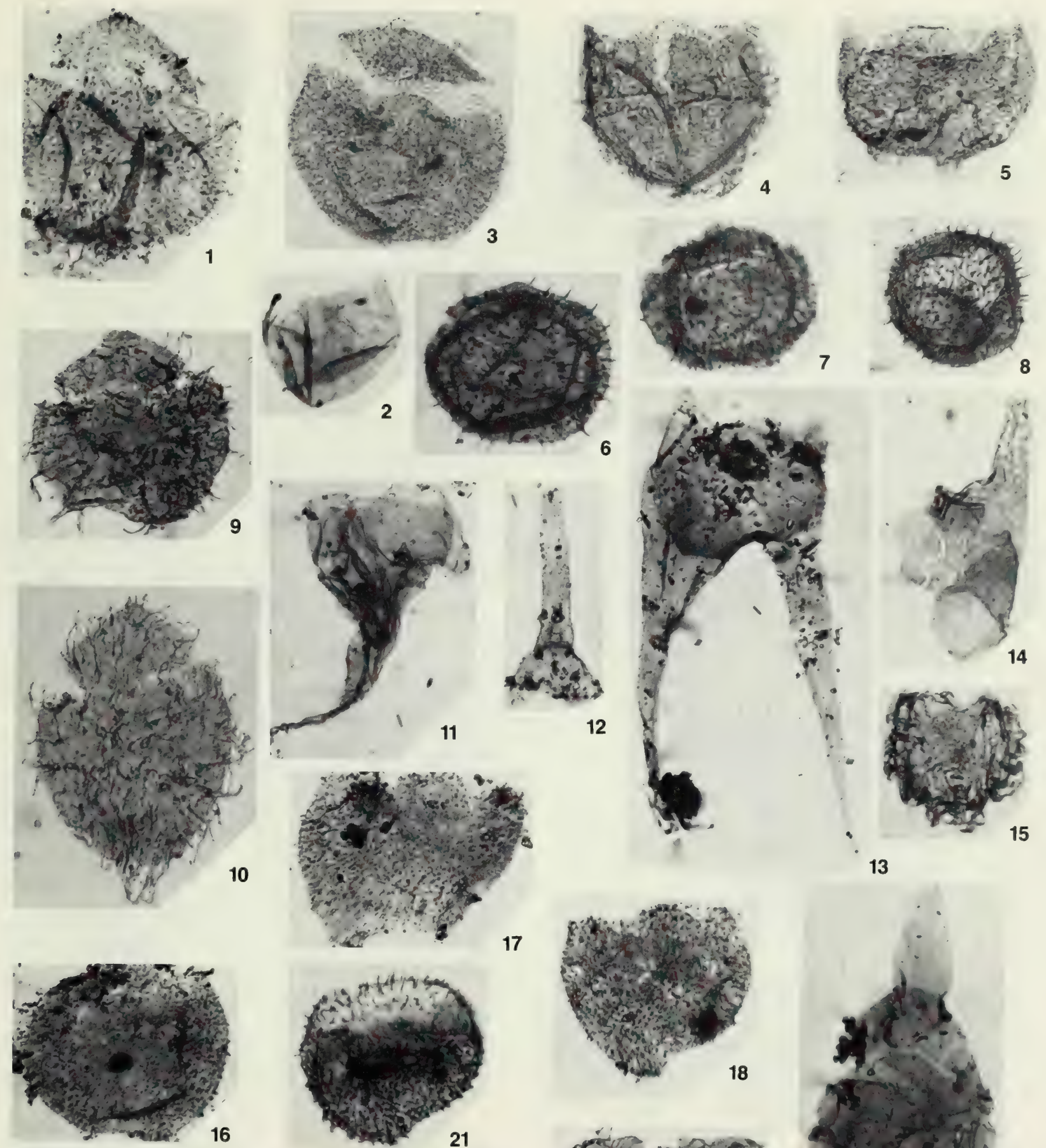
Plate 2, figs. $1-19$.

All figures $\times 500$.

1. Cyclonephelium vannophorum Davey, Kukebai Formation $\left(\mathrm{K}_{2} \mathrm{k}\right)$, WG-20; $\mathrm{A}_{4} ; 46.2 / 97.6$.

Figs. 2,3. Glaphyrocysta exuberans (Deflandre and Cookson), Stover and Evitt, Qimugen Formation (E $\left.E_{1} q\right)$.

2. QF-43; $\mathrm{A}_{2} ; 40.3 / 96.0$.

3. QF-43; $\mathrm{A}_{4} ; 34.6 / 101.0$.

4. Glaphyrocysta intricata (Eaton) Stover and Evitt, Wulagen Formation, ( $\left.\mathrm{E}_{2} \mathrm{~W}\right)$, WG-63; $\mathrm{A}_{3} ; 37.4 / 99.3$.

5. Glaphyrocysta laciniiformis (Gerlach) Stover and Evitt, Wulagen Formation $\left(\mathrm{E}_{2} \mathbf{W}\right), \mathrm{QF}-82 ; \mathrm{A}_{4}$; $51.0 / 102.3$.

6. Glaphyrocysta ordinata (Williams and Downie) Stover and Evitt, Wulagen Formation ( $\left.\mathrm{E}_{2} \mathrm{~W}\right), \mathrm{QF}-82$; $\mathrm{A}_{4} ; 45.4 / 99.8$.

Figs. 7,8 Glaphyrocysta pastielsii (Deflandre and Cookson) Stover and Evitt, Wulagen Formation $\left(\mathrm{E}_{2} \mathrm{w}\right)$. 7. QF-86; $\mathrm{A}_{1} ; 47.3 / 104.7$.

8. QF-86; $\mathrm{A}_{5} ; 43.7 / 106.7$.

Figs. 9-13. Membranophoridium aspinatum Gerlach, Wulagen Formation $\left(\mathrm{E}_{2} \mathrm{~W}\right)$.

9. QF-86; $\mathrm{A}_{2} ; 50.2 / 111.5$.

10. QF-86; $\mathrm{A}_{1} ; 42.3 / 98.5$.

11. QF-86; $\mathrm{A}_{2} ; 43.9 / 100.0$. Specimen bearing a few isolated processes.

12. QF-86; $\mathrm{A}_{5} ; 50.3 / 97.5$.

13. QF-86; $\mathrm{A}_{4} ; 42.6 / 108.0$.

Figs. 14-16. Gonyaulacysta sp., Wulagen Formation $\left(\mathrm{E}_{2} \mathrm{~W}\right)$.

14. QF-82; $\mathrm{A}_{1} ; 52.6 / 100.0$.

15,16. QF-86; $\mathrm{A}_{4} ; 39.2 / 99.3$. High focus (dorsal) and low focus (ventral) respectively.

Figs. 17-19. Millioudodinium (?) aequum sp. nov., Kukebai Formation $\left(\mathrm{K}_{2} \mathrm{k}\right)$.

17. Holotype, WG-14; $\mathrm{A}_{3} ; 41.5 / 101.9$. Dorsal view.

18. WG-14; $A_{1} ; 44.3 / 100.0$. Dorsal view.

19. Paratype, WG-14; $A_{2} ; 41.1 / 98.3$. Attached operculum (plate $3^{\prime \prime}$ ) in lateral position. 

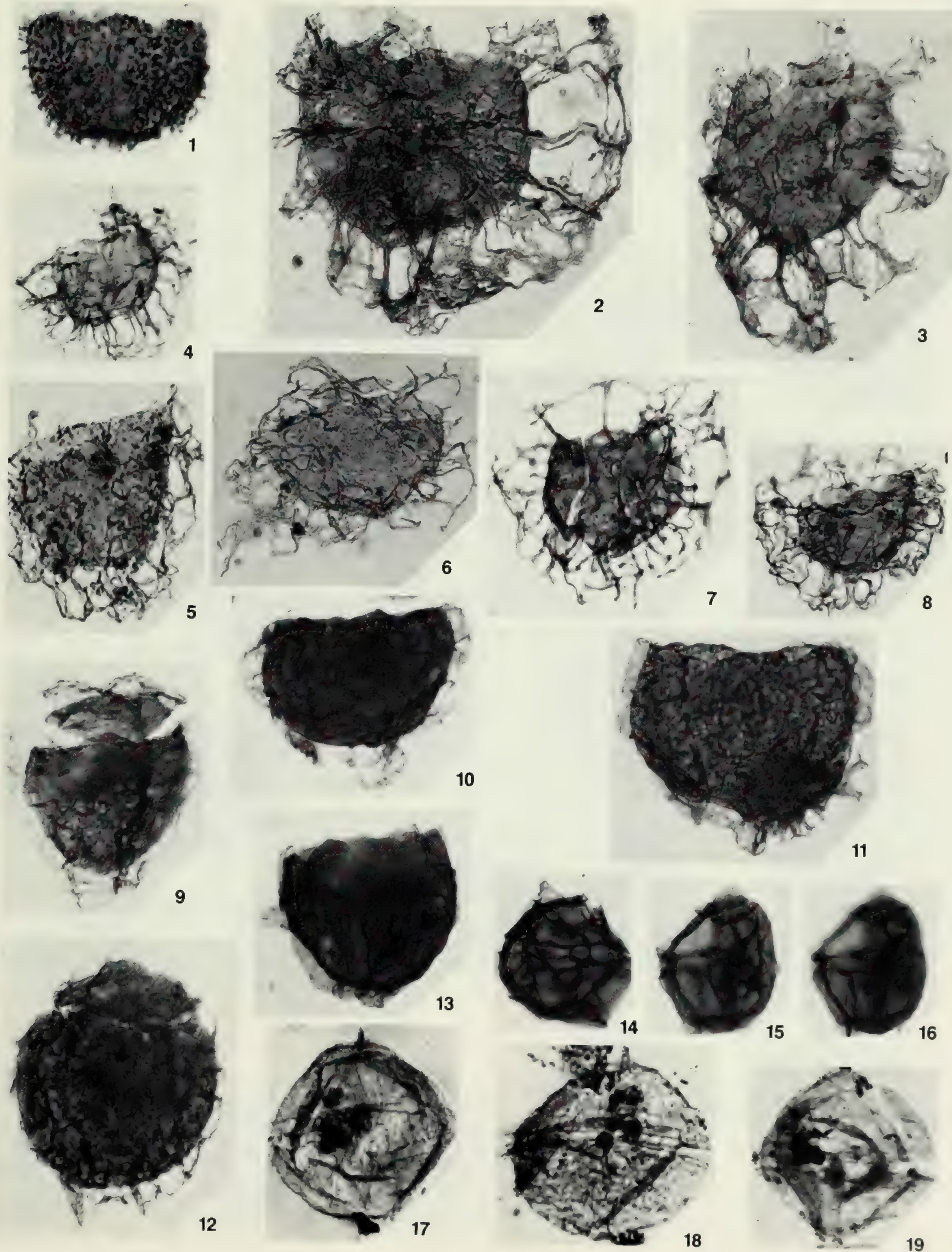
Plate 3, figs. 1-29.

All figures $\times 500$.

Figs. 1,2. Millioudodinium (?) venulosum $\mathrm{sp}$. nov., Kukebai Formation $\left(\mathrm{K}_{2} \mathrm{k}\right)$.

1. Holotype, WG-14; $A_{1} ; 40.4 / 105.5$. Specimen in lateral view showing operculum (plate $3^{\prime \prime}$ ) attached.

2. WG- $14 ; A_{1} ; 40.5 / 101.8$.

3. Millioudodinium sp., Wuyitake Formation $\left(\mathrm{K}_{2} \mathrm{~W}\right)$, WG-31; $\mathrm{A}_{10} ; 44.5 / 95.3$.

4. Pterodinium cingulatum (O. Wetzel) Below, Kukebai Formation ( $\left.\mathrm{K}_{2} \mathrm{k}\right), \mathrm{WG}-20 ; \mathrm{A}_{4} ; 41.2 / 99.0$.

5. Apteodinium conjunctum Eisenack and Cookson, Wuyitake Formation $\left(\mathrm{K}_{2} \mathrm{~W}\right)$, WG-31; $\mathrm{A}_{2}$; 23.0/101.5.

6. Apteodinium maculatum Eisenack and Cookson, Wuyitake Formation $\left(\mathrm{K}_{2} \mathrm{~W}\right)$, WG-31; $\mathrm{A}_{2} ; 4$ 1.3/97.9.

7. Chytroeisphaeridiea sp., Kukebai Formation $\left(\mathrm{K}_{2} \mathrm{k}\right)$, WG-18; $\mathrm{A}_{2} ; 48.3 / 104.2$. Specimen showing microreticulate autophragm and precingular archeopyle.

8. Kenleyia sp., Wulagen Formation $\left(\mathrm{E}_{2} \mathrm{~W}\right), \mathrm{QF}-86 ; \mathrm{A}_{5} ; 46.2 / 108.4$

9. Tectatodinium sp. cf. T. pellitum Wall, Wulagen Formation ( $\left.\mathrm{E}_{2} \mathrm{~W}\right), \mathrm{QF}-82 ; \mathrm{A}_{1} ; 49.4 / 95.9$.

10. Achomosphaera crassipellis (Deflandre and Cookson) Stover and Evitt, Qimugen Formation ( $\left.\mathrm{E}_{1} \mathrm{q}\right)$, QF-43; $\mathrm{A}_{2} ; 45.4 / 106.0$.

11. Achomosphaera mariannae Philippot, Qimugen Formation ( $\left.E_{1} q\right)$, QF-43; $A_{2} ; 40.8 / 109.3$.

Figs. 12,13. Achomosphaera ramulifera (Deflandre) Evitt.

12. Qimugen Formation ( $\left.\mathrm{E}_{1} \mathrm{q}\right)$, QF-43; $\mathrm{A}_{2} ; 42.1 / 102.3$.

13. Wulagen Formation $\left(\mathrm{E}_{2} \mathrm{~W}\right), \mathrm{QF}-86 ; \mathrm{A}_{5} ; 48.6 / 103.0$.

14. Spiniferites supparus (Drugg) Sarjeant, Wulagen Formation ( $E_{2}$ w), WG-63; $A_{1} ; 28.5 / 103.6$.

Figs. 15,16. Spiniferites cornutus (Gerlach) Sarjeant, Wulagen Formation $\left(\mathrm{E}_{2} \mathrm{w}\right)$.

15. WG-63; $\mathrm{A}_{1} ; 35.8 / 101.6$.

16. QF-86; $A_{5} ; 48.9 / 97.7$.

17. Spiniferites cornutus subsp. normalis (Cookson and Eisenack) Lentin and Williams, Qimugen Formation ( $\left.\mathrm{E}_{1} \mathrm{q}\right)$, QF-43; $\mathrm{A}_{3} ; 49.7 / 99.6$.

18. Spiniferites katatonos Corradini, Kukebai Formation $\left(\mathrm{K}_{2} \mathrm{k}\right)$, WG-13; $\mathrm{A}_{1} ; 36.7 / 99.0$.

19. Spiniferites ramosus subsp. ramosus (Ehrenberg) Loeblich and Loeblich, Kukebai Formation $\left(\mathrm{K}_{2} \mathrm{k}\right)$, WG-20; A4; 47.8/100.8.

20. Spiniferites ramosus subsp. granosus (Davey and Williams) Lentin and Williams, Qimugen Formation ( $\left.\mathrm{E}_{1} \mathrm{q}\right), \mathrm{QF}-43 ; \mathrm{A}_{2} ; 40.5 / 103.2$

Figs. 21-26. Spiniferites ramosus subsp. multibrevis (Davey and Williams) Lentin and Williams.

21. Wulagen Formation $\left(\mathrm{E}_{2} \mathrm{~W}\right), \mathrm{QF}-86 ; \mathrm{A}_{5} ; 45.5 / 96.5$.

22. Wulagen Formation $\left(\mathrm{E}_{2} \mathrm{~W}\right), \mathrm{QF}-86 ; \mathrm{A}_{5} ; 50.3 / 90.8$

23. Bashibulake Formation ( $\left.\mathrm{E}_{3} \mathrm{~b}\right)$, WG-70; $\mathrm{A}_{7} ; 35.2 / 98.2$

24. Kukebai Formation $\left(\mathrm{K}_{2} \mathrm{k}\right)$, WG-20; $\mathrm{A}_{4} ; 49.7 / 96.7$.

25. Qimugen Formation ( $\left.\mathrm{E}_{1} \mathrm{q}\right), \mathrm{QF}-43 ; \mathrm{A}_{4} ; 16.8 / 110.1$.

26. Kukebai Formation $\left(\mathrm{K}_{2} \mathrm{k}\right)$, WG-20; $\mathrm{A}_{4} ; 49.7 / 96.7$.

27. Spiniferites ramosus subsp. multiplicatus (Rossignol) Lentin and Williams, Bashibulake Formation (E $\left.\mathrm{E}_{3} \mathrm{~b}\right), \mathrm{QF}-94 ; \mathrm{A}_{1} ; 51.9 / 100.2$.

Figs. 28,29. Samlandia chlamydophora Eisenack, Bashibulake Formation $\left(\mathrm{E}_{3} \mathrm{~b}\right)$.

28. QF-94; $\mathrm{A}_{1} ; 47.4 / 110.2$.

29. Different focus of the same specimen. 

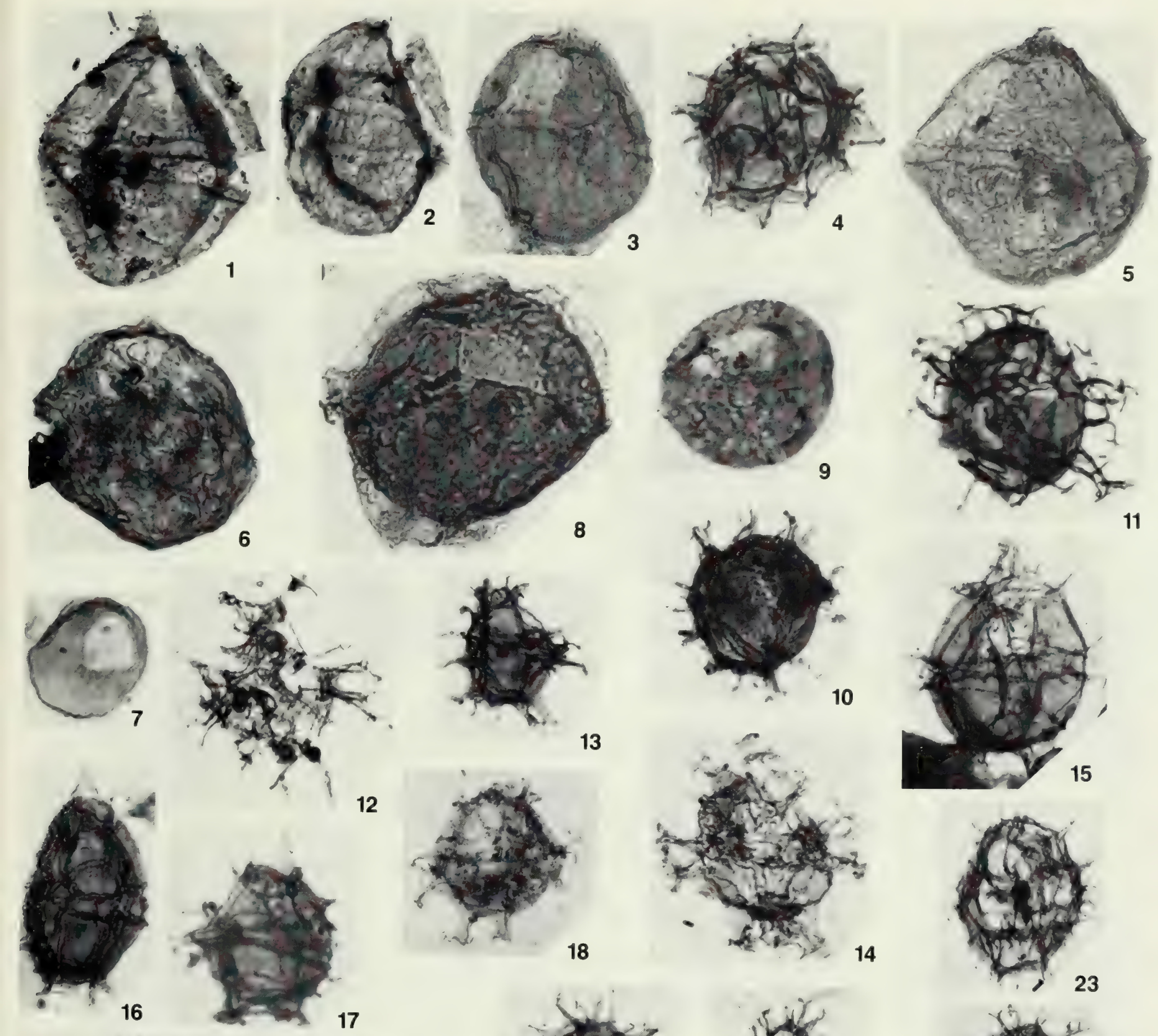

13
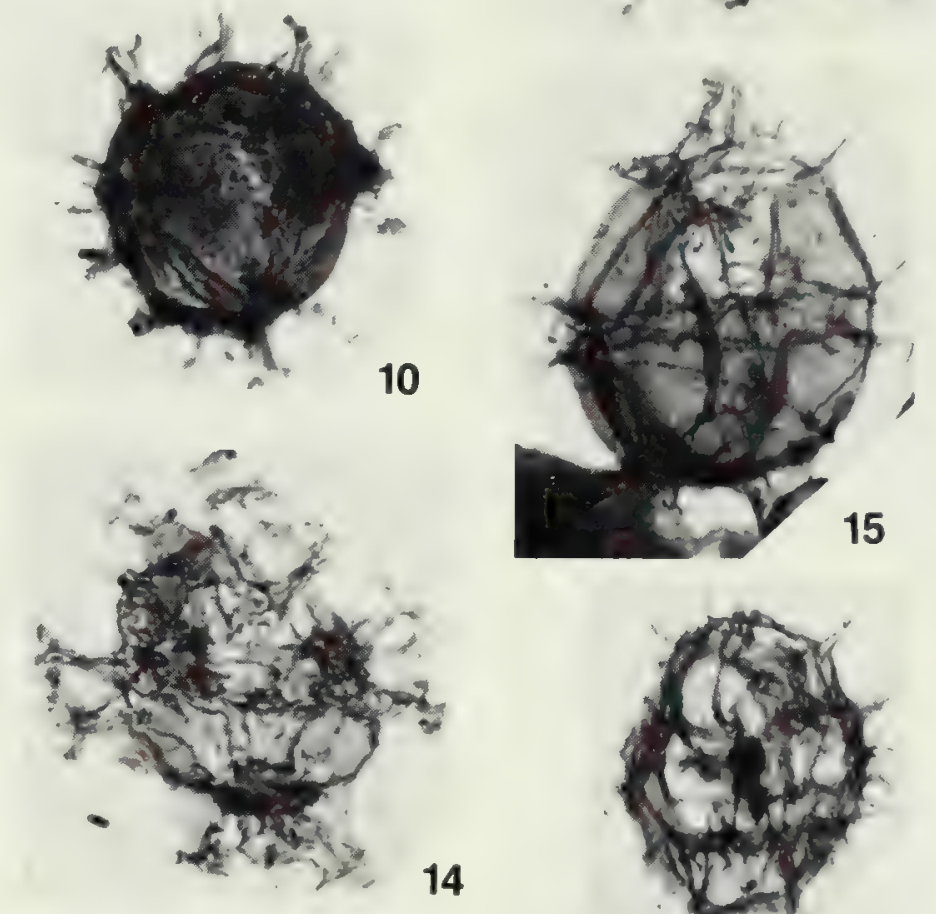

11
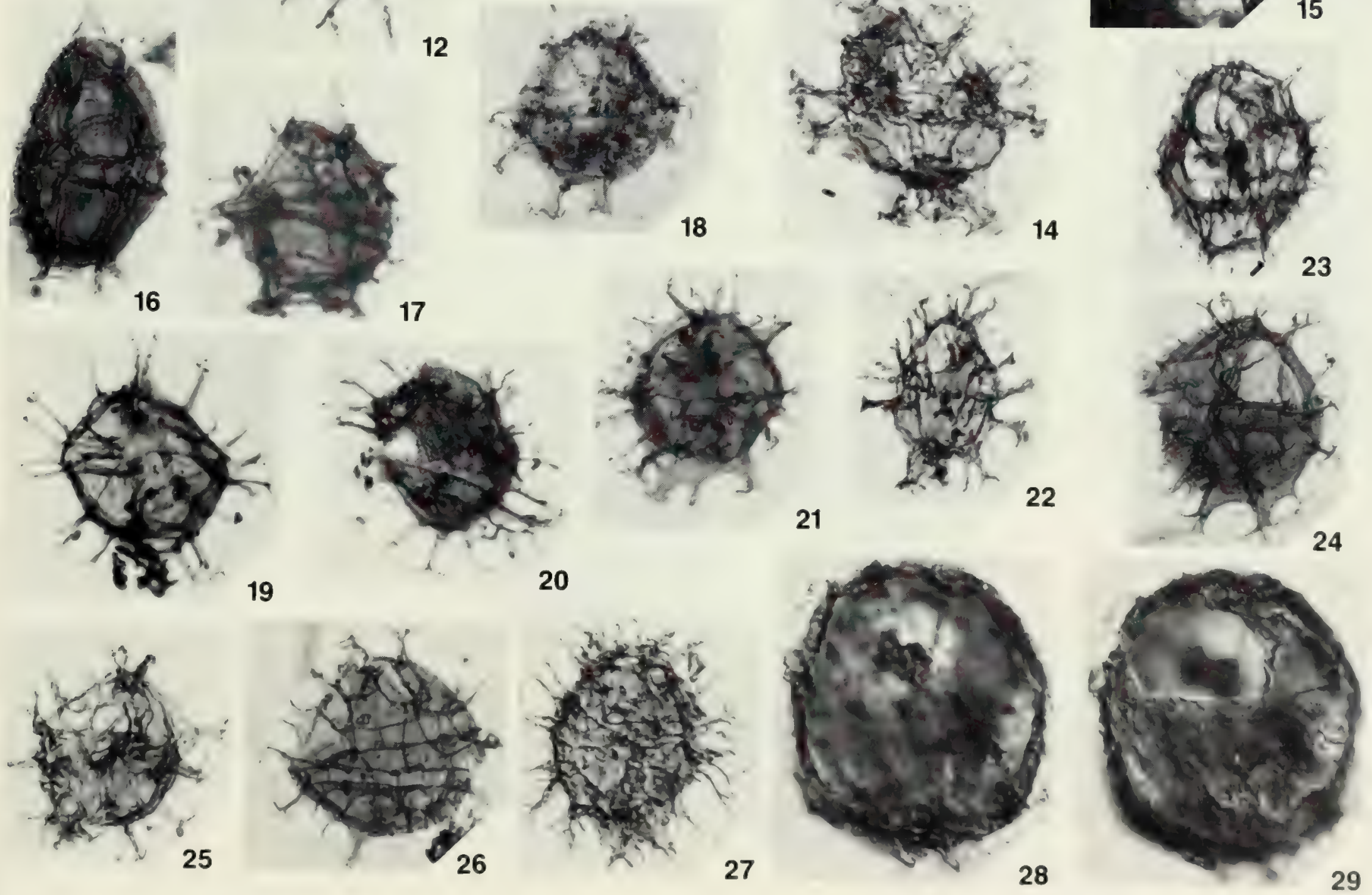
Plate 4, figs. 1-24.

All figures $\times 500$ unless otherwise stated.

Figs. 1,2. Achilleodinium biformoides (Eisenack) Eaton, Wulagen Formation $\left(\mathrm{E}_{2} \mathrm{w}\right)$.

1. QF-86; $\mathrm{A}_{2} ; 49.4 / 105.2$.

2. WG-63; $\mathrm{A}_{2} ; 33.7 / 102.5$.

Figs. 3,4. Achilleodinium latispinosum (Davey and Williams) Bujak et al., Wulagen Formation $\left(\mathrm{E}_{2} \mathrm{w}\right)$.

3. QF-86; As; 54.1/104.8.

4. Different focus of the same specimen.

5. Araneosphaera araneosa Eaton, Qimugen Formation $\left(\mathrm{E}_{1} \mathrm{q}\right), \mathrm{QF}-43 ; \mathrm{A}_{2} ; 46.3 / 98.7$.

6. Bacchidinium polypes subsp. clavulum (Davey) Lentin and Williams, Kukebai Formation $\left(\mathrm{K}_{2} \mathrm{k}\right)$, WG-20; A4; 44.3/104.6 ( × 700).

7. Cordosphaeridium biarmatum Morgenroth, Wulagen Formation ( $\left.\mathrm{E}_{2} \mathrm{~W}\right)$, WG-63; $\mathrm{A}_{5} ; 38.9 / 106.5$.

Figs. 8,9. Cordosphaeridium exilimurum Davey and Williams, Wulagen Formation $\left(\mathrm{E}_{2} \mathrm{~W}\right)$.

8. QF-86; As; 50.5/97.9.

9. WG-63; $\mathrm{A}_{2} ; 41.3 / 104.2$.

10. Cordosphaeridium funiculatum Morgenroth, Bashibulake Formation ( $\left.\mathrm{E}_{3} \mathrm{~b}\right)$, WG-72; $\mathrm{A}_{2} ; 31.0 / 100.0$. Cyst fragment showing the distinct surface and two processes.

Figs. 11,12. Cordosphaeridium inodes subsp. longipes Hansen, Wulagen Formation $\left(\mathrm{E}_{2} \mathrm{~W}\right)$.

11. QF-86; $\mathrm{A}_{2} ; 40.0 / 108.8$.

12. QF-86; $\mathrm{A}_{2} ; 41.9 / 103.7$.

Figs. 13-15. Melitasphaeridium asterium (Eaton) Bujak et al., Wulagen Formation $\left(\mathrm{E}_{2} \mathrm{w}\right)$.

13. QF-82; $\mathrm{A}_{4} ; 40.0 / 104.3$.

14. QF-86; $\mathrm{A}_{3} ; 53.5 / 110.6$.

15. QF-82; $\mathrm{A}_{1} ; 42.6 / 103.1$.

16. Turbiosphaera filosa (Wilson) Archangelsky, Wulagen Formation ( $\left.\mathrm{E}_{2} \mathrm{~W}\right)$, WG-63; $\mathrm{A}_{5} ; 39.9 / 95.3$.

17. Turbiosphaera galatea Eaton, Bashibulake Formation $\left(\mathrm{E}_{3} \mathrm{~b}\right)$, WG-72; $\mathrm{A}_{2} ; 36.2 / 102.3$.

Figs. 18-22. Coronifera minor (Yu and Zhang) comb. nov., Kukebai Formation $\left(\mathrm{K}_{2} \mathrm{k}\right)$.

18. WG-20; $\mathrm{A}_{4} ; 39.9 / 101.0$. Specimen showing the combination archeopyle formed by the loss of plate $\mathrm{tA}+\mathrm{P}\left(3^{\prime \prime}\right)$.

19. WG-18; $\mathrm{A}_{2} ; 49.0 / 96.8$. Specimen showing the precingular archeopyle formed by the loss of the plate $3^{\prime \prime}$.

20. WG-20; $\mathrm{A}_{4} ; 41.7 / 99.9$. Specimen showing the combination archeopyle formed by the loss of plate $3 "$ and dislodged apical plates.

21. WG-20; $\mathrm{A}_{4} ; 47.6 / 105.7$.

22. WG-20; $\mathrm{A}_{4} ; 42.0 / 104.5$. Two specimens showing the combination archeopyle formed by the loss of apical plates, and the attached precingular plate $3^{\prime \prime}$.

23. Coronifera striolata (Deflandre) Stover and Evitt, Bashibulake Formation $\left(\mathrm{E}_{3} \mathrm{~b}\right)$, WG-70; $\mathrm{A}_{2}$; $50.0 / 110.0$. Specimen showing the combination archeopyle formed by the dislodged apical plates (tA) and free of precingular plate $\left(3^{\prime \prime}\right)$.

24. Coronifera sp., Qimugen Formation ( $\left.\mathrm{E}_{1} \mathrm{q}\right), \mathrm{QF}-43 ; \mathrm{A}_{2} ; 39.8 / 104.1$. 

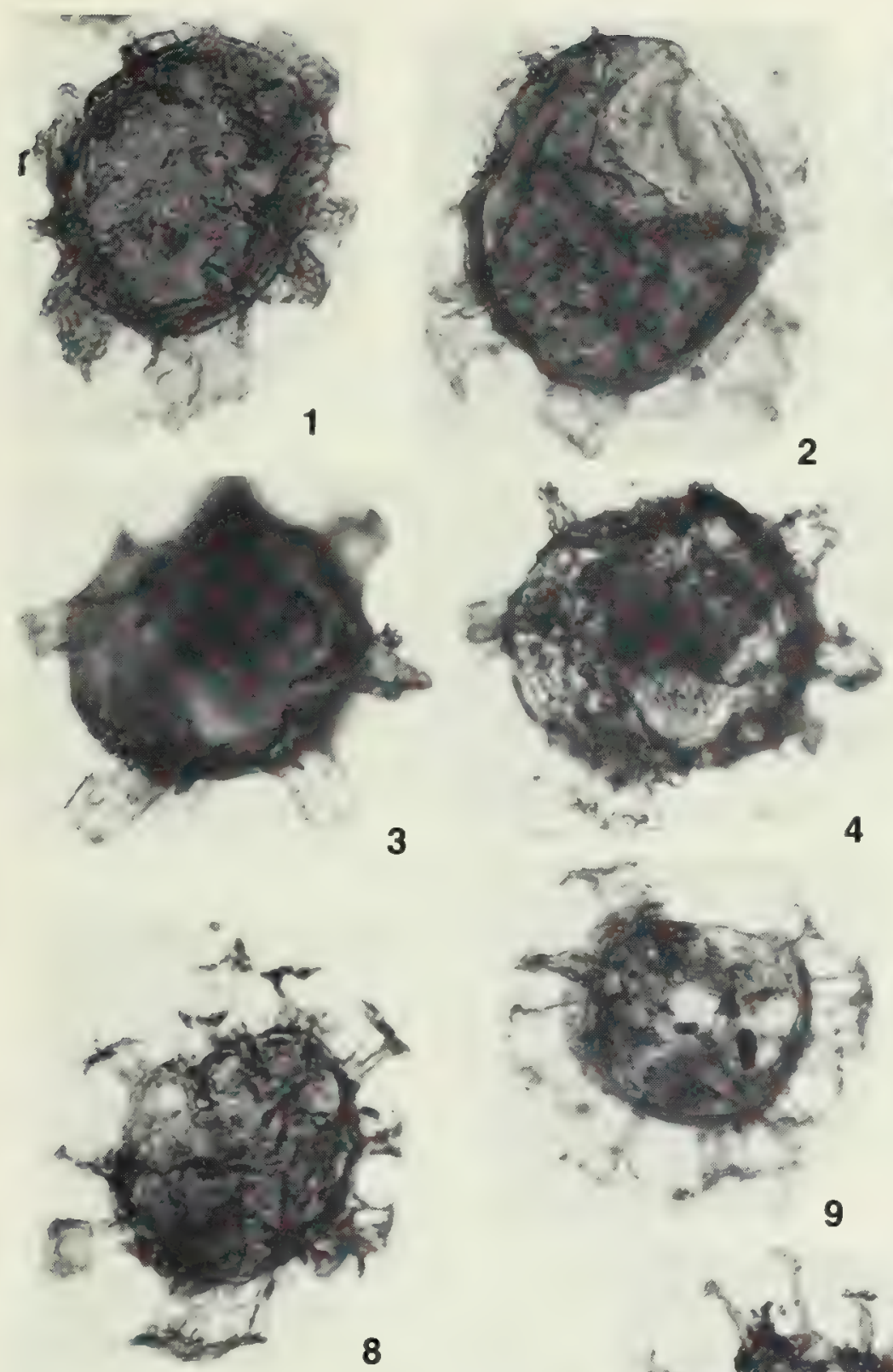

4

.
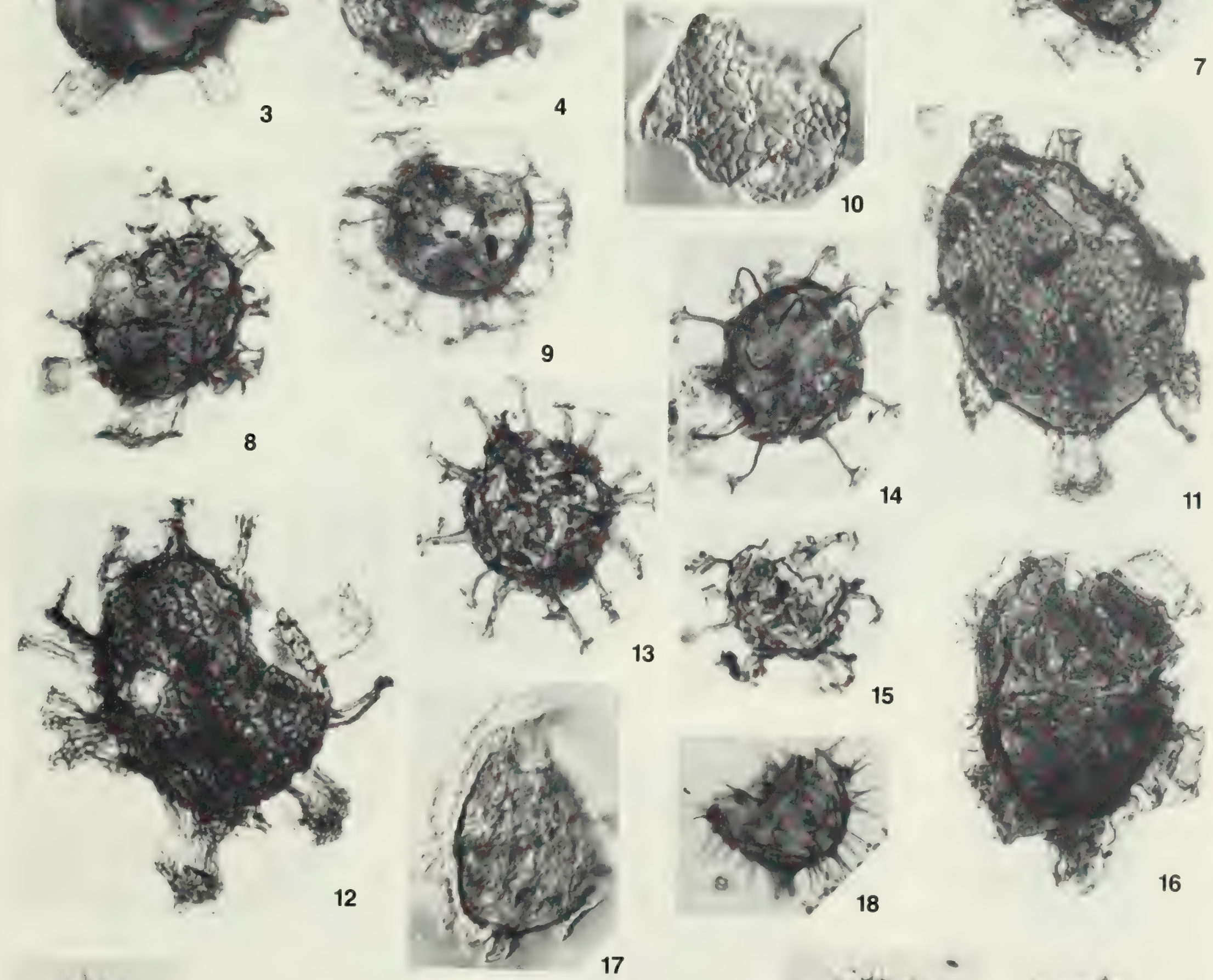
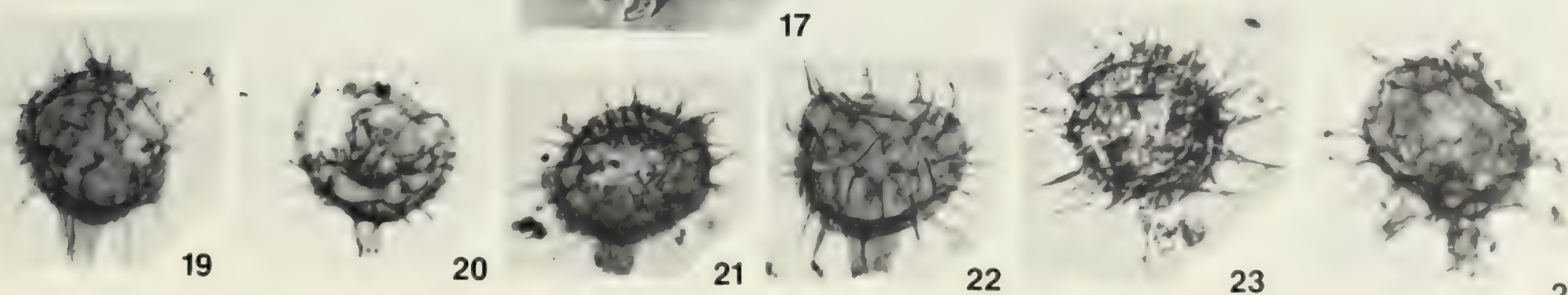
Plate 5, figs. 1-22.

All figures $\times 500$.

1. Exochosphaeridium muelleri Yun, Kukebai Formation $\left(\mathrm{K}_{2} \mathrm{k}\right)$, WG-20; $\mathrm{A}_{4} ; 43.6 / 101.7$.

Figs. 2,3. Exochosphaeridium sp. cf. E. muelleri Yun, Qimugen Formation $\left(\mathrm{E}_{1} \mathrm{q}\right)$.

2. QF-43; $\mathrm{A}_{4} ; 46.1 / 107.5$.

3. QF-43; $\mathrm{A}_{3} ; 50.4 / 103.8$.

4. Lingulodinium pugiatum (Drugg) Wall and Dale, Wulagen Formation $\left(\mathrm{E}_{2} \mathrm{w}\right), \mathrm{QF}-86 ; \mathrm{A}_{5} ; 37.6 / 101.4$.

Figs. 5-7. Kiokansium unituberculatum (Tasch) Stover and Evitt, Wuyitake Formation $\left(\mathrm{K}_{2} \mathrm{~W}\right)$.

5. WG-31; $A_{2} ; 44.9 / 102.5$.

6. WG-31; $A_{2} ; 44.1 / 104.6$.

7. WG-31; $\mathrm{A}_{11} ; 48.8 / 103.2$.

8. Operculodinium bergmannii (Archangelsky) Stover and Evitt, Qimugen Formation ( $\left.\mathrm{E}_{1} \mathrm{q}\right), \mathrm{QF}-43 ; \mathrm{A}_{4}$; $50.2 / 100.8$.

9. Operculodinium sp., Qimugen Formation $\left(\mathrm{E}_{1} \mathrm{q}\right)$, QF-43; $\mathrm{A}_{4} ; 42.3 / 100.3$. Specimen showing the precingular archeopyle $3^{\prime \prime}$ and short processes.

10. Protoellipsodinium sp., Kukebai Formation ( $\left.\mathrm{K}_{2} \mathrm{k}\right)$, WG-14; $\mathrm{A}_{2} ; 38.3 / 107.6$.

11. Protoellipsodinium clavulum Davey and Verdier, Kukebai Formation $\left(\mathrm{K}_{2} \mathrm{k}\right)$, WG-20; $\mathrm{A}_{4} ; 41.0 / 100.8$.

Figs. 12,13. Adnatosphaeridium multispinosum Williams and Downie, Wulagen Formation $\left(\mathrm{E}_{2} \mathrm{~W}\right)$.

12. QF-86; $\mathrm{A}_{1} ; 38.8 / 98.2$.

13. QF-86; $\mathrm{A}_{1} ; 49.7 / 104.0$.

14. Adnatosphaeridium vittatum Williams and Downie, Wulagen Formation $\left(\mathrm{E}_{2} \mathrm{~W}\right)$, WG-63; $\mathrm{A}_{2}$; 38.8/102.4.

Figs. 15,16. Adnatosphaeridium williamsii Islam, Wulagen Formation $\left(\mathrm{E}_{2} \mathrm{w}\right)$.

15. QF-86; $\mathrm{A}_{2} ; 40.6 / 109.3$.

16. QF-86; $\mathrm{A}_{5} ; 45.3 / 108.8$.

17. Adnatosphaeridium sp., Wulagen Formation $\left(\mathrm{E}_{2} \mathrm{~W}\right), \mathrm{QF}-86 ; \mathrm{A}_{2} ; 47.5 / 104.8$.

18. Areosphaeridium(?) actinocoronatum (Benedek) Stover and Evitt, Wulagen Formation $\left(\mathrm{E}_{2} \mathrm{~W}\right)$, QF-86; A $;$; 47.5/97.7.

19. Areosphaeridium arcuatum Eaton, Wulagen Formation $\left(\mathrm{E}_{2} \mathrm{~W}\right), \mathrm{QF}-86 ; \mathrm{A}_{1} ; 41.2 / 106.5$.

Figs. 20-22. Areosphaeridium diktyoplokum (Klumpp) Eaton, Wulagen Formation $\left(\mathrm{E}_{2} \mathrm{~W}\right)$.

20. QF-86; $\mathrm{A}_{3} ; 51.4 / 96.5$.

21. QF-86; $\mathrm{A}_{5} ; 47.3 / 109.4$

22. QF-86; $\mathrm{A}_{2} ; 39.4 / 109.5$ 

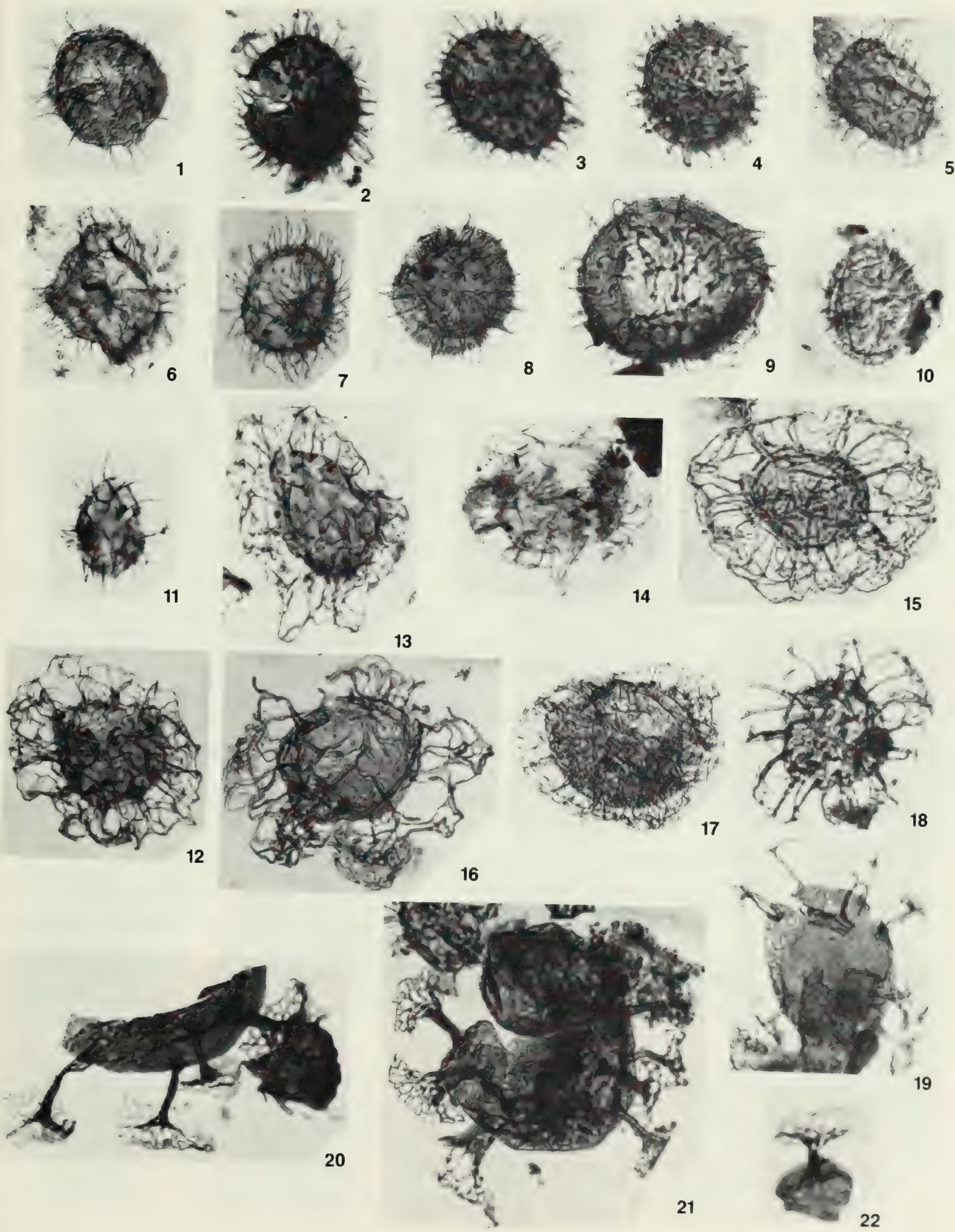
Plate 6, figs. 1-24.

All figures $\times 500$.

Figs. 1-3. Areosphaeridium fenestratum Bujak, Wulagen Formation $\left(\mathrm{E}_{2} \mathrm{w}\right)$.

1. QF-86; $\mathrm{A}_{4} ; 52.3 / 98.1$.

2. QF-86; $\mathrm{A}_{3} ; 51.4 / 96.6$.

3. QF-86; $\mathrm{G}_{3} ; 35.8 / 95.0$.

Figs. 4,5. Areosphaeridium multicornutum Eaton, Wulagen Formation $\left(\mathrm{E}_{2} \mathrm{w}\right)$.

4. QF-86; $\mathrm{A}_{4} ; 49.3 / 98.2$.

5. QF-86; $\mathrm{A}_{3} ; 46.3 / 99.7$.

Figs. 6,7. Diphyes colligerum (Deflandre and Cookson) Cookson, Wulagen Formation $\left(\mathrm{E}_{2} \mathrm{w}\right)$.

6. QF-86; $\mathrm{A}_{2} ; 47.5 / 107.8$.

7. QF-86; $\mathrm{G}_{2} ; 32.8 / 113.6$.

8. Diphyes cretaceum Yu and Zhang, Kukebai Formation $\left(\mathrm{K}_{2} \mathrm{k}\right)$, WG-14; $\mathrm{A}_{2} ; 39.5 / 104.6$.

9. Distatodinium ellipticum (Cookson) Eaton, Wulagen Formation $\left(\mathrm{E}_{2} \mathrm{~W}\right), \mathrm{WG}-63 ; \mathrm{A}_{5} ; 27.8 / 97.8$.

10. Hystrichokolpoma cinctum Klumpp, Bashibulake Formation ( $\left.\mathrm{E}_{3} \mathrm{~b}\right), \mathrm{QF}-94 ; \mathrm{A}_{1} ; 40.8 / 102.8$.

Figs. 11,12. Hystrichokolpoma granulata Eaton, Wulagen Formation $\left(\mathrm{E}_{2} \mathrm{~W}\right)$.

11. QF-86; $\mathrm{A}_{5} ; 51.0 / 104.4$.

12. QF-82; $\mathrm{A}_{4} ; 43.4 / 107.9$.

Figs. 13,14. Hystrichokolpoma rigaudiae Deflandre and Cookson, Wulagen Formation $\left(\mathrm{E}_{2} \mathrm{w}\right)$.

13. QF-86; $\mathrm{A}_{2} ; 50.8 / 97.6$.

14. QF-86; $\mathrm{A}_{5} ; 55.3 / 95.8$.

15. Hystrichokolpoma salacium Eaton, Wulagen Formation $\left(\mathrm{E}_{2} \mathrm{~W}\right), \mathrm{QF}-86 ; \mathrm{G}_{3} ; 30.0 / 108.1$.

16. Hystrichokolpoma sp. cf. H. unispina Williams and Downie, Wuyitake Formation $\left(\mathrm{K}_{2} \mathrm{~W}\right), \mathrm{WG}-31$; $\mathrm{A}_{4} ; 46.6199 .8$.

17. Hystrichosphaeridium salpingophorum Deflandre, emend. Davey and Williams, Wulagen Formation $\left(\mathrm{E}_{2} \mathrm{~W}\right), \mathrm{QF}-86 ; \mathrm{A}_{5} ; 49.6 / 95.0$.

Figs. 18,19. Hystrichosphaeridium (?) stellatum Maier, Kukebai Formation $\left(\mathrm{K}_{2} \mathrm{k}\right)$.

18. WG-20; $\mathrm{A}_{4} ; 39.0 / 104.1$

19. WG-20; $\mathrm{A}_{4} ; 47.8 / 100.8$.

20. Hystrichosphaeridium tubiferum (Ehrenberg) Deflandre, Wulagen Formation $\left(\mathrm{E}_{2} \mathrm{w}\right), \mathrm{QF}-82 ; \mathrm{A}_{1}$; $50.2 / 101.4$

21. Hystrichosphaeridium tubiferum subsp. brevispinum (Davey and Williams) Lentin and Williams, Qimugen Formation $\left(\mathrm{E}_{1} \mathrm{q}\right), \mathrm{QF}-43 ; \mathrm{A}_{2} ; 32.7 / 108.9$.

22. Litosphaeridium siphoniphorum (Cookson and Eisenack) Davey and Williams, Kukebai Formation ( $\left.\mathrm{K}_{2} \mathrm{k}\right)$, WG-20; $\mathrm{A}_{4} ; 44.0 / 107.4$.

Figs. 23,24. Oligosphaeridium complex (White) Davey and Williams, Kukebai Formation $\left(\mathrm{K}_{2} \mathrm{k}\right.$ ).

23. WG-16; $\mathrm{A}_{6} ; 28.9 / 109.5$.

24. WG-20; $\mathrm{A}_{4} ; 37.0 / 99.6$. 


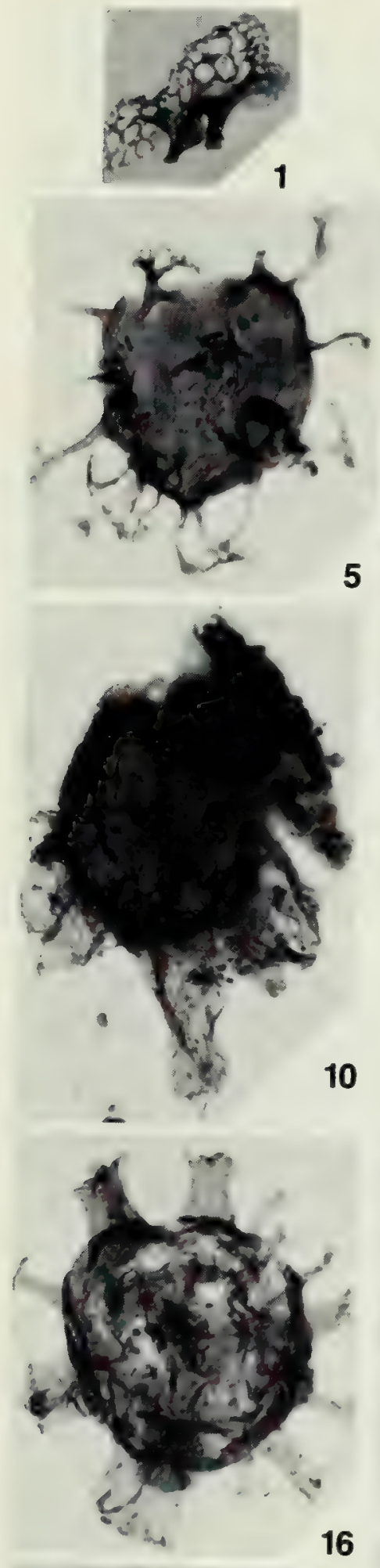

De.
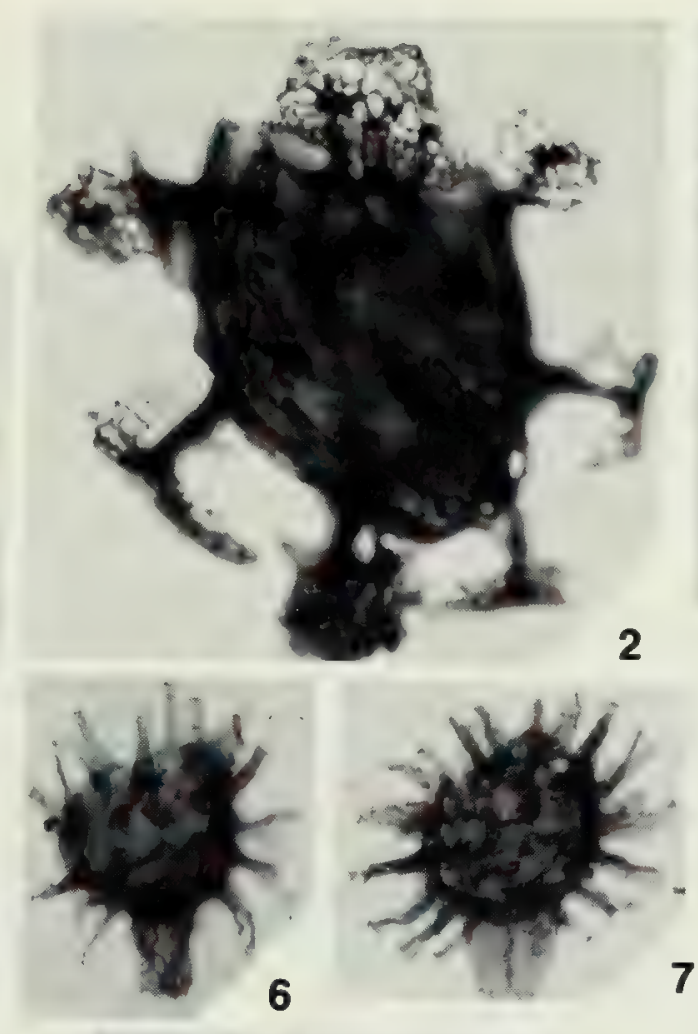

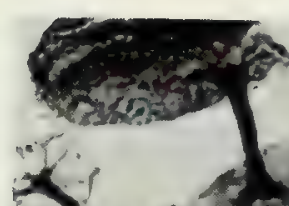
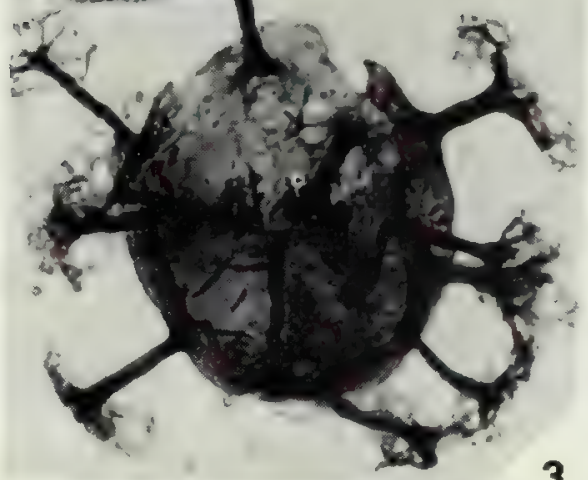

3
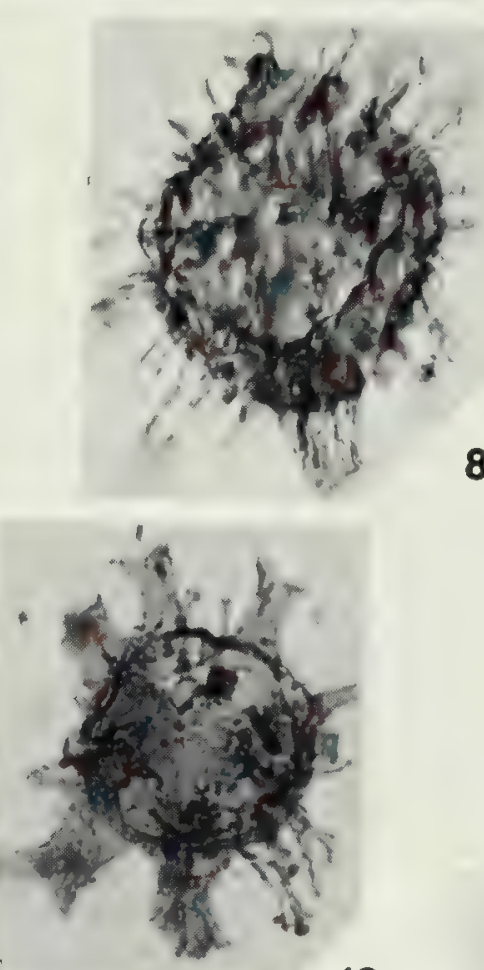

12

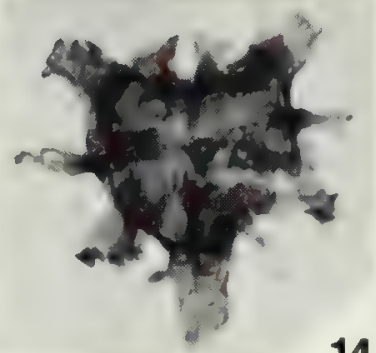

14
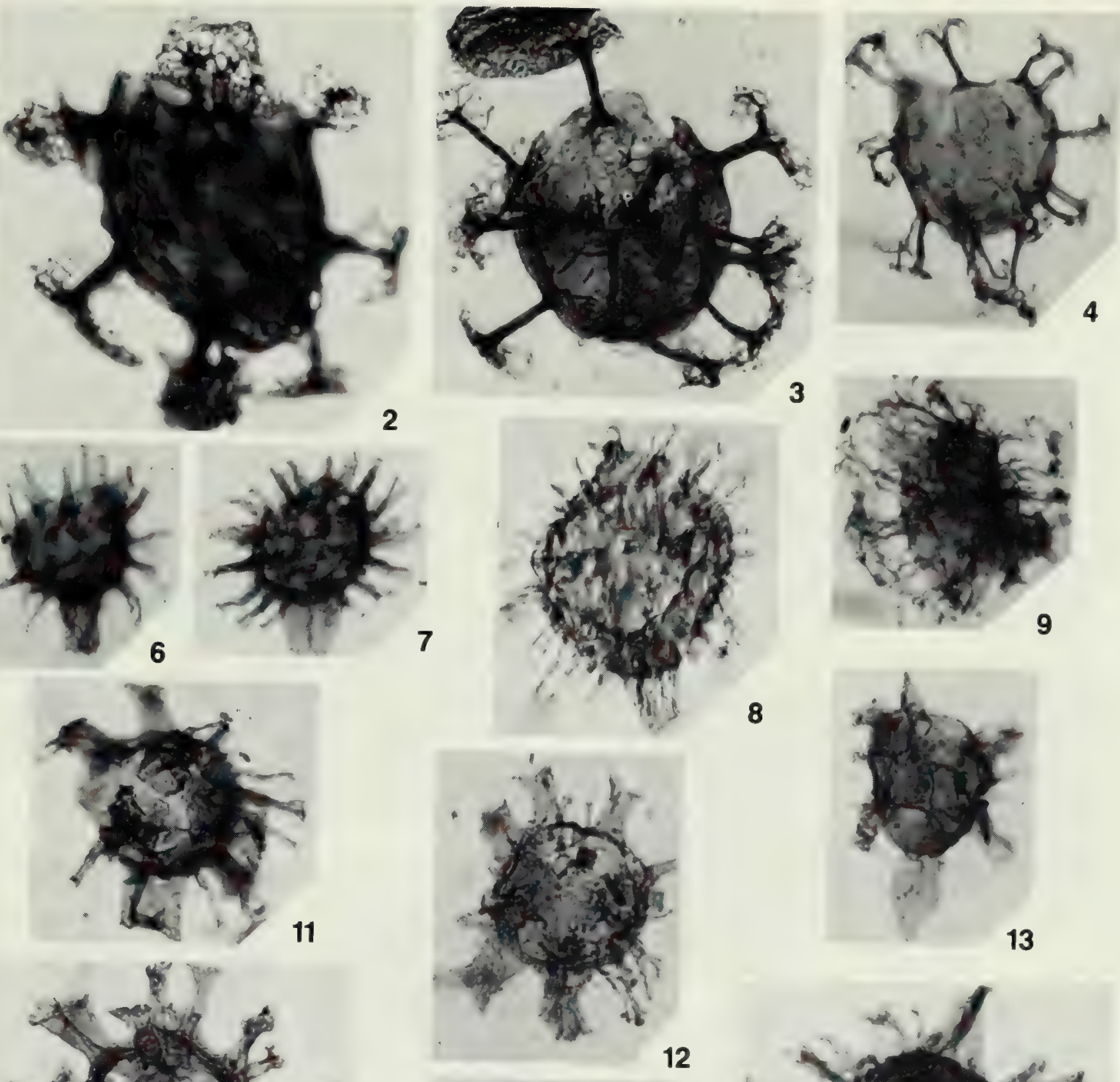

$+253 x+4$

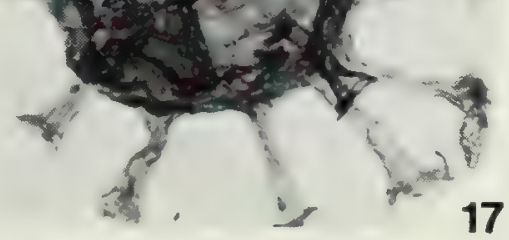

$16=7+7$

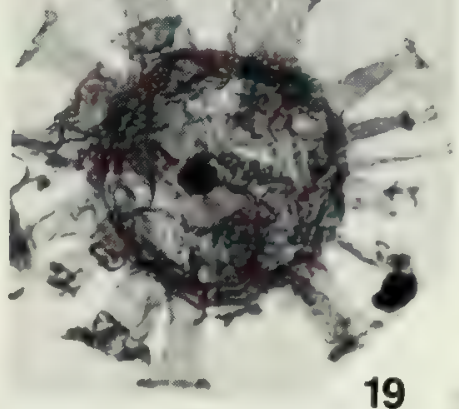

19

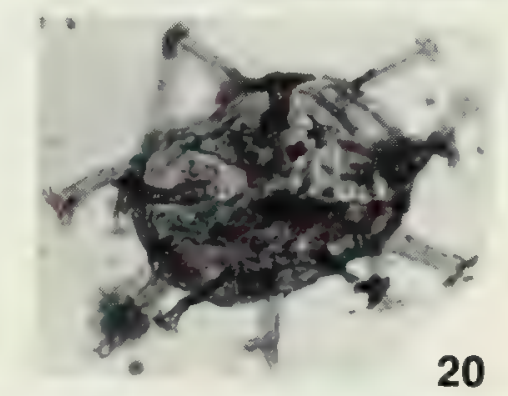

13
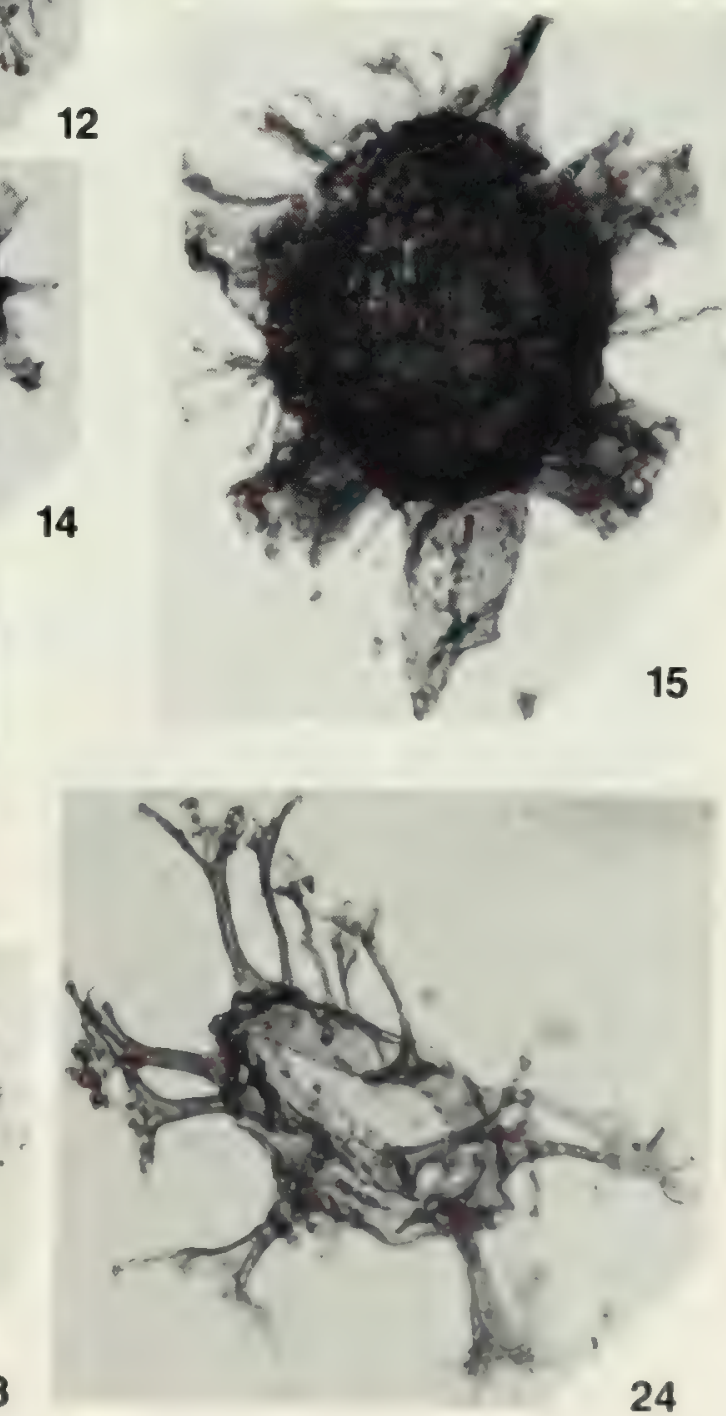

the

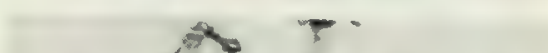


Plate 7, figs. $1-25$.

All figures $\times 500$.

1. Oligosphaeridium sp. cf. O. irregulare (Pocock) Davey and Williams, Wulagen Formation $\left(\mathrm{E}_{2} \mathrm{w}\right)$, QF-82; $\mathrm{A}_{1} ; 39.4 / 93.7$.

Figs. 2-6. Oligosphaeridium pulcherrimum (Deflandre and Cookson) Davey and Williams, Kukebai Formation $\left(\mathrm{K}_{2} \mathrm{k}\right)$.

2. WG-10; $\mathrm{A}_{4} ; 47.0 / 110.2$.

3. WG-20; $\mathrm{A}_{4} ; 42.0 / 105.0$.

4. WG-20; $\mathrm{A}_{1} ; 40.3 / 108.4$.

5. WG-20; $\mathrm{A}_{1} ; 40.6 / 106.4$.

6. WG-20; $\mathrm{A}_{4} ; 40.3 / 101.1$.

Figs. 7,8. Surculosphaeridium sp., Wulagen Formation $\left(\mathrm{E}_{2} \mathrm{w}\right)$.

7. QF-86; A $;$;5.5/109.8.

8. QF-86; $\mathrm{A}_{4} ; 46.7 / 97.6$.

Figs. 9,10. Systematophora ancyrea Cookson and Eisenack, Wulagen Formation $\left(\mathrm{E}_{2} \mathrm{w}\right)$.

9. QF-82; $\mathrm{A}_{1} ; 50.5 / 105.4$.

10. QF-82; $\mathrm{A}_{4} ; 43.4 / 104.2$.

11. Tanyosphaeridium salpinx Norvick, Wulagen Formation ( $\left.\mathrm{E}_{2} \mathrm{w}\right), \mathrm{QF}-86 ; \mathrm{A}_{5} ; 49.9 / 101.2$.

Figs. 12,13. Tanyosphaeridium sp. A, Wulagen Formation $\left(\mathrm{E}_{2} \mathrm{~W}\right)$.

12. QF-86; $\mathrm{A}_{5} ; 47.2 / 101.4$.

13. QF-86; $\mathrm{A}_{4} ; 40.4 / 100.5$.

Figs. 14,15. Tanyosphaeridium sp. B, Wulagen Formation $\left(\mathrm{E}_{2} \mathrm{~W}\right)$.

14. QF-86; $\mathrm{A}_{4} ; 40.4 / 100.5$.

15. QF-86; $\mathrm{A}_{5} ; 53.0 / 102.8$. Specimen showing the hinged operculum of apical plate.

16. Cleistosphaeridium diversispinosum Davey et al., Bashibulake Formation $\left(\mathrm{E}_{3} \mathrm{~b}\right), \mathrm{WG}-70 ; \mathbf{A}_{4}$; 49.5/103.7.

Figs. 17,18. Cleistosphaeridium (?) multifurcatum (Deflandre) Davey et al., Wulagen Formation $\left(\mathrm{E}_{2} \mathrm{~W}\right)$.

17. QF-86; $\mathrm{A}_{4} ; 47.0 / 100.7$.

18. QF-86; $\mathrm{A}_{4} ; 48.5 / 101.0$.

19. Cleistosphaeridium (?) multispinosum (Singh) Brideaux, Kukebai Formation $\left(\mathrm{K}_{2} \mathrm{k}\right)$, WG-14; $\mathbf{A}_{2}$; 40.6/104.9.

20. Cleistosphaeridium perforoconum Yun, Kukebai Formation $\left(\mathrm{K}_{2} \mathrm{k}\right)$, WG-20; $\mathrm{A}_{4} ; 42.5 / 98.6$.

Figs. 21-23. Cleistosphaeridium radiculopsis sp. nov., Wuyitake Formation $\left(\mathrm{K}_{2} \mathrm{~W}\right)$.

21. Holotype, WG-31; $A_{1} ; 39.8 / 102.4$. Specimen showing operculum detached.

22. WG-31; $\mathrm{A}_{2} ; 53.7 / 95.2$.

23. Paratype. WG-31; $A_{1} ; 37.5 / 109.1$.

Figs. 24,25. Florentinia cooksoniae (Singh) Duxbury, Wuyitake Formation $\left(\mathrm{K}_{2} \mathrm{~W}\right)$.

24. WG-31; $\mathrm{A}_{1} ; 51.3 / 102.6$.

25. WG-31; $\mathrm{A}_{2} ; 37.8 / 98.1$. 

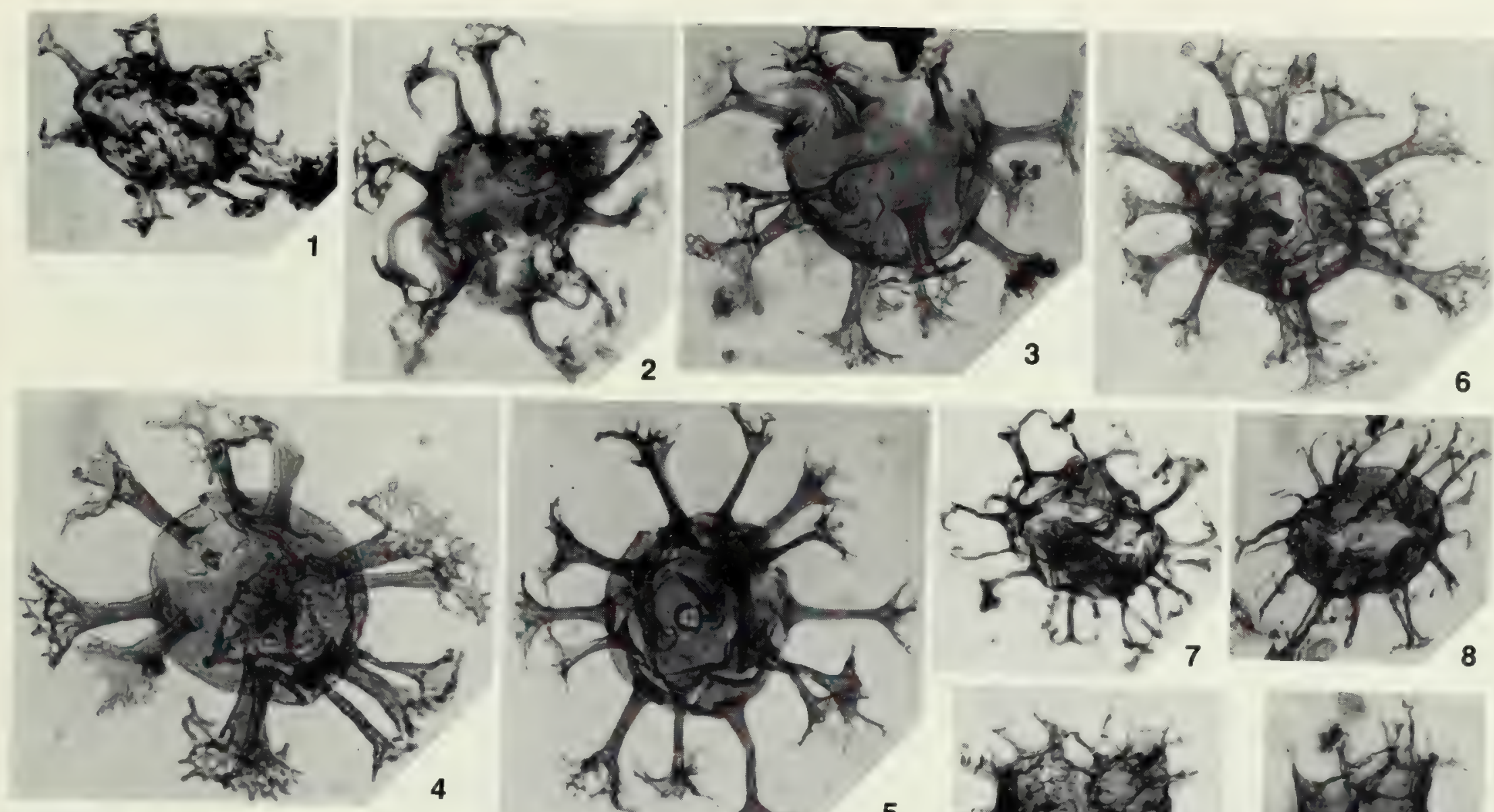
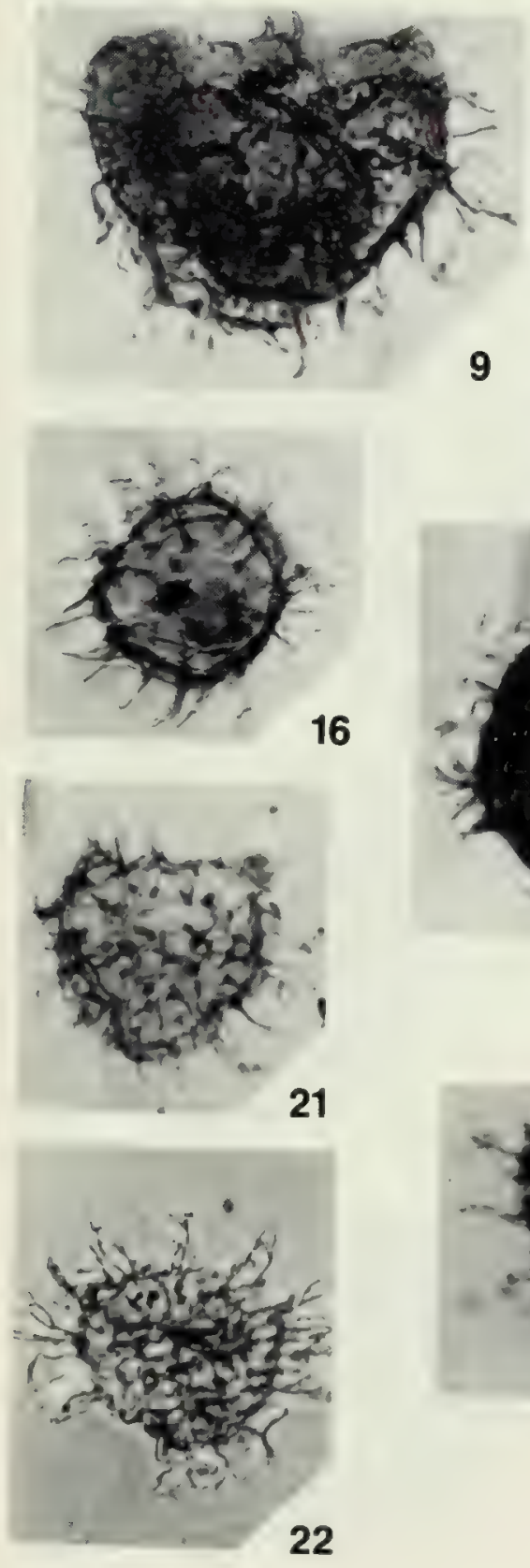
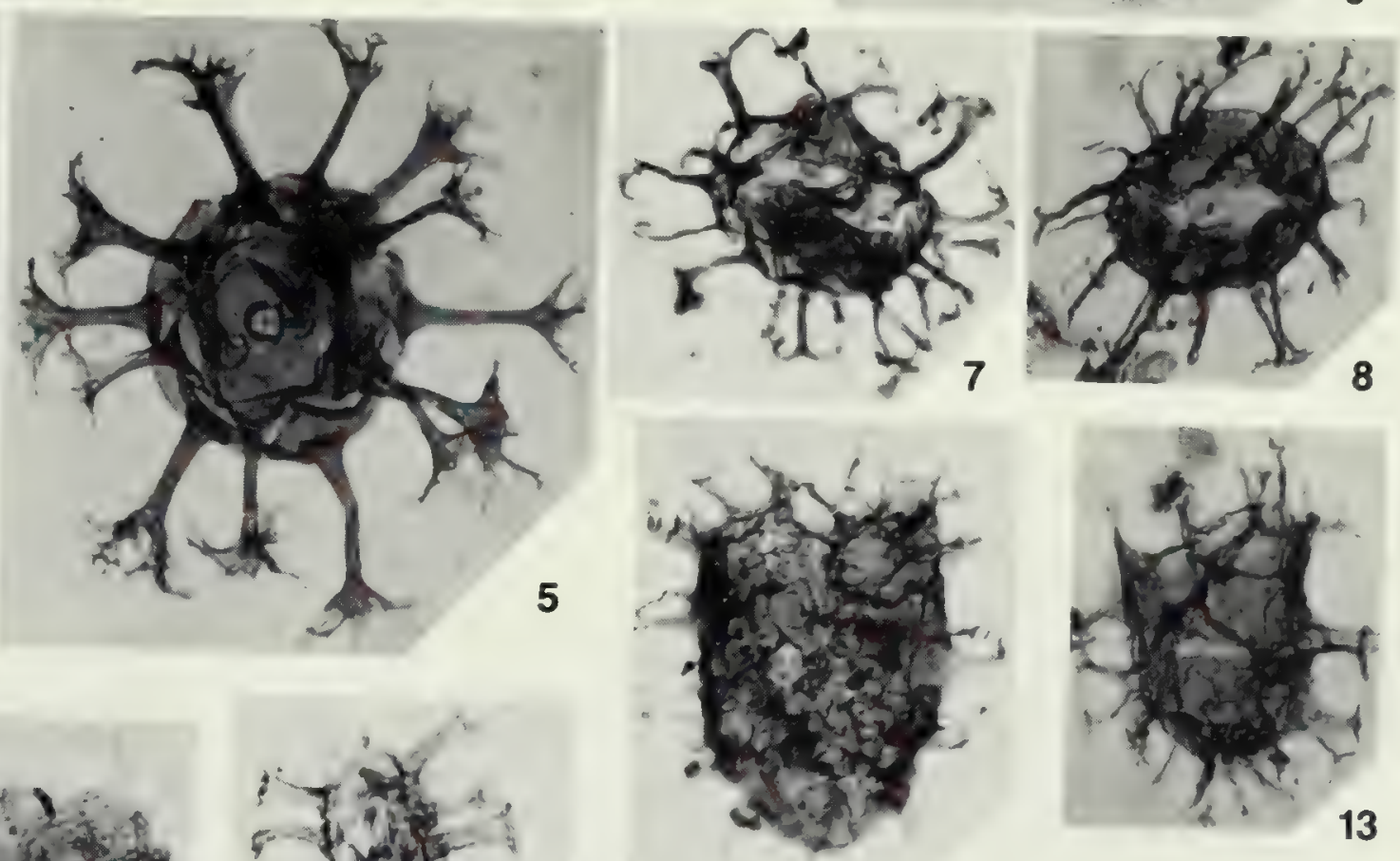

12
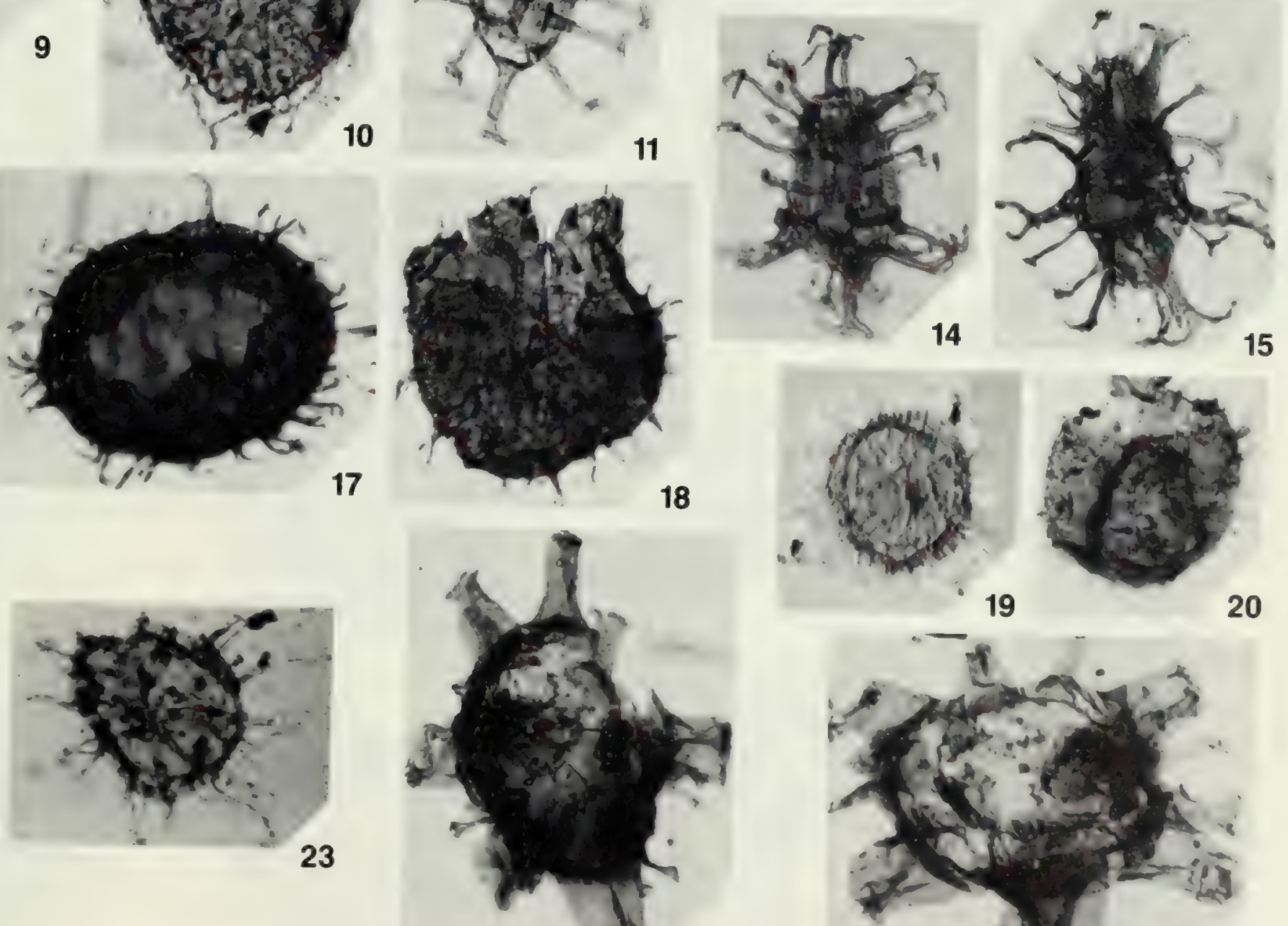

23
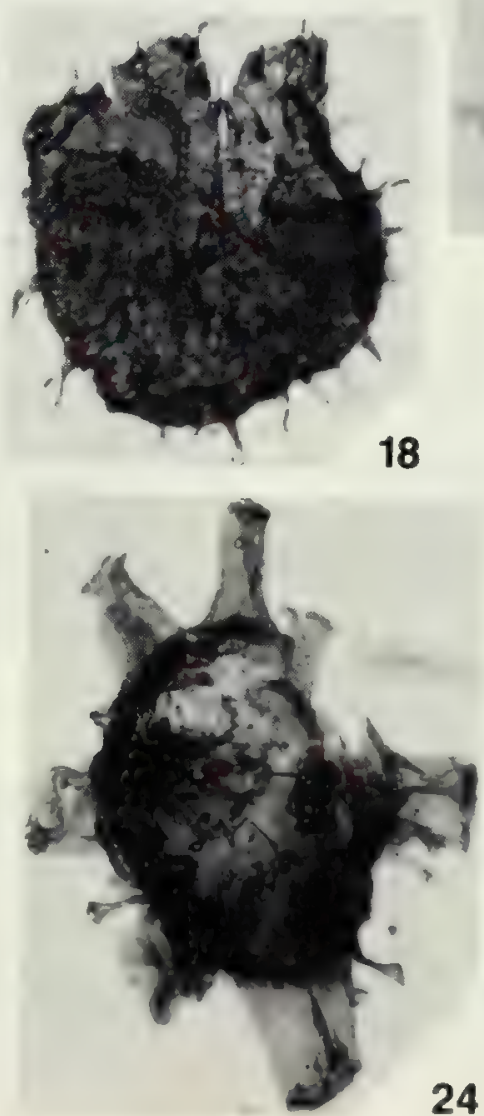

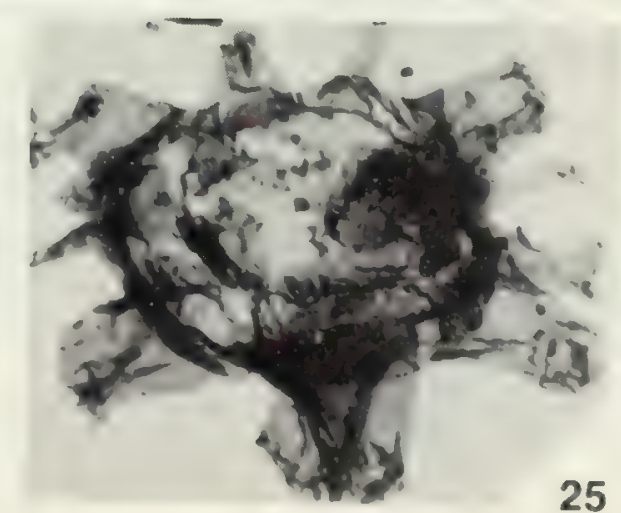


PLATE 8, figs. 1-26.

All figures $\times 500$.

1. Florentinia deanei (Davey and Williams) Davey and Verdier, Wuyitake Formation $\left(\mathrm{K}_{2} \mathrm{~W}\right)$, WG-31; $\mathbf{A}_{2}$; $45.2 / 100.5$.

Figs. 2-5. Florentinia laciniata subsp. propria subsp. nov., Wulagen Formation $\left(\mathrm{E}_{2} \mathrm{~W}\right)$.

2. Holotype, QF-86; $\mathrm{A}_{5} ; 56.4 / 101.8$.

3. QF-86; $\mathrm{A}_{2} ; 39.0 / 105.0$.

4. Paratype, WG-63; $A_{1} ; 36.4 / 100.0$. Three specimens showing the combination archeopyle formed by the loss of apical and precingular 3 " plates.

5. QF-86; $\mathrm{A}_{2} ; 47.6 / 108.0$. Specimen showing the apical plates detached and the precingular 3" attached.

Figs. 6-8. Florentinia mantellii (Davey and Williams) Davey and Verdier, Kukebai Formation $\left(\mathrm{K}_{2} \mathrm{k}\right)$.

6. WG- $20 ; \mathrm{A}_{1} ; 44.0 / 99.3$.

7. WG-20; $A_{4} ; 48.0 / 109.2$.

8. WG-20; $A_{1} ; 40.5 / 105.7$.

Figs. 9,10. Homotryblium abbreviatum Eaton, Wulagen Formation $\left(\mathrm{E}_{2} \mathrm{w}\right)$.

9. QF-86; $\mathrm{A}_{5} ; 45.0 / 97.3$.

10. QF-86; A 4 ; 52.3/98.5.

Figs. 11,12. Homotryblium pallidum Davey and Williams, Wulagen Formation $\left(\mathrm{E}_{2} \mathrm{~W}\right)$.

11. QF-82; $\mathrm{A}_{4} ; 43.5 / 104.3$.

12. QF-86; $\mathrm{A}_{4} ; 49.3 / 101.3$.

Figs. 13,14. Homotryblium tenuispinosum Davey and Williams, Wulagen Formation $\left(\mathrm{E}_{2} \mathrm{~W}\right)$.

13. QF-86; $\mathrm{A}_{5} ; 46.6 / 98.7$.

14. QF-86; $\mathrm{A}_{5} ; 51.6 / 103.1$.

15. Alisocysta circumtabulata (Drugg) Stover and Evitt, Qimugen Formation $\left(\mathrm{E}_{1} \mathrm{q}\right), \mathrm{QF}-43$; $\mathrm{A}_{4}$; 36.9/102.2.

16. Schematophora speciosa Deflandre and Cookson, Wulagen Formation ( $\left.\mathrm{E}_{2} \mathrm{w}\right)$, WG-63; $\mathrm{A}_{2} ; 29.7 / 97.5$.

Figs. 17-20. Batiacasphaera hystrieosa sp. nov., Wulagen Formation $\left(\mathrm{E}_{2} \mathrm{~W}\right)$.

17. WG-63; $\mathrm{A}_{3} ; 34.4 / 110.2$.

18. Holotype, WG-63; $\mathrm{A}_{1} ; 37.3 / 109.6$.

19. Paratype, WG-63; $\mathrm{A}_{2} ; 35.0 / 107.2$.

20. WG-63; $\mathrm{A}_{5} ; 27.3 / 97.3$. Apical view.

Figs. 21,22. Sentusidinium stipulatum sp. nov., Wulagen Formation $\left(\mathrm{E}_{2} \mathrm{w}\right)$.

21. QF-82; $\mathrm{A}_{1} ; 52.6 / 93.2$.

22. Holotype, QF-82; $\mathrm{A}_{5} ; 43.7 / 100.8$. Specimen showing the operculum (apical plates) attached.

23. Trigonopyxidia ginella (Cookson and Eisenack) Downie and Sarjeant, Qimugen Formation ( $\left.E_{1} q\right)$, QF-43; A4; 52.4/98.7.

24. Wallodinium anglicum (Cookson and Hughes) Lentin and Williams, Kukebai Formation $\left(\mathrm{K}_{2} \mathrm{k}\right)$, WG- $14 ; \mathrm{A}_{4} ; 43.0 / 97.9$.

25. Wallodinium lunum (Cookson and Eisenack) Lentin and Williams, Kukebai Formation $\left(\mathrm{K}_{2} \mathrm{k}\right)$, WG-13; $\mathrm{A}_{7} ; 47.5 / 105.3$.

26. Polysphaeridium subtile Davey and Williams, Wulagen Formation ( $\left.\mathrm{E}_{2} \mathrm{~W}\right), \mathrm{QF}-86 ; \mathrm{A}_{5} ; 44.1 / 92.3$. 

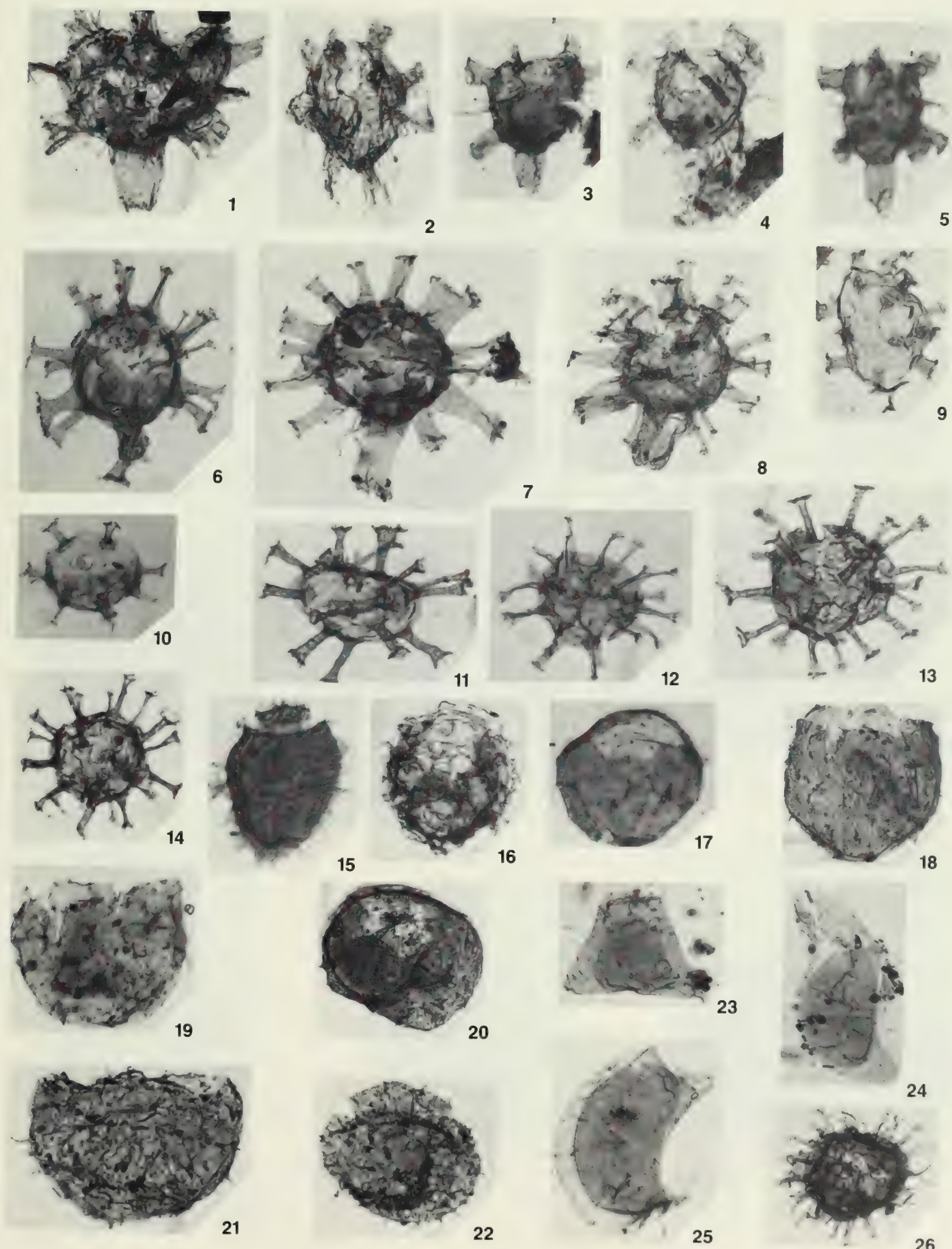

24

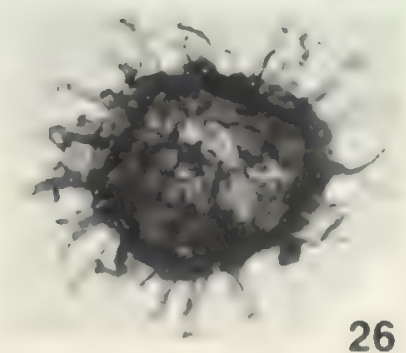


Plate 9, figs. 1-16.

All figures $\times 500$ unless otherwise stated.

Figs. 1,2. Alterbidinium emulatum sp. nov., Kukebai Formation $\left(\mathrm{K}_{2} \mathrm{k}\right)$.

1. Holotype, WG-18; $\mathrm{A}_{2} ; 40.5 / 98.4$.

2. Paratype, WG-18; $\mathrm{A}_{2} ; 42.0 / 99.3$.

3. Ceratiopsis albertii (Corradini) Lentin and Williams, Wulagen Formation $\left(\mathrm{E}_{2} \mathrm{w}\right)$, WG-63; $\mathrm{A}_{5}$; $36.2 / 99.5$.

Figs. 4,5. Ceratiopsis depressa (Morgenroth) Lentin and Williams.

4. Bashibulake Formation $\left(\mathrm{E}_{3} \mathrm{~b}\right), \mathrm{WG}-72 ; \mathrm{A}_{1} ; 20.5 / 101.3(\times 730)$.

5. Wulagen Formation ( $\left.\mathrm{E}_{2} \mathrm{~W}\right), \mathrm{QF}-86 ; \mathrm{A}_{5} ; 48.6 / 111.6$.

6. Ceratiopsis diebelii (Alberti) Vozzhennikova, Wulagen Formation ( $\left.\mathrm{E}_{2} \mathrm{~W}\right)$, WG-63; $\mathrm{A}_{4} ; 27.0 / 108.4$.

7. Ceratiopsis leptoderma Vozzhennikova, Bashibulake Formation ( $\left.\mathrm{E}_{3} \mathrm{~b}\right), \mathrm{WG}-70 ; \mathrm{A}_{8} ; 47.4 / 103.8$.

8. Ceratiopsis sibirica (Vozzhennikova) Lentin and Williams, Qimugen Formation ( $\left.\mathrm{E}_{2} \mathrm{q}\right), \mathrm{QF}-45 ; \mathrm{G}_{1}$; 49.2/104.0.

9. Ceratiopsis speciosa (Alberti) Lentin and Williams, Qimugen Formation ( $\left.E_{1} q\right), Q F-49 ; A_{2} ; 42.0 / 98.2$.

Figs. 10-12. Ceratiopsis speciosa subsp. elongata subsp. nov., Qimugen Formation ( $\left.\mathrm{E}_{1} \mathrm{q}\right)$.

10. Holotype, QF-49; $\mathrm{A}_{1} ; 45.7 / 104.0$.

11. Paratype, QF-51; $A_{1} ; 19.0 / 106.2$.

12. QF-43; $\mathrm{A}_{2} ; 43.5 / 93.3$.

13. Ceratiopsis speciosa subsp. glabra (Gocht) Lentin and Williams, Qimugen Formation $\left(\mathrm{E}_{1} \mathrm{q}\right), \mathrm{QF}-51$; $\mathrm{A}_{1} ; 20.0 / 105.3$.

14. Ceratiopsis sp., Bashibulake Formation ( $\left.\mathrm{E}_{3} \mathrm{~b}\right)$, WG-72; $\mathrm{A}_{1} ; 31.9 / 103.0$.

15. Chatangiella serratula (Cookson and Eisenack) Lentin and Williams, Kukebai Formation $\left(\mathrm{K}_{2} \mathrm{k}\right)$, WG-18; $\mathrm{A}_{2} ; 45.6 / 96.4$.

16. An operculum (both perioperculum and endo-operculum) of Deflandrea (possibly comparable with D. andromiensis Vozzhennikova), Qimugen Formation $\left(\mathrm{E}_{1} \mathrm{q}\right)$, QF-51; $\mathrm{A}_{1} ; 25.2 / 104.8$, showing the broad hexagonal intercalary 2 a plate and its granulate wall surface. 

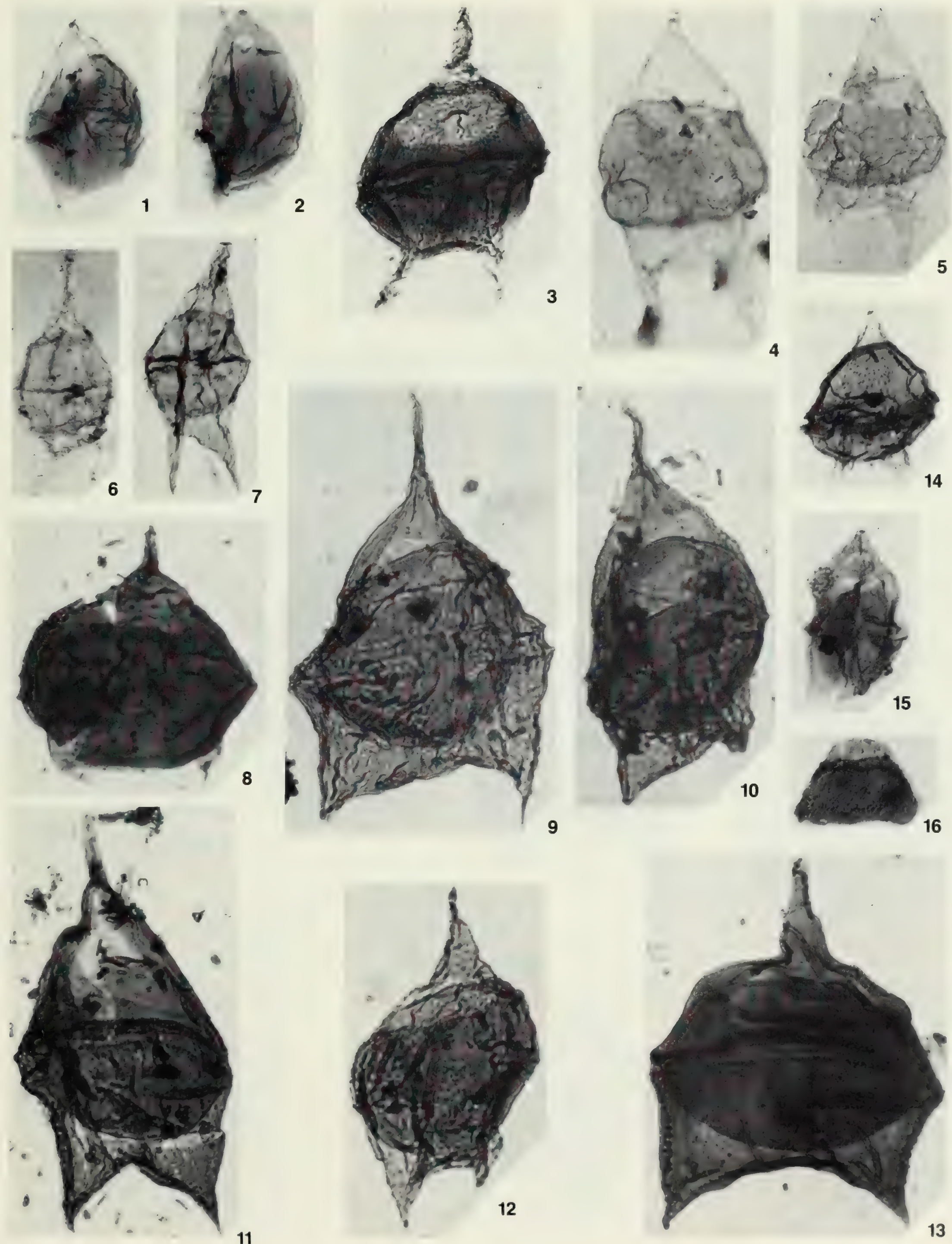
PLATE 10 , figs. $1-15$.

All figures $\times 500$.

1. Deflandrea andromiensis Vozzhennikova, Qimugen Formation ( $\left.\mathrm{E}_{1} \mathrm{q}\right)$, QF-49; $\mathrm{A}_{3} ; 45.0 / 107.2$.

2. Deflandrea sp. cf. D. arcuata Vozzhennikova, Bashibulake Formation $\left(\mathrm{E}_{3} \mathrm{~b}\right), \mathrm{WG}-70 ; \mathrm{A}_{3} ;$ 46.0/103.1.

3. Deflandrea granulata Menendez, Bashibulake Formation ( $\left.\mathrm{E}_{3} \mathrm{~b}\right), \mathrm{WG}-72 ; \mathrm{A}_{2} ; 28.1 / 98.7$.

Figs. 4-6. Deflandrea intrasphaerula sp. nov., Bashibulake Formation $\left(\mathrm{E}_{3} \mathrm{~b}\right)$.

4. Holotype, WG-74; $\mathrm{A}_{2} ; 44.8 / 108.0$.

5. Paratype, WG-70; $\mathrm{A}_{10} ; 41.4 / 104.4$.

6. WG-74; $\mathrm{A}_{4} ; 40.5 / 100.4$.

Figs. 7-10. Deflandrea musculopsis sp. nov.

7. Wulagen Formation ( $\left.\mathrm{E}_{2} \mathrm{w}\right), \mathrm{QF}-86 ; \mathrm{A}_{1} ; 52.8 / 100.0$

8. Holotype, Wulagen Formation $\left(\mathrm{E}_{2} \mathrm{~W}\right), \mathrm{QF}-86 ; \mathrm{A}_{5} ; 52.1 / 97.1$.

9. Wulagen Formation $\left(\mathrm{E}_{2} \mathrm{~W}\right), \mathrm{QF}-86 ; \mathrm{A}_{5} ; 53.7 / 99.5$.

10. Paratype, Qimugen Formation ( $\left.E_{1} q\right), S M-77 ; A_{2} ; 34.0 / 107.4$.

Figs. 11,12. Deflandrea oebisfeldensis Alberti, Qimugen Formation ( $\left.\mathrm{E}_{1} \mathrm{q}\right)$.

11. QF-49; $\mathrm{A}_{1} ; 45.0 / 109.3$.

12. QF-49; $\mathrm{A}_{1} ; 50.5 / 98.8$.

Figs. 13-15. Deflandrea phosphoritica subsp. phosphoritica Eisenack.

13. Wulagen Formation ( $\left.E_{2} w\right)$, WG-63; $A_{1} ; 43.0 / 111.1$.

14. Bashibulake Formation ( $\left.E_{3} b\right)$, WG-72; $A_{1} ; 43.0 / 104.1$

15. Bashibulake Formation ( $\left.E_{3} b\right), W G-74 ; A_{1} ; 47.1 / 101.9$. 

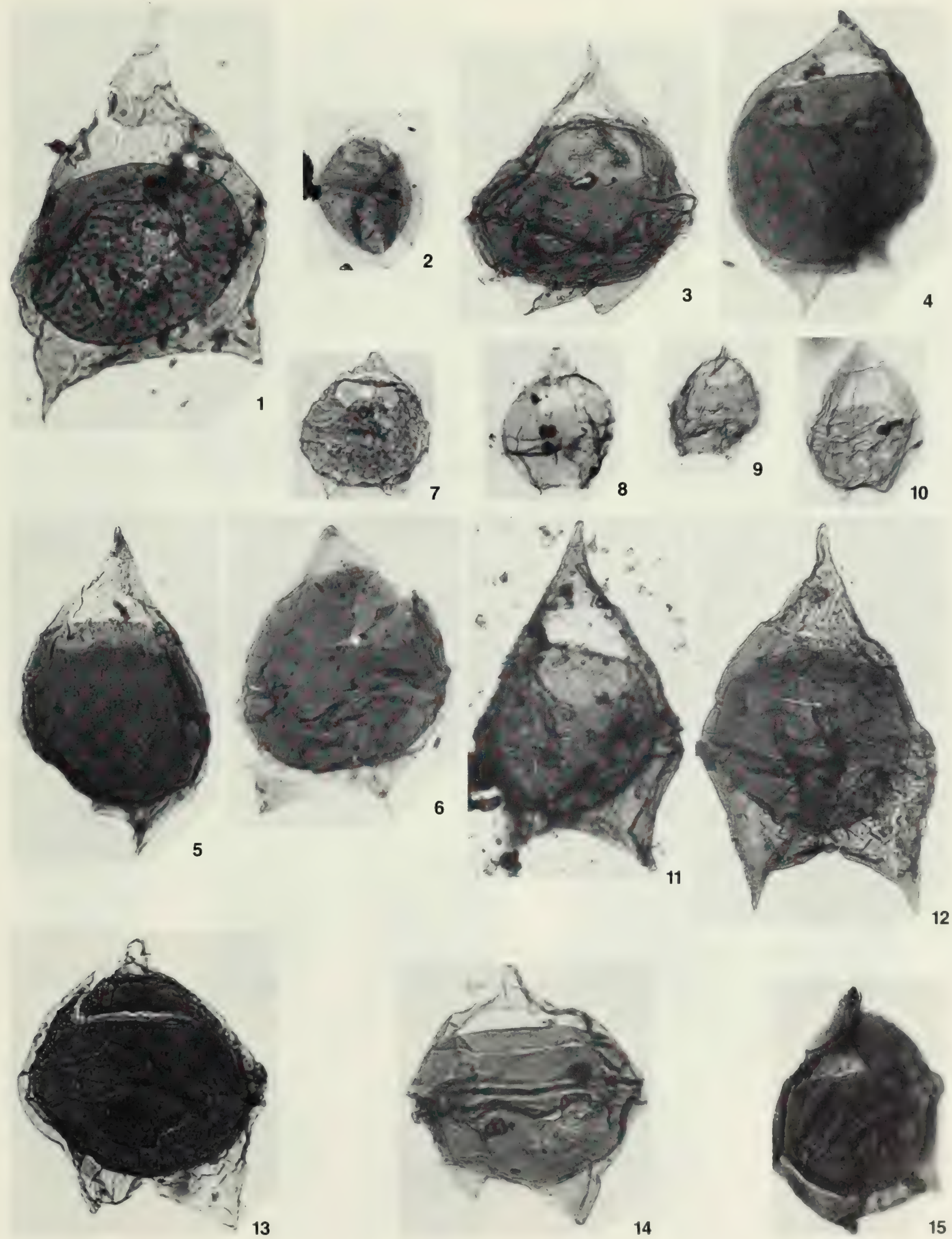
Plate 11, figs. 1-26.

All figures $\times 500$ unless otherwise stated.

Figs. 1,2. Deflandrea robusta Deflandre and Cookson, Bashibulake Formation $\left(\mathrm{E}_{3} \mathrm{~b}\right)$.

1. WG-72; $\mathrm{A}_{3} ; 46.3 / 102.8$.

2. WG-77; $A_{1} ; 45.2 / 104.6$.

Figs. 3,4. Diconodinium multispinum (Deflandre and Cookson) Eisenack and Cookson, emend. Morgan, Kukebai Formation $\left(\mathrm{K}_{2} \mathrm{k}\right)$.

3. WG-13; $\mathrm{B}_{1} ; 44.4 / 99.7$.

4. WG-13; $B_{2} ; 11.8 / 100.0$.

5. Diconodinium pelliferum (Cookson and Eisenack) Eisenack and Cookson, emend. Morgan, Kukebai Formation $\left(\mathrm{K}_{2} \mathrm{k}\right)$, WG-13; $\mathbf{B}_{1} ; 45.2 / 104.6$.

Figs. 6,7. Eucladinium gambangense (Cookson and Eisenack) Stover and Evitt, Kukebai Formation $\left(\mathrm{K}_{2} \mathrm{k}\right)$.

6. WG-24; $A_{2} ; 48.5 / 100.2$

7. WG-18; $A_{2} ; 41.5 / 99.3$.

Figs. 8-10. Eurydinium eyrense (Cookson and Eisenack) Stover and Evitt, Kukebai Formation $\left(\mathrm{K}_{2} \mathrm{k}\right)$.

8. WG-18; $\mathrm{A}_{3} ; 46.0 / 103.8$.

9. WG-18; $A_{2} ; 45.5 / 100.6$.

10. WG-18; $\mathrm{A}_{2} ; 47.5 / 103.8$.

11. Eurydinium ingramii (Cookson and Eisenack) Stover and Evitt, Kukebai Formation ( $\left.\mathrm{K}_{2} \mathrm{k}\right)$, WG-18; $\mathrm{A}_{3} ; 47.2 / 104.2$.

Figs. 12-14. Eurydinium raijae (Kjellström) Stover and Evitt, Kukebai Formation $\left(\mathrm{K}_{2} \mathrm{k}\right)$.

12. WG-18; $\mathrm{A}_{3} ; 45.4 / 105.1$.

13. WG-18; $A_{2} ; 37.2 / 99.8$.

14. Holotype, WG-18; $\mathrm{A}_{2} ; 40.3 / 99.2$. Specimen showing the hinged operculum.

Figs. 15-17. Eurydinium tempestivum sp. nov., Kukebai Formation $\left(\mathrm{K}_{2} \mathrm{k}\right)$.

15. WG-18; $A_{1} ; 45.0 / 106.2$.

16. Paratype, WG-18; $\mathrm{A}_{2} ; 43.0 / 94.2$. Specimen showing the hinged operculum.

17. Holotype, WG-18; $\mathrm{A}_{2} ; 47.6 / 102.3$.

18. Isabelidinium acuminatum (Cookson and Eisenack) Stover and Evitt, Kukebai Formation $\left(\mathrm{K}_{2} \mathrm{k}\right)$, WG-20; A4; 49.7/109.6.

19. Isabelidinium cooksoniae (Alberti) Lentin and Williams, Kukebai Formation $\left(\mathrm{K}_{2} \mathrm{k}\right)$, WG-24; $\mathrm{A}_{1}$; 42.3/111.5.

20. Isabelidinium korojonense (Cookson and Eisenack) Lentin and Williams, Kukebai Formation $\left(\mathrm{K}_{2} \mathrm{k}\right)$, WG-18; $\mathrm{A}_{2} ; 43.6 / 100.0$.

Figs. 21-23. Lentinia serrata Bujak, Bashibulake Formation ( $\left.\mathrm{E}_{3} \mathrm{~b}\right)$.

21. WG-75; $\mathrm{A}_{1} ; 48.3 / 104.0$.

22. WG-72; $A_{2} ; 29.5 / 102.1(\times 700)$.

23. WG-72; $A_{2} ; 40.0 / 98.6$.

24. Lentinia serrata Bujak, Qimugen Formation ( $\left.\mathrm{E}_{1} \mathrm{q}\right), \mathrm{SM}-77 ; \mathrm{A}_{4} ; 23.5 / 103.7$.

Figs. 25,26. Trithyrodinium evittii Drugg, Kukebai Formation $\left(\mathrm{K}_{2} \mathrm{k}\right)$.

25. WG-18; $\mathrm{A}_{2} ; 43.5 / 101.7$. Specimen showing the 3I endopyle formed by loss of three intercalary plates.

26. WG-13; $A_{6} ; 50.0 / 100.2$. Specimen showing the periphragm attached to endophragm and the attached opercula of $3 \mathrm{I}$ plates. 

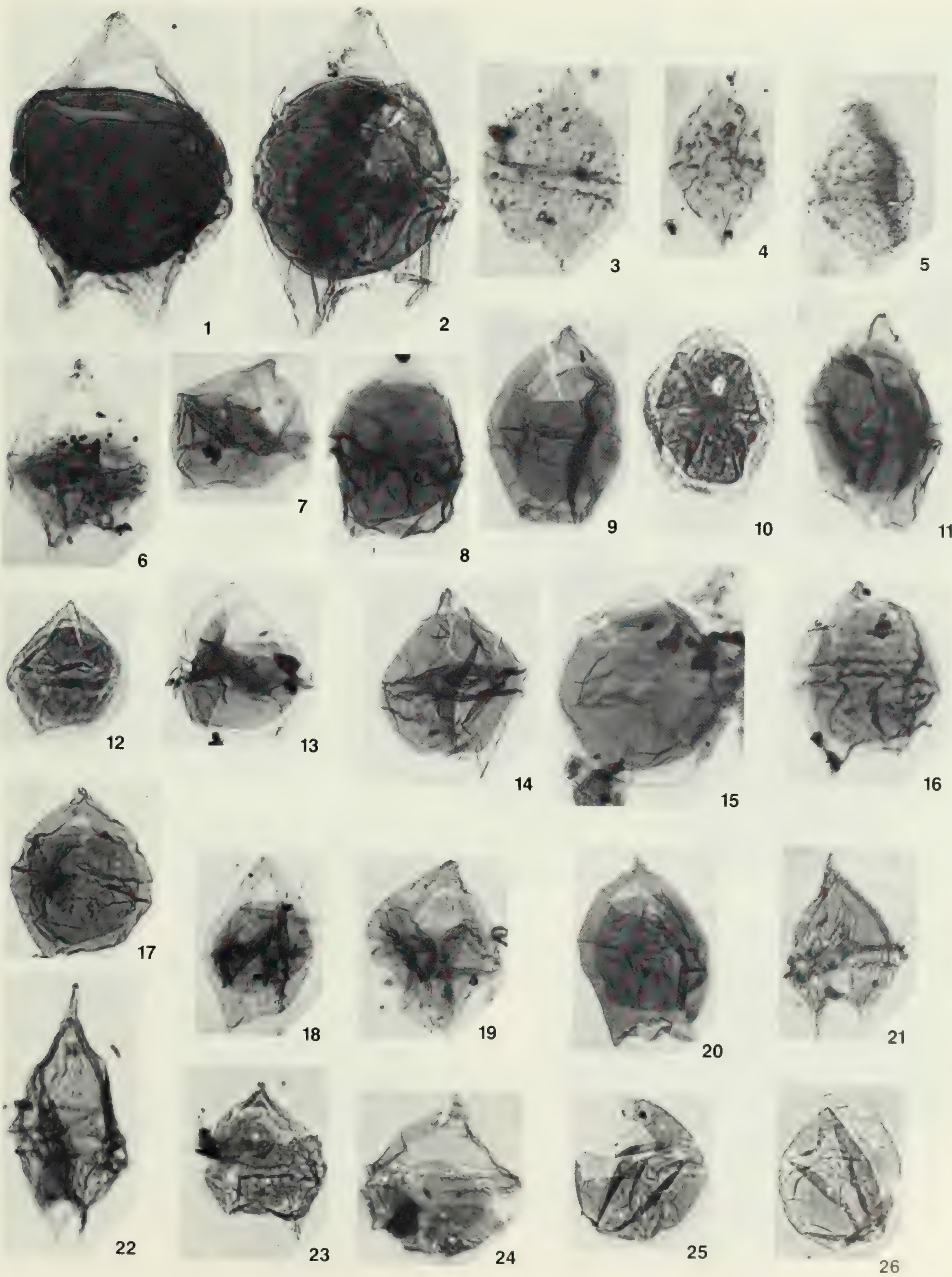
Plate 12, figs. 1-28.

All figures $\times 500$ unless otherwise stated.

Figs. 1-4. Trithyrodinium sabulum sp. nov., Kukebai Formation $\left(\mathrm{K}_{2} \mathrm{k}\right)$.

1. WG-13; $B_{1} ; 48.9 / 100.0$. Specimen showing the opercula (plates 1 to $\left.3 a\right)$ remaining attached $(\times 700)$.

2. Paratype, WG-13; $A_{1} ; 29.8 / 105.8$. Specimen showing the $3 \mathrm{I}$ archeopyle with $1 \mathrm{la}$ and $3 \mathrm{a}$ free, $2 \mathrm{a}$ remaining attached.

3. WG-18; $\mathrm{A}_{2} ; 43.5 / 101.2$

4. Holotype, WG-13; $B_{2} ; 39.1 / 107.2$. Specimen showing the opercular plates 1 to $3 a$ remaining attached $(\times 700)$

Figs. 5,6. Palaeocystodinium golzowense Alberti.

5. Bashibulake Formation ( $\left.\mathrm{E}_{3} \mathrm{~b}\right), \mathrm{WG}-77 ; \mathrm{A}_{4} ; 27.6 / 98.8$.

6. Wulagen Formation $\left(\mathrm{E}_{2} \mathrm{~W}\right), \mathrm{QF}-86 ; \mathrm{A}_{1} ; 45.0 / 100.4$.

7. Bellatudinium fusum Mao and $\mathrm{Yu}$, Wuyitake Formation $\left(\mathrm{K}_{2} \mathrm{~W}\right)$, WG-31; $\mathrm{A}_{2} ; 39.2 / 99.1$.

8. Luxadinium sp., Kukebai Formation ( $\left.\mathrm{K}_{2} \mathrm{k}\right)$, WG-24; $\mathrm{A}_{2} ; 40.8 / 114.8$.

Figs. 9-12. Palaeohystrichophora granulata sp. nov., Kukebai Formation $\left(\mathrm{K}_{2} \mathrm{k}\right)$.

9. Paratype, WG-13; $\mathrm{B}_{1} ; 47.5 / 104.0$

10. WG-13; $\mathrm{B}_{1} ; 38.8 / 104.8$.

11. Holotype, WG-13; $B_{1} ; 37.9 / 104.5$.

12. Wuyitake Formation $\left(\mathrm{K}_{2} \mathrm{~W}\right), \mathrm{SM}-60 ; \mathrm{A}_{3} ; 44.4 / 99.6$.

Figs. 13-16. Palaeohystrichophora infusorioides Deflandre, Kukebai Formation $\left(\mathrm{K}_{2} \mathrm{k}\right)$.

13. WG-13; $B_{1} ; 43.2 / 99.3$.

14. WG-13; $A_{7} ; 28.9 / 94.2$.

15. WG-18; $\mathrm{A}_{2} ; 46.8 / 96.2$. Specimen showing the archeopyle of (3I3P).

16. WG-18; $\mathrm{A}_{5} ; 41.1 / 112.3$.

17. Palaeoperidinium cretaceum Pocock, Wuyitake Formation $\left(\mathrm{K}_{2} \mathrm{~W}\right), \mathrm{SM}-60 ; \mathrm{A}_{2} ; 43.4 / 106.5$.

18. Palaeoperidinium sp. A, Qimugen Formation ( $\left.E_{1} q\right), Q F-43 ; A_{2} ; 45.8 / 97.5$.

19. Palaeoperidinium sp. B, Bashibulake Formation $\left(\mathrm{E}_{3} \mathrm{~b}\right)$, WG-74; $\mathrm{A}_{3} ; 37.2 / 108.3$.

Figs. 20,21. Subtilisphaera pirnaensis (Alberti) Jain and Millepied.

20. Yigeziya Formation $\left(\mathrm{K}_{2} \mathrm{y}\right)$, SM-60; $\mathrm{A}_{1} ; 41.4 / 98.2$.

21. Kukebai Formation $\left(\mathrm{K}_{2} \mathrm{k}\right)$, WG-13; $\mathrm{B}_{1} ; 41.7 / 110.3$.

22. Subtilisphaera scabrata Jain and Millepied, Kukebai Formation $\left(\mathrm{K}_{2} \mathrm{k}\right)$, WG-13; $\mathrm{B}_{2} ; 48.2 / 112.8$.

Figs. 23-25. Subtilisphaera senegalensis Jain and Millepied.

23. Kukebai Formation $\left(\mathrm{K}_{2} \mathrm{k}\right)$, WG-14; $\mathrm{A}_{1} ; 41.1 / 106.3$.

24. Yigeziya Formation $\left(K_{2} \mathrm{y}\right)$, SM-60; $\mathrm{A}_{2} ; 44.2 / 111.3$.

25. Kukebai Formation $\left(\mathrm{K}_{2} \mathrm{k}\right)$, WG-13; $\mathbf{B}_{1} ; 50.3 / 101.8$.

Figs. 26,27. Apectodinium paniculatum (Costa and Downie) Lentin and Williams, Wulagen Formation $\left(\mathrm{E}_{2} \mathrm{~W}\right)$.

26. QF-79; $A_{1} ; 9.5 / 106.2$.

27. QF-79; $\mathrm{A}_{1} ; 26.4 / 100.4$.

28. Kisselovia (?) clathrata (Eisenack) Lentin and Williams, Bashibulake Formation ( $\left.\mathrm{E}_{3} \mathrm{~b}\right), \mathrm{WG}-72 ; \mathrm{A}_{2}$; 25.0/103.7. 

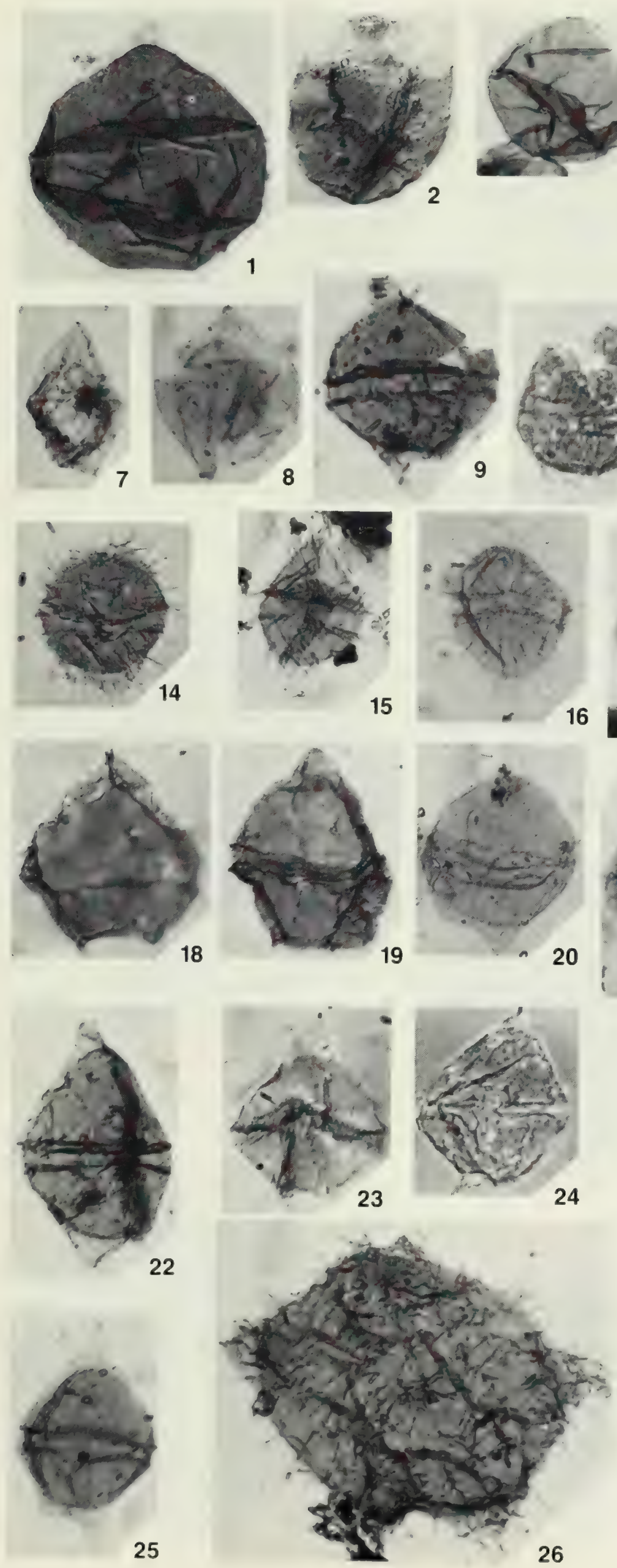
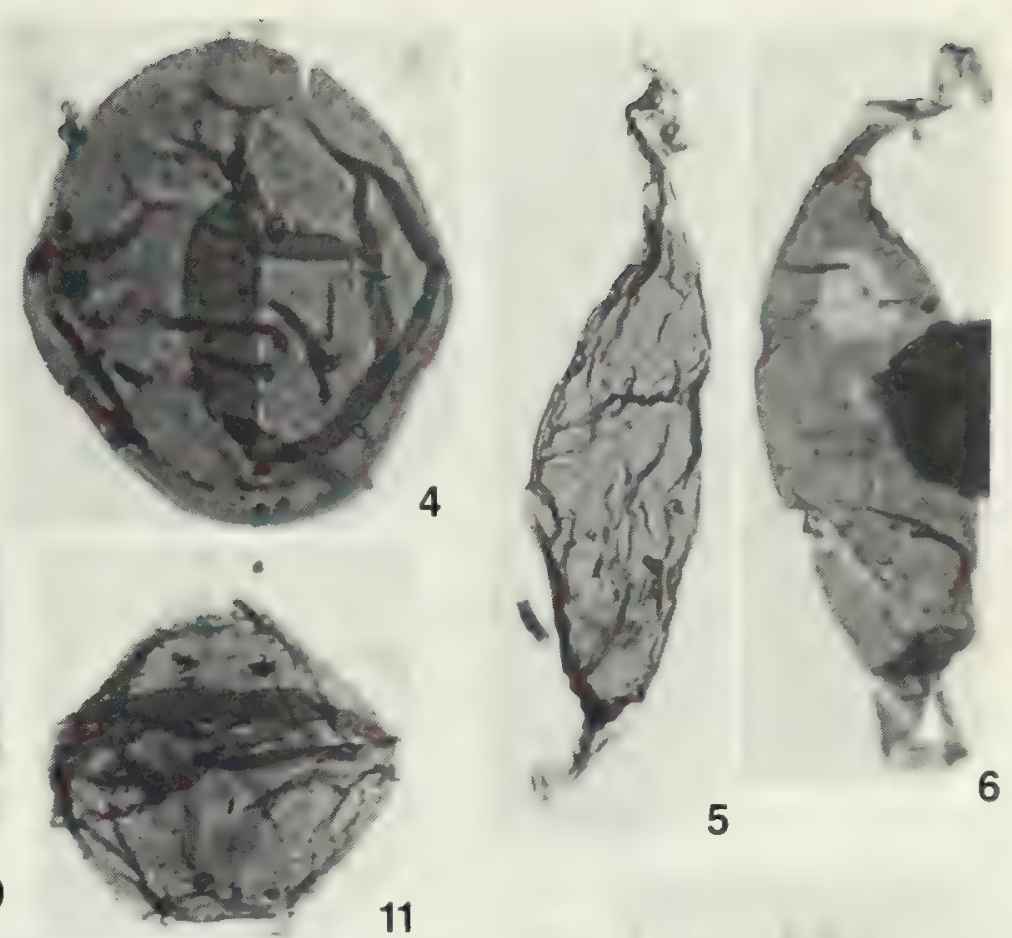

10
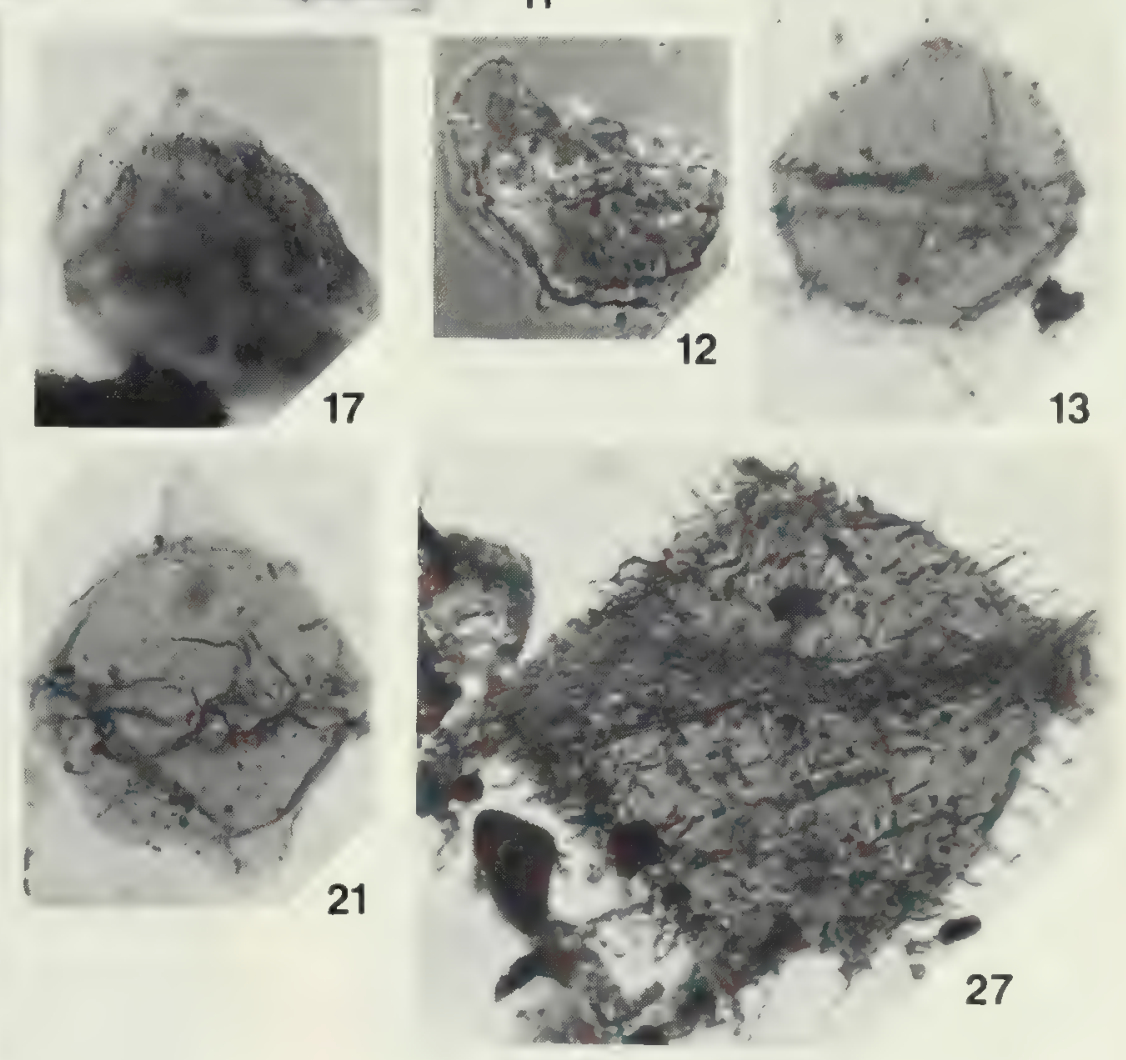

3

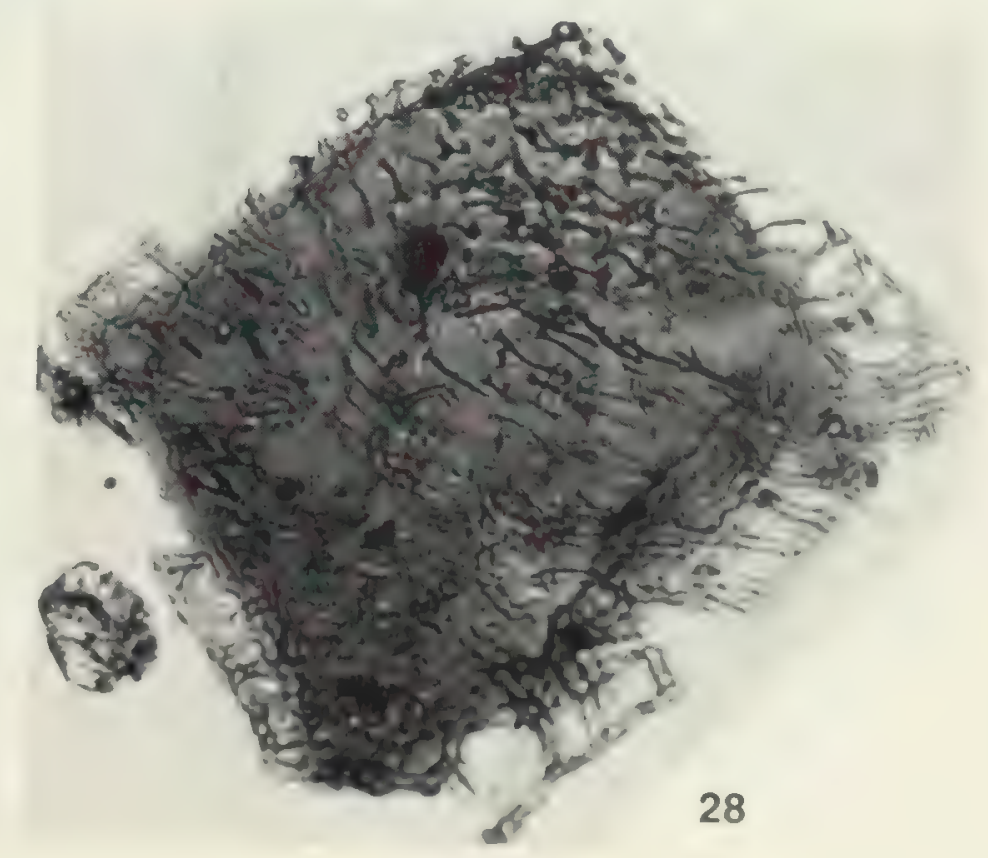


Plate 13, figs. 1-11.

All figures $\times 500$.

1. Kisselovia coleothrypta (Williams and Downie) Lentin and Williams, Bashibulake Formation ( $\left.\mathrm{E}_{3} \mathrm{~b}\right)$, WG-72; $A_{2} ; 25.0 / 103.7$.

Figs. 2-4. Kisselovia fusiformis sp. nov., Bashibulake Formation ( $\left.\mathrm{E}_{3} \mathrm{~b}\right)$.

2. Paratype, WG-77; $\mathrm{A}_{1} ; 48.0 / 95.3$.

3. Holotype, WG-77; $\mathrm{A}_{1} ; 28.6 / 97.6$.

4. WG-77; $A_{2} ; 50.5 / 102.2$.

Figs. 5-10. Kisselovia wulagenensis sp. nov., Wulagen Formation $\left(\mathrm{E}_{2} \mathrm{w}\right)$.

5. Paratype, WG-63; $A_{1} ; 29.4 / 94.5$.

6. Holotype, WG-63; $\mathrm{A}_{2} ; 35.3 / 101.6$.

7. Paratype, WG-63; $A_{5} ; 30.5 / 101.5$.

8. WG-63; A $_{5} ; 43.5 / 94.3$.

9. WG- $63 ; \mathrm{G}_{1} ; 28.0 / 93.8$.

10. WG- $63 ; \mathrm{G}_{3} ; 41.2 / 103.3$

11. Rhombodinium draco Gocht, Wulagen Formation ( $\left.\mathrm{E}_{2} \mathrm{~W}\right)$, QF-86; $\mathrm{A}_{4} ; 7.5 / 102.4$. 

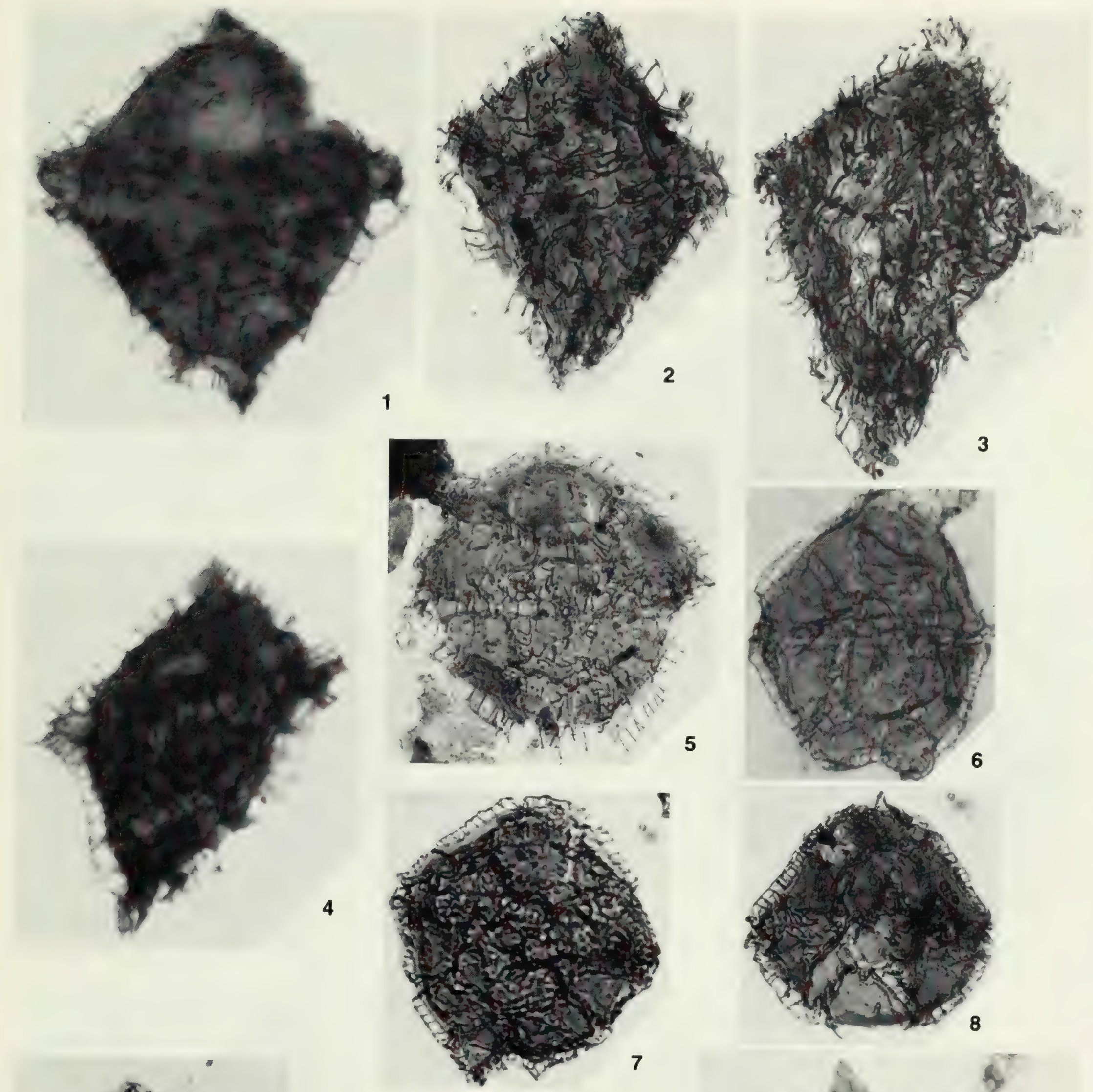

5
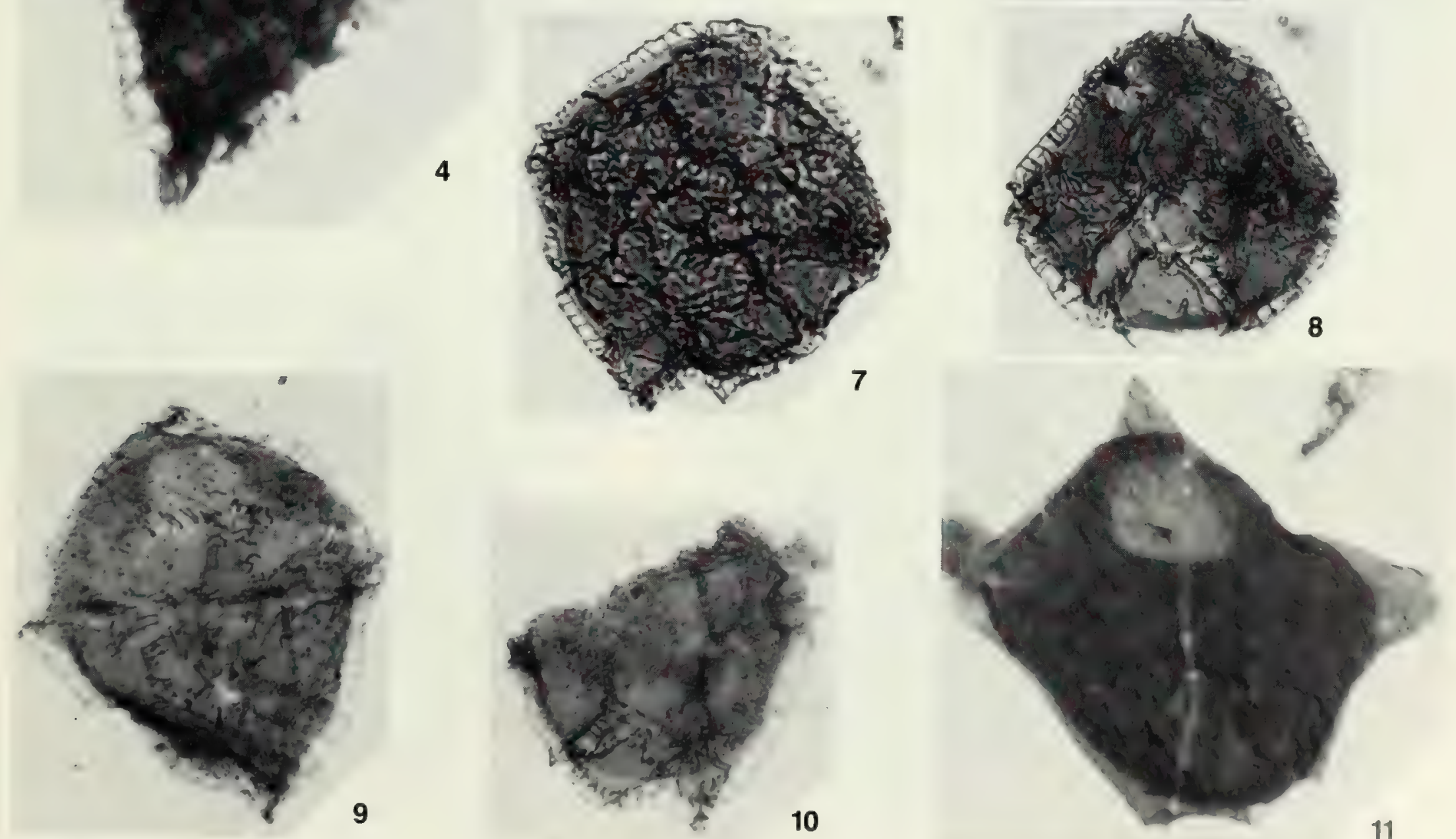
Plate 14, figs. 1-7.

All figures $\times 500$.

Figs. 1-3. Rhombodinium draco Gocht

1. Bashibulake Formation ( $\left.\mathrm{E}_{3} \mathrm{~b}\right), \mathrm{QF}-94 ; \mathrm{A}_{1} ; 47.2 / 98.9$.

2. Wulagen Formation $\left(\mathrm{E}_{2} \mathrm{~W}\right), \mathrm{QF}-86 ; \mathrm{A}_{3} ; 43.5 / 103.2$.

3. Bashibulake Formation ( $\left.\mathrm{E}_{3} \mathrm{~b}\right)$, WG-72; $\mathrm{A}_{1} ; 19.7 / 102.5$.

4. Rhombodinium longimanum Vozzhennikova, Bashibulake Formation ( $\left.\mathrm{E}_{3} \mathrm{~b}\right), \mathrm{WG}-72 ; \mathrm{A}_{2} ; 47.9 / 99.5$

Figs. 5,6. Wetzeliella articulata Eisenack, Bashibulake Formation ( $\left.\mathrm{E}_{3} \mathrm{~b}\right)$.

5. WG-72; $\mathrm{A}_{4} ; 49.0 / 93.0$.

6. WG-74; $A_{3} ; 36.6 / 101.8$.

7. Wetzeliella articulata Eisenack, Wulagen Formation $\left(\mathrm{E}_{2} \mathrm{~W}\right), \mathrm{WG}-63 ; \mathrm{G}_{2} ; 26.8 / 98.4$. 

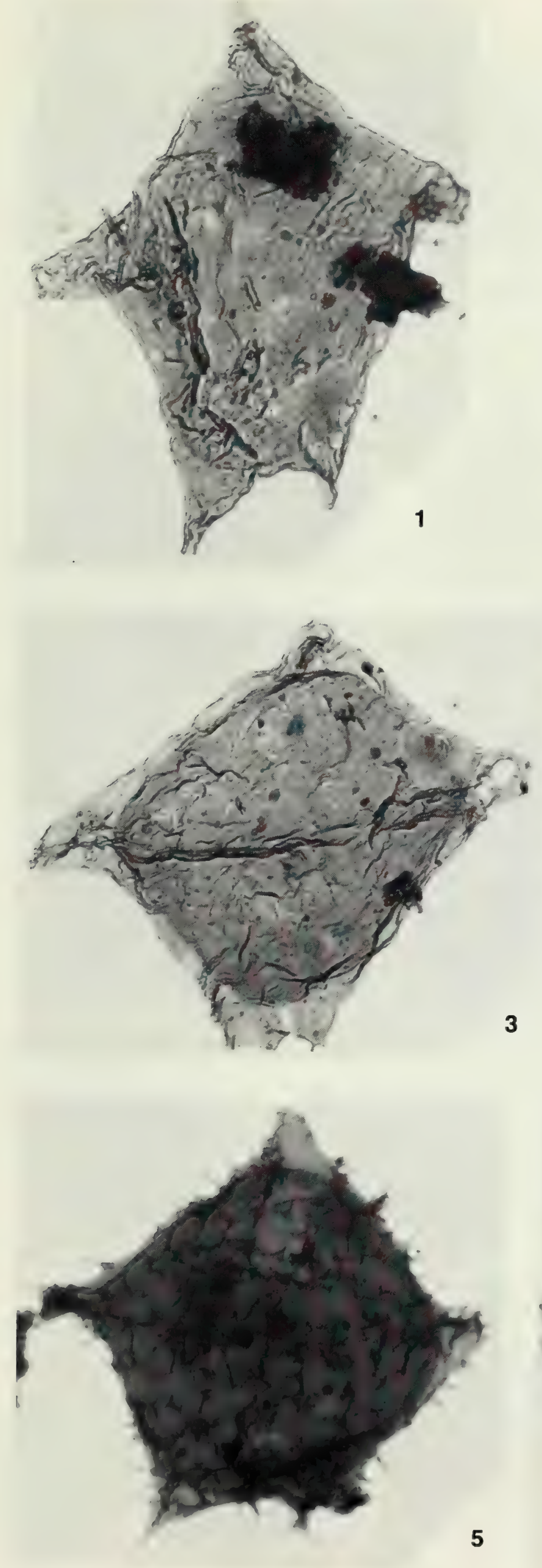
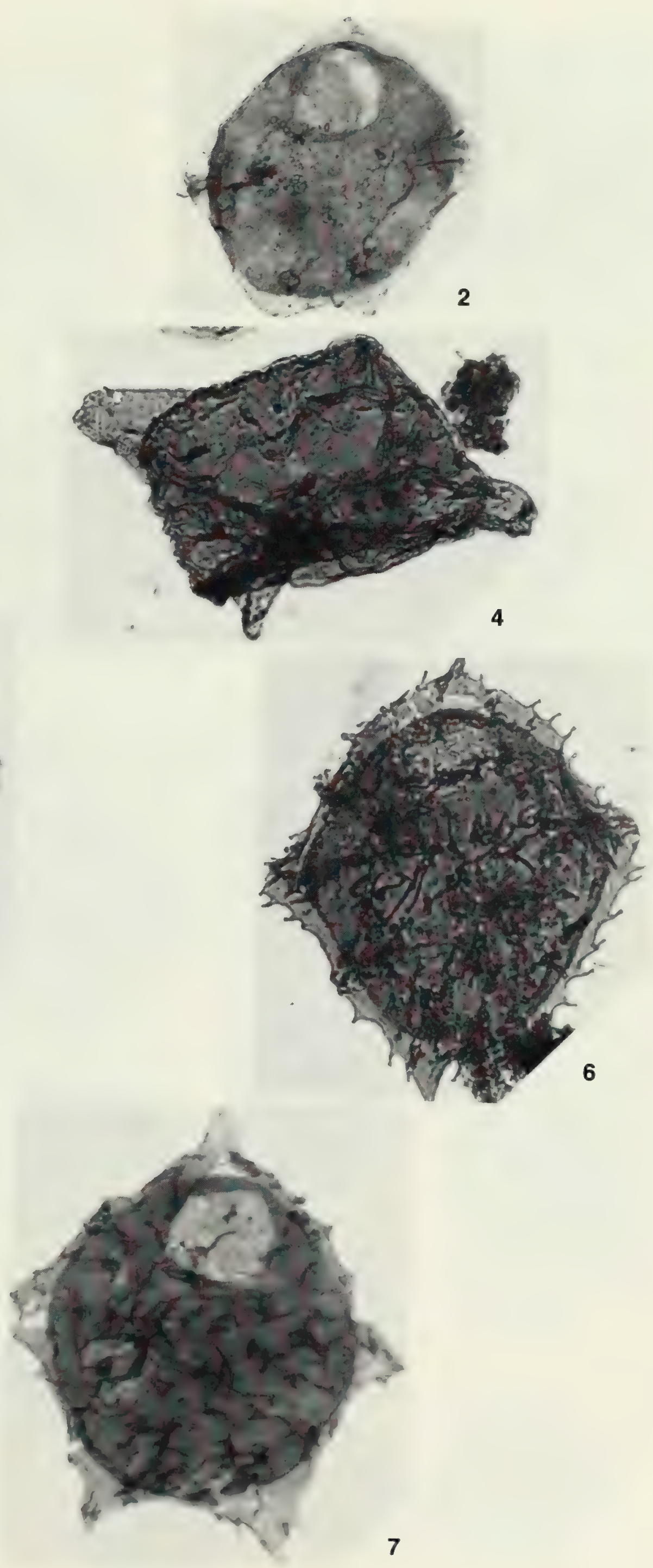
Plate 15, figs. 1-21.

All figures $\times 500$.

Figs. 1,2. Wetzeliella crassa sp. nov., Wulagen Formation $\left(\mathrm{E}_{2} \mathrm{w}\right)$.

1. Holotype, QF-79; $\mathrm{A}_{1} ; 45.0 / 101.7$.

2. Paratype, QF-79; $A_{1} ; 40.4 / 99.3$.

Figs. 3,4. Wetzeliella gochtii Costa and Downie, Bashibulake Formation $\left(\mathrm{E}_{3} \mathrm{~b}\right)$.

3. WG-72; $\mathrm{A}_{3} ; 52.5 / 100.6$.

4. WG-72; $\mathrm{A}_{1} ; 45.6 / 100.1$.

5. Wetzeliella hampdenensis Wilson, Bashibulake Formation ( $\left.\mathrm{E}_{3} \mathrm{~b}\right), \mathrm{WG}-72 ; \mathrm{A}_{2} ;$ 51.1/100.6.

Figs. 6,7. Wetzeliella sp. A, Wulagen Formation $\left(\mathrm{E}_{2} \mathrm{w}\right)$.

6. WG-63; $\mathrm{A}_{4} ; 35.4 / 102.4$.

7. WG-63; $A_{1} ; 27.6 / 100.3$.

Figs. 8-13. Talimudinium scissurum sp. nov.

8. Wuyitake Formation $\left(\mathrm{K}_{2} \mathrm{w}\right)$, SM-60; $\mathrm{A}_{2} ; 46.5 / 106.8$. Specimen with the operculum detached.

9. Yigeziya Formation $\left(\mathrm{K}_{2} \mathrm{y}\right)$, SM-60; $\mathrm{A}_{4} ; 42.5 / 108.8$.

10. Yigeziya Formation $\left(K_{2} y\right)$, paratype, $S M \cdot 60 ; A_{4} ; 39.9 / 109.5$.

11. The same specimen as fig. 10 , showing the low sutural ridges.

12. Yigeziya Formation $\left(\mathrm{K}_{2} \mathrm{y}\right)$, holotype, $\mathrm{SM}-60 ; \mathrm{A}_{4} ; 40.8 / 102.5$. Specimen with operculum free.

13. Kukebai Formation $\left(\mathrm{K}_{2} \mathrm{k}\right)$, WG-13; $\mathbf{B}_{1} ; 48.4 / 110.9$.

Figs. 14-16. Phelodinium anisos sp. nov., Qimugen Formation ( $\left.\mathrm{E}_{1 \mathrm{q}}\right)$.

14. Paratype, QF-47; $\mathrm{A}_{2} ; 26.8 / 96.5$. Specimen with the operculum attached.

15. QF-49; $\mathrm{A}_{1} ; 44.9 / 104.1$.

16. Holotype, QF-49; $A_{3} ; 43.0 / 107.7$.

17. Phelodinium pachyceras Liengjarern, Costa, and Downie, Bashibulake Formation ( $\left.\mathrm{E}_{3} \mathrm{~b}\right)$, WG-77; $\mathrm{A}_{1} ; 46.3 / 96.5$.

Figs. 18,19. Phelodinium pumilum Liengjarern, Costa, and Downie.

18. Bashibulake Formation ( $\left.\mathrm{E}_{3} \mathrm{~b}\right)$, WG-75; 48.4/106.9.

19. Wulagen Formation $\left(E_{3} W\right)$, QF-86; $A_{3} ; 47.4 / 103.0$.

Figs. 20,21. Lejeunecysta hyalina (Gerlach, emend. Kjellström) Artzner and Dörhöfer.

20. Wulagen Formation ( $\left.E_{2} W\right)$, WG-63; $A_{1} ; 32.2 / 97.9$.

21. Qimugen Formation ( $\left.E_{1} q\right)$, QF-49; $A_{3} ; 40.6 / 105.8$. 

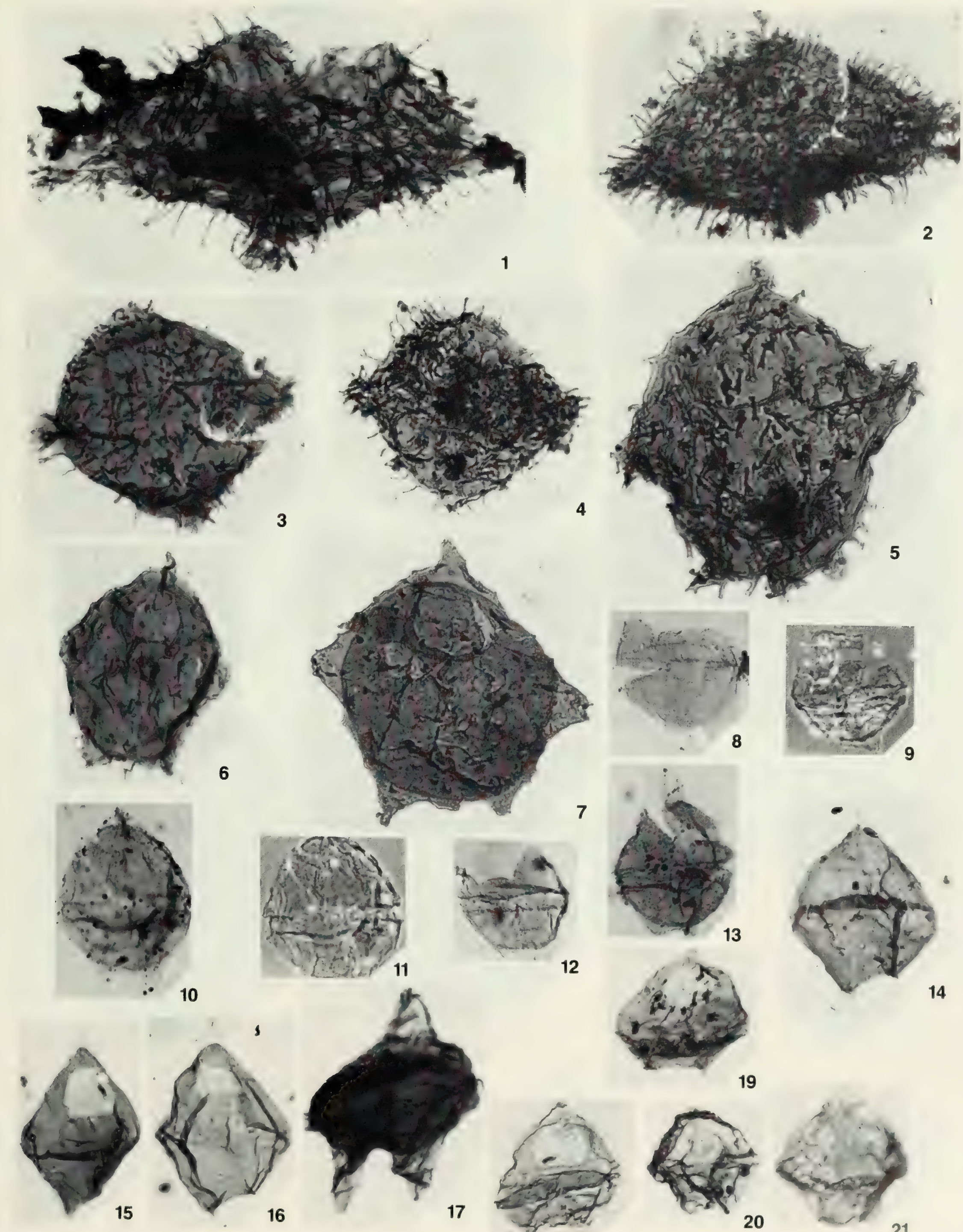

14

16
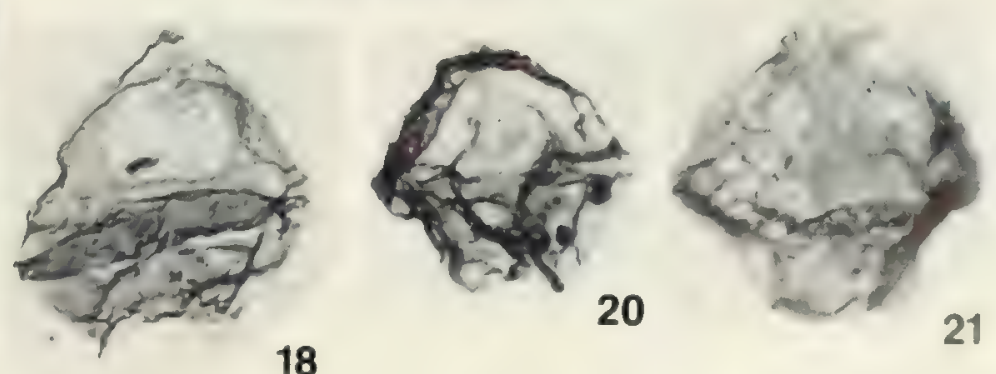
Plate 16, figs. 1-25.

All figures $\times 500$.

1. Lejeunecysta sp., Qimugen Formation ( $\left.\mathrm{E}_{1} \mathrm{q}\right), \mathrm{QF}-43 ; \mathrm{A}_{2} ; 43.0 / 106.3$.

Figs. 2,3. Sumatradinium hispidum (Drugg) Lentin and Williams, Wulagen Formation $\left(\mathrm{E}_{2} \mathrm{w}\right)$.

2. WG-63; $\mathrm{A}_{2} ; 39.7 / 97.6$.

3. WG-63; $A_{2} ; 40.2 / 101.0$.

Figs. 4-6. Pseudoalterbia concinna sp. nov., Kukebai Formation $\left(\mathrm{K}_{2} \mathrm{k}\right)$.

4. Holotype, WG-18; $A_{2} ; 46.0 / 97.2$. Ventral view.

5. Paratype, WG-18; $A_{5} ; 43.7 / 95.5$. Ventral view.

6. WG-18; $A_{2} ; 49.2 / 106.8$. Ventral view, specimen with operculum hinged.

Figs. 7-11. Xuidinium laevigatum sp. nov., Qimugen Formation ( $\left.\mathrm{E}_{1} \mathrm{q}\right)$.

7. Paratype, QF-43; $A_{4} ; 18.3 / 102.8$. Specimen showing the operculum falling inside the cyst cavity.

8. SM-77; $\mathrm{A}_{2} ; 38.0 / 96.7$. Specimen with opercular plates 1 to $3 \mathrm{a}$ attached.

9. QF-43; $A_{4} ; 40.3 / 104.6$. Specimen with operculum (2a) attached.

10. Holotype, SM-77; $A_{1} ; 39.7 / 101.8$.

11. Paratype, $\mathrm{QF}-43 ; \mathrm{A}_{2} ; 43.6 / 98.7$. Two specimens showing the operculum inside the cyst cavities.

12. Thalassiphora bononiensis Corradini, Wulagen Formation ( $\left.E_{2} w\right)$, WG-63; $A_{1} ; 34.9 / 101.0$.

13. Thalassiphora delicata Williams and Downie, Wulagen Formation $\left(\mathrm{E}_{2} \mathrm{~W}\right), \mathrm{QF}-86 ; \mathrm{A}_{3} ; 53.2 / 111.7$.

14. Thalassiphora patula (Williams and Downie) Stover and Evitt, Bashibulake Formation ( $\mathrm{E}_{3} \mathrm{~b}$ ), QF-94; $\mathrm{A}_{2} ; 52.1 / 109.0$.

Figs. 15,16. Thalassiphora pelagica (Eisenack) Eisenack and Gocht, Wulagen Formation $\left(\mathrm{E}_{2} \mathrm{w}\right)$.

15. WG-63; $\mathrm{A}_{2} ; 26.1 / 98.5$.

16. WG- $63 ; \mathrm{A}_{2} ; 38.5 / 100.8$.

17. Fromea staveia Elsik, Bashibulake Formation ( $\left.E_{3} b\right)$, WG-70; $A_{9} ; 39.0 / 106.7$.

Figs. 18,19. Granodiscus granulatus Mädler.

18. Bashibulake Formation ( $\left.\mathrm{E}_{3} \mathrm{~b}\right), \mathrm{WG}-70 ; \mathrm{A}_{8} ; 47.3 / 104.0$.

19. Wuyitake Formation $\left(\mathrm{K}_{2} \mathrm{~W}\right)$, WG-31; $\mathrm{A}_{2} ; 40.4 / 97.7$.

Figs. 20,21. Leiosphaeridia hyalina (Deflandre) Downie.

20. Kukebai Formation ( $\left.\mathrm{K}_{2} \mathrm{k}\right)$, WG-20; $\mathrm{A}_{4} ; 45.5 / 96.4$.

21. Bashibulake Formation ( $\left.E_{3} b\right), W G-77 ; A_{3} ; 46.5 / 109.0$

Figs. 22,23. Micrhystridium sp. cf. M. castanium Valensi, Qimugen Formation $\left(\mathrm{E}_{1} \mathrm{q}\right)$.

22. QF-43; $\mathrm{A}_{2} ; 39.8 / 108.5$.

23. QF-43; $\mathrm{A}_{2} ; 51.4 / 104.6$.

24. Pterospermella harti (Sarjeant) Eisenack, Kukebai Formation $\left(\mathrm{K}_{2} \mathrm{~K}\right)$, WG-20; $\mathrm{A}_{4} ; 42.5 / 104.5$.

25. Pterospermella australiensis (Deflandre and Cookson) Eisenack, Kukebai Formation $\left(\mathrm{K}_{2} \mathrm{k}\right)$, WG-13; $\mathrm{A}_{1} ; 32.3 / 99.0$. 

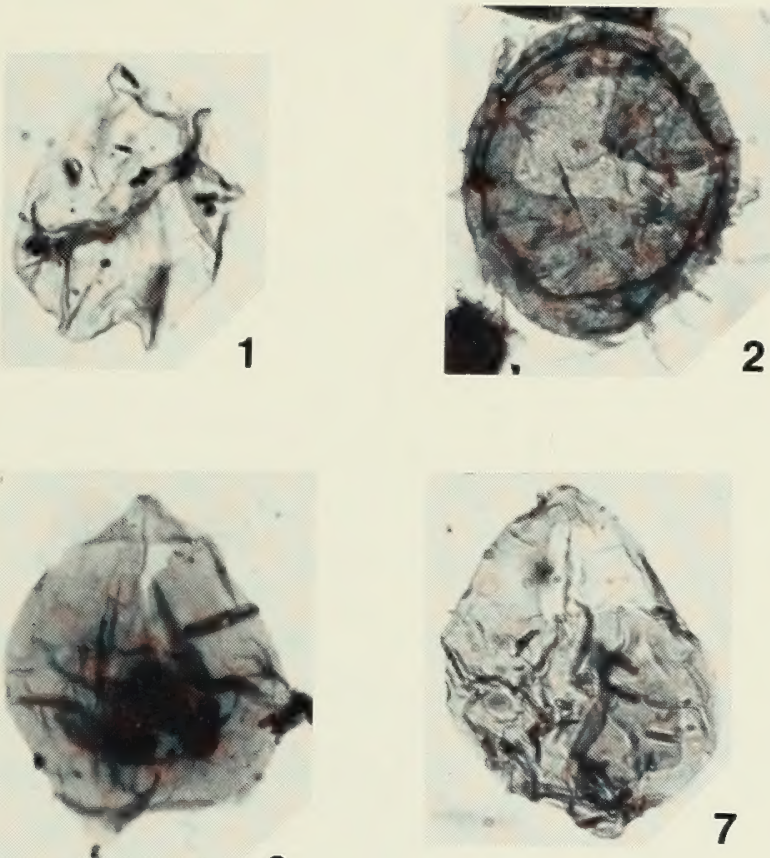

6
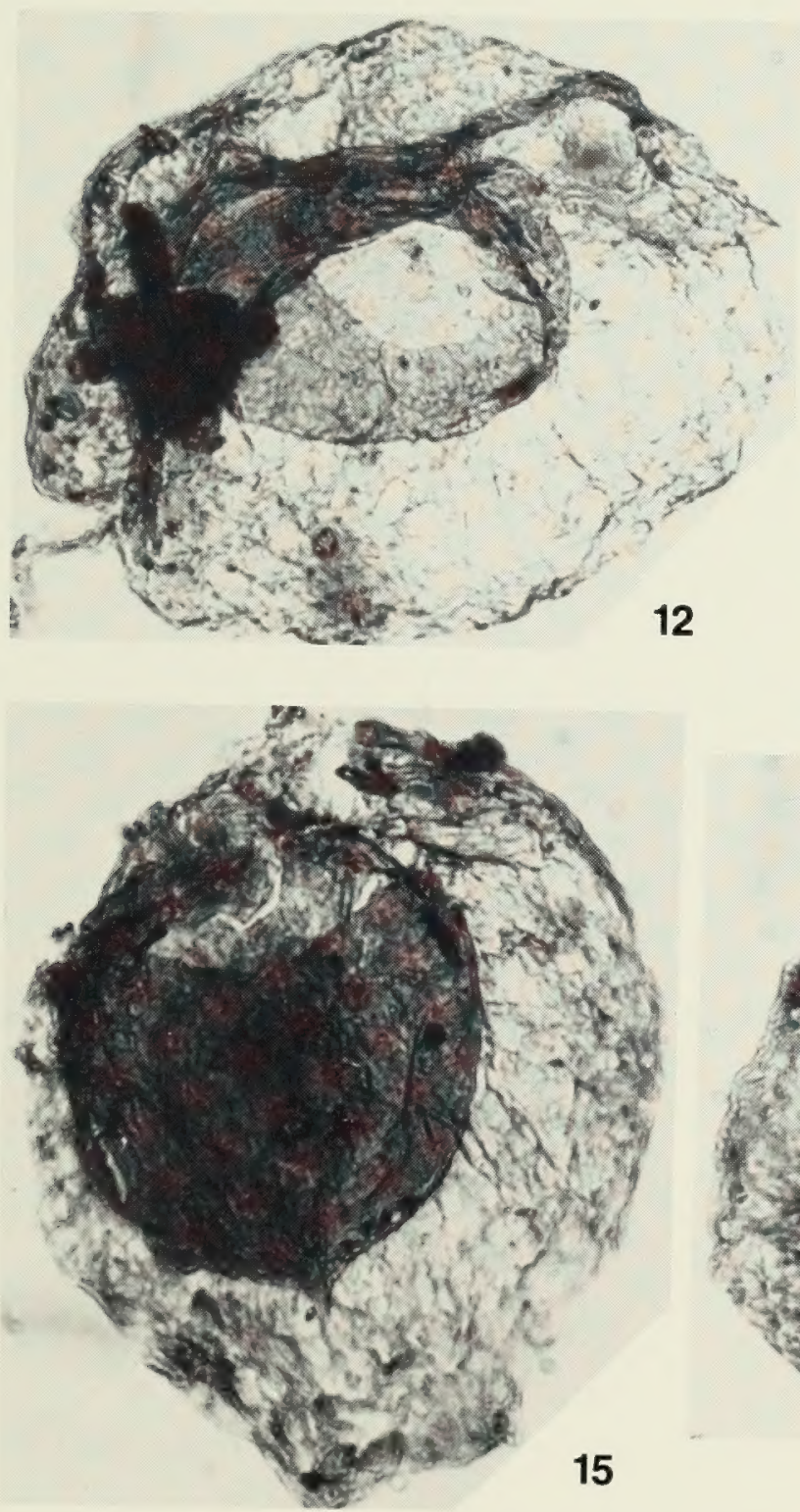

15

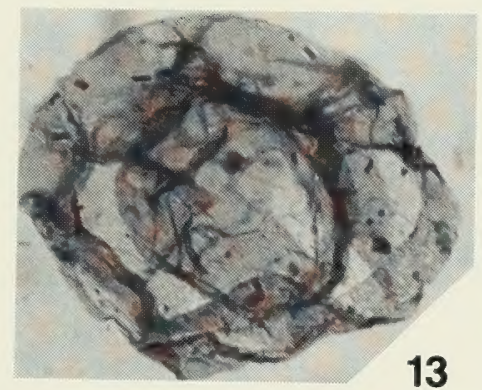

13
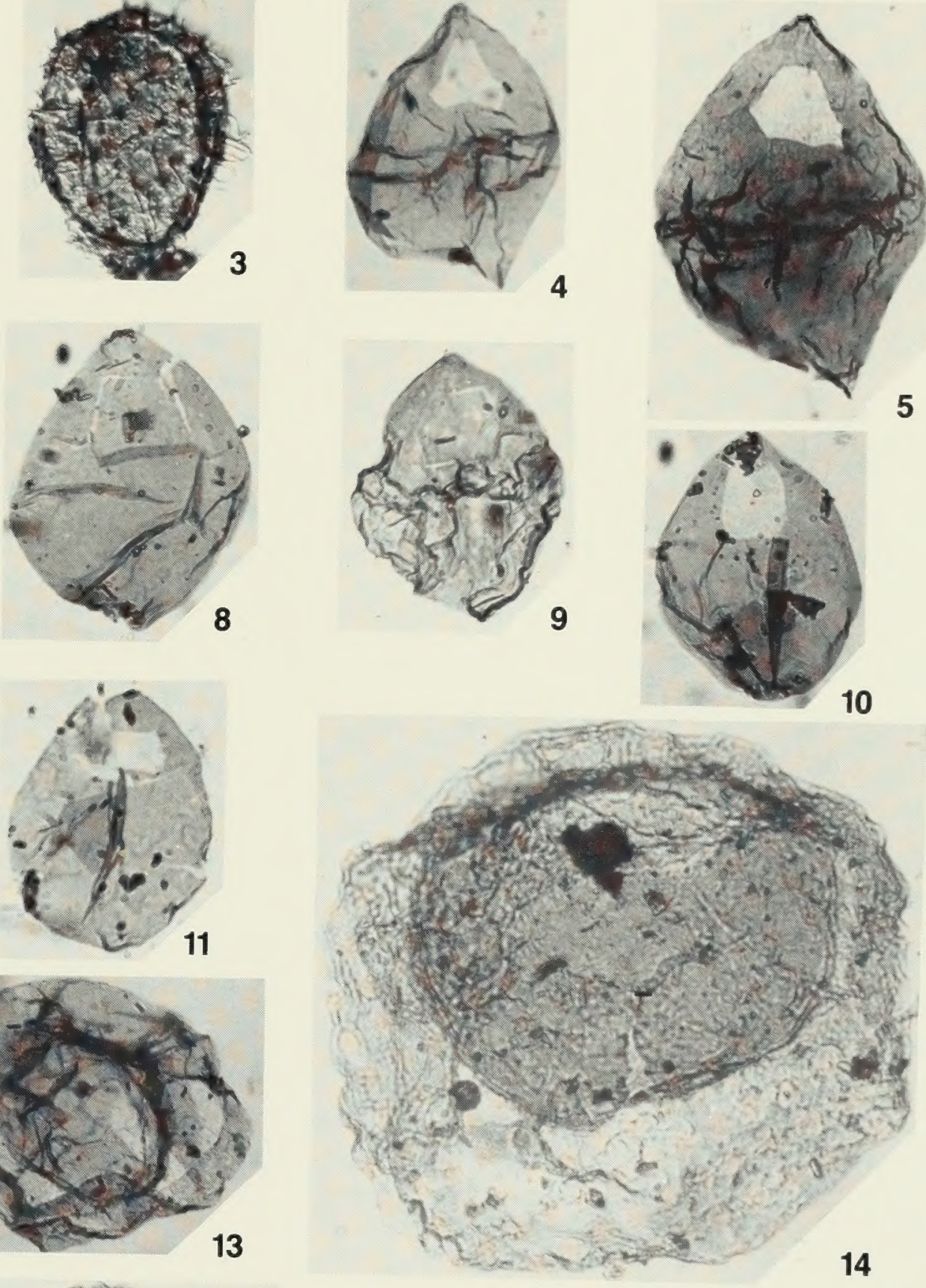

14
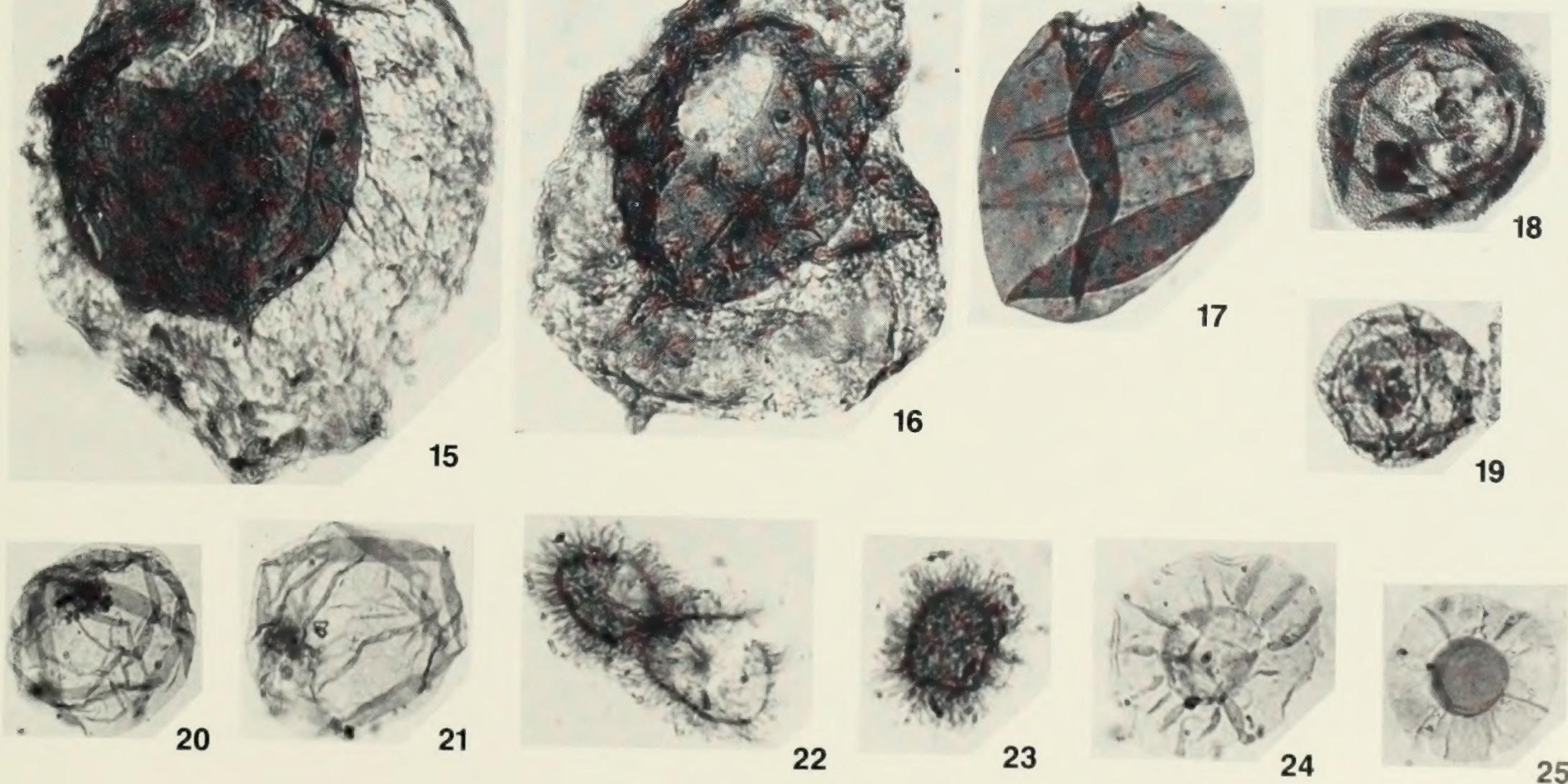




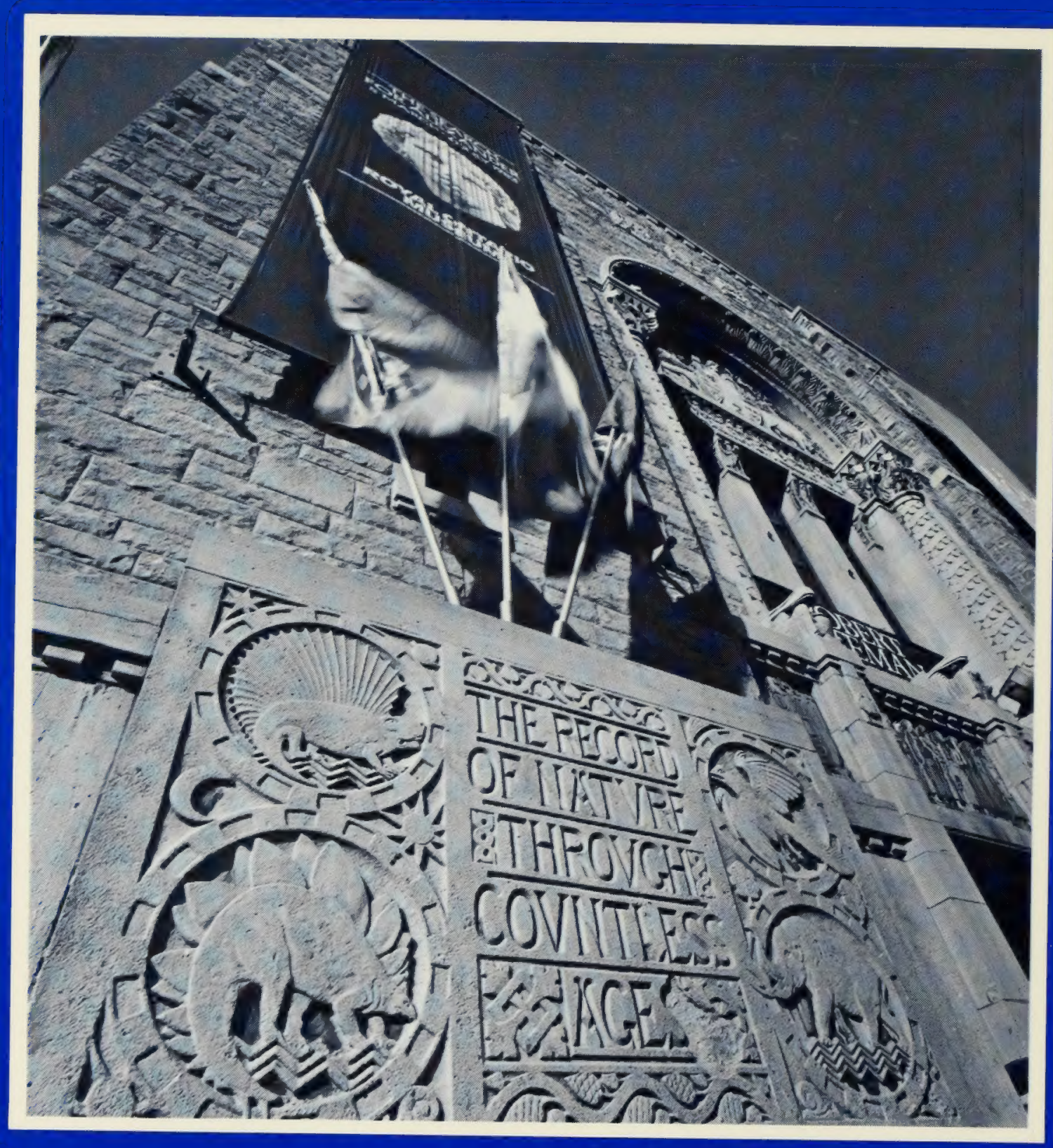

ISBN 0-88854-334-4

ISSN 0384-8159 